Hudson-Fulton Celebration Commission

\author{
The New York Botanical Garden \\ Bronx Park
}

\title{
Descriptive Guide
}

to the

Grounds, Buildings and Collections

\section{Native Trees of the Hudson River Valley}

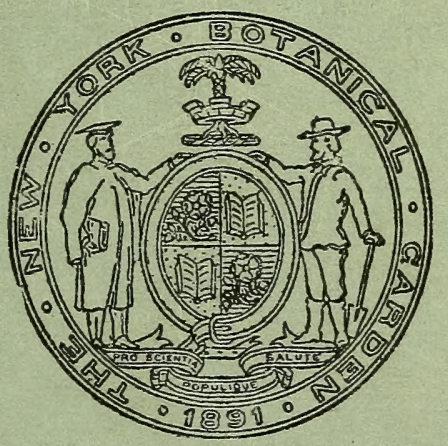

NEW YORK

September, 1909

Price .. 25 Cents 


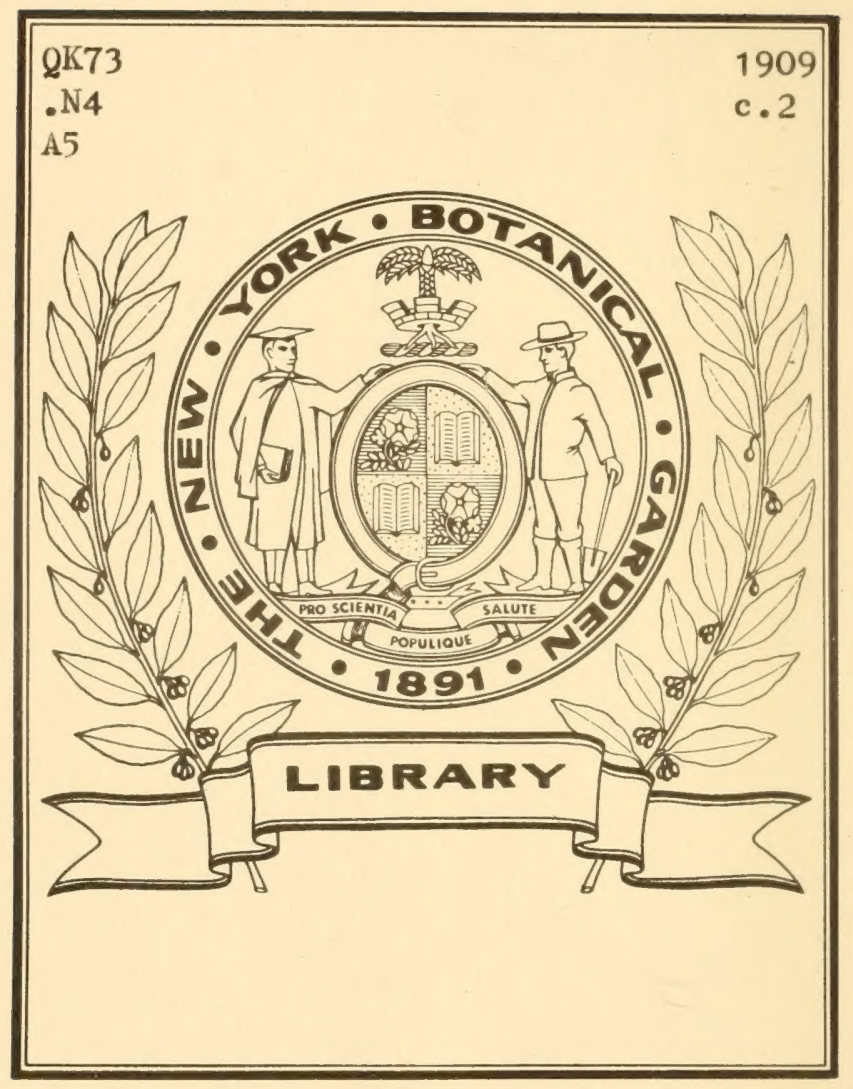






\title{
HUDSON-FULTON CELEBRATION COMMISSION
}

\author{
THE NEW YORK BOTANICAL GARDEN \\ BRONX PARK
}

\section{Descriptive Guide}

TO THE

\section{Grounds, Buildings and Collections}

\section{Native Trees of the Hudson River Valley}

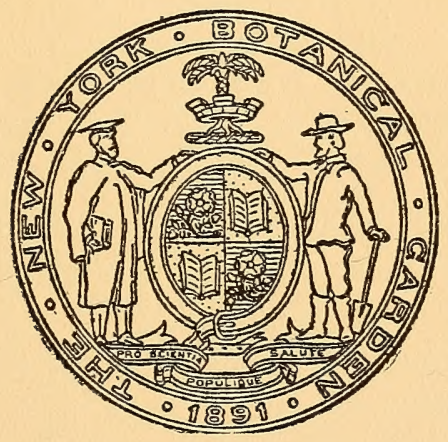

Reprinted from the

Bulletin of the New York Botanical Garden, No. 23, with an index added

NEW YORK

SEPTEMBER, I $9 \circ 9$ 
$\frac{45}{1909}$ 


\section{TheHudson-Fulton Celebration Commission}

\section{Appointed by the Governor of the State of New York and the Mayor of the City of New York and chartered by Chap- ter 325, Laws of the State of New York, 1906}

\section{LIST OF OFFICERS \\ President}

Gen. Stewart L. WOODFORD

Presiding Vice-President

Mr. Herman Ridder

Vice-Presidents

Mr. Andrew Carnegie Hon. Joseph H. Choate Maj.-Gen. F. D. Grant, U. S. A. Hon. Seth Low

Mr. J. Pierpont Morgan

Hon. Levi P. Morton

Hon. Alton B. Parker
Mr. John E. Parsons

Gen. Horace Porter

Hon. Frederick W. Seward

Mr. Francis Lynde Stetson

Hon. Oscar S. Straus

Mr. Wm. B. Van Rensselaer

Gen. Jas. Grant Wilson

\section{Treasurer}

Mr. IsaAc N. SELIGMAN

No. I William Street, New York

Secretary

Mr. Henry W. SacketT
Assistant-Secretary

Mr. Edward Hagaman Hall

Art and Historical Exhibits Committee

Mr. J. Pierpont Morgan, General Chairman

Sub-Committee in

Charge of Scientific and Historical Exhibits

Dr. Grorge F. Kunz, Chairman

401 Fifth Avenue, New York

Mr. Samuel V. Hoffman

Mr. Archer M. Huntington
Prof. Henry Fairfield Osborn Mr. Philip T. Dodge

\section{Sub-Committee in}

Charge of Arts Exhibits

Hon. RobT. W. DE Forest, Chairman

Metropolitan Museum of Art

Sir. Caspar Purdon Clarke

Dr. Edward Robinson
Mr. George F. Hearn

Dr. George F. Kunz

Headquarters: Tribune Building, New York

Telephones: BeEkman 3097 and 3098

Western Union Cable Address: "Hudfulco" 


\section{List of Institutions holding Exhibitions under the auspices of or in cooperation with Scientific, Historical and Art Committees of the Hudson-Fulton Celebration Commission}

AMERICAN MUSEUM OF NATURAL HISTORY, Seventy-seventh Street, from Columbus Avenue to Central Park West. Open daily, except Sundays, from 9 a.m. to 5 p.m. Sundays from I to 5 p.m. Always free. Special Exhibition during the Hudson-Fulton Celebration, from September Ist to December Ist. Original objects showing the life and habits of the Indians of Manhattan Island and the Hudson River Valley. (Special illustrated catalogue for sale, price ro cents.)

Take Sixth or Ninth Avenue Elevated Railway to Eighty-first Street, or Subway to Seventy-ninth Street; also reached by all surface cars running through Columbus Avenue or Central Park West.

AMERICAN SOCIETY OF MECHANICAL ENGINEERS, Engineering Building, 29 West Thirty-ninth Street. Robert Fulton Exhibition. Consists of paintings, drawings, books, decorations and furniture, and working models of John Fitch's steamboat, the first boat operated and propelled by steam; Robert Fulton's "Clermont," the first successful application of steam to navigation, and John Stevens' "Phœnix," the first steamboat to sail on the ocean.

The exhibition will be shown in the Council Room of the Society, on the eleventh floor, and will be open from 9.00 a.m. until 5.30 p.m. during the entire period of the Hudson-Fulton Celebration, and from 9.00 a. m. until 5.00 p.m. daily until December 6th.

BROOKLYN INSTITUTE, Eastern Parkway. Open daily, except Sundays, from 9 a.m. to 6 p.m.; Sundays from 2 to 6 p.m. Thursday evenings from 7.30 to 9.30 p.m. Free except on Mondays and Tuesdays, when admission fee is charged of 25 cents for adults and ro cents for children under six years of age. Collection illustrating various departments of Archæology, Mineralogy and Ethnography. Special Exhibition relating to past and present life of Indians on Long Island. Portrait of Robert Fulton painted by himself, the property of Col. Henry T. Chapman and loaned by him to the Museum. Open September Ist to December 3Ist. (Illustrated catalogue for sale.)

Take Subway Express to Atlantic Avenue, or Flatbush Avenue Trolley from Brooklyn Bridge. St. John's Place surface car from Atlantic Avenue or Borough Hall.

CHILDREN'S MUSEUM (Brooklyn Institute), Bedford Park, Brooklyn Avenue. Collection illustrative of the fauna of Long Island. Open free to the public from Monday to Saturday (inclusive) from 9 a.m. to 5.30 p.m., and on Sunday from 2 until 5.30 p.m.

CITY HISTORY CLUB OF NEW YORK, 2r West Forty-fourth Street. Special Exhibition of Illustrations, Photographs, Maps and Plans, relating to the history of the City of New York, and all of the originals used in the City History Club Historical Guide Book of the City of New York.

COLLEGE OF THE CITY OF NEW YORK, St. Nicholas Avenue and 139th Street. Hudson-Fulton Exhibit. During the Hudson-Fulton Celebration and for some weeks thereafter, the College of the City of New York will have on exhibition in its historical museum a collection of charts, views, manuscripts and relics representing old New 
York. Among the charts will be original prints of New Netherlands and New Amsterdam by Nicholas J. Vischer, about 1650; N. Visscher, 1690; Lotter's "New Jorck," I720; contemporary plans and views of the Revolutionary period showing the movements of Washington and Howe in this vicinity during the Campaign of 1776 ; Revolutionary battle relics; portraits, residences and letters of old New Yorkers; bronze busts of Washington, Lincoln and Fulton by Houdon and Volk; and other material suggested by the celebration.

Take Sixth Avenue Elevated Railway to I $_{4}$ oth Street, or Broadway Subway to One Hundred and Thirty-seventh Street.

DEPARTMENT OF PARKS, BOROUGH OF BROOKLYN. Through the courtesy of Commissioner Michael J. Kennedy and his assistant arboriculturist, J. J. Levison, the different species of trees have been labeled in Prospect Park, from the Plaza to the Willink Entrance; in Bedford Park; in Highland Park, and in Tompkins Park. An additional small enameled sign has been hung on those labeled trees that were indigenous to the Hudson River Valley in I6og. The special label reads: "This species is a native of the Hudson River Valley."

FRAUNCES TAVERN, 54 Pearl Street, near Broad Street. Historic Revolutionary Building. Built in I7Ig. Scene of Washington's farewell to his officers on December 4, I783. Restored December 4, I907, by the New York Society of the Sons of the Revolution. Open daily, except Sundays, from 9 a.m. to 6 p.m. Special Exhibition of Revolutionary Relics by the New York State Society of the Sons of the Revolution, who are the owners of that historical building, September $5^{\text {th }}$ to November Ist.

Take Subway to Bowling Green Station, or Third Avenue Elevated Railway to Hanover Square Station, or Broadway surface cars.

LONG ISLAND HISTORICAL SOCIETY, corner of Pierrepont and Clinton Streets, Brooklyn, between Brooklyn Bridge and Borough Hall. Open daily, except Sundays, from 8.30 a.m. to 6 p.m. Reference library of 70,000 volumes; manuscripts, relics, etc. Autograph receipt of Robert Fulton and original manuscript volume of Danker's and Sluyter's "Journal of a Voyage to New York in I679-80."

Take Subway to Borough Hall, Brooklyn; Third Avenue Elevated Railway to Brooklyn Bridge, connecting with Bridge cars; or surface cars to Bridge.

METROPOLITAN MUSEUM OF ART, Central Park East. Main entrance on Fifth Avenue at Eighty-second Street. Open daily, except Sundays, from ro.00 a.m. to 6.00 p.m.; in winter to 5.00 p. m.; Saturdays to Io.00 p.m.; Sundays from r.00 to 6.00 p.m. On Mondays and Fridays an admission fee of 25 cents is charged, except to members and copyists. Collections illustrating all departments of Art and Archrology. Special Exhibition of a magnificent Collection of over I30 of the works of Old Dutch Masters, constituting the finest Exhibition of this kind ever made. Products of Colonial Art: Industrial Art, Furniture, Pewter of the I 7 th and I8th centuries, etc. (Two illustrated catalogues for sale, one of Dutch Exhibit and one of Colonial Arts; price ro cents each. Also finely illustrated edition de luxe.)

Take Fifth Avenue stages or Madison Avenue surface cars to Eighty-second Street, one block east of Museum; connection with Subway at Forty-second Street, and with Elevated Railway and West Side surface cars at Fifty-ninth Street.

NATIONAL ARTS CLUB, Twentieth Street near Irving Place (Gramercy Park). This house was formerly the residence of Samuel J. Tilden, and is situated one block east of the birth-place of Ex-President Roose- 
velt. Open daily from September 20th to about October 18th, 1909, from 9 a.m. to ro p.m. Special Loan Exhibition by the National Arts Club, in cooperation with the American Scenic and Historic Preservation Society, under the management of the New York Zoological Society.

Three centuries of New York City: Special Exhibition of Paintings, Photographs, Drawings and other interesting materials, illustrating the growth and progress of New York from the time of Henry Hudson to the present day. (Catalogue for sale.)

Take Fourth or Madison Avenue surface cars to corner of Fourth Avenue and Twentieth Street, one block west of Club-house. Subway Station at Eighteenth Street and Fourth Avenue, three blocks away.

NEW YORK AQUARIUM, in Battery Park. Open daily, including Sundays, from 9 a.m. to 5 p.m. until October 15 th. (October r6th to April r 4 th, from ro a.m. to 4 p.m.) This building was erected in 1807 by the United States Government as a fort and after the War of 1812 was called Castle Clinton; later, as Castle Garden, it was the scene of Jenny Lind's triumphs and from 1855 to 1890 it was the portal of the New World for $7,690,606$ immigrants. This is the largest aquarium in the world and contains a greater number of specimens and species than any other. All tanks containing fish indigenous to the Hudson River will be so marked.

Take Elevated Railway to Battery Place Station, or Subway to Bowling Green Station; also reached by all surface cars which go to South Ferry.

NEW YORK BOTANICAL GARDEN, Bronx Park. Museums open daily, including Sundays, from ro a.m. to 5 p.m.; Conservatories from ro a.m. to 4 p.m. Grounds always open. In the Grounds and Conservatories exhibits of Plants, Shrubs, Trees, and Natural Woodland; in the Museums, Plant Products utilized in the Arts, Sciences and Industries. All trees growing on Manhattan Island and in the Hudson River Valley at the time of Hudson's arrival are marked with the letter " $H$." (Special illustrated catalogue for sale.)

Take Third Avenue Elevated Railway to Bronx Park (Botanical Garden). Subway passengers change at 149 th Street; also reached by Harlem Division of the New York Central Railroad from Grand Central Station, Fourth Avenue and Forty-second Street.

NEW YORK GENEALOGICAL AND BIOGRAPHICAL SOCIETY, 226 West Fifty-eighth Street, between Broadway and Seventh Avenue. Open daily, except Sundays, from ro.00 a.m. to 5.00 p.m., until November rst. Special Exhibition of old Deeds, Manuscripts, Books, Portraits, etc., relating to the history of the United States up to and including the War of I8I2. (Catalogue for sale.)

Take Broadway surface cars to corner of Fifty-eighth Street. Subway station at Columbus Circle (Fifty-ninth Street), two blocks distant; Sixth Avenue Elevated station at Ninth Avenue and Fifty-ninth Street, three blocks away.

NEW YORK HISTORICAL SOCIETY, corner of Seventy-seventh Street and Central Park West. September 25 th to October 3 oth, open daily from 9 a.m. to 5 p.m. Robert Fulton Exhibition of the New York Historical Society, in cooperation with the Colonial Dames of America. (Catalogue for sale.)

Take Sixth Avenue Elevated Railway to Eighty-first Street and Columbus Avenue, or surface cars traversing Central Park West; also reached by any Columbus Avenue surface car to Seventy-seventh Street.

NEW YORK PUBLIC LIBRARY, Lenox Branch, Fifth Avenue and Seventy-second Street. Open daily, except Sundays, from 9 a. m. to 6 p.m. 
Special Exhibition of Prints, Books, Manuscripts, etc., relating to Henry Hudson, the Hudson River, Robert Fulton, and Steam Navigation. (Special illustrated catalogue for sale; price ro cents.)

Take Fifth Avenue Stages, or Madison Avenue surface cars to Seventysecond Street, one block east of Library; connection with Subway at Grand Central Station and with Elevated Railway and West Side surface cars at Fifty-ninth Street.

NEW YORK ZOOLOGICAL PARK, under the management of the New York Zoological Society, in Bronx Park. Open daily, including Sundays, from 9 a.m. until an hour before sunset (November $\mathbf{I}$ to May $\mathrm{I}$ from ro a.m.). Free, except on Mondays and Thursdays, when an admission fee of 25 cents is charged. Exhibition of a splendid collection of Animals, Birds and Reptiles. The fauna of Henry Hudson's time on Manhattan Island and Hudson River Valley will be indicated by the flag of the HudsonFulton Celebration. (Special illustrated catalogue describing same for sale.)

Take Subway trains marked "Bronx Park Express" to terminus at I8oth Street, or Third Avenue Elevated to Fordham Station. The entrances are reached by numerous surface cars.

REFORMED DUTCH CHURCH. The Reformed Protestant Dutch Church of the City of New York will make an exhibit in the chapel of the Church of St. Nicholas, Fifth Avenue and 48th Street, during the week of the celebration, 9 to 5 daily.

This Church was organized A.D. I628, and the exhibit will comprise articles connected with its long history.

VAN CORTLANDT HOUSE MUSEUM, in Van Cortlandt Park. This fine colonial mansion, built in I748, with furniture of the period, is one of the old houses within the area of Greater New York; it is in the custody of the Colonial Dames of the State of New York. Open daily, 9.00 a.m. to 5.00 p.m. Special Exhibition of Mezzotint Portraits of men prominent in political life prior to the Revolution; Wedgwood's Medallion Portraits of Illustrious Personages; Cartoons and Caricatures of political events, etc. (Special illustrated catalogue on sale.)

Take New York Central Railroad from Grand Central Station; Sixth

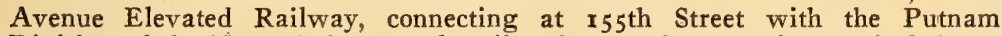
Division of the New York Central Railroad; or Subway trains marked "Van Cortlandt Park."

WASHINGTON'S HEADQUARTERS (The Jumel Mansion). Roger Morris Park, Edgecombe Avenue and one Hundred and Sixty-second Street. Built about 1760 . Under the Department of Parks. Exhibition by the ladies of the Washington Headquarters Association, Daughters of the American Revolution. Open free daily, including Sundays, from 9 a.m. to 5 p.m. Special features: Collection of Colonial furnishings, objects and pictures; also the Bolton Collection of War Relics of the Revolution.

Take Amsterdam Avenue surface cars; Sixth Avenue Elevated Railway to One Hundred and Fifty-fifth Street, or Broadway Subway to One Hundred and Fifty-seventh Street. 




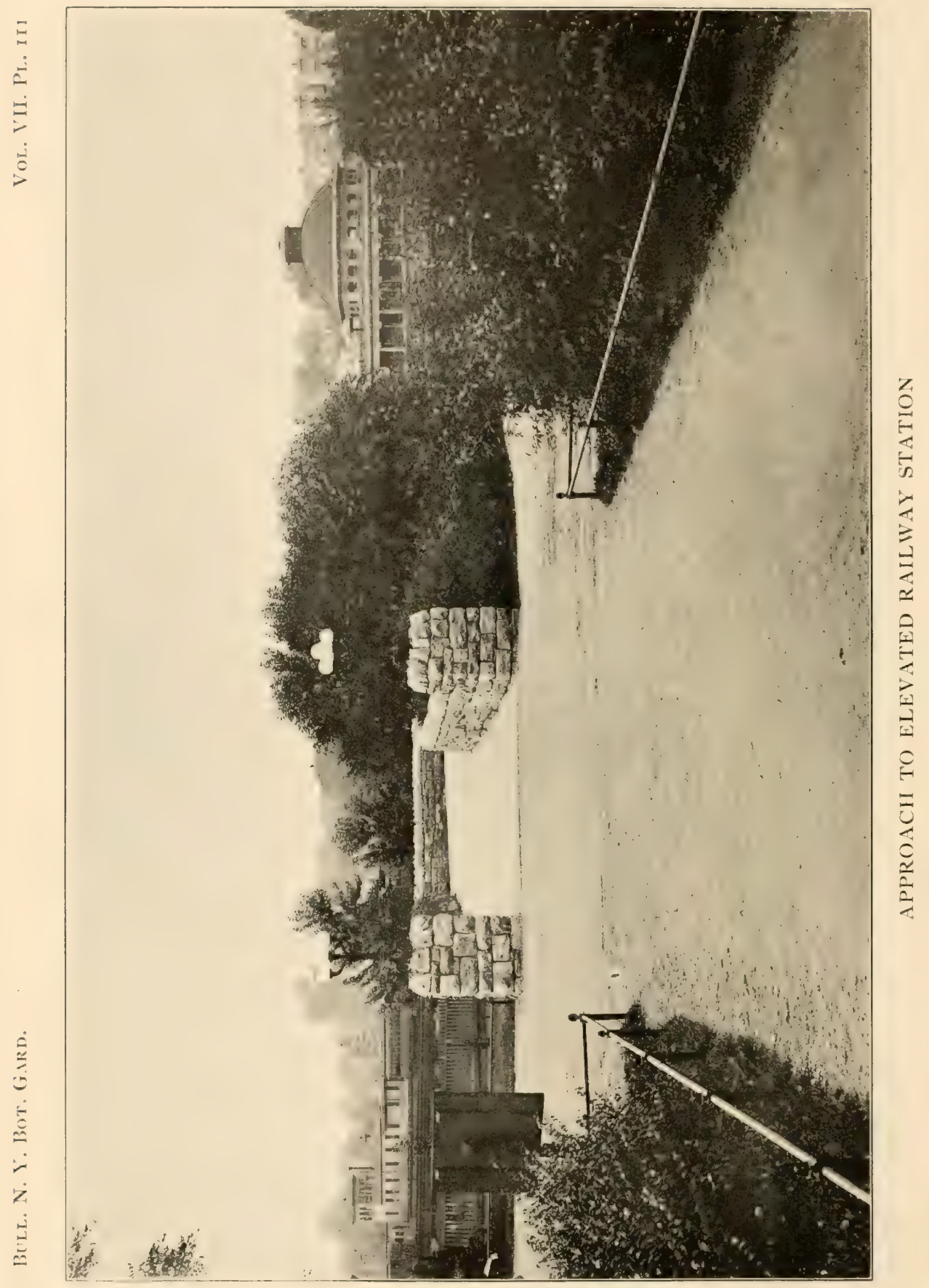




\section{DESCRIPTIVE GUIDE TO THE GROUNDS, BUILDINGS AND COLLECTIONS}

\section{Location}

The New York Botanical Garden is situated in the northern end of Bronx Park, the reservation including about $25^{\circ}$ acres of land of a very diversified character, furnishing natural landscapes of great beauty and variety.

\section{Means of Access}

The Garden is conveniently reached in the following ways:

I. By the Harlem Division of the New York Central and Hudson River Railroad to Bronx Park Station.

2. By the Third Avenue Elevated Railway system to the terminal station of that road at Bronx Park.

3. By the Subway, Lenox Avenue and West Farms branch with transfer at I49th Street and Third Avenue to Elevated Railway, thence to Bronx Park Station.

4. By trolley car on Webster Avenue to 20oth Street or the Woodlawn Road. This line connects with lines from the western part of the Bronx on Kingsbridge Road, and on Tremont Avenue, and also with the line to Yonkers.

5. By trolley line on the White Plains road east of Bronx Park from West Farms, Williamsbridge, and Mt. Vernon, connecting with lines from the eastern part of the Bronx at West Farms and at Mt. Vernon.

6. By driveways in Mosholu Parkway from Van Cort- 
landt Park; from Pelham Bay Park through Pelham Parkway; through the Crotona Parkway and Southern Boulevard from Crotona Park; there are also driveway entrances at 2ooth Street, convenient for carriages coming from Jerome Avenue; at Newell Avenue, at the northern end of the Garden, for carriages coming from the north; at Bleecker Street on the eastern side of the Garden for carriages coming from the east; and at the Woodlawn Road, convenient for carriages coming from Yonkers, and from other points west and northwest of the Garden.

\section{Purposes}

The New York Botanical Garden was established by an Act of the Legislature of the State of New York passed in I 89 I and amended in I 894 "for the purpose of establishing and maintaining a Botanical Garden and Museum and Arboretum therein, for the collection and culture of plants, flowers, shrubs and trees, the advancement of botanical science and knowledge, and the prosecution of original researches therein and in kindred subjects, for affording instruction in the same, for the prosecution and exhibition of ornamental and decorative horticulture and gardening, and for the entertainment, recreation and instruction of the people."

\section{General Plan}

The general plan of development includes:

I. The largest conservatories in America, for tine cultivation of plants of tropical regions, one located near the entrance at the elevated railway station, and a second very large range, partly constructed, near the Bleecker Street entrance on the eastern side of the Garden.

2. The largest botanical museum in the world, located near the Bronx Park station of the New York Central Railroad and the Mosholu Parkway entrance. This building includes a large lecture hall for public lectures in the basement; and the library, laboratories for instruction and research, and the herbarium, on the upper floor. 



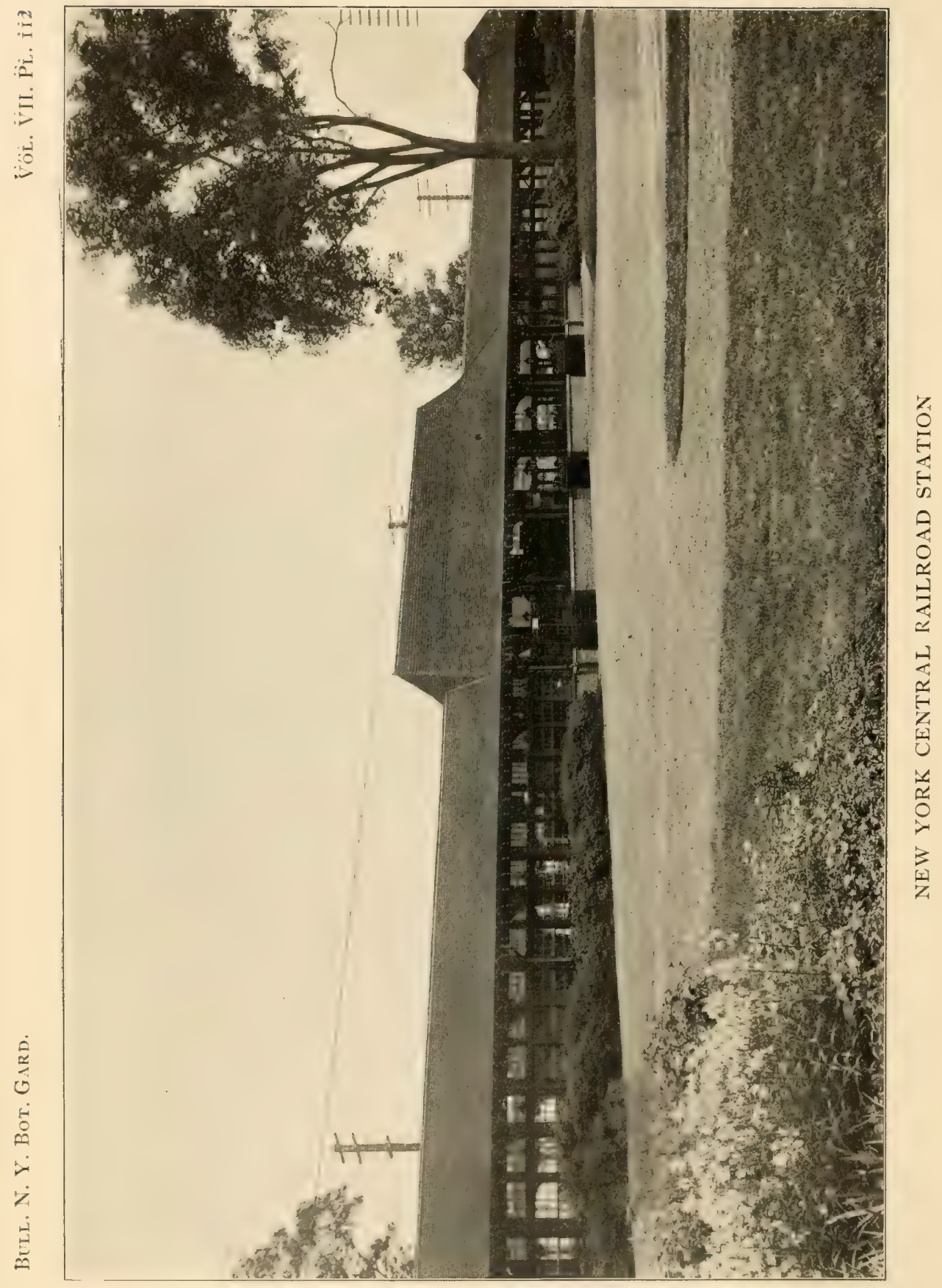


3. The pinetum, or collection of cone-bearing trees, mostly evergreens, which is being brought together on the hills and slopes on all sides of the conservatories, range $\mathrm{I}$, and in the space between that structure and the museum building.

4. The herbaceous grounds, situated in a valley east of the conservatories, range I, near the Southern Boulevard entrance, containing collections of hardy herbaceous plants, arranged by botanical relationship, and also a collection of similar plants, arranged to demonstrate elementary botany; the economic garden, a plantation designed to illustrate hardy plants whose products are directly useful to man, is being installed in the northern part of the same valley.

5. The fruticetum, or collection of hardy shrubs, located on the plain northeast of the museum building at the Woodlawn Road entrance and extending northward into the north meadows; this collection is also arranged by botanical relationship.

6. The deciduous arboretum, or collection of trees which lose their leaves in the autumn, located along the entire eastern side of the grounds from south to north.

In addition to these artificial features, the following natural features are of special interest:

7. The hemlock grove, a forest of the Canadian hemlock spruce, clothing the hills between the museum building and the Bronx River and covering about forty acres, considerable portions of it being primeval.

8. The gorge of the Bronx River, extending south from the waterfall at the Lorillard Mansion, along the edge of the hemlock grove to the southern boundary of the Garden.

9. The north meadows and river woods along the Bronx River from the northern end of the hemlock grove to the northern end of the Garden.

\section{The Conservatories}

\section{Range No. I.}

This great glass-house, located but a short distance from the terminus of the Third Avenue Elevated Railroad, is $5^{\mathrm{I} 2}$ 
feet in length, with a central dome about 90 feet in height, and wings extending from the main range in such a way as to form a court open to the southwest. The area under glass is about one acre. The building stands on a terrace 5 feet in height, approached by six flights of cut granite steps connecting with the path and driveway approaches. The house contains fifteen compartments, separated by glass partitions and doors.

House No. I contains palms of numerous species from all parts of tropical and warm regions, both of the Old World and the New. Of West Indian palms, the collection contains the royal palm of Cuba and Florida, an elegant plant of the corozo palm (Acrocomia media) of Porto Rico and the Windward Islands; the cocoanut palm, planted in all tropical countries for its fruit and for the numerous uses to which its fiber, wood and leaves are applied; it is not definitely known that the cocoanut palm is a native of the West Indies, and where in the tropical regions it actually originated is uncertain. Central and South American palms are illustrated by the delicate Cocos Weddelliana from Brazil, by the silvertop palm (Coccothrinax argentea), and by the curious Mexican Acanthorhiza aculeata, with spine-like roots on its trunk. Old World species are shown in a very large tree of the Chinese fan-palm, by the date palm (Phoenix dactylifera) of northern Africa, by the very broad-leaved Phoenicophorium sechellarum, native of the Seychelles Islands, and by numerous other large species from the Pacific islands. Related to the palms and shown by numerous specimens in this house, we find a number of species of the cyclanthus family, the most conspicuous being the Panama hat plant (Carludovica palmata), from the young leaves of which the costly Panama hats are made. Opposite the entrance to the court in this house, is a group of bamboos, which belong to the grass family, the most noteworthy of them being the Chinese bamboo (Bambusa vulgaris), whose stems reach into the upper part of the dome; this plant grows with great rapidity each year by new shoots which come up from under ground, 



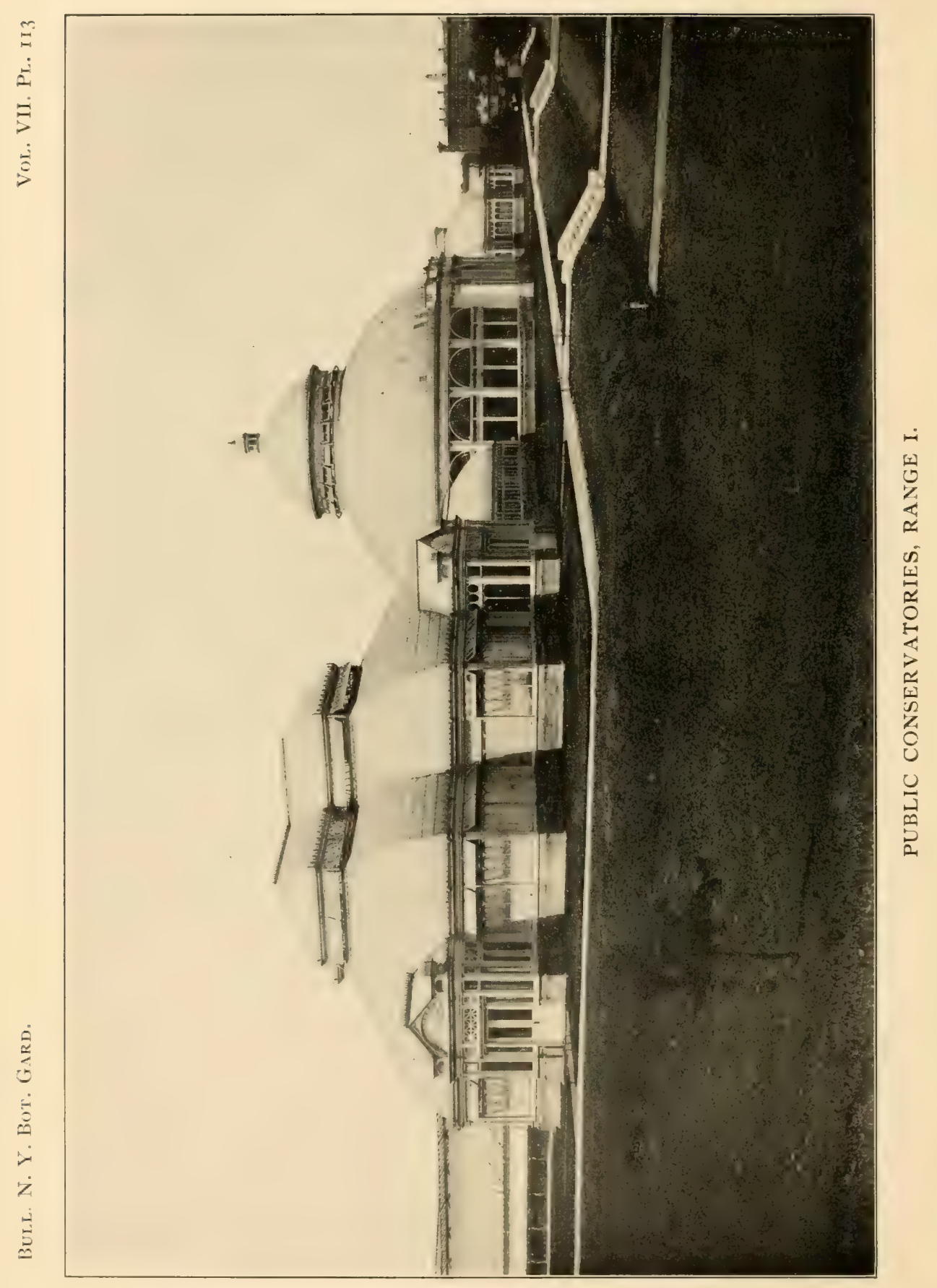


our measurements showing that they reached 65 feet in height in 95 days, a rate of about 8 inches a day. The plant has been introduced into the West Indies, and in places where it grows its stems are put to a great variety of uses in construction, for water pipes and for various utensils.

House No. 2 also contains specimens of the palm family, the smaller specimens of tropical species being exhibited here.

House No. 3 contains specimens illustrating several families of monocotyledonous plants of tropical regions. The amaryllis family is represented by a number of species of the spider lily (Hymenocallis), bearing large white flowers, the commonest being Hymenocallis caribaea from the sandy coasts of southern Florida and the West Indies; large plants of the genus Crinum, some of which have white flowers and some red or purple, may be seen on the middle bench, and the maguey of the West Indies (a spiny-leaved relative of the century plant, native of the West Indies, and used there for hedges), on the northern bench; this name maguey is also applied in parts of the West Indies to species of $A$ gave, which will be found in house No. 6 .

Numerous representatives of the lily family, especially of the genus Dracaena, may be found on the south bench, and these are much used for ornamental planting in the tropics; here also are plants of the genus Sansevieria, the bow-string hemps of Africa; a valuable tough fiber is derived from their leaves; larger plants of the lily family may be found in the adjoining house No. 4, a portion of this house being given over to tall dracaenas and their relatives.

The arrow-root family is illustrated by the arrow-root (Maranta arundinacea), native of South America, but widely cultivated in the West Indies, its roots furnishing the commercial product; Calathea comprises a large number of tropical American plants noteworthy for their fine foliage, and there are other genera represented.

House No. 4. Here are brought together many kinds of large tropical plants belonging to families also represented in the smaller houses, but too tall to be grown on the benches. 
The interesting screw-pines, natives of the Old World tropics, are illustrated by several species, the leaves of which are used in the manufacture of mats, hats and baskets. These plants are not at all related to pine trees, the latter part of the name referring to the slight resemblance the leaves bear to those of pineapple plants, which are commonly called pines in the tropics, while the remainder of the name was suggested by the spiral arrangement of the leaves.

In this house may be found large specimens of the aroid family, the most noteworthy one of these being a magnificent plant of Veitch's tail-flower (Anthurium Veitchii), from Colombia, which is believed to be the most elegant plant of its kind in cultivation; climbing on trunks of trees set as supports, will be found a number of vines of the genera Philodendron and Monstera, the latter a native of Mexico, producing an edible fruit with the odor of pineapple.

A large tree of the common rubber plant, much grown in parlors, may be found in the center of this house, reaching to the roof; this is a native of tropical Asia and yields some rubber, but not in as great quantity nor of as good quality as the other rubber trees of South and Central America; it is a species of fig (Ficus elastica); other species of Ficus are shown in this house, notably a fine tree of Roxburgh's fig, which bears its inedible fruit in bunches near the base of the tree, and a specimen of the Banyan tree (Ficus benghalensis). Chocolate trees (Theobroma Cacao), native of tropical America, may be found near the western door of this house; the small white flowers are produced on the trunk and on branches, and a few of them develop into the large woody pods containing the seeds or chocolate beans, which are dried and ground up into chocolate and cocoa; specimens illustrating the chocolate industry will be found in the economic museum. The papaya, or papaw, also of tropical America, is illustrated by a tall tree in the middle of this house; its fruit, esteemed as an aid to digestion, is borne just under the crown of leaves. A specimen of the bread-fruit tree (Artocarpus incisa) may also be seen here; originally from the 
islands of the Pacific, it was introduced into the West Indies in the latter part of the eighteenth century.

Several interesting tall vines climb on the pillars of this house, among them the night-blooming jessamine (Cestrum Parqui) of tropical America, which opens its flowers after dark and exhales a delicious perfume, the flowers remaining open during part of the morning; Henderson's Allamanda, of Brazil, with its showy large yellow flowers, climbs to the roof.

House No. 5. The plants in this house are from desert regions. Especial attention is called to their fleshy stems or leaves which serve as storage organs for a water supply to carry them over periods of drought. On the right hand bench, as one enters from No. 4, are mainly plants from southern Africa: the carrion flowers (Stapelia), relatives of our common milkweed of the roadsides; Aloe, Gasteria, Haworthia, and other South African representatives of the lily family.

The central bench is entirely devoted to the cactus family, which, with few exceptions, is American. Nearly all these plants are devoid of leaves, these organs, when present, being mostly small and inconspicuous; in the genus $O$ puntia they are usually present on the young growths as awl-shaped bodies, while in some few species they are much larger and remain for some time; in the genus Pereskia, specimens of which will be found in house No. 7 , the leaves are large and well developed. The stems of the cacti are fleshy and assume a great number of forms; in Opuntia the stem is composed of joints, either cylindric or broad and flattened. In Cereus the stems are angled; in Carnegiea they are thick massive columns with many longitudinal ribs; in Echinocactus the plant-bodies are but little elongated, or almost globular, while in other genera the plant-body is covered with rows of spirally arranged projections. The flowers of many cacti are exquisite in form and color; they are borne on various parts of the plant-body, in the turk's-head cactus on a curiously modified portion of the top. A plant of economic interest here is 
Nopalea coccinellifera upon which the cochineal insect breeds; it is from these insects that the dye cochineal is obtained.

On the remaining side bench is the stone-crop family, represented by many interesting and beautiful forms. The echeverias from Mexico and Central America, and the sempervivums, or house-leeks, from the Old World, are conspicuous among these. Many of the stone-crops are hardy plants and a collection of these may be found at the herbaceous grounds. Only a few cactuses are hardy. A large number of the specimens belonging in this house and the next may be found during the summer in beds in the conservatory court.

House No. 6. This is also a desert house. On the two corner benches to the right, as one enters from No. 5 , is a collection of century plants (Agave), a large genus known only from the New World; other and larger plants of this same genus may be found in the central portion of the house. Conspicuous among these are: the thread-bearing agave, Queen Victoria's agave, the sisal plant (Agave sisalana); and the common century plant (Agave americana). The first two are decorative and curious; from Agave sisalana is manufactured the sisal hemp of commerce; the last, Agave americana, is well known, and it is from the sap of related species that the Mexican drink "pulque" is obtained by fermentation. It is popularly believed that the century plants flower but once in a hundred years, and then die; it is true that the plant dies when done blooming, but it blooms at a much earlier age than a century, sometimes when but eight or ten years old, it is said. A curious desert plant among the century plants on the side bench is called by the natives of Mexico, its native country, "huariqui" (Ibervillea sonorae); during the rainy season green stems arise from these large woody plant-bodies, which at other times remain in a resting condition.

A group of the lily family may be found in the central portion of this house. This comprises members of the genera Aloe, Yucca and Dasylirion. A group of cacti may also be 
seen here, the most imposing figure of which is the giant cereus, Carnegiea gigantea, known as "sahuaro" by the Mexicans and Indians of its native country, Arizona and Sonora. The plants here shown were obtained by an expedition sent to those regions by the Garden in 1902 , and they represent perhaps the largest specimens in cultivation in the east. Several large specimens of the hedgehog cactus, secured at the same time, form part of this group. The Indians in the desert often secure a supply of drinking water from these plants by cutting off the top and macerating the interior substance. A number of other large and rare cacti secured by a Garden expedition of 1906 have recently been added to this collection. On the remaining corner benches may be found the fig marigolds, from southern Africa, desert members of the pineapple family, and representatives of the spurge family.

House No. 7. Many families are shown here, the representatives of which are tropical. The members of the mimosa and senna families, largely represented in this house, are curious in their sleep movements; as daylight wanes the leaves begin to droop and the leaflets to fold up. Belonging to the senna family may be mentioned: the logwood tree (Haematoxylon campechianum), widely distributed throughout tropical America; the copaiba tree (Copaiva officinalis), one of the trees from which copaiba is obtained; and the tamarind tree (Tamarindus indica), valuable for its fruit. In the mimosa family the humble or sensitive plant (Mimosa pudica), whose leaves fold at the least touch, is of peculiar interest. The mahogany tree (Swietenia Mahagoni), and the cocaine plant (Erythroxylon Coca), from South America, are important economic plants. In the custard-apple family are the cherimoyer (Anona Cherimolia), and the sour sop (Anona muricata). The mammee-apple is another tropical fruit, belonging to the gamboge family. The spurge family is represented in several curious forms, many of them much resembling members of the cactus family; while others bear large leaves, as is the case in the chenille plant, or Philippine 
medusa (Acalypha hispida); belonging to this family also is the plant bearing physic or Barbados nuts (Jatropha Curcas). The showy genus Codiaeum, commonly known as crotons, also belongs to the spurge family. Members of the cactus family, represented by several genera, especially of kinds growing naturally on trees in tropical forests, will be found near the spurge family. Decorative members of the ginseng family are also in this house.

House No. 8. As in house No. 7 , the plants assembled here are of miscellaneous interest. The madder family is present in showy forms of ixoras, hoffmannias and rondeletias. There are striking forms of the potato family; also attractive representatives of the gesnerias, in the African or Usambara violet, and several forms of the genus Trichosporum, excellent basket plants. On the north side bench may be found a collection of begonias in many forms, ranging from the large-leaved Begonia nelumbifolia, of the West Indies, to the small-leaved $B$. foliosa, from Colombia, and the dainty little $B$. rotundifolia, known only from the island of Haiti, and for many years lost to science. The showy foliage forms of Begonia Rex are present in great variety. Among the more noteworthy economic plants are the ramie plant (Boehmeria nivea), a native of China, from the fiber of which the so-called grass-cloth is woven.

House No.9. This is the aquatic house, and plants which find their homes in the water or require much moisture are brought together here. From the bridge spanning the pool the various features may be readily observed. Fringing the pool on the right, as one enters from house No. Io, are members of the sedge and grass families, while on the left hand side the fringe is made up entirely of grasses, largely of the graceful bamboos. Of special interest among the sedges is the Egyptian paper-plant (Cyperus Papyrus), from which many of the ancients obtained their writing paper. Among the grasses by far the most important is the sugar cane (Saccharum officinarum); from the lower portions of its stalks the juice is extracted by pressure, and from this juice 
sugar is manufactured. Among the plants in the pool are many with attractive flowers; conspicuous among these being water-lilies (Castalia), of which there are several different kinds; the water hyacinth; the parrot's-feather, with its delicate feathery masses of green; the water poppy; the water snowflake; the water lettuce, a member of the aroid family; the floating fern; and some odd little plants related to the ferns, members of the genus Salvinia.

House No. IO contains specimens of the aroids, represented by a large number of different species. The plants of this family (Araceae) are mostly of tropical distribution, but they are represented in our northern flora by the skunk cabbage, the jack-in-the-pulpit, and the sweet flag; the most familiar one in cultivation is the calla lily (Zantedeschia aethiopica), not botanically a lily. The plants all have spikes of very small flowers closely massed together, and usually subtended by a broad leaf-like structure which is known as the spathe; this is usually highly colored, pure white, yellow, red or scarlet, and is commonly thought of as the flower, though not botanically so; species of Anthurium, known as tailflowers, are abundant in the West Indies and tropical America, as is the genus Philodendron, signifying tree-loving, on account of many species being vines climbing high on the trees in tropical forests; numerous species have underground stems and branches which contain much starch and are cultivated in the tropics for food, under the name of yautias and taras. Plants of the same family, too large for exhibition in this house, may be found in house No. 4. This house is ocrupied also by plants of the pineapple family. These are nostly plants which live on the trunks and branches of trees in tropical forests, and are therefore called epiphytes, signifying plants growing upon other plants; many of them are exceedingly beautiful in foliage and in flower; the so-called Florida moss, or Spanish moss, clothes the trees of the liveoaks in the southern Atlantic States, and is not a moss at all, but a plant bearing small flowers which show its relationship to others of this family. The pineapple itself, doubtless the 
most familiar member of this group, has been cultivated in tropical regions for an indefinite period for fruit, and is not certainly known in the wild state; the pineapple fruit is the ripened bunch of flowers which forms at the top of the stem; the plant is propagated by cutting off the tuft of leaves, which is found on the top of the fruit, and by suckers which sprout from the side of the plant near the ground; it is an exception to the tree-loving habit of most of the family, in growing on the ground, and is cultivated in the Bahamas and on the Florida Keys, often in very rocky soil. One of the very spiny-leaved species, Bromelia Pinguin, is widely utilized as a hedge plant in the West Indies. Hanging from the rafters on both sides of this house may be found baskets containing the East Indian pitcher-plants, Nepenthes; these are mostly vines, growing naturally on trees, their leaves curiously modified at the ends into hollow structures provided with lids and technically known as pitchers, which are often wrongly regarded as the flowers; these pitchers contain water and secrete from their sides a glutinous liquid which digests insects that fall or crawl into the pitchers; this form of nutriment is apparently not necessary at all, however, to the growth of the plants; the flowers are small but borne in large clusters arising from the stems and may often be seen in this collection.

House No. II. Here are brought together many kinds of tropical plants belonging to the banana, ginger and canna families. There are also here a few plants of the pineapple family too tall to be shown on the benches in house No. Io. The collection of bananas and their relatives occupies the greater part of the space and one or more of the specimens is usually in fruit; the collection contains both the edible, commercial bananas and the plantains, and also several species whose fruit is not edible, but whose interest lies in their decorative leaves and flowers. The stems and leaves of all these plants contain some fiber, which is produced in enormous quantities in the Philippine Islands from Musa textilis, and is the well-known Manila hemp. The supply of fruit for the United States comes mostly from Central America 
and the West Indies, and some from northern South America. Bananas will grow in southern Florida, but the rocky soil of that region is not well adapted to their cultivation. The traveler's tree, from Madagascar, is shown in several fine specimens, and gets its English name from the fact that the axis of each long leaf-stalk contains a grat deal of water which can be tapped and drunk. The bird-of-paradise plants, which take their name from their gaudy flowers, will be found in this group; they are natives of southern Africa and belong to the genus Strelitzia. Another genus of the banana family, Heliconia, is also represented by several species, called wild plantains, natives of tropical America.

Here also may be found several species of the genus Costus and of other genera of the ginger family, including the ginger plant (Zingiber Zingiber).

House No. 12. The plants in this house, as well as those in house No. I4, are mostly natives of warm-temperate regions, and are arranged in botanical sequence, with a view to furnishing a collection for the comparative study of plant families and genera; to make this as complete as possible, as many representatives of families and genera are brought together as space and cultural conditions permit. Cultural requirements necessitate placing the ferns and their allies somewhat out of their sequence position, at the south end of the west side bench. The east side bench is devoted to the pine family, the yew family, and to the endogenous plants, the last named terminating with the orchids, next the banana house. The sequence of exogenous plants begins on the west side, bench, as one enters from house No. I3, crosses to the central bench at the ferns, and continues around that, ending in this house with the loasa family, near the fern house. The sequence is then continued in house No. I4, beginning with the mezereon family on the north side bench, at the entrance from house No. 13, continuing around the central bench and ending with the thistle family on the end of the south side bench near the entrance to house No. I3.

Among the more interesting species on the west side 
bench are many Australian plants, represented by grevilleas, hakeas, and others; a group of insectivorous plants may also be found here; among these are the pitcher plants (Sarracenia) in several species; the pitchers contain a liquid in which the insects are drowned, the fluid resulting from their decay being absorbed by the pitchers; these structures form a part of the leaves and are a modification of the petiole. The sundews (Drosera) secrete a sticky substance from the gland-hairs on their leaves, which can digest insects and other animal matter. On the central bench may be found a group of the rue family; to this belong, among others, the oranges and lemons, of which a number of small specimens are here, others being placed in house No. 13. A peculiar plant of this family is Agathosma apiculata, of southern Africa; its leaves are full of glands which secrete an oil exhaling a disagreeable odor quite apparent at times. On the east side bench are members of the lily family and the amaryllis family, with many other endogenous plants, including a collection of orchids which grow in warm temperate regions or in the mountainous sections of the tropics. In the yew family, perhaps the most interesting are two small plants of the "stinking cedar" (Tumion taxifolium) so-called by the natives where it grows; it is known to occur in a wild state in a small area along the Apalachicola River in Florida.

House No. I3. This house contains such plants of warmtemperate regions as are too large for proper exhibition in houses $I_{2}$ and 14 . The endogenous plants may be found on the side next house No. I4; the remainder of the house is occupied by exogenous plants. Opposite the entrance from house No. I4 is a group illustrating the pine family and the yew family. The most conspicuous objects among the former are the araucarias, which take the place in the southern hemisphere of the pines in the north; Araucaria brasiliana and $A$. Bidwillii are prominent among these; the common Norfolk Island pine (Araucaria excelsa) is shown in several large specimens. To the right of this, across the path, will be 
found specimens of the New Zealand flax (Phormium tenax), and on one of the trellises in the rear is a vigorous plant of the Cherokee rose. To the left, a little beyond the pine family, is the myrtle family; prominent in this is a group of the gum-trees of Australia and Tasmania (Eucalyptus); these trees occur in large forests, and sometimes attain a height of 200 to 400 feet. A large specimen, some ten or twelve feet tall, of the bottle-brush tree (Callistemon citrinus) will be found here; the red flowers are borne in long cylindric clusters, much resembling a common bottle-brush, whence the popular name. Farther to the left is a large plant of Hydrangea hortensis; this presents a gorgeous show of blue flowers early in the summer. In the corner to the right is a specimen of the camphor tree (Cinnamomum Camphora), from which the camphor of commerce is derived. Opposite the camphor tree is a group containing the common garden camelia, and the important commercial plant, Thea sinensis, from which is obtained our beverage tea; black and green teas are obtained from the same plant, the difference in color being due to the method of preparation; the tea plant is extensively cultivated in many warm and tropical countries, tea as a beverage having been used by the Chinese from time immemorial; its first introduction into Europe is said to have been by the Dutch in I6 Io. Further along to the left, beyond the group of Australian acacias, of which there are many specimens, are several plants of the fig tree (Ficus Carica), from $w^{k} 1 \mathrm{ch}$ the edible figs are secured; the leaves drop off in winier, and so for a short time the plants are placed elsewhere. A little beyond these to the left may be found a group of oleanders; a poisonous principle occurs in the flowers and leaves of these plants, and especially in the bark. A plant of great economic importance in the olive family is the olive tree (Olea europaea), of which a small specimen may be found near the oleanders; this plant was originally from the Mediterranean region and the Orient, but has now been largely introduced into cultivation in other warm countries; in the middle of the eighteenth century it was first introduced into 
California, at San Diego, it is said, and is now largely cultivated in southern California. On one of the columns near the olive is a fine plant of Bougainvillaea, a native of Brazil; the bracts which surround the small flowers are bright magenta colored; when in full bloom the plant makes a gorgeous show. On one of the trellises back of the group of the amaryllis family is a plant of the yellow jessamine (Gelsemium sempervirens) of the south; it sends out its pretty flowers usually in February, and they persist for several weeks. In this house may also be found a number of palms. Among these may be mentioned the characteristic fan-palm of the California desert (Neowashingtonia robusta), and the palmetto (Sabal Palmetto), of our southern States. A few temperate tree-ferns are also placed here.

House No. I4. The general arrangement of this house was mentioned when describing house No. I2. Entering from house No. 15 , to the left may be found plants of the rosemary; this enjoys a reputation of long standing, for it was held in high esteem by the ancient Greeks and Romans, being regarded by them as the emblem of fidelity. A little further to the left is the parachute flower (Ceropegia Sandersoni), from Natal. On the right are many interesting members of the thistle family. On the other side of the house may be found Aucuba japonica, from Japan, and Corokia Cotoneaster, from New Zealand, both members of the dogwood family, but not much resembling our common flowering dogwood. Other plants of interest may also be found here.

House No. I5. The orchid family, to which this house is devoted, is a widely distributed one, occurring in all tropical regions, but finding its greatest development in the Old World in India and the Malayan region, while in the New World its greatest numbers occur in Brazil and other parts of northern South America. In temperate regions relatively few species are found, while in very cold countries they are entirely absent. Most of the tropical forms are epiphytes, that is, they grow upon trees and usually have bulb-like or thickened stems and fleshy leaves for the conservation of 


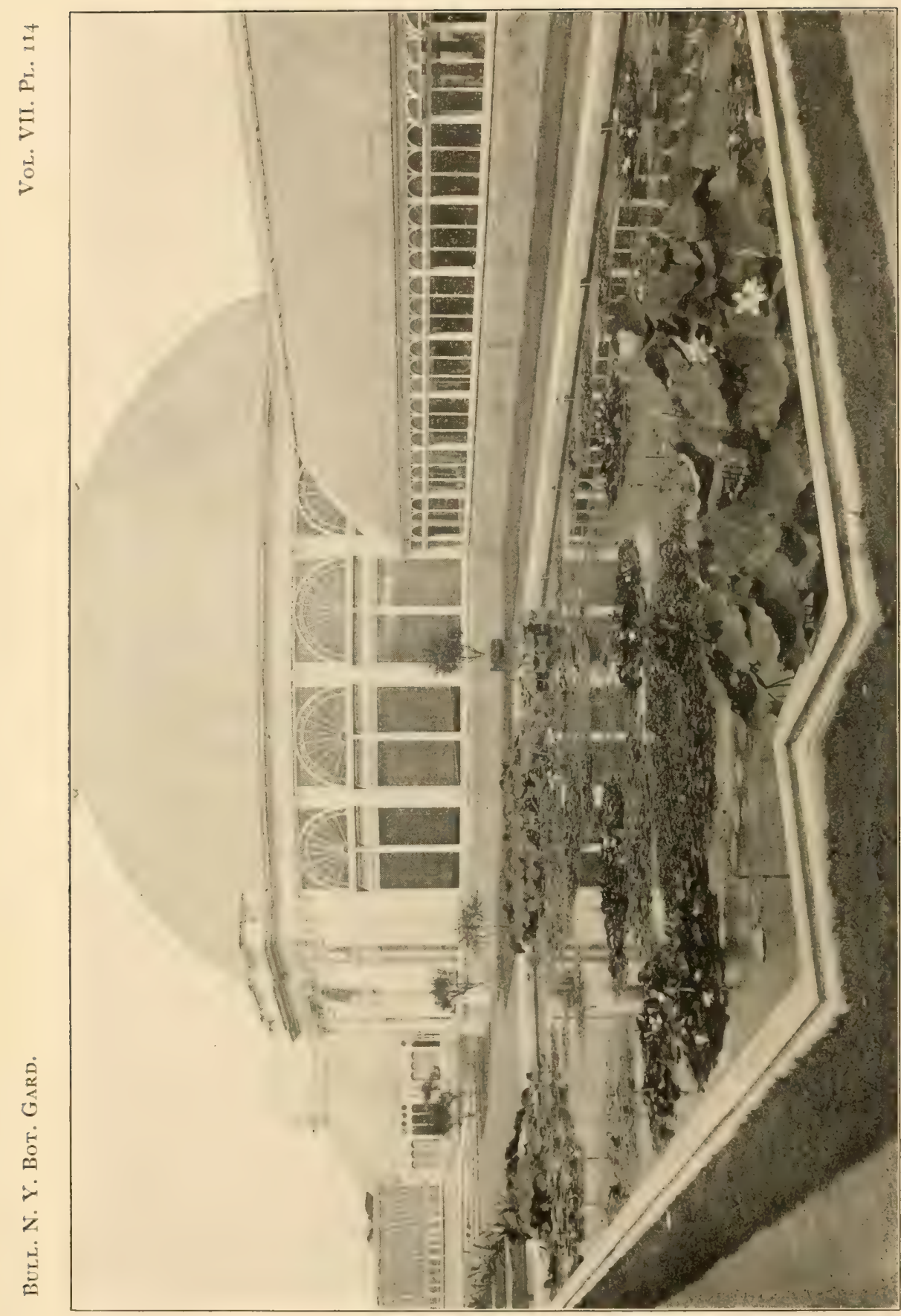

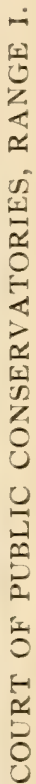


their water supply, as, from their habitat, this supply must be precarious. In temperate regions nearly all of the species are terrestrial, and have thin leaves, the soil about their roots serving to protect them from the cold and also giving them a more constant water supply: they do not, therefore, need pseudobulbs or thickened stems. Coming from all parts of the world as they do, their blooming time varies greatly, so that at almost any time of the year, be it winter or summer, some of these interesting plants may be found in bloom.

On the central bench is an interesting palm, the double cocoanut (Lodoicea maldivica), a native of the Seychelles Islands, also known as the coco de mer, and coco des Maldives, and one of the rarest palms in cultivation; in the specimen here shown the upper portion of the seed may be seen projecting above the soil. The tree in its native wilds attains a height of ninety feet, bearing aloft a magnificent crown of green leaves which make it an important feature of the landscape. This is the only plant in this house not a member of the orchid family; it is kept here for cultural reasons.

Conservatory Court. There are two attractive features here during the open season, viz., the water lily collection and the collection of desert plants. The water lilies may be found in two tanks, one in each end of the court. In the easterly tank are placed the hardy sorts, such as are able to withstand the severe cold of our winters, which remain permanently where they are, winter and summer. In the westerly pool are the tender kinds, or such as require protection during the winter, and many of these are stored in a warm cellar during winter and placed on view again in the spring. The most conspicuous of the tender sorts are the royal water-lilies from South America; these are not hardy in this climate, and, as they are too large to protect from the cold, they are grown anew from seed each year; the seeds are sown in the propagating houses late in winter, and the young plants placed on view late in the spring or in early summer. 
In summer the collection of desert plants is in three beds in front of the entrance to house No. I. The central bed contains American desert plants only, made up largely of members of the cactus, amaryllis and lily families; in the easterly beds will be found desert plants from southern Africa. In the western bed are representatives of the orpine family.

Conservatory Flower Beds. To the north of the conservatories, occupying a portion of the area below the terrace, are several large plots devoted to a miscellaneous display of shrubs, evergreens and herbaceous plants. Attractive flowers may be seen here from the earliest spring until late autumn, while the evergreens make a pleasing effect during the winter. The herbaceous plants are plainly labeled, thus adding much to their interest for the visiting public.

\section{Range No. 2}

This range, four houses of which have been constructed, is located on the easterly side of the grounds, in the midst of the deciduous arboretum. The completed portion consists of a transverse range, running east and west, divided into three compartments, and a smaller house at right angles to this range. The tropical ferns and their allies and the cycads are exhibited here.

In the easterly compartment of this transverse range the collection of sago palms or cycads has been installed. This, family of plants is represented by large specimens of Cycas revoluta, from Japan; by Cycas circinalis, from the Molucca Islands; by a single plant of the rare Stangeria eriopus, from southern Africa, where it is known as the kaffir's-head; by a number of specimens of the genus Zamia, including the small Florida coonties; and by the Kaffir-bread (Encephalartos), two species, from Africa; the stems and trunks of plants of this family contain much starch, which is extracted, in the countries in which they grow, by crushing and washing, and pass into commerce under the name of sago starch.

In the middle and westerly houses of the transverse range 
may be found the tropical tree-ferns and the larger specimens of the low ferns and fern-allies.

The graceful tree-ferns usually inhabit the mountains of the tropics, commonly at an elevation of I 500 feet or more. Many of the plants here have been secured by Garden expeditions to different parts of the American tropics. Another feature of interest is the collection of staghorn-ferns, hanging over the walk in the center house; the application of the common name staghorn is quite evident in several of the species. Suspended from the roof in baskets are many desirable ferns. A fern from China and Tartary, known as the Scythian Lamb (Cibotium Barometz), may be found here; it is of interest as forming the basis of a marvellous tale, current in early times, to the effect that on a vast plain to the eastward of the Volga occurred a wonderful plant, looking like a lamb; this animal, so the story ran, was supported upon a stalk and as soon as it had exhausted the vegetation at hand died from starvation.

In the small house may be found a collection of tropical ferns arranged in botanical sequence, thus bringing closely related families and genera into juxtaposition and enabling a comparative study of these plants to be made. It is only possible to represent in this sequence the position of the treeferns by very small specimens. These may be studied to better advantage in the larger houses.

Power Houses. Steam for heating the conservatories, range $I$, is supplied from the power house, located near the New York Central Railroad just south of the 2ooth Street entrance and connected with the conservatories by a subway about six hundred feet long containing the steam mains; five boilers are installed and supply steam not only to the conservatories, but also to the museum building through another subway about twelve hundred feet in length.

Steam for heating the conservatories, range 2, is supplied from a boiler house near this structure, a little to the north. 


\section{The Botanical Museum}

The Museum Building has a frontage of 3 I 2 feet, and in so far as now constructed, a depth of about 90 feet; the plan of this building contemplates its future extension toward the rear, so as to form a quadrangle enclosing a court. The architectural style of the building is Italian Renaissance. The walls are of light-colored brick and the trimmings of terra-cotta. It has a steel frame and concrete floors. Three floors are devoted to public exhibits, while the upper floor contains study rooms, the library, laboratories and herbarium, which may be used and consulted by permission.

The building is approached by two straight driveways and accompanying sidewalks leading from the main park driveway near the New York Central Railroad station; this front approach to the building is ornamented by a bronze fountain executed by the sculptor Carl E. Tefft, and by terra-cotta fountains and marble seats designed by R. W. Gibson, the architect of the building. The vista lines are formed by four parallel rows of trees.

The public collections in this buildings are:

\section{THE MUSEUM OF ECONOMIC BOTANY}

This occupies the entire main floor, and here are brought together both crude and refined products of plants used in the arts, sciences and industries, illustrated also by photographs and drawings. The specimens are arranged as products, including food, drugs, fibers, gums, resins, sugars and others as indicated by the accompanying floor plan.

The arrangement of the larger groups is as follows: Foods and fibers occupy the west hall, the former in cases on the north side, the latter on the south. The west wing is mainly given over to exhibits other than foods, fibers, drugs and woods. The east hall contains the drugs, while the east wing is set aside for the woods and wood products, and for a collection illustrating North American dendrology.

Fibers. Cases I to I8.- In the first case of the series 



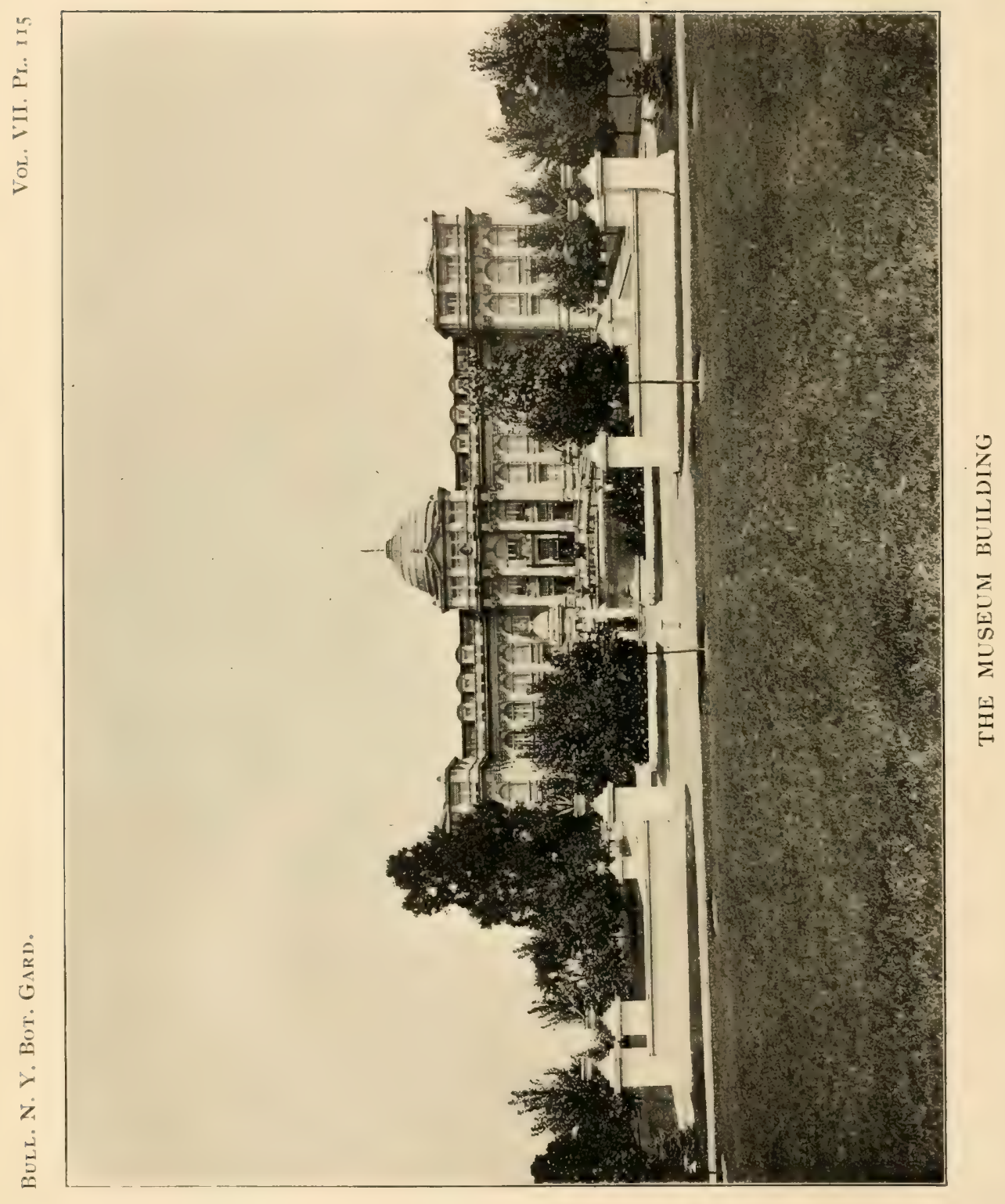


devoted to fibers may be found cotton, the most important of the vegetable fibers. It is derived from the fruit of the cotton plant (Gossypium), being the hairs that cover the surface of the seeds. The fruits of several different kinds of cotton may be seen with the cotton bursting from the capsule, while some of the many different products are also shown.

The fiber of many other plants, derived from the leaves, stem, bark, roots and other organs, is of great economic importance and is used, either in practically its natural condition, as may be seen by the specimens of fans, hats, boxes, bags, baskets, mats, matting, crude ropes, brooms, ornaments and toys, or it is manufactured into articles of commerce after processes which remove it considerably from its natural aspect or condition; for example, linen, which is made from the flax, plant; cloth, twine and rope, from jute, hemp and abutilon fiber; and paper made from wood and other fibers.

India Rubber and Allied Products. Cases 19 and 20.The first case in the west wing contains india rubber and allied products. Here are the implements and utensils used in collecting the rubber "milk" from the trees which grow in the tropical forests. Rubber is derived mostly from trees belonging to the mulberry family, spurge family and dogbane family.

Several varieties of rubber may be seen in the different stages of refinement, together with some articles as manufactured for the market. Here, too, is an allied product, gutta percha, which is derived from the trunks and foliage of certain trees belonging to the sapodilla family. These trees grow in many portions of the tropics.

Resins. Cases $2 \mathrm{I}$ and 22.-The cases devoted to resins contain on the one hand a large trunk of the long-leaf pine, with a turpentine box, together with a series of specimens of turpentine and resin, illustrative of the trade-classification of these products, and, on the other hand, a series of resins derived from other species of pine and related trees, and also those from trees representing the mulberry family, the mimosa family, the sumac family and the myrrh family. 
Spices and Flavoring Agents. Cases 23 to 26.-These substances form quite a large series in which is shown the parts of the plant that yield spices and flavoring extracts; for example, licorice is extracted from the roots of the licorice plant. Ginger is a rootstock, the underground stem of the ginger plant; cinnamon is a bark; bay, sage, mint, thyme are leaves; cloves are flowers; coriander, allspice, black pepper, celery seed, caraway seed, vanilla bean and tonka bean are fruits; mustard and nutmeg are seeds, and mace is the outer coat of the nutmeg.

Dye Stuffs. Case 27.-The dye stuffs are represented by logwood, madder, alkanet root, indigo and oak galls.

Tanning Materials. Cases 28 to 30.-The tanning materials are also very important from an economic standpoint; they are represented by saw-palmetto, mangrove, pine, hemlock and sumac. The crude materials of the mangrove and the saw-palmetto are accompanied by the fluid extract which contains the tannic acid and also by the spent material or refuse which remains after the extract has been made.

Fodder Plants. Cases $3 \mathrm{I}$ and 32.-Following the spices are fodder plants, which are shown as sheaves, and consist of grasses, sedges, bush-clovers and related plants.

Tobaccos and Masticatories. Cases 33 to 36.-Tobaccos are shown by a series of bundles of the cured leaves of the tobacco plant (Nicotiana) from different parts of America, and a series of articles as prepared for the market. Closely associated with tobacco are the masticatories or substances used for chewing. One of the most widely known forms is chewing gum, which is made by refining the crude chiclegum, which is the hardened milky juice of the sapodilla and related plants. In rural districts the exudation of resin found on the bark of conifers is used for chewing while still in the crude condition, but this substance is now refined and sold in our larger cities just as is the now more commonly used chicle-gum. An adjacent case is given over to:

Beverages, including Chocolate. Cases 37 to 4I. -Beverages are represented by both the non-alcoholic, as coffee, 

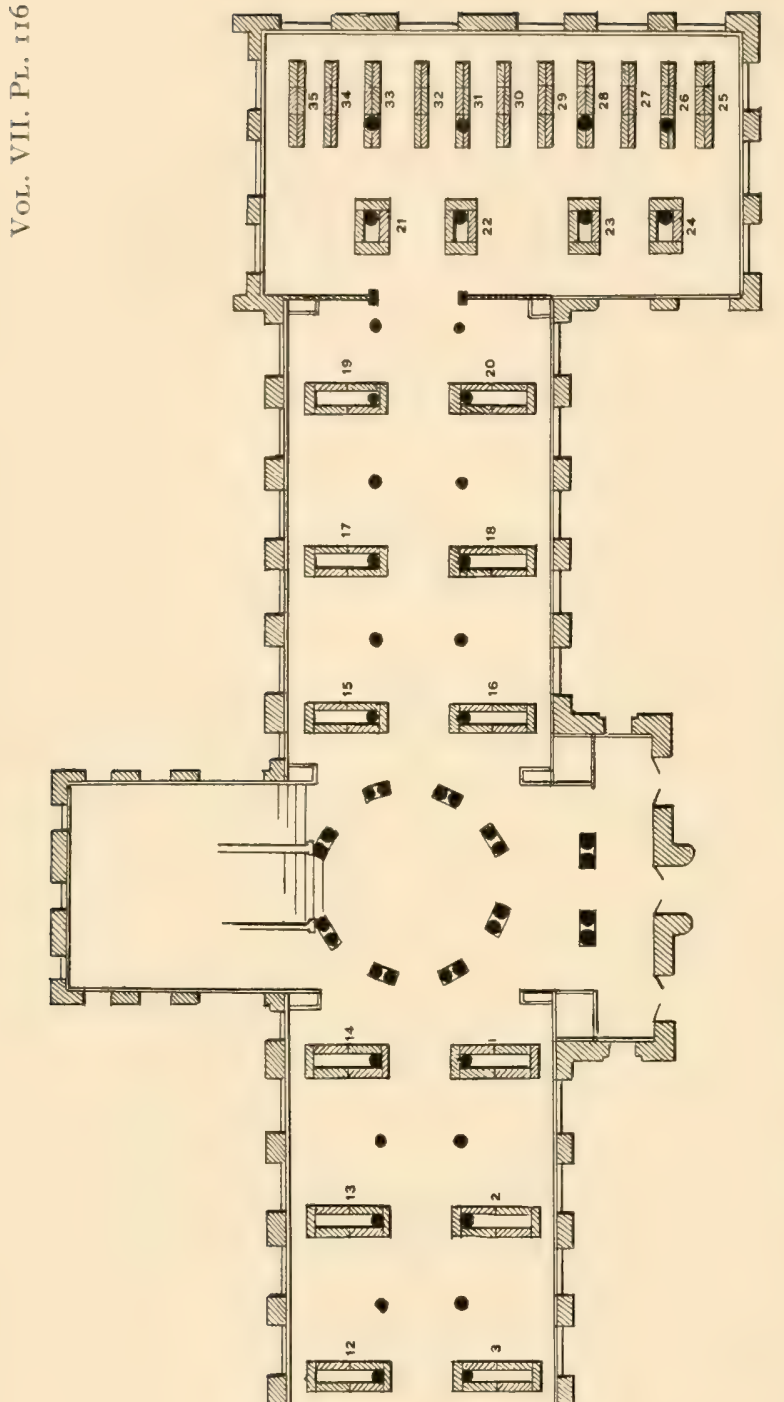

0
$\dot{3}$
$\dot{0}$
$\dot{0}$
$\dot{2}$
$\dot{2}$

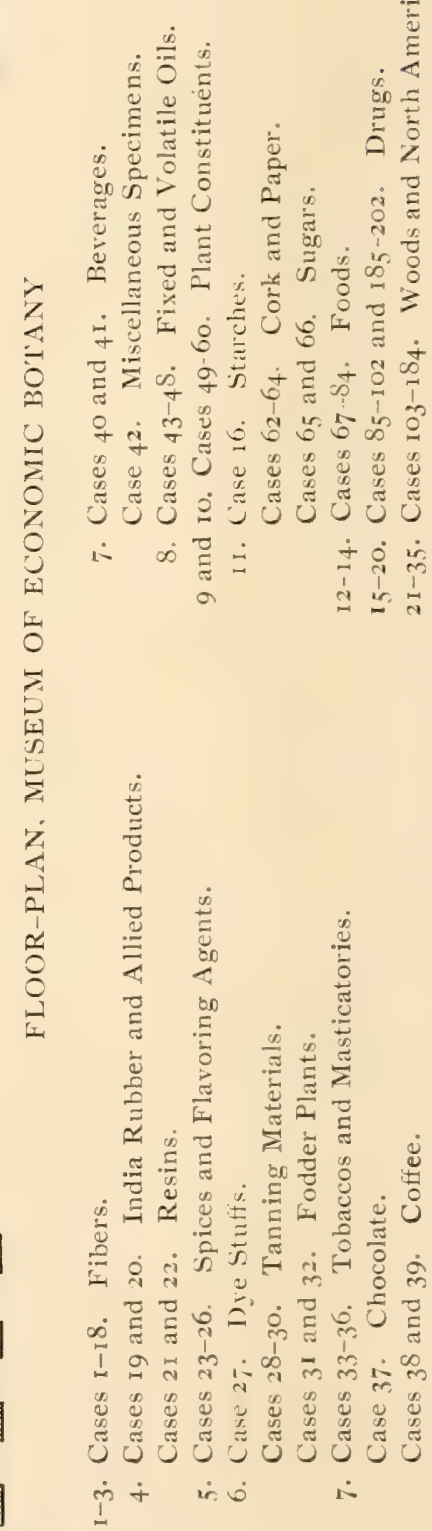


tea, maté or Paraguay tea, Jersey tea and fruit juices, and the alcoholic and malt beverages, as wine, beer, ale and porter. In the block of cases devoted to beverages may be found chocolate, which is derived from the seed of the chocolate tree (Theobroma). The collection shows the chocolate fruits, the principal commercial varieties of the seeds, unroasted and roasted, nibs of different degrees of fineness, germs, cocoa-liquor, cocoa-butter, cocoa-cake, and the same ground into "breakfast"-cocoa, with several varieties of confectioners' chocolate, as put up for the market.

Miscellaneous Specimens. Case 42.-In this case may be seen the substances used in the manufacture of soap, insect powders and related substances.

Fixed and Volatile Oils. Cases 43 to 48 . - The volatile oils form a large series, and in their manufacture various parts of the plants are used; for example, roots are used to make the oils of lovage-root, elecampane and muskroot; rootstocks furnish the oils of calamus, ginger, orris root and wild ginger; herbage is the source of the oils of pennyroyal, tansy, spearmint and peppermint; wood furnishes the material to make the oils of red cedar wood and sandalwood; bark is the source of the oils of birch, cinnamon and sassafras; leaves yield the oils of hemlock, spruce, pine, cedar, eucalyptus and wintergreen; flowers yield the oils of cloves, lilac flower and orange flowers; fruits yield the oils of pepper, lemon, caraway and fennel; seeds furnish the oils of mustard, wormseed, nutmeg and almonds; while resins give us the oils of elemi, mastic, myrrh and frankincense.

The fixed oils, at least from a commercial standpoint, are less numerous than the volatile oils, and those in common use are mostly derived from the fruits and seeds of plants; for example, olive oil is contained in the fruit of the olive, linseed oil is contained in the seed of the flax plant, castor oil is stored up in the seed of the castor oil plant and cotton oil abounds in the cotton seed. Fixed oils differ from volatile oils in not completely evaporating when exposed to the air. In many cases the by-products resulting during the manufac- 


\section{(24)}

ture of the various oils are of considerable commercial importance. Some of these by-products are shown in the cases with the oils.

Plant Constituents. Cases 49 to 6o.-This exhibit consists of a series af alkaloids, acids, glucosides and amaroids, albuminoids, resinoids and enzymes. These substances plants store up in their tissues, or in the tissues of one or more organs, and from them they are extracted for use in all branches of the arts, sciences and industries.

Starches. Case 61.- Starch, as in the case of many other substances, exists in and is consequently derived from the several organs of various plants, for example, the roots of the cassava plant furnish the cassava flour and tapioca, while those of coontie yield coontie flour which is quite similar to sago, and those of the sweet potato plant furnish sweet potato flour. The rootstocks of the common potato plant abound in potato flour, while those of the arrow-root plant yield arrw-root flour. The stems of some of the sago palms and those of some of the true palms are the sources of sago flour. The fruits, both dry and fleshy, of a great variety of plants, contain starch; for example, those of the several grains, wheat, rye and corn; while those of the banana yield the less common banana flour. The seeds of some plants are used as a source of starch, as for instance, those of the chocolate plant.

Cork and Paper. Cases 62 to 64 .-Cork is the light outer bark of the cork oak tree, a tree indigenous to southern Europe. The substance, as we are accustomed to see it, is prepared by means of boiling the cork bark and scraping off the rough outer portion. The crude cork and many manufactured articles are shown in case number 49, and a large jacket of crude cork is exhibited near by, just as it was stripped from the tree.

Wood fiber, especially that obtained from the trunks of the spruce and poplar, enters largely into the manufacture of paper. In cases 48 and 50 , the fiber is shown in its crude condition and in the various stages of refinement, as well as 
the various qualities of paper into the structure of which it enters. Here also are the several stages and substances connected with the production of straw paper.

Sugars. Cases 65 and 66.- Sugar is a very important plant-product and it is of vast economic value. Sugar cane (Saccharum) is the basis of the world's sugar supply. The juice from the stems of the plant is boiled down and by other processes is made into the principal crude products shown in the cases and later into the commercial grades of sugar.

The juices of other plants are also used in making sugar, for example, in temperate regions, the sugar beet yields an enormous amount, the sap of the maple tree is made into maple sugar, while in tropical regions the sap of various palms, such as the cocoanut palm and the sugar palm, is made into palm sugar.

Foods. Cases 67 to 84 .-The very important section of vegetable foods occupies the cases on the north side of the west hall, opposite those containing the fibers. Here may be seen the various plants and parts of plants commonly used for food. In a few instances nearly the whole plant is available, as in the mushroom, the morel and the truffle. Usually, however, certain parts only are nutritious or desirable; a few examples of these are as follows: sweet potatoes, horseradish, carrots and beets are roots; onions, potatoes and Jerusalem artichokes are rootstocks; asparagus and poke shoots are young stems; lettuce, beet-tops, spinach and parsley are leaves; cauliflower and calamus-buds are inflorescences; corn, rice, bananas, mulberries, gooseberries, apples, tomatoes and oranges are fruits; while peanuts, walnuts, hickorynuts, beans, almonds and chestnuts are seeds.

Drugs. Cases 85 to 102 and $\mathrm{I} 85$ to 202.-The east hall is given over to drugs. This, like the department of foods, is large and important. The active principles or medicinal agents are stored up in the tissues of the plant or in special organs. The great majority of refined drugs are derived from one or more of the parts of the plant, but in the case of the white agaric, ergot, Irish moss, Iceland moss, winter- 
green, sundew, bitter-sweet, pennyroyal, boneset and tansy the whole plant is used.

A few of the crude drugs arranged under the several plantorgans they represent are as follows: sarsaparilla, poke-root, rhubarb, aconite, queen's root, senega root, marshmallow, man-in-the-ground and ipecac are roots; calamus, ginger, colic-root, Canadian snake-root, soapwort, mandrake, American ipecac, buckbean and stonewort are rootstocks; sandalwood and quassia chips are woods; sassafras medulla is pith; birch, slippery elm, sassafras, cinnamon, wild cherry, horsechestnut, cascara, linden and cinchona are barks; laurel, hardhack, cherry laurel, peach, senna, coca and eucalyptus are leaves; red-clover flowers, orange flowers, linden flowers, heart's-ease, borage flowers, safflower, marigold flowers, Roman chamomile, German chamomile and milfoil flower are flowers and flower-heads; saw-palmetto, cardamon, cubebs, hops, star anise, poppy, rose hips, tamarind, Tonka bean and colocynth are fruits; colchicum seed, grain of paradise, betel nut, mustard, delphinium seed, almonds, calabar bean, Barbadoes nut, castor oil seed and henbane seed are seeds.

Woods. Cases I03 to I 84. - The east wing is occupied by woods. The exhibits fall under two main divisions, the one consisting of a series of wood-specimens from all parts of the world, and crude wood-products such as pipes, canes, shoes, sandals, utensils and carbons or charcoals; the other being a synoptic collection illustrating North American dendrology.

\section{THE MUSEUM OF SYSTEMATIC BOTANY}

This occupies the entire second floor of the building and is designed to illustrate by specimens, drawings and photographs, types of all the natural families of plants, beginning with those of the simplest structure and ending with the most complex. It consists of three series of objects:

(a) The general synoptic collection.

(b) A series of microscopes showing selected specimens.

(c) Illustrations of the local flora. 



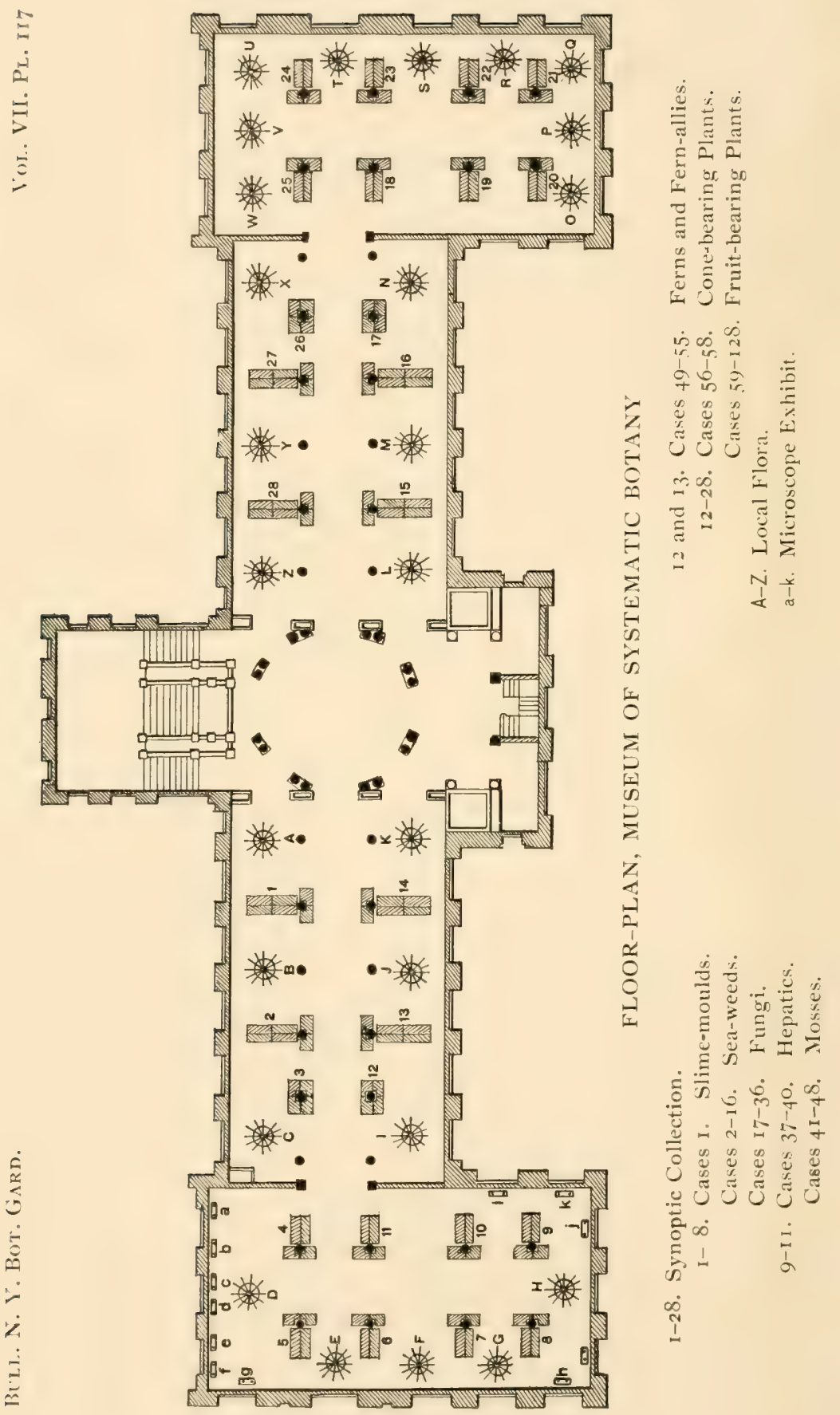


a. Synoptic Collection. This is designed to illustrate the plant world. A series of characteristic objects is installed as a basis for illustrating each plant-family. These specimens are accompanied as far as possible by plates, drawings or photographs, while on the shelves are arranged additional objects, such as flowers, fruits, woods, specimens of fossil plants and models of various organs of plants, all intended further to illustrate the structural characteristics of the different groups. This collection is arranged according to the most natural and thus far most generally satisfactory interpretation of the interrelation of the plant-families; it may be considered as falling into two main series, namely, the flowerless or spore-bearing plants and the flowering or seedbearing plants.

The flowerless plants fall into three subkingdoms: (I) the Thallophyta, in which the plant-body is not differentiated into stems and leaves, represented by the slime-moulds, the bacteria and other micro-organisms, the seaweeds, the fungi and the lichens; (2) the Bryophyta, represented by the mosses and their immediate relatives; and (3) the Pteridophyta, including the ferns and the fern-allies.

The Thallophyta (cases I to 36 ), may be defined as plants without true roots, stems or leaves, but notwithstanding their simple structure they exhibit an infinite variety of form and color.

The Myxomycetes or slime-moulds (case I), standing at the bottom of the plant scale, occupy the first exhibition case placed at the right hand side of the stairway from the main floor. They are thallophytes, having neither chlorophyl nor (in their vegetative condition) a cell-wall. These very simply constituted plants usually grow upon and derive their nourishment from decaying organic substances. They vary greatly in size, some being exceedingly minute, others assuming the form of relatively large irregularly shaped masses spreading in all directions as they grow. Most of the plants are small, and the structure is very delicate, in fact some are so fragile that a mere breath of air will ruin them. 
Following the slime-moulds stand the cases devoted to the algae or seaweeds (cases 2 to I6), which may be briefly defined as thallophytes with chlorophyl, the green coloring matter of plants. The plants of this series are much more variable in form than those of the preceding, and are also much more numerous. Some forms are microscopic, others attain considerable size. The first case of the series is occupied by representatives of the blue-green algae (case 2) and the diatoms. The plants of these two groups are minute, so much so that in most cases the individuals can be well seen only with the aid of a microscope. As one finds them in nature they commonly form slimy or oozy masses which are not particularly attractive to the naked eye, but under a compound microscope they are of very great interest. Following the series just mentioned are the green seaweeds (case 3 ), the group which includes the plants that are sometimes called the pond-scums, green slimes, green felts and stoneworts. Some of these are microscopic; however, some of the green seaweeds attain a considerable size and begin to look a little more like what are popularly termed "plants." After the green seaweeds come the brown ones (cases 4 to 8 ), and here the largest kinds are included. In their tissues is found a brownish pigment which obscures their green coloring matter. To this group belong the widely distributed "gulf-weed" or "sargasso-weed" (Sargassum) and the gigantic "great kelp" of the Pacific Ocean, which is said to attain seven hundred feet in length. The seaweeds culminate in the red algae, a group in which the plants show some shade of red, pink or purple; these (cases 9 to 16 ) exhibit a marvelous range of form and color. The last group of cases containing this series is given to the group of red algae which are known as the corallines, on account of their outward resemblance to the corals. These plants are thoroughly permeated with lime and are often as hard and stone-like as any coral, and build up reefs in the tropical oceans much as the corals do.

The next great type of plant life is the fungi (cases 17 to 36). These, like the plants of the preceding group, vary 
greatly in size and complexity of structure; but, unlike them, they are devoid of chlorophyl, the characteristic green matter which enables other plants to build up complex food for their nourishment, and consequently they are wholly different in their mode of life. Some are parasitic, deriving their nourishment from living plants and causing enormous damage to crops; others are saprophytic, deriving it from the remains of dead organisms; while others are symbiotic, living in such relationship with chlorophyl-bearing (green) plants that they mutually nourish one another, as in the case of lichens and mycorhizas. There are five generally recognized series here: First we have the stalked-spored fungi (cases ${ }^{7} 7$ to 28). This series falls into two groups, the one typified by the "rusts" and "smuts" which are commonly parasitic on the leaves and fruits of other plants; the other the great saprophytic group, well known through the mushrooms, bracket-fungi, stink-horns and puff-balls. Second in the series is the group known as the imperfect fungi (case 29). In this group the spores are borne directly on the threads or "hyphae" which constitute the vegetative portion of the organism. They are often parasitic on the leaves and on the bark of both wild and cultivated plants. Third in this series are the spore-sac fungi (cases 30 and $3 x$ ). In these plants the spore are borne in delicate membranous sacs, called asci, which in the more complex forms are collected into bodies of various shapes. The plants vary greatly in size and structure and are both parasitic and saprophytic. To this group belong the yeasts and mildews. Some plants grow above the surface of the ground, as in the case of the morel; while others are subterranean, as in the case of truffles. Next in order are the alga-like fungi (case 32); these vary in form from simple masses of protoplasm to simple or branching threads. Here belong many of the moulds and similar forms which grow both on other plants and on animals. The fifth and in many respects the most interesting of all the groups is that consisting of the lichens (cases 33 to 36 ). The fungi thus far considered are either parasitic 


\section{( 30$)$}

or saprophytic in their mode of life; the lichens form an independent symbiotic group, each lichen consisting of a fungus and an alga living together, the one nourishing the other. The lichens are quite familiar to most people as plants of more or less leathery texture growing on rocks, on poor soil or on the trunks of trees.

A step forward brings up to the Bryophyta, or seedless plants with roots, stems and leaves, but without vascular tissue (cases 37 to 48 ). This group is best known through the mosses, which form its largest division; but of simpler structure are the hepatics or scale-mosses (cases 37 to 40 ) ; although they were formerly associated with the true mosses, their tissues are much less differentiated than those of the mosses and the structure of their various organs much less complicated. The stems and leaves of the hepatic plant are sometimes combined into a flat thallus-like body which creeps closely on the ground or other objects and resembles in aspect some of the more simply organized plants. The leaves, too, are more like scales than in the true mosses and they do not have a midvein. These differences alone enable one to distinguish a hepatic from its relatives by the unaided eye or at most by the use of a lens. In addition to these characters, the capsule or the receptacle which bears the spores, or reproductive bodies, usually splits into four valves when full-grown and the spores themselves are accompanied by spiral threads called elaters. The favorite habitat of hepatics is wet places, and mountains continually steeped in clouds yield a surprising variety of forms. Closely related to the hepatics is the group Anthocerotes; these plants may, however, be distinguished by the presence of a central axis or column (columella) in the capsule, and there are several other important structural differences in their tissues.

The mosses (cases 4 I to 48 ) follow the hepatics in order of development and complexity; they differ from them, however, in many respects. The stem and leaves have more differentiated tissues, and the leaves usually have a midvein. The moss capsule generally opens by a lid under which there are 
commonly appendages to aid in scattering the spores, which in this case are not accompanied by spiral threads as they are in the hepatics. The mosses fall into three primary groups: First the "peat-mosses" (Sphagnum) which differ from the rest of the mosses in the development of the tissue-structure of the capsule and the spores; they grow in swamps and other wet places, and their accumulation forms peat. The "black mosses" (Andreaea) differ from both of the other groups in the valvular capsule; they grow on dry rocks. The true mosses vary exceedingly in size and aspect. An examination of the specimens in the exhibition cases will convey to the mind a better idea of this group than a description. They grow under all kinds of conditions from dry rocks to deep water. Many of the kinds grow on almost any kind of rock, earth or bark of trees, while certain ones are more particular as to their habitat. Some will thrive only on limestone, which they often gradually disintegrate and partially preserve in the masses of closely set plants as a calcareous tufa; other species prefer ground that has recently been burnt over, as species of Funaria and Leptobryum, while others grow only on the bones of dead animals or in places where animal refuse has accumulated.

Next higher in the plant kingdom is the subkingdom Pteridophyta, or ferns and fern-allies, the seedless plants with roots, stems, leaves and woody tissue (cases 49 to 55 ). The ferns as a group perhaps attract the attention of a greater number of people than any other group of plants. However, associated with what are usually known as ferns are the fernallies, for example the "horse-tails" (Equisetum), "lycopods" (Lycopodium) and "quillworts" (Isoetes), but these are usually less conspicuous than the "ferns." Fern-plants differ from all the plants of simpler organization in having vascular (woody) tissue, that is, a system of vessels for conducting sap through the different parts of the plant-body. They exhibit an almost infinite variety of form; their stems may be underground, horizontal on the ground, or erect; the leaves are either simple or compound, and sometimes perform 
both the work of foliage leaves and that of bearing the sporecases (ferns), while in other cases some of the leaves have become changed into mere spore-bearing organs (horse-tails).

The flowering plants (cases 56 to 128 ) comprise a single subkingdom, the Spermatophyta, or seed-bearing plants. This extensive group seems to have followed two independent lines of development and consequently the plants fall into two well marked groups, the first being the gymnosperms, cone-bearing plants, or plants in which the seeds are borne exposed in variously shaped cones (cases 56 to 58 ). This is a comparatively small group, but exhibits great diversity, including plants ranging from straggling shrubs or vines to the largest trees. The leaves, too, vary from structures resembling needles or scales to expanded fern-like structures of considerable variety. In a former geological age these plants were the dominant seed-bearing plants, but now the second group of the spermatophytes largely predominates; namely, the angiosperms, fruit-bearing plants, or plants in which the seed is borne in a seed-case. These plants also existed in the later geological ages, and now form the most important and conspicuous part of the vegetation of the earth. The fruit-bearing plants (cases 59 to I 28 ) fall into two divisions, the one in which the seed contains a single leaf, the monocotyledons (cases 59 to $7 \mathrm{I}$ ); the other in which the seed contains two leaves, the dicotyledons (cases 72 to I 28 ).

b. Microscope Exhibit. The exhibition microscopes occupy small stands in the west wing of the second floor. In front of the windows on the right as one enters the wing are shown a few of the simplest and smallest forms of plant life. Under the first microscope is a preparation showing the vegetative condition of one of the slime-moulds, organisms in which the characteristics of plant and animal are so little differentiated that it is nearly impossible to affirm with confidence that they belong either to the one kingdom or to the other. In the vegetative stage - the stage here exhibited - the organism is strikingly similar in its essential attributes to some of the lower animals. Later, in the reproductive stage, 
there is at least a superficial resemblance to the fungi, which are undoubted plants. By means of the second microscope the spore-bearing stage of a slime-mould may be seen. The stalks and the netted framework of the spore-case walls remain, but the spores have mostly fallen. A few of the spores, however, appearing like minute dark dots, can be detected, adhering to the network. Under the lenses of the third microscope are representatives of the diatoms-onecelled organisms, some of which have the power of animallike locomotion. The living substance of each cell is enclosed and protected by a hard transparent glassy wall consisting of two halves, one of which fits into the other like a bandbox into its cover. Following this are shown "sea mosses," or "seaweeds," as they are commonly known, and closely related minute plants which inhabit fresh water and belong to groups often referred to in popular speech as "pondscums" or "ooze." In the natural unmagnified condition, many plants of this sort seem quite the reverse of attractive, but when placed under a sufficiently powerful microscope many of them reveal a rare beauty. The "sea mosses," or "seaweeds," gradually lose much of their natural beauty of coloration on prolonged exposure to the light, but the pervailing elegance and symmetry of form and structure persist.

Following the plants of the seaweed type are several representatives of the smaller fungi. The specimens exhibited are chiefly from among those which grow upon decaying organic refuse. One interesting parasite exhibited is a fungus parasitic upon another fungus, which, in turn, is a parasite on the leaves of the common lilac. Another fungus shown lives chiefly within the cells of the underground parts of one of the orchids, yet it can scarcely be called a parasite, inasmuch as its presence in the tissues of the orchid is beneficial to the orchid as well as to itself. Of the fungi which live upon deceaying refuse matter, Ascobolus is one of the more interesting among those selected for exhibition. In this, the spores, or propagating cells, are borne in groups of eight within transparent ellipsoidal sacs, and at maturity these 
sacs, each enclosing eight spores, are ejected with considerable force. Under two microscopes are shown sections of lichens, illustrating their mode of reproduction and the fact that a lichen consists essentially of two organisms, a fungus and an alga, intimately associated and-constituting what for many purposes may be looked upon as a single organism.

Then follow specimens of the liverworts or scale-mosses, plants in which the differentiation of the vegetative body into stem and leaves becomes first clearly evident. One of these, a Frullania, has a part of each leaf peculiarly modified so as to form a reservoir for water. By aid of this derice, the frullanias and their allies are able to thrive in drier situations than are in favor with most of the order to which they belong. Preparations are exhibited showing also the regetative structure and methods of reproduction of the true mosses. Especially interesting is the "peristome" of one of the mosses, which is a fringe of peculiar appendages surrounding the mouth of the little urn in which the minute dust-like spores are borne. These appendages move about as a result of changing conditions of moisture and these mechanical movements assist in scattering the spores. A somewhat analogous device is found in connection with the spores of the equisetums or horse-tails, though the appendages in this case are attached to the spores. Following the slide illustrating this feature of the horse-tails is one showing the spores and spore-cases of the common polypody. The sporecase here is provided with a sort of spring, by the action of which the spores are violently ejected, catapult-fashion. The remaining preparations show the structure of the leaf-stalk and root of common types of ferns.

c. Local Flora. In this collection it is designed to illustrate every plant-species growing naturally or without cultivation within one hundred miles of New York City. For the most part specimens of the plants themselves are used, but in cases where the structure of the plants renders this method undesirable, or impossible, a photograph or a drawing is substituted for the plant-specimen. This collection 
• 

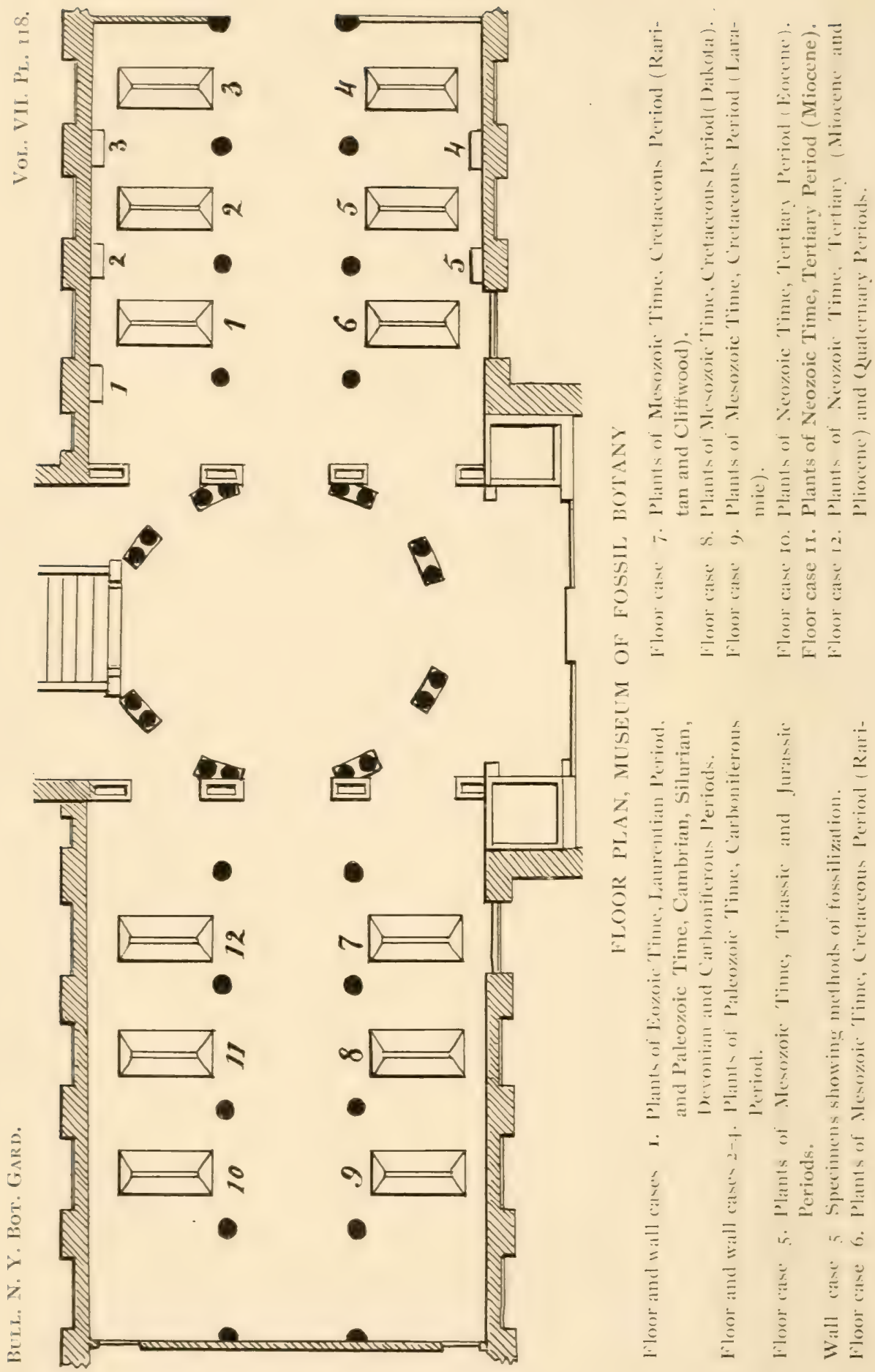

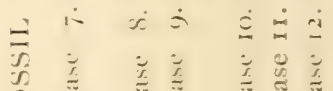

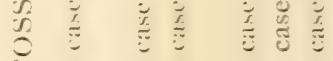

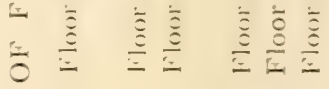

$\Sigma$

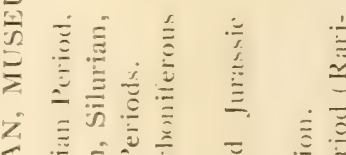

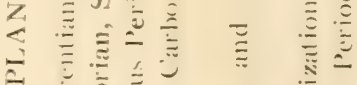

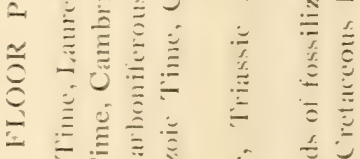

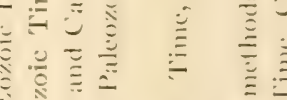

三

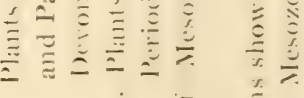

- $\quad \div \quad \bar{\equiv} \equiv$

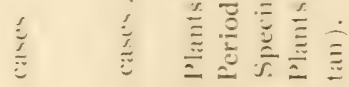

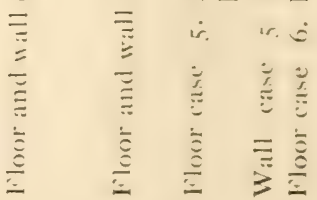


is displayed in swinging frames which are placed so as to correspond in a general way to the sequence of the cases of the synoptic collection already described; thus, the first stand is near the first museum case as one enters the west hall from the top of the staircase. All of the plant groups are here represented by those members that occur locally, and the characteristics of the several groups as mentioned under the Synoptic Collection also apply here.

\section{THE MUSEUM OF FOSSIL BOTANY}

This collection, installed in the basement, is designed to show the successive stages of evolution through which the ancestors of our living flora have passed since the time of the first appearance of plant life on the earth, as far as the remains of extinct plants have been preserved. The general arrangement adopted is therefore based upon the sequence of the geological time divisions: Eozoic, Paleozoic, Mesozoic and Neozoic, and their subdivisions into periods; Laurentian, Cambrian, Lower Silurian, Upper Silurian, Devonian, Carboniferous, Triassic, Jurassic, Cretaceous, Tertiary, Quaternary and Modern. This arrangement is therefore geological, but incidentally it is also biological, and follows the same system as that on which the synoptic collection of the museum of systematic botany is arranged, inasmuch as the plants of the earlier periods are low in the scale of life, consisting of thallophytes and pteridophytes and plants of uncertain botanical determination, while those which appear in the successively later periods are of successively higher and more complex types, represented by cycads, conifers and both monocotyledonous and dicotyledonous plants closely related to our living flora.

The series of exhibits begins in the first cases to the left as one enters the east hall of the basement. The sequence of the specimens in the wall cases corresponds to that of the floor cases.

In floor- and wall-cases Nos. I to 4 may be seen representatives of Eozoic and Paleozoic Time: Laurentian, Cambrian, 
Lower Silurian, Upper Silurian, Devonian and Carboniferous Periods. In floor- and wall-case No. I are specimens of graphite of eozoic age and of anthracite and bituminous coal of carboniferous age, showing the transformation of vegetable matter into the ultimate condition of pure carbon in the form of graphite or "black lead" in the oldest rocks. Other specimens in this case, classed as algae, are of uncertain botanical relationship, as the structure of the primitive plants was not well adapted for preservation as fossils. For example, some organisms appear as mere filamentous strips of graphite in white limestone, without any trace of the original structure remaining, while others may be seen as casts and impressions which closely simulate in general appearance different parts of the seaweeds now existing. In this series of problematic fossils are also included a number of forms at one time definitely classed as plants but now by some assumed to be of animal or inorganic origin; namely, Scolithus, which may be caused by worm burrows; Phytopsis, which may be a coral; Plumalina, which may be a hydroid; Dendrophycus, which may be current-markings; and Dictyolites, which are most likely sun-cracks. All of these, however, have at one time or another been definitely regarded as the remains of marine plants and were originally so described and classified.

In these cases and in wall-case No. 2 are also the remains of the earliest fern-plants and their allies (Pteridophyta) of Devonian and Carboniferous age, represented by Lepidodendron, Sigillaria and Calamites, and the early seed-bearing plants, the cone-bearers (Gymnosperms), represented by Cordaites, with the fossils under Trigonocarpon, Rhabdocarpon and other genera.

Floor-cases Nos. 2 and 3 and wall-case No. 3 contain specimens of Carboniferous age, for the most part ferns or fern-like plants, which were originally described as ferns, but which are now placed in a different group, the Cycadofilicales, that is, plants that had characteristics of both the ferns and the sago-palms, but more closely related to the latter than to the ferns. 
Floor- and wall-cases No. 4 are devoted to specimens of Carboniferous plants in the genera Lepidodendron, Sigillaria and Stigmaria, in order to show the variation in the arrangement and shape of the leaf scars and the difference between specimens with the bark preserved and those which have been decorticated.

Floor-case No. 5 contains types of early Mesozoic time: Triassic and Jurassic Periods. - The plant remains in this case are mostly sago-palms or cycads, with a few cone-bearers and fern-plants, besides specimens of the so-called "Glossopteris flora," a flora of uncertain botanical relationship, which flourished in the transition period between Paleozoic and Mesozoic time, particularly in the southern hemisphere, and may yet be represented by the living South African genus Stangeria, a cycad having leaves with pinnately arranged forking veins, similar to ferns.

Floor-case No. 6 embraces plant remains from the rocks of later Mesozoic time: Lower and Middle Cretaceous Period.-These specimens represent the first appearance of the higher seed-bearing plants (Angiosperms), the type which is dominant in the existing flora. The genera are in most instances apparently identical with those now in existence, but the species are extinct. The plants of the Lower Cretaceous consist largely of ferns and cone-bearers, while those of the Middle Cretaceous show a preponderance of angiosperms. Floor-case No. 7 is arranged to show specimens of the Middle Cretaceous flora found within the limits of the City of New York, on Staten Island, or in the immediate vicinity, in New Jersey and on Long Island.

Floor-case No. 8 contains specimens from the Middle Cretaceous of the western States. Those from the Dakota Group are exceptionally fine, many of them being perfectly preserved and showing both cast and impression of the same leaf as counterparts.

Floor-case No. 9 is devoted to plants of the Upper Cretaceous (Laramie Group), and completes the vegetation of Mesozoic time. 


\section{$\left(3^{8}\right)$}

Floor-cases Nos. Io to 12 and wall-case No. 5 contain plant remains of Neozoic time. Those of the early Tertiary Period (Eocene) are displayed in floor-case No. Io. Those of the later Tertiary (Miocene) and Quaternary Periods in floor-cases Nos. I I and I 2. The specimens in the latter case complete the sequence of plant life on the earth and bring it up to modern times. A number of specimens at one end of the case show the methods of preservation by petrification, incrustation and carbonization, and on the upper shelf is a series of specimens from Quaternary and more recent swamp deposits which show how the conversion of living plants into fossils, a process now going on, has its beginning.

The specimens in wall-case No. 5 further illustrate the characteristics of the plants of the late geological periods and the methods by which the various plant structures have been preserved. A number of specimens of silicified woods show the method of preservation by what is known as petrifaction, or conversion into stone, in which the woody structure is replaced by mineral matter. Other specimens show preservation by incrustation, in which mosses and the stems of reeds are coated or incrusted by mineral matter deposited from springs; while on the upper shelf and on the top of the case are logs and stumps from old swamps and interglacial deposits, in which the wood has been partially carbonized, or converted into lignite, by the slow process of natural distillation. This process represents the beginning of the conversion of vegetable tissue into coal.

\section{LECTURES}

Other features of the museum building include the large public lecture hall, with a seating capacity of over seven hundred, which occupies the western end of the basement. It is equipped with an electric projection-lantern, and public popular lectures covering a wide field of botanical and horticultural subjects are delivered here on Saturady afternoons in autumn and spring; these are fully illustrated by means 



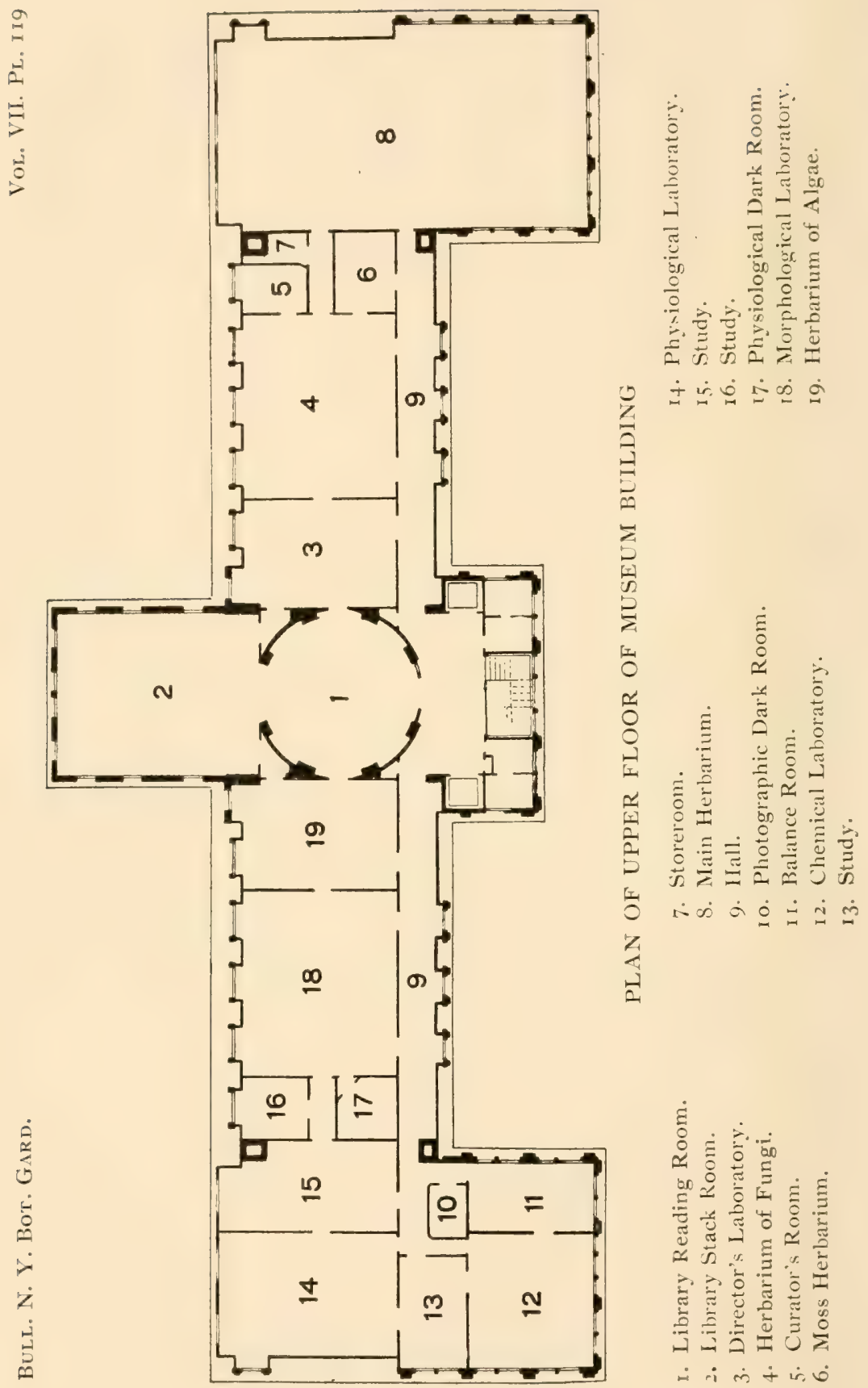


of a very extensive collection of lantern slides owned by the Garden which is constantly being increased; a noteworthy part of this collection is the series of delicately and accurately. colored slides of flowers, fruits, trees and shrubs, by Mrs. Adelaide S. Van Brunt, from photographs made during many years by her late husband, Cornelius Van Brunt.

A series of lectures to the pupils and teachers of public schools, designed to illustrate and supplement their work in nature study, is given in the large lecture hall on afternoons in autumn and spring, and these lectures are attended by many thousand children.

The Horticultural Society of New York holds several of its monthly meetings at the Garden, using the large lecture hall, and also uses the basement museum hall adjacent for the purpose of exhibitions.

The Torrey Botanical Club holds monthly meetings from October to May, on the afternoon of the last Wednesday of each month, in the museum building, and many of its field meetings on Saturday afternoons throughout the season are held at the Garden.

\section{THE LIBRARY}

The library of the Garden is located in the center of the upper floor of the museum building, and is available for consultation, by permission. It has been formed by the Board of Managers in order to provide for the use of students, all the literature of botany, horticulture and related sciences, and is rapidly becoming one of the most complete collections in the world of books and pamphlets dealing with these subjects.

\section{THE HERBARIUM}

The herbarium consists of dried specimens of plants systematically arranged in cases; it occupies the greater portion of several rooms on the upper floor of the museum building, and is available for consultation by permission. It contains prepared specimens of all kinds of plants from all quarters of the globe, and is the most extensive and complete collection of its kind in America. 


\section{THE LABORATORIES}

Laboratories and working rooms for research are provided on the upper floor of the museum building, and properly qualified students of botany are permitted to make use of this equipment, under the direction of some member of the staff of the Garden. The equipment is designed to meet the needs of a very broad field of investigation including plant chemistry, pathology, physiology and morphology. A valuable series of old microscopes, illustrating the history and development of that instrument, has been presented by Mr. Charles F. Cox.

\section{The Pinetum}

\section{[COLLECTION OF CONE-BEARING TREES]}

The collection of cone-bearing trees, technically known as the Pinetum, because the pines are the most abundant of these trees, is planted over a space of about 30 acres in the southwestern part of the grounds, extending from the approach to the elevated railway station southeast to the herbaceous garden, and northeast to the museum building and the borders of the hemlock forest. The species of trees are grouped in genera, as shown by the accompanying plan. The planting out of these trees was commenced in I9OI, and, as rapidly as the finished grades of this portion of the grounds have been established and the driveways and paths completed, additional planting has been done; the collection will continually become more complete year by year as additional species are secured; many of these have to be raised from seed, and the process of establishing a collection of conifers thus requires much time.

Commencing at the approach to the elevated railway station we find the Douglas spruce (Pseudotsuga mucronata) planted in the space between the traffic road and the park driveway to the left of the path leading to the Conservatories; this tree is a native of western North America from the Rocky Mountains to the Pacific Coast and is sometimes known as 
red fir. In the far northwest it sometimes becomes 180 to 2 Io feet high, its trunk occasionally as much as $3 \mathrm{I} / 2$ feet in diameter, but in the Rocky Mountains it is seldom onehalf this size, and trees taken from the far northwest do not thrive well on the Atlantic coast, owing to the much greater rainfall which they naturally receive there; the cones of the Douglas spruce are from 2 to 4 inches long, pendant on the branches, their scales rounded and shorter than the bracts which project beyond them.

The hemlock spruces (Tsuga) are planted between the approach to the elevated railway station and the power house, and are represented by the Canadian hemlock spruce (Tsuga canadensis), the same species which forms the interesting forest on the hills bordering the Bronx River, and indicated on the general plan of the Garden as the hemlock grove. This tree occasionally becomes about 90 feet high, with a trunk up to 12 feet in diameter, and is distributed throughout northeastern North America, extending southward along the mountains to Alabama, northward to Nova Scotia and westward to Minnesota. Its bark is the most important tanning substance in the United States and a great many trees are annually felled to obtain it; its wood furnishes a cheap lumber of little strength and durability. The Carolina hemlock (Tsuga caroliniana), from the mountains of southern Virginia to Georgia, may also be seen here, as well as the Japanese hemlock spruce, to which the name Tsuga was first applied.

In the area to the westward of the conservatories, and bounded by the surrounding paths, are the firs (Abies). These can at once be distinguished from the spruces (Picea) by the erect, instead of pendulous, cones, and by the smooth branchlets. The wood of the firs is usually soft and not durable, so it makes poor lumber. Specimens of the balsam fir will be found here; this is widely distributed over northern North America, and from it is obtained canada balsam or balm of fir, used in the arts and in medicine. The Japanese silver fir is an attractive plant, with its dark green stiff 
foliage. Veitch's silver fir, from Japan, and said also to occur on the neighboring coast of Manchuria, is one of the best for ornamental purposes. It was discovered in I 860 on the famous Japanese mountain, Fuji-yama, by Mr. Veitch, for whom it is named. The red fir, from Washington and Oregon, with its blue leaves, borne almost erect and apparently on but one side of the branchlets, makes a conspicuous object. In its native country it sometimes attains a height of 250 feet. Its wood is sometimes used in the interior finishing of buildings. Among other firs here are: the white fir, from western North America, sometimes growing to a height of 200 to 250 feet; the Siberian fir, from northern Europe and Asia, yielding a soft lumber in general use and a bark used in tanning leather; the common silver fir, from Europe; Nordmann's silver fir, from the Caucasus; the Sicilian silver fir, from Asia Minor; and the Nikko silver fir, from Japan.

The spruces (Picea) are located in the area to the northeast of the firs. Some of the spruces are most valuable timber trees. The oriental spruce, from Asia Minor, is present in several specimens. One of the hardiest spruces for our climate, and a general favorite, is the Colorado, or blue, spruce, the young foliage of which has a decided blue color, whence its name. It usually grows about roo feet tall in its native country. The Norway spruce, with a number of horticultural forms, makes a group on the highest portion of the area devoted to the spruces and is a commonly cultivated tree. It furnishes a useful timber, which is known as "white deal" in England, and is largely used in the manufacture of musical instruments. The resinous exudation of this tree is known as Burgundy pitch, which, in combination with other ingredients, is used in Germany to line beer casks. Other spruces of interest here are the Yesso spruce, the wood of which is much used in Japan; the white, or Engelmann's, spruce, from western North America, the wood of which is largely manufactured into lumber and the bark sometimes used in tanning; the Servian spruce, one of the largest and most valuable timber trees of Europe; and the tiger's-tail spruce, from Japan, 

introduced about forty years ago, and one of the hardiest Asiatic species in cultivation.

The space allotted to the pines (Pinus) embraces the region to the eastward of the spruces and public conservatories, extending across the road to the herbaceous grounds. Most of the pines are of great economic importance, furnishing large quantities of lumber, turpentine and resin. Most of the white pines will be found on the westerly ridge of the herbaceous grounds and across the road from this to the eastward of the conservatories. Among these is our common white pine and several of its horticultural varieties. It is perhaps the most valuable of the timber trees of northeastern North America, large quantities of lumber being derived from it; near this is the Himalayan pine, resembling it, but with longer leaves. This sometimes attains a height of 150 feet in its native country, where its lumber is much used for building and other purposes. In this region will also be found the Cembra or Swiss stone pine, of southern Europe and northern Asia; and the Macedonian pine, of southeastern Europe.

In the area to the eastward of the conservatories will be found, among others, the Corsican pine, with a hard, strong wood which is much used; the variegated Scotch pine, with the young leaves variegated; and a number of plants of both the white pine and Himalayan pine.

In the region to the north of the white pine tract, and on the westerly side of the herbaceous grounds ridge, will be found the Tyrolese mountain pine, from the Tyrolese and Venetian Alps, forming a group of some dozen plants; near this is the Japanese red pine, and two horticultural forms of it, from Japan. Following these to the north are a number of plants of the Jack pine, or Banks' pine, native of northern North America. Its wood is sometimes used for fuel, and was valued by the Indians for the frames of their canoes.

In the area to the eastward of the spruces are a number of other pines. The Corean pine, one of the white pines and a native of eastern Asia, is located next to the spruces. Near 
this is the Table-mountain pine. On the high ground to the eastward of the above is the Scotch pine, the principal timber pine of Europe and Asiatic Russia. On the easterly slope of this higher land and on the lower ground nearby may be found, among others, the red or Canadian pine, from northeastern North America, the wood of which is largely used for building purposes and for masts, piles and spars; the small-flowered pine, another of the white pines and from Japan, where it is frequently used by the Japanese in producing their miniature trees; the Japanese black pine, also from Japan and useful for its wood; the Austrian pine, found native in Austria, Servia and Roumania; and the yellow, or bull, pine, from western North America.

In the triangle located midway between the south gate and the conservatories, are the American cypresses (Taxodium), in two species: the cypress, or bald cypress, and the pond cypress. These, like the larches (Larix), and a few other coniferous trees, shed their leaves for a portion of the year. They form vast areas, in parts of the southern states, called cypress swamps. Their timber is of economic importance and their bark is rich in tannin. None of the true cypresses (genus Cupressus) are hardy with us.

At the northern end of the swale in which the herbaceous grounds are located, is a miscellaneous collection of coniferous trees, and also the members of the yew family (Taxaceae). Among the miscellaneous coniferous trees here are: the Japanese cedar, a tree which is barely hardy in this latitude; the umbrella pine, from Japan, a very decorative plant; the deodar, or Indian cedar, from the Himalayan region; and the Mt. Atlas cedar, from northern Africa. The larches (Larix) may also be found in this neighborhood, on the ridge. These are deciduous trees, the wood of which is of great economic importance. Specimens of the European larch are here, and also of the Japanese larch. The genus Pseudolarix, distinguished from the larches in having the scales of the cones deciduous, is represented by its single 
species, the golden, or Chinese, larch; this, like the true larches, is a deciduous tree.

The yew family (Taxaceae) is represented by two genera. Of the true yews (Taxus), there are: the American yew, or ground hemlock; the English yew and several of its horticultural forms, the wood of which was highly prized in ancient times for the manufacture of bows; and the Japanese yew. The cluster-flowered yew (Cephalotaxus) is represented by Fortune's cluster-flowered yew, from northern China, and the iraga boku, of the Japanese, from Japan. Other representatives of this group will be found in conservatory houses Nos. I 2 and I 3 .

On the westerly corner of the conservatory terrace and in the immediate vicinity are located the retinisporas, which are so commonly cultivated as decorative plants. There are many horticultural forms here represented, but they are all variations of two Japanese trees: the Sawara cypress (Chamaecyparis pisifera); and the Hinoki cypress (Chamaecyparis obtusa). The latter species is frequently used by the Japanese in their dwarfing process. The names borne by the various horticultural forms have been suggested by some peculiarity in coloring or in manner of growth. Other species of the genus Chamaecyparis will be found in the low ground along the south walk, not far from the south gate.

On the easterly corner of the conservatory terrace, opposite the retinisporas, is a part of the juniper, or red cedar (Juniperus), collection. The remaining and larger portion of this collection will be found on the easterly end of the area lying between the driveway and the traffic-road south of the conservatories. In these two regions will be found many species and varieties of these plants. The common juniper, of north temperate regions, is one of these; also the Irish juniper, a form of this, of compact and strict habit. The red cedar, so common in a wild state in the grounds of the Garden, finds representatives in many horticultural forms. The low cedar, of North America, Europe and Asia, is a pretty dwarf species. The savin juniper, of Europe and 
northern Asia, and its American representative, the prostrate juniper, of northern North America, are both neat low-growing sorts. The Chinese juniper, and its striking form, of columnar habit, known as variety pyramidalis, are each present in a number of specimens. There are still other varieties of the Chinese juniper represented her.

At the westerly end of this same area is the arbor vitae (Thuja). The species of this genus produce a durable wood, which is of especial value where there is contact with the soil. The Japanese arbor-vitae is represented by a single specimen. The common arbor-vitae, or white cedar, from northeastern North America, is fully represented, not only by the typical form, but by many horticultural varieties, some of them very decorative. The wood of this tree is valued for fence posts, railway ties, etc., and from its young branches fluid extracts and tinctures are made which are used in medicine. The Chinese arbor vitae, from China and Japan, has a number of specimens representing it and some of its horticultural forms.

The maiden-hair tree family is represented by a single species, the maiden-hair tree, several specimens of which may be found on the southern portion of the westerly ridge of the herbaceous grounds. This interesting tree, with its fanshaped leaves, is a remarkable relic of a type of vegetation which was common and widely distributed in tertiary geological time, but is now restricted to eastern temperate Asia in this one species, Ginkgo biloba.

\section{The Herbaceous Grounds}

The collection of hardy herbaceous plants is situated in a valley southeast of the public conservatories, and between the main driveway and the western border of the woods fringing the hemlock grove. This valley is about 500 meters long and averages about 100 meters wide. A small stream runs through the valley from north to south and is here and there broadened out into pools. The collections are arranged 


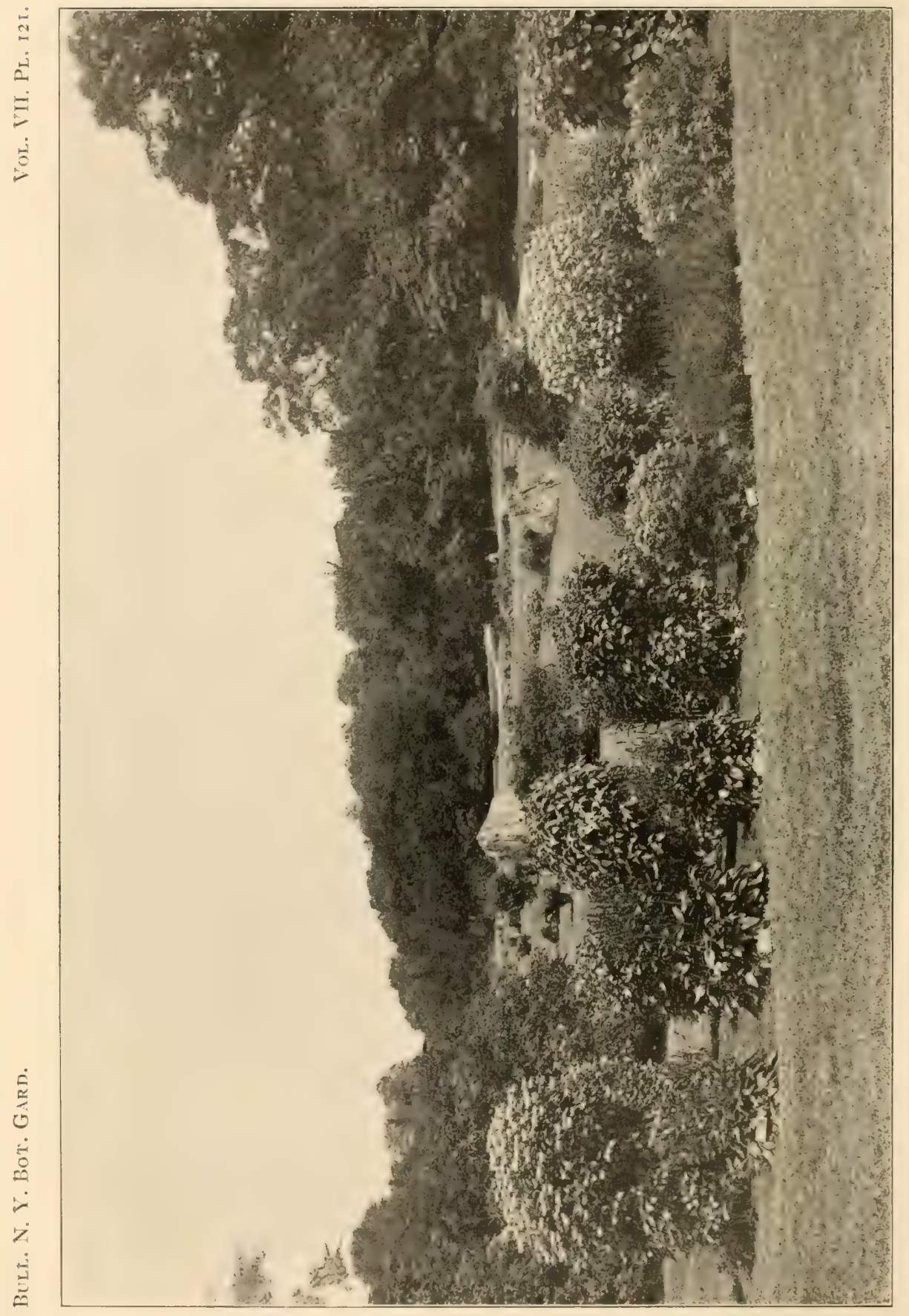

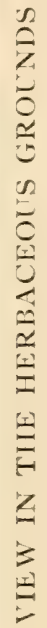


in four series: (a) The systematic plantation; $(b)$ the morphological garden; $(c)$ the economic garden; $(d)$ the viticetum, or collection of vines, both woody and herbaceous, planted at an arbor just east of the northern part of the valley.

\section{(a) Systematic Plantations}

This is located in that portion of the valley south of the driveway crossing it, and here the plants are grouped by natural families in botanical relationship. To the east of the brook are the seedless plants, represented by the ferns and their allies, and the families of seed-bearing plants belonging to the large endogenous division, or those with parallel-veined leaves and with one seed-leaf (monocotyledons). To the west of the brook are the families belonging to the exogenous division of plants, or those in which the leaves are usually netveined and which have two seed-leaves (dicotyledons). This latter group embraces the larger part of the plants in the collection. Along the brook, or in it, may be found many aquatic plants, representing in some cases families which are exclusively water-lovers, while in other cases they are aquatic representatives of families occurring in the immediate vicinity in the beds. In this plantation, the family groups are arranged substantially in a sequence beginning with those of simpler organization and proceeding to the most complex.

The series commences in the southern corner of the valley at the foot-path entrance, where the hardy ferns and their allies may be found, including species from all parts of the north tepmerate zone. Among these may be mentioned the ostrich fern, the cinnamon fern, Clayton's fern, the royal fern and the American royal fern, the brake or bracken, and a number of species of the shield-ferns and of the spleenworts. A collection of forms of the lady-fern, representing many variations, may be found here also. Some of the aquatic representatives of the ferns and their allies may be found in the pond nearby.

In this pond may also be found the following aquatic endog- 
enous families: the cat-tail family, the bur-reed family, the pond-weed family, the arrow-grass family, and the tape-grass family. At the junction of the brook with this pond is the water-plantain family, including, besides the water-plantain, several species of arrow-head (Sagittaria). A little beyond, in the brook, may be found the water-poppy family, represented by the water-poppy, a showy plant common in tropical regions.

Following to the north comes the large group of the grasses and grass-like plants, those whose flowers, mostly very small, are subtended by chaffy scales or glumes. This is represented by the grasses and the sedges, several beds being devoted to each of these familis. Some of the more familiar grasses are: timothy, Kentucky blue-grass, reed canarygrass, orchard grass, red-top and tall fescue-grass, all used in making hay. Other grasses of interest are: sweet vernalgrass, exhaling a pleasant odor when bruised; the Japanese plume-grass, in several forms, very ornamental; the ribbongrass, a variegated form of the reed canary-grass, and also ornamental; and species of many other genera.

The sedges are represented mainly by the large genus Carex, perhaps the most striking of which is Fraser's sedge, from the southeastern United States, at one time one of the rarest of plants, but rediscovered in recent years in large quantities in the mountains of North Carolina. The tussock sedge, common in our swamps in early spring, the cat-tail sedge, Gray's sedge and the fox sedge, are others belonging to this genus. There are also representatives of bullrushes and other sedges.

Following the sedges is the arum family, having as representative plants, familiar to many, the skunk cabbage, the green arrow-arum, the green dragon, the jack-in-the-pulpit, and the sweet flag. In the brook opposite to this family may be found the somewhat related duckweed family; the duckweeds (Lemna) are very common, these tiny plants sometimes occurring in such numbers as to cover the surface of ponds and slowly moving streams. Along the edge of the brook 
just beyond is the yellow-eyed grass family, and near it the pipewort family. Coming now to the spiderwort family, we have represented mainly the spiderworts and day-flowers. In a small pool and along its eastern edge is placed the pickerel-weed family. Here may be found a large clump of the pickerel-weed (Pontederia) which is so common in swamps and along streams in the vicinity of New York; here may also be found the water-hyacinth, which has become such a pest in some of the rivers of Florida and the West Indies, and the closely related blue water-hyacinth, of more straggling habit, also of tropical origin.

The rush family occurs next in the sequence, represented, among others, by such familiar plants as the common bogrush, the slender rush, and the common wood-rush. Following this come the members of the bunch-flower family, with several species of bellworts, the turkey-beard, the Japanese toad-lily, the fly poison, the swamp pink and others. Closely related to this is the lily family. One of the beds given over to this family is devoted to the true lilies (Lilium) in several forms; another is set aside for the onions and their relatives, of which there are many interesting forms, some of them of decorative value; while another bed is given to a miscellaneous collection of plants belonging to this family, among which may be mentioned the day or plantain lilies, the yellow day lilies and the lemon lilies, the true asphodel or king's sword, the grape-hyacinth and Adam's needle. Other close relatives of the lilies belong to the lily-of-the-valley family; here may be found many familiar plants, among them being the lily-of-the-valley (Convallaria), the wild spikenard, the common asparagus, of such wide use as a vegetable in the early part of the summer, and several species of the Solomon's-seal, both from the Old World and the New.

The amaryllis family is shown by a number of species of daffodils and narcissus. In the iris family, which comes next, many species are represented. Most familiar among these are: the common blue flag of our swamps, the yellow flag of Europe, the German iris, the Siberian iris, the Japanese 
iris and the blackberry lily. For the canna family reference is made to the plantations at the Garden fountain at the approach to the museum building and to the conservatories, and for orchids to the conservatories.

Crossing the brook now by the path paralleling the driveway, we come to the beginning of the sequence of the large series of plants with net-veined leaves and with two seedleaves (dicotyledons). This series begins with the lizard'stail family, represented here in the brook by the lizard's-tail (Saururus), a common plant of our brooks and river borders in the eastern United States. To the nettle family one bed is at present given, located near the group of magnolia trees, where may be found, among other kinds: the slender nettle, of North America; the stinging nettle, native in Europe and Asia, but introduced into this country; and the wood nettle, also a North American plant; all of these secrete an oil through the hairs covering the stem and leaves, this oil being irritating to the skin, especially in the stinging nettle. In the immediate neighborhood and to the right is the birthwort family, represented by several species of wild ginger ( $A s a$ rum), among them the common one of this region, the shortlobed wild ginger, the root of which is of medicinal value; another is Shuttleworth's wild ginger, of the southeastern United States. To the buckwheat family there are at present devoted three beds, forming a group to the left of the nettle family. The docks (Rumex) are shown in many forms, as are the knotweeds (Polygonum); the most showy of these are the Japanese and Sakhalin knotweeds, the latter a plant of considerable economic importance, being used as a fodder plant, and is a native of the Sakhalin Island; to this family also belong rhubarb, or pie-plant, and buckwheat. Next to this and near the brook is the goosefoot family, with several species, one of which, the lamb's-quarters (Chenopodium), is native of Europe and Asia, but found as a common weed in waste places and along roadsides in this country; its young shoots are sometimes used as a vegetable. Closely related to this, and just south of it, is the amaranth family, 
represented by several species of the pigweed, many of them among the commonest weeds of our roadsides and waste places. Forming a series to the right of this are: the fouro'clock, pokeweed, carpetweed and purslane families. In the four-o'clock family may be found the common four-o'clock of our gardens, a native of tropical America, its flowers opening only on cloudy days or late in the afternoon on clear days, whence its name; and the umbrellaworts, from North America. The pokeweed family is represented by the common poke or garget (Phytolacca), native of the eastern part of North America, a plant of medicinal value and poisonous, but its young shoots when first appearing above the ground are sometimes used as "greens." In the carpetweed family are the carpetweed, from which the family derives its name, a native of the United States and Mexico, but a common weed in this vicinity; and representatives of the south African figmarigolds (Mesembryanthemum), many of them very showy; they are not hardy in this latitude and must be planted out every spring. In the purslane family, among others, may be found the sunplant or common portulaca of the gardens, a native of South America; the small-flowered talinum, from the central United States; and the common purslane or pusly, a pernicious weed in many sections of the country, and often used for "greens" or as a salad.

The pink family follows, with three beds. Many kinds of pinks, catchflies, chickweeds and gypsophils may be found here. In the first pool, formed by the widening of the brook, is the water-lily family; the large yellow pond lily or spatterdock, a native of eastern North America, may be found here, as may also its relative, the red-disked pond lily, from northeastern North America; the small white water-lily, a native of northwestern North America and Asia, the European waterlily, from Europe and Siberia, and the sweet-scented waterlily, and its variety, the pink, or Cape Cod, water-lily, also find a place here; the water-shield or water-target is also a member of this family and a native of North America. The tanks in the court of the public conservatories contain a great 
many additional kinds. The hornwort family likewise occupies a position in this pool. The aquatic members of the crowfoot family are grown here, the terrestrial forms being placed in four beds to the westward; one of these beds is given up entirely to the peonies (Paeonia), of which there are a number of interesting and handsome forms, and in the other beds may be found larkspurs, columbines, buttercups, meadowrues, anemones, liver-leaf, and many other relatives; aconite, or monk's-hood, of great medicinal value, also belongs to this family.

The barberry family, which is represented by a single bed on the ridge to the right of the crowfoot family, contains, among others, the blue cohosh and the may-apple or mandrake (Podophyllum), natives of North America; the twinleaf, a native of the northeastern United States; and the Japanese plants, the two-leaved aceranthes and the red epimedium. In the poppy family may be found the oriental poppy, a native of Asia Minor and Persia, and here may be seen also the cordate bocconia, from Japan, and the Mexican poppy, a native of Mexico and found as a weed in many tropical and warm temperate regions. In the fumitory family are the bleeding-hearts (Bicuculla), represented by the wild bleeding-heart from the eastern United States. The mustard family, which comes next in the sequence, occupies two beds. To this family belong the candy-tufts, represented here by the evergreen candy-tuft, from southern Europe and Asia Minor, and the alpine rock-cress, from Europe and North America, one of the showiest flowers in early spring, its mantle of pure white flowers making it a conspicuous object; there are many other species represented in this group. The caper family has as representatives the showy pedicellaria, a native of the Old World, and the clammy weed (Polanisia), from northern North America. The white and yellow cutleaved mignonettes (Reseda) represent the mignonette family. Across the path to the right, on the ridge and partly surrounding a rocky knoll, is the bed devoted to the orpine or stonecrop family, where there may be found many of the 


\section{$(53)$}

stonecrops (Sedum), among the more showy and attractive being: the great purple stonecrop, the great stonecrop, the white stonecrop, and the mossy stonecrop, all natives of Europe and northern Asia; the wild stonecrop and Nevius' stonecrop, both from our own country; the Siberian stonecrop and the poplar-leaved stonecrop, both from Siberia; and a Japanese species, Siebold's stonecrop; also belonging to this family are the houseleeks (Sempervivum), of which there are many representatives, all from the Old World, however, as these plants are not indigenous to the New World. Many other species of this family, not hardy in this latitude, may be found in the conservatories. Across the path from the orpine family may be found the three beds devoted to the saxifrage family. The heart-leaved saxifrage, with its large, thick leaves, from Siberia, is one of the showiest plants here, sending up its large masses of pink flowers early in the spring, so early sometimes that they are nipped by the frost. Among other plants here may be mentioned: the alum-root, from the eastern United States; the two-leaved bishop's-cap, from the northern United States; the Japanese plant, Rodgersia; and the shield-leaf saxifrage, from the western United States. Menzies' saxifrage, from western North America, is interesting from the fact that in late summer and fall it produces small plants at the base of the leaf-blades.

To the herbaceous members of the rose family are allotted five beds, located to the left of the saxifrage family. Many species of cinquefoils and agrimonies may be found here; of the strawberry (Fragaria) there are several species represented; the lady's-mantle, from north temperate regions, the various species of avens, the goat's-beard, the burnets and many others, are of decorative value or of interest for other reasons. The roses, blackberries and raspberries, also members of this family, are shrubs, and may be found at the fruticetum. The mimosa family has relatively but few representatives in temperate regions, most of its numerous members being confined to warm temperate regions and to the tropics; many of these may be found in the conservatories. 
To the senna family belong the sennas or cassias, a showy representative being the American senna, a native of North America; this family being also largely of warm temperate and tropical distribution, many other species may be found in the conservatories. To the right of the mimosa family may be found the bed devoted to the pea family; to this some of our most valued economic plants belong, such as the pea, the bean and the clover; to the pea family belong also the baptisias, the bush-clovers, the vetches, the tick-trefoils and many other familiar plants.

Next in the order of sequence is the geranium family, to which belong the geraniums or crane's-bills; the plants so often cultivated in the house under the name of geraniums, but which are not hardy out of doors in our climate, are really not what they are called, but are truly pelargoniums, a closelyrelated group of plants belonging to the same family; besides our common wild geranium or crane's-bill may be found, among other plants here. A little farther on, near the brook, may be found the bed devoted to the wood-sorrel family, of ten called sour-grass by children; several species are shown here. Just to the left of the geranium family is the flax family, to which belongs the flax plant (Linum), from the fiber contained in the stem of which linen is made. Beyond this is the bed for the rue family; to this belong the common rue, of southern Europe, and the fraxinella; this family also includes the oranges and lemons, specimens of which may be found in the conservatories, and a very great number of tropical trees and shrubs. To the right of this is a small bed devoted to the milkwort family. The spurge family is in a bed just to the left of the flax family; the flowering spurge, from the eastern United States, and the cypress spurge, from Europe, but sometimes found wild in this country as an escaped plant, are both here. Along the edge of the brook, and opposite the spurge family, may be seen the water-starwort family, to which belong a number of small aquatic plants. About opposite this, and at the base of the rocky ridge to the right, are two representatives of the box family, in the trailing pachy- 


\section{$(55)$}

sandra, from North America, and its Japanese relative, the terminal pachysandra; the true box (Buxus) is a shrub or small tree, native of Europe, and several specimens of it may be found at the fruticetum. A little to the right of the woodsorrel family is the jewel-weed family, to which belong the common balsam of the gardens, and the plant so common along our brooks and other wet places, and known as jewelweed, or touch-me-not. A little beyond this are three beds of the mallow family; the hollyhocks belong here, as do the mallows; the crimson-eye mallow and the swamp-rose mallow, both from North America, are showy representatives of this family; and the marsh mallow, a native of Europe and the Orient, is also shown; its root is used in the manufacture of a mucilage and for medicinal purposes.

To the right of the mallows is the bed given over to the St. John's-wort family. The rock-rose family comes next, a little further on; here belong the rock-roses of Europe and our own frost-weeds. To the right of this is the violet family; a large collection of our native species, together with some from foreign lands, is here brought together and many of these may be recognized as old friends. $\mathrm{Up}$ on the ridge to the right, across the walk, may be found the cactus family; relatively few of these are hardy in this climate, so the larger part of the cactus collection must be sought in the conservatories. Here may be found, however, several representatives of the prickly pears (Opuntia), including the eastern prickly pear, common in this part of the country, which is frequently found on the rocky ridges in the vicinity of New York and occurs wild on some ledges within the Garden reservation. Down near the brook, and not far from the mallow family, is the loosestrife family, represented by the purple loosestrife, a native of Europe, but introduced in many places in this country; among others belonging to this family is the swamp loosestrife, or willow-herb (Decodon), a plant of which may be found along the brook opposite to the loosestrife bed. Near this, on the edge of the brook, is located the meadow beauty, one of the prettiest little flowers of our meadows. It 
belongs to the meadow-beauty family, few species of which occur in cool regions; it is largely represented in warm temperate and tropical regions, and many other species may be found in the conservatories. But a short distance from the violet family is the evening-primrose family; here may be found a number of the evening primroses (Oenothera), with their showy yellow flowers, noteworthy as the plants mainly experimented with by Professors DeVries and MacDougal in their studies on the origin of species. Along the brook, not far from the loosestrife family, is the water-milfoil family, represented by the Chilean water-milfoil or parrot's-feather, forming a beautiful mass of feathery green on the surface of the water. Returning now to the ridge, a little beyond the violet family, we find the bed allotted to the ginseng family; here are the Indian-root, from eastern North America, and the heart-leaved aralia from Japan. To this family also belongs the ginseng plant, the root of which is so much prized by the Chinese as a medicine. Down the slope from this group may be found two beds given over to the carrot family, which includes many economic plants, such as the carrot, parsnip, celery and caraway; lovage, a common European plant, is shown, and the rattlesnake-master, from the eastern United States; the wild carrot and the golden meadow parsnip also belong here.

To the primrose family, located at the base of the ridge a little beyond the carrot family, belong the primroses (Primula), many of which are natives of Europe; here we find the common European primrose, the cowslip and others; the moneywort, a native of Europe, but introduced into many places in this country, sends it long creeping stem all over the bed-this is sometimes known as creeping Charlie; the fringed loosestrife, from North America, is also here, as is the clethralike loosestrife, from Japan, with its racemes of white flowers. Between the two beds devoted to the carrot family, and a little beyond, is the plumbago family, to which belongs the common thrift of Europe; there are several other thrifts here also, as well as the statices or sea-lavenders, in several 
species. The bed allotted to the gentian family may be found a little beyond the plumbago family; various gentians are represented, among them the blind gentian, a native of the United States, and the Thibet gentian, from the Himalayas and China. In the brook, just beyond the little stone bridge, may be found the buckbean family; here are shown the water-snowflake, common in tropical regions, and the water-lily floating heart, native in Europe and northern Asia.

Just beyond the left hand bed devoted to the carrot family is the dogbane family; the willow-leaved amsonia, from the central and southeastern United States, and the broad-leaved amsonia, from the central and eastern United States, are conspicuous objects here. Beyond this are two beds of the milkweed family and among its representatives are the common milkweed of our roadsides, the hairy milkweed and the swamp milkweed; the swallowworts also belong here and are illustrated by several species. In the morning-glory family, located to the right of the above, are the small bindweed, of northern Europe and Asia, sometimes a troublesome weed in this country, and the bush morning-glory from the western United States. Following the milkweeds is the phlox family; interesting plants here are the Jacob's-ladder (Polemonium), of Europe, with its masses of blue flowers; the hairy phlox, of North America; Britton's phlox, a relative of the common ground phlox, from the southeastern United States; the ground phlox and its white-flowered form, both natives of the eastern United States; and forms of the garden phlox, also from the southeastern United States. In the shade, the natural habitat of many of these plants, is the water-leaf family, at the base of a large rock on the ridge; there are the purple, the broad-leaved and the Virginia water-leaf (Hydrophyllum).

Further along and at the base of the ridge is the borage family; the tuberous comfrey, the rough comfrey and the common comfrey, all natives of Europe, are represented. In the vervain family, in a small bed to the left, may be found: 
the wedge-leaved fog-fruit (Lippia), from the western United States and Mexico and the vervains. We now come in the sequence to the mint family, to which are devoted six beds; among the true mints may be found here the creeping whorled mint, the curled mint and the spearmint, all from the Old World. Many familiar plants may be seen in these beds, and among them are: the false dragon-head, of the United States; motherwort, common in Europe and widely distributed as a weed in this country along roadsides and in waste places; the horse-balm, of North America, common in the east in woods; Oswego tea, and other bergamots, natives of North America; the betony and hyssop, of Europe; the hedge-nettles, from both the Old World and the New; the common sage of the Mediterranean region, highly prized by the housewife, and other sages; catnip, a native of Europe, but widely distributed as a weed in this country; Gill-overthe-ground, or ground ivy, also a European plant, but extensively spread as a weed in this country; and the dittany, of North America.

The potato family may be found a little to the left and just beyond the phlox family. Here may be seen the common jimson, or Jamestown, weed, the seeds of which are poisonous, a native of tropical regions, but a common weed along our roadsides; the nightshade, a European plant, but commonly distributed as an introduction in many parts of this country, also with poisonous fruit; tobacco plants and solanums; it is to this family that the potato, tomato and eggplant belong. A little beyond and to the left of the mints are the two beds allotted to the figwort family; of interest here are: the beard-tongues, of which there are several species; the speedwells (Veronica), among them the long-leaved speedwell and the gentian speedwell; the fox-gloves (Digitalis), from one of which, the purple fox-glove, the valuable medicine digitalin is derived; Lyon's snake-head from the southern states; culver's-root, from the southeastern United States; and several figworts. Just beyond this may be found the unicorn-plant family, represented by the unicorn-plant. 
A little beyond is the globularia family, represented by a single species of globularia. To the right is the acanthus family; not many of these plants are hardy in this latitude, but in the conservatories many representatives may be found, as the family is largely confined to tropical and warm temperate areas; in this bed may be seen the hairy ruellia, from the southeastern United States. In this neighborhood may also be seen the lopseed family, represented by the lopseed, a native of eastern North America.

To the right of the acanthus family is the single bed devoted to the plantain family; several species, such as $\mathrm{Ru}$ gel's plantain and rib-grass, are pernicious weeds in this neighborhood, often disfiguring an otherwise even lawn. Just beyond the mints may be found the two beds of the madder family; to this belongs the dainty little bluets or innocence, which sometimes give a blue sheen to sterile, sandy places, so abundant is it in some localities; it is quite common in eastern North America; several species of bedstraw ( $\mathrm{Gal}$ ium) may also be found here, while many other plants belonging to this family are grown at the conservatories, among them the coffee tree. A little beyond is the single bed of the honeysuckle family, represented by the feverworts; this family being large composed of woody plants, many other species, including the true honeysuckles, may be found in the fruticetum and in the viticetum. To the left is the valerian family with a single bed; here may be found the valerian, a common European plant.

Just beyond the plantain family is the teasel family. It is to this that the teasel plant belongs, used in olden times for raising the nap on woolen cloth. Several species of cephalaria may be found here. The bell-flower family is a little further on and to the left; the Carpathian and Host's bellflowers, both natives of Europe, are pretty representatives here; the creeping bell-flower, or Canterbury bells, also a native of Europe, may be found here in several forms; the Japanese bell-flower and its white variety are also here, their large showy flowers making them quite conspicuous. A little 
further on and to the left is the lobelia family; the cardinal flower and the blue cardinal flower, both natives of North America, make showy objects; the former is particularly striking in its rich masses of cardinal-red flowers.

To the right of the teasel family is the chicory family. The common lettuce (Lactuca), so much used in salads, belongs here; many of the plants are extremely weedy by nature, and this is particularly true of the hawkweeds, a genus richly represented in the Old World, several species of which are shown here; the oyster plant is also a member of this family.

To the left of this may be found the ragweed family. All the species here are of a weedy nature. The ragweed, the giant ragweed and the common clot-blur find representation here. Terminating the sequence comes the very large thistle family, represented by many species from all parts of the world; there are nine beds at present given over to these plants; the sunflowers, coneflowers, thistles, asters, fleabanes, yarrows, golden-rods, tansies, sneezeweeds, burdocks, artemisias and wormwoods, cat's-foot, tick-seeds, elecampane, boneset, chrysanthemums, colt's-foot and many others are shown; the Jerusalem artichoke, one of the sun-flowers, a native of eastern North America, bears edible tubers.

\section{(b) Morphological Garden}

This is located to the north of the systematic collection, the two collections being separated by the driveway which crosses the valley. It is designed to illustrate here with typical examples the organs and other features of plants, including leaf-forms and the various modifications of their margins, their venation and insertion on the stem; also the various kinds of stems, methods of propagation, flower-clusters and fruits, leaf-movements, parasites, desert plants and seed-dispersal. Looking north on this collection, the first bed to the right of the brook contains plants illustrating simple leafforms. Immediately following this on the same side of the brook are the plants representing the various forms of com- 
pound leaves, or those in which there is a distinct jointing of the leaflets to the leaf-axis. Farther along the brook, in the pool, may be found various forms of aquatic roots, stems and leaves; and a little beyond this to the right is the bed containing plants illustrating forms of propagation.

The remaining plots of this collection are located on the left hand or westerly side of the brook. The first of these to the right is devoted to leaf-venation, and the one to the left to leaf-margins, the former illustrating the character of the veins and nerves, and the latter the toothing or lobing of the margins. Beyond this to the right is the group of plants showing the manner of insertion of the leaves on the stem; and to the left of this are specimens illustrating the various ways in which plants may form a mosaic covering on the ground. A little beyond are the examples of stem-forms. One bed is devoted to show the smaller kinds, while for the larger examples, illustrating tree, twining, root-climbing and tendril-climbing stems, specimens have been selected or placed to the left of this bed and properly labeled.

A little beyond the pool may be found the bed illustrating flower-clusters, and still further on that devoted to parasitic plants, or those deriving their nourishment from the living tissues of other plants. To the left of this and farther up the hill is the group of plants showing leaf-positions. Beyond and a little to the right are plants which are at home in desert regions, and the various means of accommodating themselves to their natural surroundings are shown. Further on to the right is the bed devoted to fruit-forms; and to the left of this, one showing various forms of seed-dispersal; those with the surface of the fruits covered with some sticky substance or curved appendages or hooked hairs or spines require the intervention of some animal for their distribution, while those with wings or with hairs attached to the seed are spread through the agency of the wind. To the right of the above are plants representing a species and a variety, and to the left of this is a bed containing plants showing species and hybrids. 


\section{(c) ECONOMIC GARDEN}

The collections illustrating food plants and those producing substances directly useful to man in the arts, sciences and industries are being installed at the northern end of the long glade containing the herbaceous collections just described.

On the east side of the broad central grass path and the brook are located plants used for medicine, those employed as condiments or relishes and a number of plants from which the fiber is used in the manufacture of various fabrics. The bed containing the plants used for condiments or relishes is at the extreme north end of the collection, while that devoted to the fiber plants is at the southern end. The remaining beds are given over to medicinal plants. The medicinal plants which grow in wet or moist situations may be found on the easterly side of the brook. Along the woodland border is also a collection of medicinal shrubs and trees.

On the west side of the grass path and brook are the food plants. Here may be found many of the common fruits and vegetables. A general sign is placed in each of the beds denoting what its contents are intended to represent, and in front of each plant is a smaller label giving individual information. Along the stone path is a collection of shrubs and trees, containing some of the more common plants producing edible nuts and fruits.

\section{(d) Viticetum}

The area devoted to the plantation of vines is at the easterly side of the economic garden. Hardy vines, whether woody or herbaceous, belong here, and a rough arbor has been constructed for them to climb on. This collection is now being developed, and only a few of the species which it is intended eventually to grow there are as yet in place. The families will be referred to below in the order of their sequence. The arrangement begins at the southerly end of the arbor, on the left hand side, with the smilax family, to which belong the green-briers or cat-briers. The yam family is placed immediately opposite to the right, followed by the 



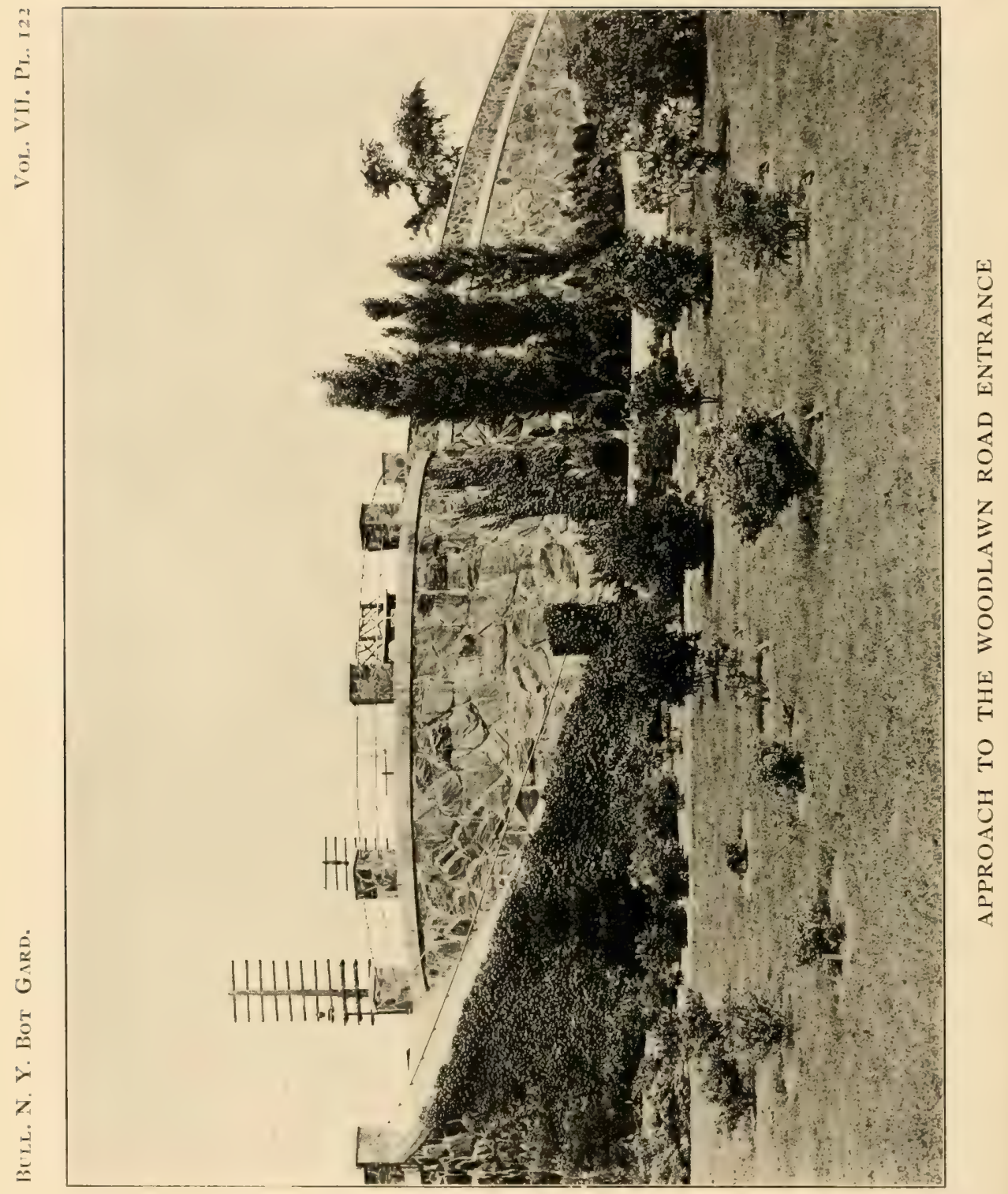


mulberry family on the same side. The birthwort family, with the dutchman's-pipe as a representative, follows the smilax family on the left, and opposite to this is placed the buckwheat family, to which belong the climbing bindweeds and brunnichia. On the left hand side, and beyond the birthwort family, is the akebia family, where one may find the five-leaved akebia, a native of Japan. Following this on the same side is the moonseed family, to which belongs the Canada moonseed. On the opposite side of the arbor is the hydrangea family. The next family, occupying both sides of the arbor, is the rose family, where may be found some climbing roses. Following this, also on both sides of the arbor, is the pea family, where one must seek the peas and wistarias. Further on, occupying both sides, is the staff-tree family, where may be found the climbing bitter-sweet and other vines of this family. Succeeding this comes the grape family, to which belong the grapes, the Virginia creeper and the Japanese ivy. On the right, beyond the grape family, is the actinidia family, represented by the toothed actinidia. Opposite to this is the morning-glory family, where the morningglories and moon-flower belong. Then comes the trumpetcreeper family, of which the trumpet-creeper, a native of the southeastern United States, is a member. This family in turn is followed by the honeysuckle family, represented here by several species of honeysuckle and woodbine. The sequence terminates with the gourd family, to which belong, as economic plants, the watermelon, cucumber, squash, muskmelon and gourds; a common vine of eastern North America, and frequent in the valley of the Bronx, is the one-seeded bur-cucumber, or star-cucumber, also a member of this family.

\section{The Fruticetum}

\section{[COLLECTION OF SHRUBS]}

This plantation, occupying about I 6 acres, is located to the northward of the lakes in the rear of the museum building, 
and is confined to the area lying between the lakes, the railroad, the woodland on the east, and the north meadow. In this collection are brought together all the hardy woody plants which are shrubs, that is, plants with woody stems which branch from the ground and have no single main stem. The arrangement here parallels that in the herbaceous grounds and in the other systematic collections. The sequence begins on the southerly side near the large stone bridge which crosses the Bronx River, and proceeds on both sides of the path running to the north along the edge of the woods, returning southward on both sides of the path paralleling the main north and south driveway, to the plum family, on the bank overlooking the easterly lake. It then crosses to the senna family directly opposite and overlooking the westerly lake, proceeding northward from there across the transverse driveway, and following the line of the path paralleling to the westward the main north and south driveway. The sequence then continues to the westward along the north path, again extending southward at the Woodlawn Road entrance, continuing on both sides of the westerly path and terminating with the thistle family at the westerly end of the lake near the railroad border. The families will be referred to below in this sequence.

The pine family, represented by some of the low-growing junipers and pines, begins the sequence to the southward of the approach to the long bridge. The next is the willow family, beginning across the road from the pine family; this group is located on both sides of the path and comprises many forms from various parts of the world; the family is largely an inhabitant of temperate regions, so many species can be grown here. The bayberry family occurs across the driveway from the willows, occupying a position on the bank overlooking the easterly lake. Here may be found the sweet-fern, a native of eastern North America; the sweet gale, at home in north temperate regions; and the waxberry or bayberry, common in eastern North America; the berries of the latter have a covering of wax, 
which was separated by throwing the berries into hot water, when the wax melted and rose to the surface, where it was skimmed off; it is still used to some extent in making candles. The birch family follows the willows on the east side of the path; here are the hazel-nuts, the alders and the shrubby birches; the common hazel-nut and the beaked hazel-nut, both from North America, also the common hazel-nut or filbert of Europe, and others; the smooth alder, common along streams and in swamps, is also here. Following the birch family on the same side of the path comes the beech family; here may be found the shrubby oaks and the chinquapin of the southeastern United States. On the same side of the path, a little farther along, is the elm family, represented by the dwarf elms; most of the members of this family are trees and may therefore be found in the arboretum. Immediately following this is the mulberry family, represented here by two specimens of the Tartarian mulberry. At the triangle a little further on is the cercis-leaf family, represented by the cercis-leaf (Cercidiphyllum), a Japanese tree, and known to the people there as katzoura; there are three specimens of this, most attractive in the spring with their tender greens flushed with rose.

The crowfoot family occupies a space just to the north of the willows west of the path, and is represented by the moutan or tree peony, from China, and the shrub yellow-root (Xanthorrhiza), from the eastern United States; its roots are yellow, and at one time were employed as a dye; there are many herbaceous members of this family at the herbaceous grounds. The barberry family is a little farther north on the same side of the path; many species of barberries and mahonias occur here. Among the barberries may be mentioned: the common European barberry, the ripe fruit of which is sometimes made into preserves, and the unripe ones pickled as a substitute for capers-its bark is used as a dye and for tanning leather; Thunberg's barberry, from Japan, a desirable plant for small hedges and for the borders of walks; the neat barberry, from the Himalayan region, which 
colors a beautiful red in the fall; and the large-toothed barberry, from Nepal; the mahonias are represented by the erect Oregon grape, from northwestern North America; and the Japanese mahonia. The magnolia family occurs a little back from the path, between the crowfoot and barberry families; there are here several species of shrubby magnolias. The strawberry-shrub family follows the barberries, immediately across the path from the cercis-leaf family; here may be found several species of the strawberry-shrub, including the hairy one which has the fragrant flowers scented like the strawberry; the fragrant Chimonanthus, from Japan, is a member of this family, and is known to the natives there as karamume. A short distance to the eastward of the cercisleaf family is the laurel family, represented by the spice-bush (Benzoin), a native of northeastern North America; as the different kinds of flowers, staminate and pistillate, are borne on different plants, only those having pistillate flowers bear the bright red berries in the summer and autumn. To the west of this is the Virginia willow family, with shrubs of the Virginia willow, a native of the southeastern United States. To the north of this is the hydrangea family; here may be found the syringas, the deutzias and the hydrangeas, several species of each; the mock orange (Philadelphus), a native of Europe, indicates its presence by the rich fragrance of its flowers; the slender deutzia, from Japan, bears its long slender clusters of white flowers in great profusion; the large-flowered hydrangea, a Japanese plant, bears a profusion of large bunches of white flowers, which in the late summer and autumn change to a beautiful rose color; the oak-leaved hydrangea is perhaps the oddest member of this genus; it is native from Georgia and Florida to Mississippi. Following the hydrangea family comes the gooseberry family, and to this belong the currants and gooseberries; one of the showiest is the long-flowered golden currant, from western North America; its rich yellow flowers give forth a delicious spicy fragrance. The witch-hazel family is located to the north of the north path; here is the common witch-hazel, of eastern 
North America, from which the extract of witch-hazel, or Pond's extract, is made; the spiked corylopsis, a Japanese shrub, belongs here, as do the fothergillas of the southeastern United States.

The rose family occupies a large area, beginning just north of the gooseberries and currants and extending westward to the main north and south driveway, and southward along that as far as the first transverse path; here belong the spiraeas, of which there are many forms, the blackberries, the raspberries, the roses and others. Among the spiraeas, the steeple-bush or hard-hack and the willow-leaved meadowsweet, or quaker-lady, are common as wild plants in this latitude. Other interesting forms are Thunberg's spiraea, from Japan, and other Japanese spiraeas. Among other plants of interest in the group which contains the spiraeas are the large-flowered exochorda, a native of northern China, with its profusion of white flowers in early summer; the Japanese rose, from Japan, not a true rose, however, with bright yellow flowers; another shrub from Japan, known to the natives of that country as siro yama buki, bears large white flowers resembling in appearance those of the mock orange; two other Japanese shrubs, members of the same genus, and known to the natives there as kago ma utsugi and yama doosin, respectively, the former an exceptionally graceful and attractive plant; Neviusia, an extremely local plant, known in a wild state only in Alabama; and the nine-bark, of eastern North America. To the southward of the spiraea group comes the collection of blackberries and raspberries (Rubus) represented by many kinds; two of the showiest are the Japanese wineberry and the purple flowering-raspberry, the latter common in rocky woods in this part of the country. Farther to the south, and bordering both sides of the transverse path, is the group of the true roses; many kinds may be found here, including the sweet-brier, the dog-rose, or wild brier, and the red-leaved rose, all natives of Europe; the low or pasture rose of eastern North America ; and the odd-looking Watson's 
rose, a native of Japan. Numerous herbaceous species of the rose family are grown at the herbaceous grounds.

Following this is the apple family; to this belong the apples and pears, many of which, being trees, may be found in the arboretum. Of a shrubby habit, and therefore members of this collection, are many of the hawthorns or thorn-apples, the quinces, the rose-boxes, the choke-berries, the serviceberry and the shad-bush. Southward across the driveway from these, and overlooking the easterly lake, is the collection illustrating the plum family, to which belong the plums, cherries, apricots and peaches. As many of the species of this family are trees they may be found at the arboretum. Among those represented here are the western sand cherry, of northwestern North America; the three-lobed peach, a native of China, with its double-flowered form; the dwarf peach, from Europe; and the Russian almond, of Russia and western Asia.

Crossing the driveway to the west, the sequence is again taken up on the ground overlooking the west lake, with the senna family, represented by the Asiatic Judas-tree, of China and Japan, and the American Judas-tree of the eastern United States; in spring, before the appearance of the leaves, these are profusely covered with pink or purplish flowers. Across the transverse driveway to the north, and directly on the opposite side, may be found the pea family. Here are various species of the pea-tree: the pigmy pea-tree, from the Himalayan region; the Chamlagu pea-tree, from China; the common pea-tree and the small-leaved pea-tree, both from Siberia. In the fall the two-colored bush-clover, from China, is a show of purple bloom. The white broom, the common broom and the dense-flowered broom, all of Europe, have representatives here; of these, the common broom, in Spain and France attains the size of a small tree, and its wood is highly prized for veneering and cabinet work; its branches are extensively employed for making brooms, whence its common name. Other plants of interest are the false indigo and the bristly locust, both from the southeastern United States; the woody 
bladder-senna, from Europe and the Orient; and the scorpion senna, from southern Europe. Immediately beyond is the rue family, illustrated by the shrubby trefoil (Ptelea trifoliata) of the eastern United States; the prickly ash, from the northeastern United States; and the trifoliolate orange, from Japan, which has been used as one of the parents in the recent hybridization experiments by the U. S. Department of Agriculture in its effort to produce a more hardy orange; the lemon and forms of the orange may be found in the conservatories, together with other woody members of this family. The tanners'-tree family comes next with a single representative, the tanners'-tree, from the Mediterranean region. Following this is the box family, represented by a number of forms of the box-tree, from Europe, Asia and Japan; the wood of the box-tree is highly prized for wood-engraving, on account of its hardness and close fine grain, and it takes a fine polish. A few steps further on is the sumac family, to which belongs the common poison ivy, so frequent in and around New York City; here are the fragrant sumac, the mountain sumac and the smooth or scarlet sumac, all from the eastern United States; Osbeck's sumac is a stately shrub from China. The European and the American smoke-trees (Cotinus) are relatives of the sumacs; the former is sometimes called the wigtree, on account of the flower-clusters which become white and feathery in fruit; a dye is obtained from it which is called young fustic.

Crossing the transverse path to the triangle, the holly family is on the nearest point, shown by the serrate holly and the crenate holly, both from Japan; the European holly is grown in the conservatories and the American holly at the arboretum. The Virginia winter-berry, of the eastern United States, bears its bright red berries far into the winter. On the opposite corner of the triangle is the staff-tree family, illustrated by many forms of Euonymus; the European stafftree, the burning-bush of the eastern United States, the winged spindle-tree of eastern Asia and Bunge's spindle-tree of the Amur region are shown. Crossing the path to the north 
of the triangle we come to the maple family; most of the maples are trees, so they must be looked for in the arboretum, but here are specimens of the Ginnala maple, from northern China and Japan. Immediately beyond this is the bladdernut family, represented by species of the bladder-nut (Staphylea), both from the New and the Old World. Following the path to the west, we come to the buckeye family, represented here by the small-flowered buckeye, from the southeastern United States; many of the buckeyes and horsechestnuts are trees, and are grown in the arboretum. Following this is the soapberry family, with the genus Canthoceras, a native of China, as a representative. At some distance from the path to the left is the buckthorn family; the most familiar plant here is the New Jersey tea, or red root, of eastern North America; its leaves have been used as a substitute for tea, and it is said that the industry is being revived in Pennsylvania; the jujube-tree, an inhabitant of the Mediterranean region and temperate Asia, is of this family, its edible fruit oval in shape and about the size of a plum, with an acid taste when fresh; the Dahurian buckthorn, growing wild from central Asia to the Amur region, and the purging buckthorn of Europe, the berries of which are medicinal, are here; from the juice of the ripe fresh berries of the purging buckthorn, mixed with alum, is made the pigment, known as sap-green or bladder green, used by watercolor artists. The mallow family, further along the path, is represented by two specimens of the rose-of-Sharon (Hibiscus syriacus), from western Asia, and often found escaped from cultivation in the eastern United States; many herbaceous representatives of this family may be found at the herbacious grounds. Near the mallow family is the tea family, represented by the mountain Stuartia, from the southeastern United States; other members of the tea family, including the tea plant and the common camellia, may be found in the conservatories. Also near the mallows may be found the St. John's-wort shrubs (Hypericum), with their showy yellow flowers. Farther on, where the path bends to 
the left, is the tamarix family, represented by several species of tamarix, Old World plants. Next comes the mezereon family, having as a representative the leather-wood or moosewood (Dirca), of the eastern parts of North America; the name leather-wood refers to the very tough inner bark; the bark is a violent emetic.

Some distance from the path and opposite the Woodlawn Road entrance, is the oleaster family, including several species of oleaster, the buffalo berry and the sea-buckthorn, a native of Europe, the berries of which are acrid and poisonous; the berries of several of the species of oleaster are edible; the buffalo berry, of northwestern North America, is largely eaten by the Indians of that region; the berries of the oriental oleaster, known as Trebizond dates, are made into cakes by the Arabs, after having been dried. Plants of the ginseng family form a group opposite the same entrance, some of these being quite tropical in aspect; the Japanese angelica-tree, from Japan, is one of these, and another is Maximowicz's acanthopanax, also from Japan; the variegated Chinese angelica-tree, a native of China, is quite ornamental. Beyond this group, and on both sides of the transverse path, is the dogwood family, shown by many species of dogwood or cornel (Cornus), from both the Old World and the New; the red-osier dogwood, the kinnikinnik and the panicled dogwood are American representatives; the officinal dogwood comes from Japan and is known there as sandzaki; the dogberry, gater-tree, or hound's-tree, is from Europe and western Asia; its wood is hard and is sometimes made into butchers' skewers and tooth-picks; in France, an oil used for burning and in soap-making is extracted from the black berries.

Across the path from the dogrroods, at the foot of the steps, may be found the white-alder family. Here are the Japanese sweet-pepper bush and the North American sweetpepper bushes or white-alders, their fragrant white flowers appearing in August. The heath family is next, represented by many forms of azeleas and rhododendrons; the Japanese 
Pieris is a pretty plant, and another of the same genus, from the southeastern United States, is called stagger-bush. Following the path to the south, we come next to the huckleberries and to the shrubs of the storax family. On the other side of the path is the olive family, which covers a large area, extending along the path for a considerable distance; the olive-tree is the type of this family, and specimens may be found at the conservatories; in the fruticetum are several forms of the golden-bell (Forsythia), from China; a number of the privets, including the California privet, so much used for hedges; a variety of lilacs (Syringa), including the Rouen lilac, from China, the Pekin lilac, from southern China, the Himalayan lilac and the common lilac, a native of eastern Europe, so frequently cultivated in gardens, and the adelias. To the right of the path and following the storax family is the logania family, with species of Buddleia, including the showy variable buddleia, from China. Following this is the vervain family, and some of these shrubs are especially attractive in fruit, among them being the purple callicarpa, from China, and the Japanese callicarpa; most attractive is the late-flowering clerodendron, a Chinese plant, whose flowers have a delicious spicy fragrance, much like that of the sweet-pepper bush; the sepals are a beautiful rose color, while the corolla is creamy white; it blooms late in the summer or early fall, when flowers of shrubs are few.

We next come to the potato family, shown here by the matrimony vine, a native of Europe, but often found growing wild, its purple flowers followed by bright red berries; most of the hardy representatives of this family are herbs, so must be sought for in the herbaceous grounds, while many of the woody species, and some of the herbs, are tender, and may be found in the conservatories. The succeeding group is the honeysuckle family, to which is allotted a large area, there being many hardy kinds; the viburnums are represented by many species, both from the Old World and the New, such as the cranberry-tree, from north temperate regions, ornamental by its masses of bright red fruit; the dwarf cran- 



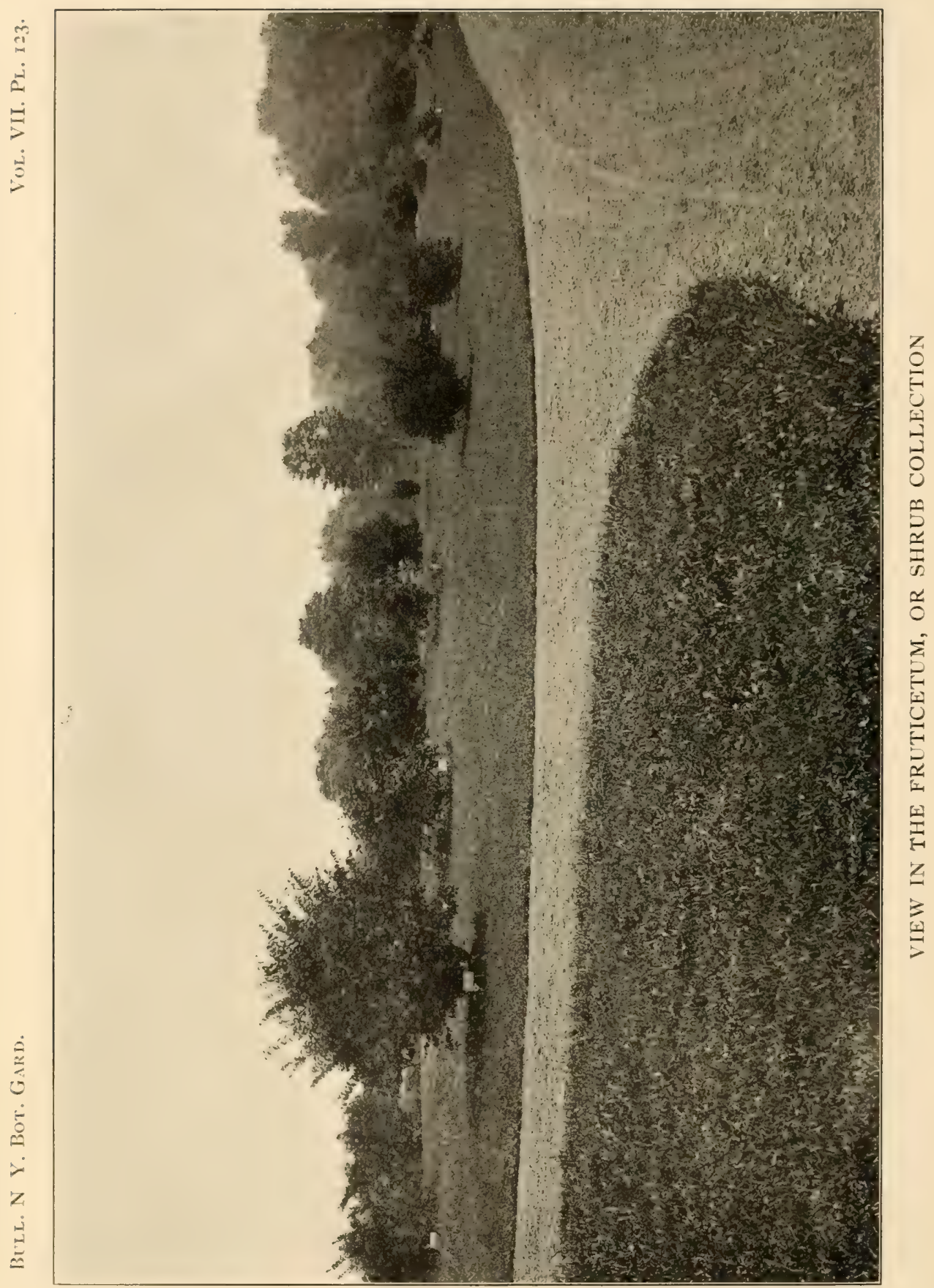


berry-tree, an exceedingly compact form, very dense in its growth; the Chinese viburnum, from China and Japan; Siebold's viburnum, from Japan; the Japanese snowball, from China and Japan; the wayfaring tree, from Europe and Asia; and the woolly viburnum, from China and Japan; among American forms may be mentioned the arrow-wood, the coast arrow-wood, the black haw or sloe, the withe-rod, and the larger withe-rod with its large bunches of showy fruit. The group of the honeysuckles occupies a position across the path from the viburnums, and here may be found, among others, the fragrant honeysuckle, from China, one of the first to send forth its blossoms richly laden with perfume; Morrow's honeysuckle, from Japan, covered with coralred fruit in late summer and fall; Standish's honeysuckle, from China; the narrow-leaved Albert honeysuckle, from Turkestan; the blue fly-honeysuckle, from north temperate regions; and the golden-veined honeysuckle, from China and Japan, with the veins richly marked with yellow, or sometimes the whole leaf yellow. Across the transverse path to the south, and overlooking the lake, may be found the weigelas, symphoricarpos and the diervillas; the weigelas are illustrated by many showy forms, flowering in early summer; the showiest Symphoricarpos is the snowberry, native of northern North America, laden in autumn with its ivory-white fruit, making it most attractive; the diervillas are represented by two or three species, including the bush honeysuckle, a native of northern North America. The elder-berries (Sambucus) are also represented by two or three species. The Chinese abelia will also be found here; its fragrant flowers are borne in great profusion during late summer and early fall; the sepals are deep red-brown and the corolla is white, flushed with rose, making a pleasing combination.

Following the viburnums comes the thistle family. Few of the woody species of this family are hardy in this latitude, but large numbers of the herbaceous species may be found at the herbaceous grounds. As representatives in the frutice- 
tum, we have the groundsel-bush or pencil-tree (Baccharis), a native of the southeastern United States, bearing in the fall a profusion of white fruit, making it a most attractive object; and some of the shrubby wormwoods (Artemisia) of the Old World.

Salicetum.-The area occupied by this plantation is between the main driveway and the Bronx River, north of the fruticetum, and comprises several acres. Here are brought together moisture-loving willows (Salix) and poplars (Populus) as a collection apart, many species grown here not being represented in the arboretum and fruticetum. Immediately beyond the uncompleted north path at the fruticetum is a row of poplars, fringing the southerly end of the north meadow, consisting of several trees each of Simon's poplar, from China, and Wobst's poplar, a Russian species. In the corner of the salicetum, next to the driveway, is a group of willows, consisting, in part, of the red-stemmed yellow willow, of horticultural origin, and the Ural purple willow. To the east of this may be found the golden, or yellow willow, of common occurrence in eastern North America, and Bashford's willow, a native of France. Along the west bank of the Bronx River may be found a row of trees of the cottonwood, or Carolina poplar, found wild in eastern North America; and another row of the weeping willow, a native of Asia. At the northern end of the area devoted to this plantation are to be found, among others, the purple willow, a native of Europe; and the black willow, of North America. Many other species are represented in this collection.

\section{The Deciduous Arboretum}

This plantation extends over most of the garden area east of the Bronx River. The sequence of plant families begins at the southeast entrance to the grounds and continues northward to the northern boundary, occupying the easterly ridge and the low grounds adjacent thereto. Here hardy trees are brought together, trees being regarded as woody plants which have a single main stem arising from the ground and not 



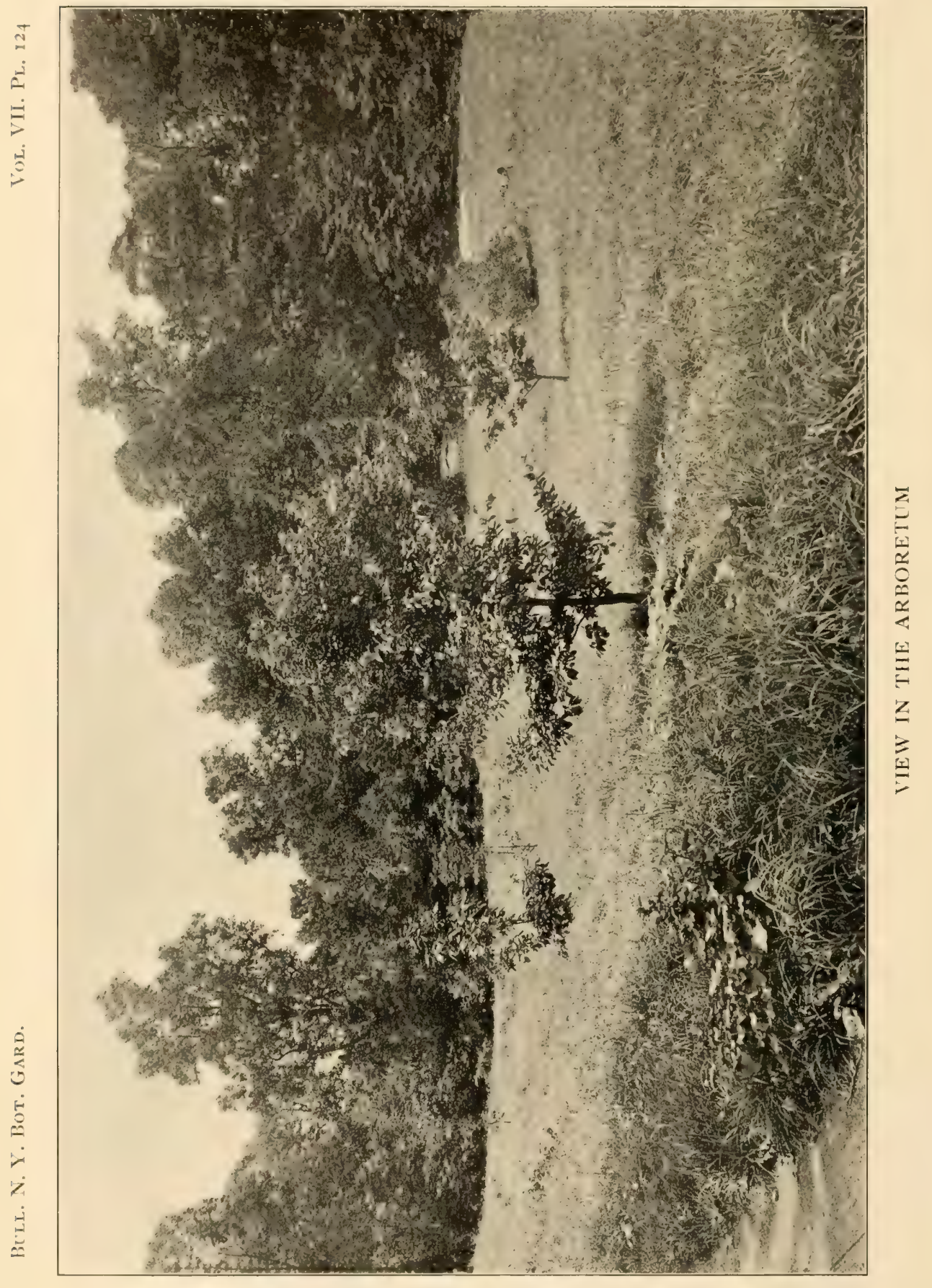


branching until some distance above it. This collection is only partially formed, but additions are made to it every season. The groups will be referred to in the order of their sequence.

The first is the willow family which occupies the low-lying land near the southeast entrance and the ridge to the north, where a collection of willows and poplars may be found. Of these Simon's poplar, from China, is of rapid growth and upright habit, and more graceful than the cottonwood or Carolina poplar; the American aspen, a native of northern North America, the wood of which is largely manufactured into pulp for the making of paper; in northern British America it is the principal fuel of the Indians, as it burns freely when green and without sparks; the inner bark, which is sweet, is often used by them as a food in early spring. This tree has been of great service in re-foresting large tracts which have been denuded by fire; the long hairy appendages to the seeds enable the wind to carry them far and wide, and as they germinate quickly and the young seedlings grow rapidly in exposed situations, it is admirably adapted to the above purpose, quickly furnishing a covering for the land until more desirable trees may get a foothold. Bolle's poplar, a form of the white, or silver-leaf poplar, is quite ornamental in its lobed leaves; the white or silver-leaf poplar is a native of Europe and Asia. Another ornamental tree and one frequently used where quick growth is desired, is the eastern cottonwood, or Carolina poplar, common in eastern North America. There also is the Lombardy, or Italian poplar, from Europe and Asia, with its tall spire-like growth. Among the willows are the golden willow, from eastern North America, and the weeping willow, native of Asia, a tree commonly planted for ornamental purposes, and sometimes known as Napoleon's willow.

The walnuts and their relatives may be found to the west of the nursery on the ridge. The narrow-winged wing-nut, from China, and the Rhoeas-leaved wing-nut from Japan, are both here. Of the walnuts (Juglans), the English wal- 
nut, native from southeastern Europe to China, produces a most desirable nut, often called Madeira nut; the Romans introduced it into Italy, and from that place as a center its cultivation has spread in all directions, both in the Old World and the New; the nuts form a common article of food in southern Europe; in Europe and northern India an oil, called walnut-oil, used as a substitute for olive-oil, is obtained by subjecting the seed-leaves to pressure. The black walnut and the butternut are both wild elsewhere in the Garden. The pecan-nut (Hicoria pecan), wild in the south central United States, is another nut of popular favor, as is also the big shagbark, or king-nut, of the eastern United States. The water hickory, of the southeastern United States, and the bitter-nut or swamp hickory, of eastern North America, are both represented, while the common shag-bark hickory and the pignut grow elsewhere in the grounds.

The birch family is located on both sides of the driveway to the south and southwest of the stable, where birches, alders and hornbeams are planted; the Japanese hornbeam is represented by a single specimen along the road to the propagating houses; the American hornbeam is common in Bronx Park, and the hop-hornbeam is occasional. Those desiring to study the birches (Betula) will find several species available; one of these is the yellow birch which grows wild in eastern North America, and is one of our most valuable timber trees; the wood, on account of its closeness of grain, strength and hardness, is suitable for many purposes. Another is the paper, or canoe, birch, of frequent occurrence in northern North America; the wood of this is preferred to that of any other tree for the manufacture of spools, and is also used in the manufacture of shoe-lasts and pegs; the Indians also make use of its wood in the manufacture of sledges, and from its tough bark they also make canoes and baskets. The Japanese white birch, a close relative of the American and European white birches, is represented. The river or red birch may be seen here; it is frequent along streams and lakes in the eastern parts of the United States; its wood is used in 
the manufacture of furniture. The black, or sweet birch, and the poplar-leaved birch are wild elsewhere in the Garden. The alders are present in several species: the dye alder, of Japan, which becomes a large tree; the Japanese alder, also of Japan; the speckled, or hoary, alder, of north temperate regions; and the European tree alder.

The area devoted to the beech family lies to the westward of that assigned to the walnut and birch families, and on both sides of the road leading to the Lorillard mansion. The oaks, the chestnuts and the beeches belong here. The oaks (Quercus) are represented by many species. One of those to the east of the road referred to above is the pinnatifid-leaved oak, from Japan, with its odd leaves cut into long linear lobes; it is said to be a form of the toothed oak of Japan. Near by is the rock chestnut oak, of eastern North America; its wood is strong and durable, especially when in contact with the soil, and is therefore of great value for railroad ties and fence posts, and its bark is largely used for tanning. The mossy-cup, or bur oak, also of eastern North America, may be found here; this was discovered by the botanist Michaux in 1795 , and is a valuable timber tree, its wood largely used for boat-building, for the manufacture of carriages and agricultural implements, for the interior finish of houses, and, on account of its durability in contact with the soil, for railroad ties. To the west of the road may be found other oaks. The red oak and the swamp white oak are natives of eastern North America; the latter is also a good timber tree, its wood being used for cabinet work and in various kinds of construction. The Japanese silkworm oak forms a part of this collection; its leaves are much like those of the chestnut, and might easily be mistaken for them; it is often planted in Japan in the silk districts, as its leaves are available as food for the silkworms, whence its name; the Japanese make charcoal from its wood, and from the bark they extract a black dye. The post, or iron oak is a native of the eastern United States. Here may be seen also the sessile-flowered English oak, a native of Europe and western 
Asia. The large-toothed oak, of Japan, a valued timber tree there, is represented near by; as is also the gland-bearing oak, another Japanese species. The shingle, or laurel oak, of the central parts of the United States, is not of much commercial value, as its wood checks badly in drying; it is sometimes used in making clapboards and shingles. Schneck's red oak comes from the south central parts of the United States. The Turkey oak, of southeastern Europe and western Asia, is valued in that region on account of its bark which is used in tanning leather. The swamp oak, the scarlet oak, the black oak and the white oak are to be seen in large wild specimens elsewhere in the grounds.

The chestnuts (Castanea) are represented by the Japanese chestnut, of China and Japan; in addition to this, in various parts of the grounds, the American chestnut may be found as wild specimens. The beeches (Fagus) are located to the westward of the chestnuts, in the north part of the swale. The European beech and its purple-leaved variety may both be found here in small, recently planted trees. Small trees of the American beech are also here, but large wild specimens may be found along the driveways and paths in the vicinity; the wood of the beech takes a high polish and is largely used for furniture, while the nuts are edible. The uses of the European beech are about the same as those of the American.

The elm family, to which belong the elms, the hackberries, or sugarberries and the water-elms, is located on the ridge to the north of the stable. Among the elms (Ulmus) to be found here is the Scotch, or Wych elm, a native of Europe and Siberia; the late-flowering elm, growing wild from Tennessee to Alabama; the cork, or rock elm, of northeastern North America; the Chinese elm, of northern China and Japan; and the winged elm, or wahoo, of the southeastern United States. The American elm and the slippery elm are wild in the grounds. The hackberries (Celtis) represented are the southern hackberry, of the southeastern United States; and the American nettle-tree, or sugar-berry, of eastern North America. The water-elms are illustrated by the pointed 


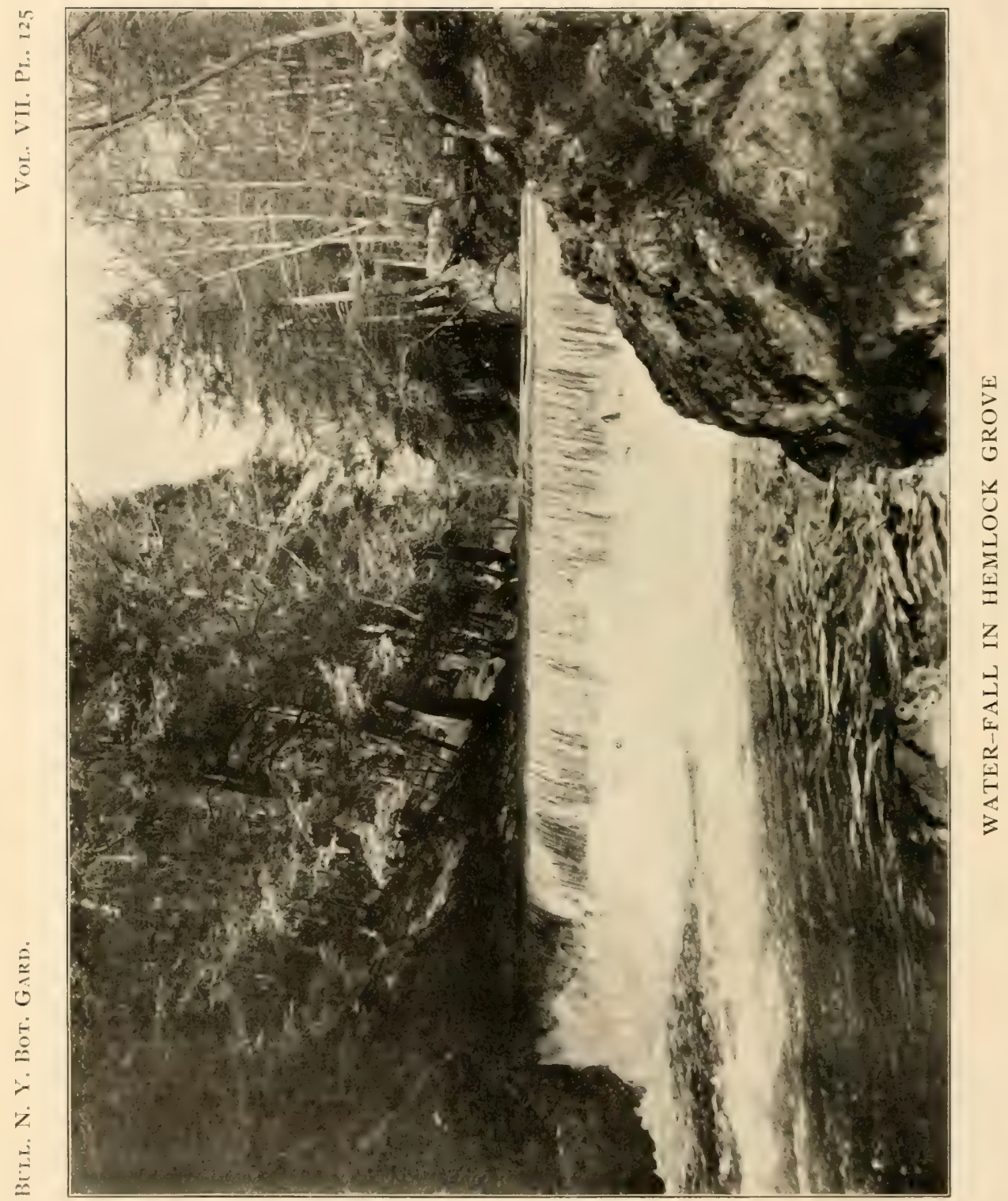


water-elm, a native of Japan. The mulberry family is represented by the osage orange (Toxylon), trees of which may be found to the south of the driveway; it is a native of the central parts of the United States; the red mulberry and the white mulberry are wild. The cercis-leaf family has for a representative the cercis-leaf, of Japan, located just to the south of the row of tulip trees just east of the Bronx River. The magnolia family is planted in the swale lying between the two ridges. Fraser's magnolia is one of those to be seen here; it is a native of the mountain woods from Virginia to Florida and Mississippi. The tulip-tree is shown by a row of fine wild specimens just to the south of the long bridge over the Bronx River, the largest trees within the grounds of the Garden. This tree is native of the eastern United States and yields a valuable lumber known as yellow poplar or whitewood; the Indians formerly made their canoes from this wood. The laurel family is represented by the sassafras, many trees of which may be found wild in various parts of the Garden. The sweet gum (Liquidambar), also wild in the grounds, represents the witch-hazel family.

The plane-trees are to be found just to the north of the elms. Here is a small tree of the oriental plane, native from southeastern Europe to India. A little to the southwest of this is a large specimen, native to the grounds, of the American plane, known also as the button-wood and button-ball, and there are many other wild trees along the Bronx River. The oriental plane is largely used as a shade tree in Europe and is sometimes planted in this country. The wood of the American plane, or button-wood, is largely used in the manufacture of boxes for tobacco, for furniture, and for the interior finishing of houses.

The apple family and the plum family are located to the north of the driveway leading to the long bridge. In the apple family may be found some of the tree hawthorns and thorns, including the Washington thorn, a native of the southeastern United States. Following to the west are some of the true apples (Malus), among them the Siberian 
crab-apple, a native of eastern Asia; the prune-leaved crabapple, a native of northern China and Japan; and Soulard's crab-apple, from the central United States. In the plum family, among others, may be found the rose-bud cherry, a Japanese plant, and a highly decorative species; the double form of the Japanese flowering cherry, native throughout eastern Asia; the ordinary sweet cherry, originally from Europe and western Asia, a delicious fruit, of which there are many horticultural forms; and the ever-blooming cherry.

Near the eastern end of the long bridge are trees illustrating the senna family, located south of the bridge approach, and the pea family, the rue family and the mahogany family on the north side. One of those in the senna family is the honey-locust or three-horned acacia (Gleditsia), a native of the southeastern United States; its durability when in contact with the ground makes its wood of especial value for fence posts, for which purpose it is largely used; from China and Japan comes the Japanese locust, also represented here. Another of this family is the Kentucky coffee-tree, in several large and small specimens. One of the representatives of the pea family, from the Amur region, is the Amur yellowwood (Maackia). Another is the locust-tree (Robinia), a native of the southeastern United States, but extensively naturalized elsewhere; its wood is hard and close-grained, and is very durable when in contact with ground or with water, so the high value in which it is held for fence posts and for ship-building may be readily understood. The rue family has for representatives the Japanese cork-tree (Phellodendron), from Japan, and the Chinese cork-tree, from the Amur region, China and Japan. The mahogany-tree family has a single species represented, the Chinese bastard-cedar, a native of China; the mahogany tree itself, and other representatives of the family, will be found at the conservatories.

On the ridge to the northeast of the apple family, and to the west of conservatory range No. 2, are trees of the ailanthus family, represented by the Ailanthus, or tree-of-heaven, a native of China, but extensively naturalized in the eastern 



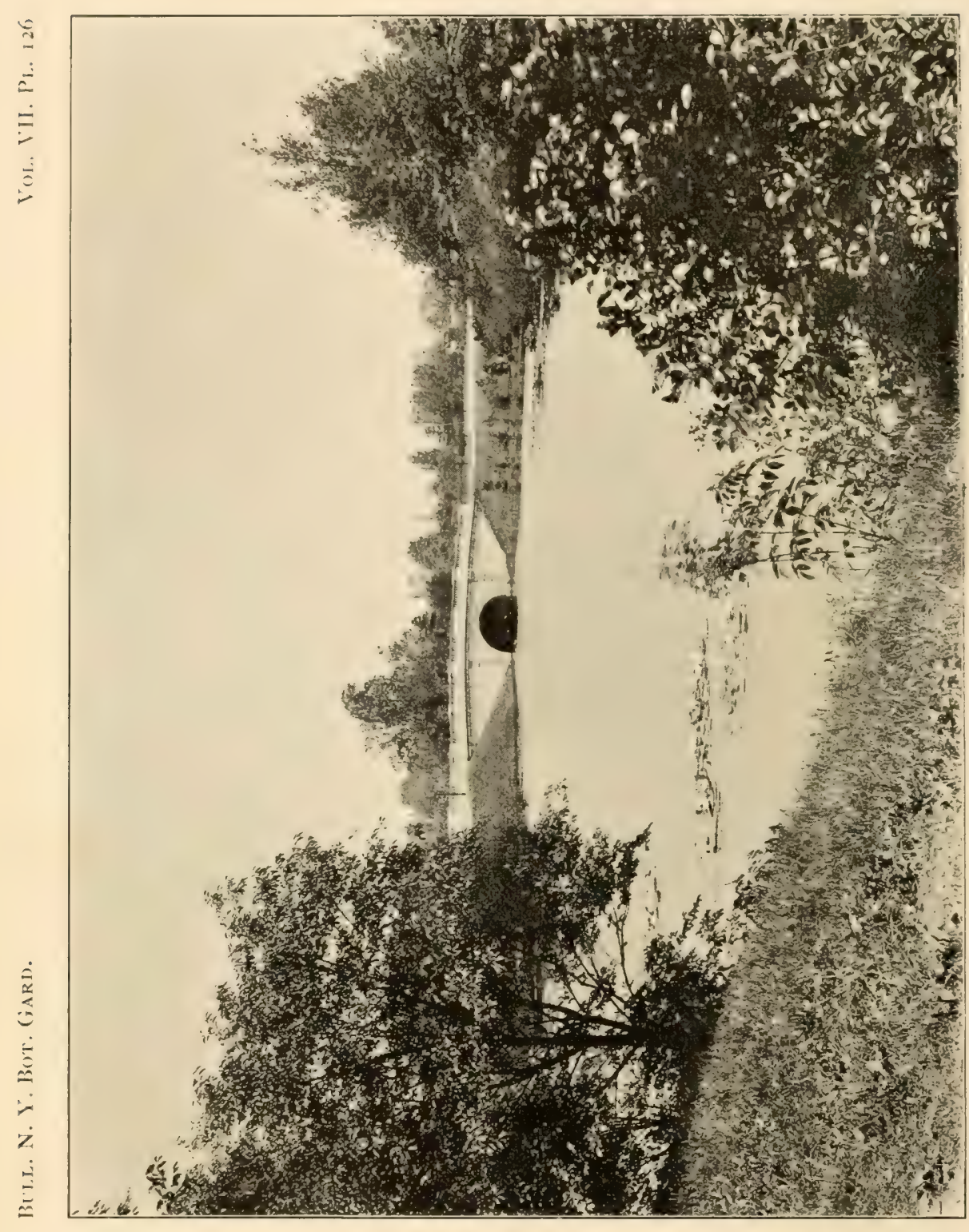

돈 
parts of the United States, where in some places it has become a nuisance, both on account of its ill-smelling staminate flowers and its habit of freely suckering from the roots.

On the ridge to the west of conservatory range No. 2 are the maple and buckeye families. The maples (Acer) are represented by a number of species. Perhaps the most important of these is the sugar, or rock maple, a native of eastern North America, and the principal tree yielding maple sugar and syrup. The sap is usually collected from late in February to early in April; trees from twenty to thirty years old are considered the most productive, and a tree will usually yield in a season from four to six pounds of sugar, some giving less and others much more. This tree is often planted for shade along streets and in parks, its beautiful coloring in the fall enhancing its value for this purpose. Its wood is largely used for making furniture, in ship-building, for toolhandles and for shoe-lasts and pegs. Another tree here is the red maple, ranging throughout eastern North America; its wood is now used in large quantities for the manufacture of furniture of various kinds, for gun-stocks, etc. The striped, or goose-foot maple, sometimes known also as moosewood, of northeastern North America, is a pretty decorative species, especially attractive on account of the beautiful marking of its bark. Two Old World representatives are the common European maple, of Europe and western Asia, and the sycamore maple, from Europe and the Orient. The sycamore maple is a valuable timber tree in Europe; its wood is used in the manufacture of musical instruments, spoons and other household utensils. From the southeastern United States comes the white-barked maple, also in the collection. The ash-leaved maple, or box elder, of eastern North America, is represented by several specimens.

In the buckeye family, planted near power house No. 2, is the common horse-chestnut (Aesculus); for a long time the native country of this tree was unknown, and its home was ascribed by different authors to various lands; it has been pretty well established now that it is indigenous to the moun- 
tains of Greece. Another tree here is the fetid, or Ohio buckeye, of the central United States; its wood, as well as that of some of the other kinds of buckeye, is manufactured into artificial limbs, for which purpose it is highly esteemed; it is also used for wooden-ware and paper pulp. To the north of the buckeye family is the linden family. The American linden, or basswood, found over the eastern parts of North America, is here; it produces a large amount of lumber under the name of whitewood, which is used in the manufacture of wooden-ware, furniture and carriage bodies; it is also largely used in the manufacture of paper pulp. Another species is the cordate linden, a native of Europe and Siberia, and a third is the white, or silver linden of eastern Europe.

Next in the sequence comes the ginseng family, represented by several species of aralia; many other species of this family may be found at the conservatories. West of these is the ebony family, represented by the persimmon or date-plum (Diospyros), a native of the southeastern United States; its wood is preferred for the manufacture of shuttles; its fruit contains tannin, which gives it its astringent properties; this fruit, when fully ripe, is eaten in large quantities in the southern states, and is also offered for sale in the markets of the north.

Beyond the ginseng family, on the western slope of the hill, is the olive family, represented by several species of the ashes (Fraxinus), some of which are useful for timber. The common European ash is to be seen, and among the North American representatives are the green ash; the Texas ash, restricted to that state; the Biltmore ash, from Pennsylvania to Georgia; the white ash and the red ash are common. Following to the north is the figwort family, represented by Paulownia, a native of Japan. Terminating the sequence is the trumpet-creeper family, represented by species of Catalpa; among these is the Indian bean, a native of woods in the Gulf States, and Kaempfer's catalpa, from China. 



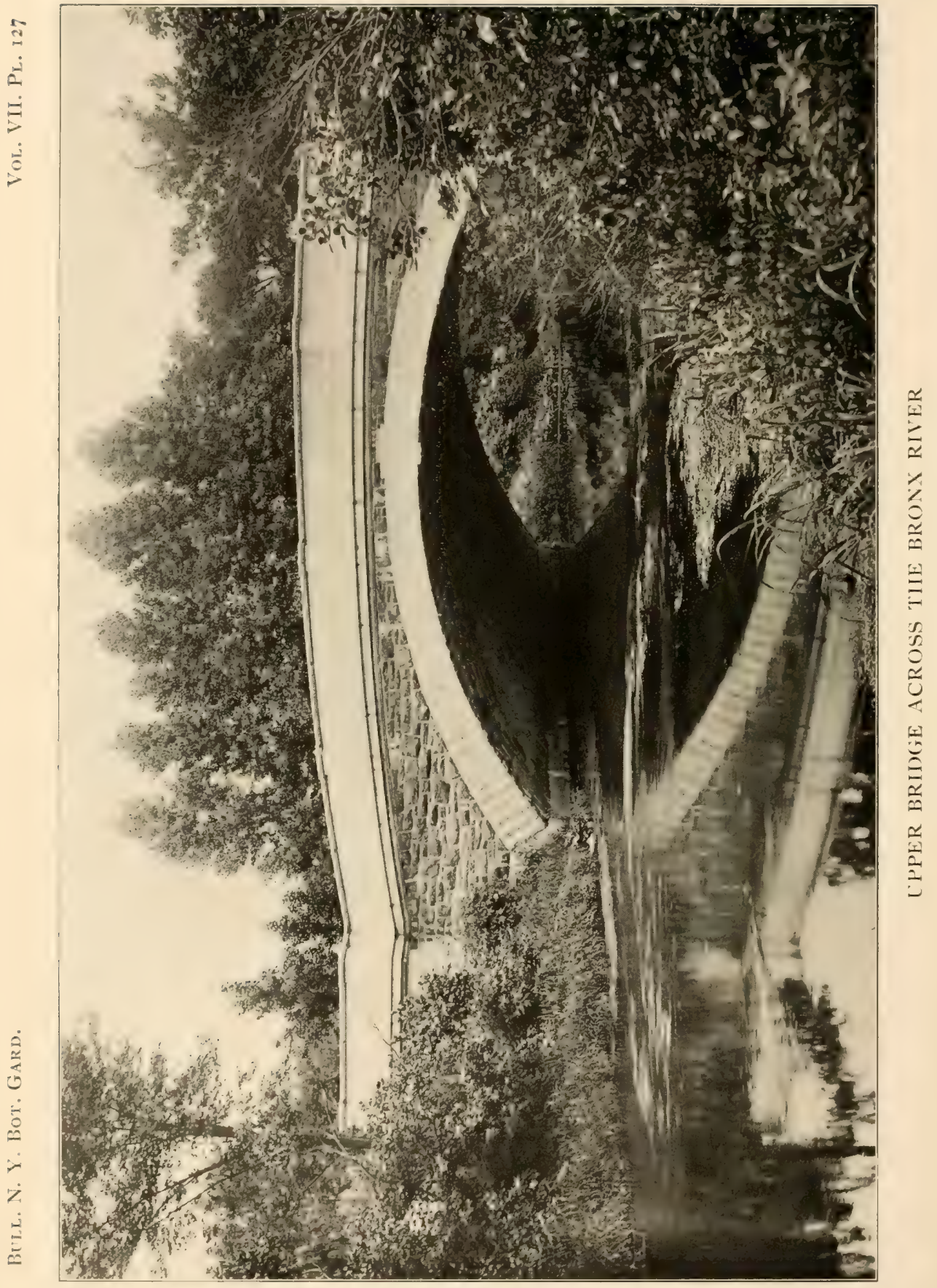




\section{The Hemlock Forest}

The forest of Canadian hemlock spruce along the Bronx River, within the portion of Bronx Park set apart for the New York Botanical Garden, is one of the most noteworthy natural features of the Borough of the Bronx, and has been characterized by a distinguished citizen as "the most precious natural possession of the city of New York."

This forest exists in the northern part of Bronx Park on the banks of the river and their contiguous hills; its greater area is on the western side of the stream, but it occupies a considerable space on the eastern side above the Lorillard mansion and below the boulder bridge. The area west of the river extends from just above this bridge down stream to a point nearly opposite the old Lorillard snuff mill, and is the part commonly designated "Hemlock Grove." Its total length along the river is approximately 3,000 feet; its greatest width, 900 feet, is at a point on the river about 700 feet above the water fall at the Lorillard mansion. The total area occupied by the trees on both sides of the river is between thirty-five and forty acres.

While this area is mostly covered by the hemlock spruces, and although they form its predominant vegetation, other trees are by no means lacking; beech, chestnut, sweet birch, red maple, hickory, oaks, dogwood, tulip-tree and other trees occur, and their foliage protects the hemlocks from the sun in summer to a very considerable extent; there are no coniferous trees other than the hemlock, however, within the forest proper. The shade is too dense for the existence of much low vegetation, and this is also unable to grow at all vigorously in the soil formed largely of the decaying resinous hemlock leaves; it is only in open places left by the occasional uprooting of a tree or trees by gales that we see any considerable number of shrubs or herbaceous plants, their seeds brought into the forest by wind or by birds. In fact, the floor of the forest is characteristically devoid of vegetation, a feature shown by other forests of hemlock situated further north. The contrast in passing from the hemlock woods to 
the contiguous hardwood area which borders them to the west and north, toward the museum building and the herbaceous grounds, is at once apparent, for here we see a luxuriant growth of shrubs and of herbs, including many of our most interesting wild flowers.

\section{The Gorge of the Bronx River}

The gorge of the Bronx River extends from the boulder bridge at the north end of the Hemlock Forest southward for about a mile, nearly to Pelham Avenue, and is a most beautiful and picturesque natural feature, besides being of great geological significance. Its depth from the summits of the hills on both sides averages nearly 75 feet, and its sides below the foot-bridge at the Lorillard mansion are nearly vertical rock faces. The hills on both sides are heavily wooded with hemlock spruces and other trees. In the upper part of the gorge the Bronx flows slowly, being held back by the dam forming the water-fall at the Lorillard mansion, and the elevation of its surface is only a few inches higher at the boulder bridge than it is at the fall; after plunging over the dam, however, the river runs in its unobstructed natural channel with all the appearance of a mountain stream, which at high water is exceedingly beautiful.

\section{North Meadows and River Woods}

The Bronx River enters the northern end of the Garden from Williamsbridge and flows as a slow stream southward to the water-fall at the Lorillard mansion, its surface being nearly level throughout this distance. It is spanned just inside the northern boundary of the Garden by a concretesteel arched bridge with granite copings, which carries the main park driveway across it near the Newell Avenue entrance. The entire northern end of the Garden is formed of the flood plain of the Bronx River, consisting largely of grassy meadows and marshes which at average flow of the stream are several feet above its surface, but which at flood time are occasionally submerged for short periods, the whole 



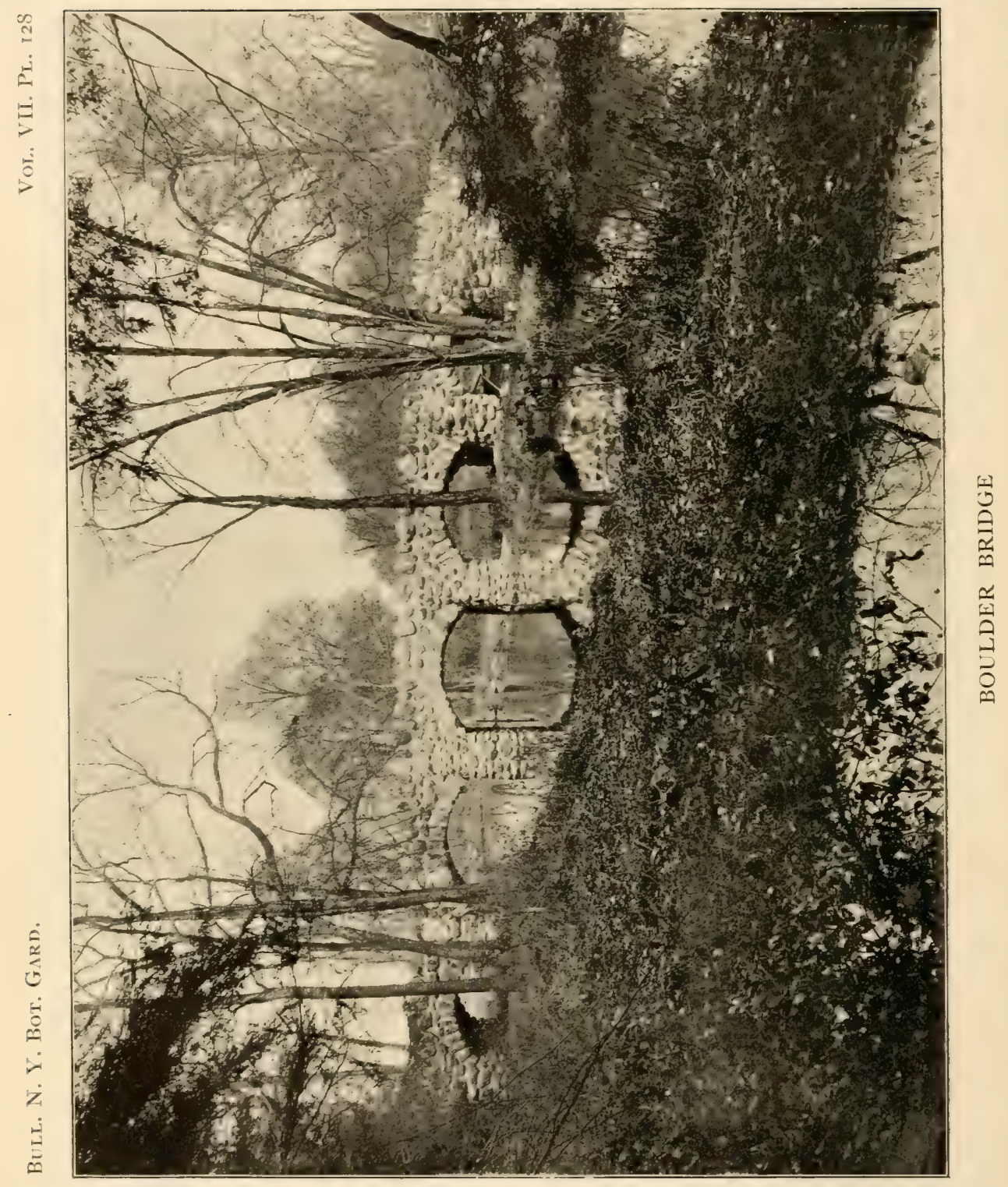


valley being a very interesting illustration of the behavior of a small stream with a large water-shed at and about its sources. Considerable areas of the marshy land have already been reclaimed by filling, and by the lowering of the dam forming the water-fall at the Lorillard mansion; the general plan contemplates a much further reduction in the amount of marshy ground, and a further lowering and deepening of the river by dredging, in order to take off freshets with greater rapidity. A part of this flood plain is occupied by the plantations of willows and poplars already described, and these will be considerably extended, but large areas of meadow will be left in their natural condition.

South of these open meadows, the valley of the river is much narrower and is occupied by several acres of characteristic river woods, containing a considerable variety of native trees and shrubs, extending south as far as the long driveway bridge near the northern end of the hemlock forest.

\section{Park Features}

The whole plan of the development of the Garden has been designed in such a manner as to include all the features of a public park, and it has been carried out in close coöperation with successive park commissioners and engineers of the Borough of the Bronx. The grounds are open to the public every day in the year without any charge whatever. An elaborate series of driveways provides several miles of Telford-Macadam roads, most of which are now constructed, with suitable entrances at eight points as follows:

I. Mosholu Parkway. 2. Bedford Park Avenue. 3. Southern Boulevard. 4. Hemlock Forest. 5. Southeastern entrance (not yet constructed). 6. Bleecker Street. 7 . Newell Avenue. 8. Woodlawn Road.

Paths located so as to lead to all the principal features are included in the plan, with an aggregate length of over ten miles and approximately one-half of this system has already been built. 
All the roads and paths have been located so as to do no damage to the natural features of the grounds, particular care having been taken to save all possible standing trees and to avoid disturbing natural slopes except in the immediate neighborhood of the large buildings, where considerable grading has been necessary, but even here the study has been to adjust the new surfaces so that they shall merge imperceptibly into the original ones. Ornamental masonry retaining walls, made necessary by the grades of the roadways, have been built at the Mosholu Parkway entrance, at the Woodlawn road entrance, and at the approach to the Elevated Railway station, and vines have been planted at the bases of these walls which partly clothe them with foliage.

The plan of the driveway and path systems called for the construction of six bridges; three of these, first, the lake bridge, crossing the valley of the lakes near the museum building; second, the long bridge, which carries the driveway across the valley of the Bronx River north of the hemlock forest; and, third, the upper bridge which crosses the Bronx River at the northern end of the Garden, have been carried out in masonry arches from designs by Mr. John R. Brinley, landscape engineer of the Garden. A stone boulder foot-bridge of five arches, just at the northern end of the hemlock forest was built from designs by the same engineer; studies have been made for a bridge to replace the wooden bridge which crosses the gorge of the Bronx River at the Lorillard mansion; and the sixth bridge in the plan is a footbridge, not yet built, to cross the Bronx River in the north meadows.

The park treatment further contemplates the planting of shade trees where these are needed along the driveways, and much of this has been done, a great many kinds of trees having been used, and many shrub plantations have been set out, especially at roadway and path intersections, utilizing considerable numbers of the same kinds of shrubs at different points. 



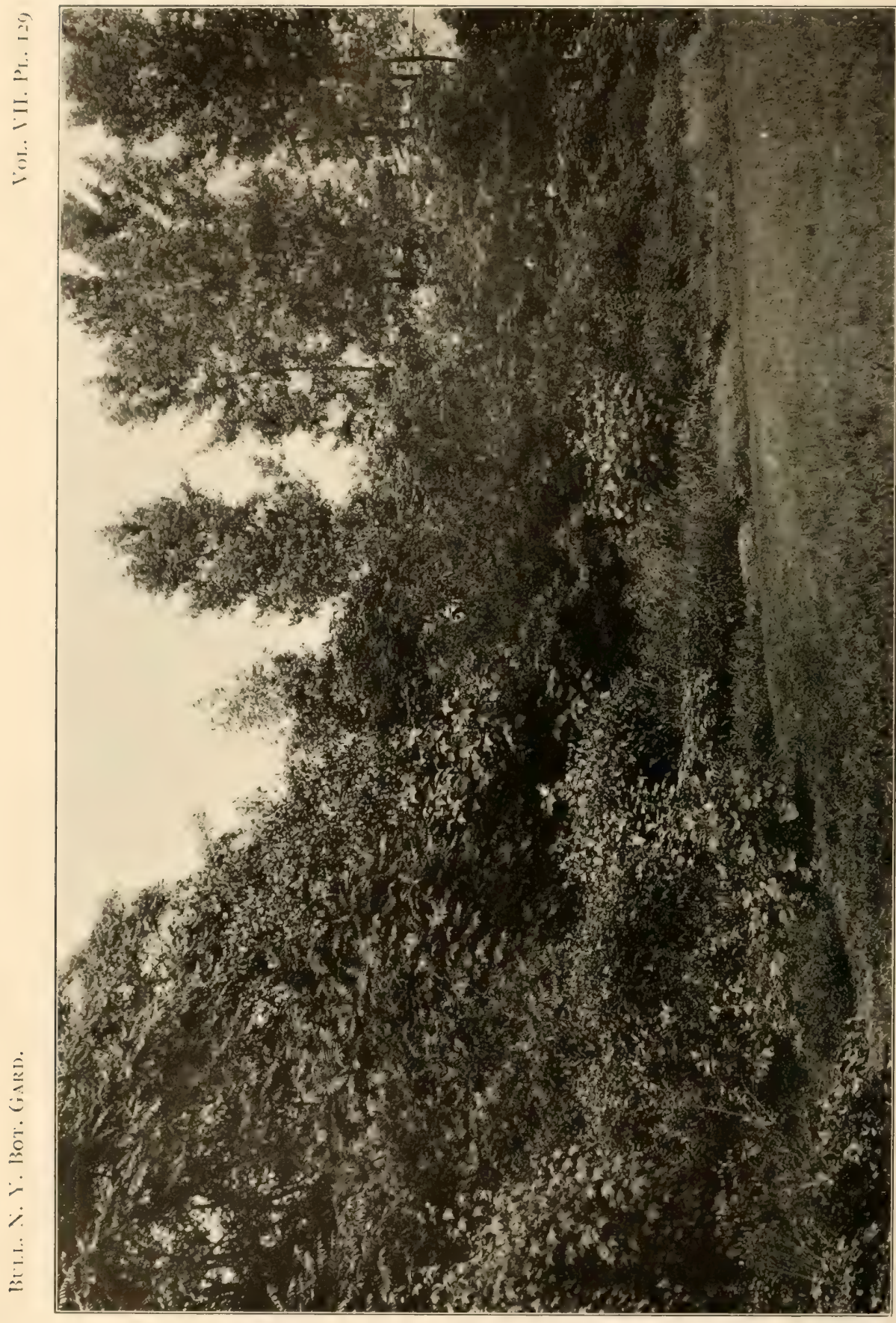

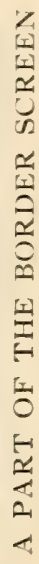


The drainage of the grounds has been carried out in accordance with a well-studied original plan, which provides outlets for the surface drainage for the most part either into the lakes or into the river, only a small portion of it being taken into the sewers; a considerable portion of the drainage system still remains to be built.

The water supply has also been constructed in accordance with the general plan and the system is being extended from year to year as the development of the grounds proceeds.

The general planting plan includes provision for completely surrounding the grounds, except at entrances, with border screens. This planting has already been accomplished along the entire western and northern boundaries, and partly along the southern boundary. These screens are composed of a very great variety of trees and shrubs, variously grouped, and average about fifty feet in width. It has not been practicable hitherto to plant these screens along the eastern border of the park on account of being obliged to wait for the construction of the street known as the Bronx Boulevard or Bronx Park East, the land for which has recently been secured by the city by condemnation proceedings.

A feature of this border screen is an old-fashioned flower border, composed of herbaceous plants in large variety, which extends from the 20oth Street, or Bedford Park Avenue, entrance northward to the New York Central Railroad Station and thence to the Mosholu Parkway entrance, and there is a similar plantation at the Elevated Railroad station; here herbaceous perennials are massed in front of a belt of flowering shrubs which in turn are backed by the trees of the border screen, and so selected that some of them are in bloom throughout the season. Among the plants used in this old-fashioned flower border are daffodils, crocuses, irises, phloxes, paeonies, rose mallows, sun-flowers, cone-flowers, coreopsis, columbines and many others. 


\section{Guides}

In order to provide a method for viewing the collections under guidance, an aid leaves the front door of the Museum Building every week-day afternoon at 3 o'clock, to escort all who may wish to accompany him. The routes are as follows:

Monday: Hemlock Forest and Herbaceous Garden. Tuesday: Pinetum. Wednesday: Fruticetum and North Meadows. Thursday: Deciduous Arboretum, Nurseries, Propagating Houses. Friday: Public Conservatories. Saturday: Museums.

\section{City Ordinances}

I. The picking of flowers, leaves, fruits, nuts, or the breaking of branches of any plants, either wild or cultivated, the uprooting of plants of any kind, the defacing of trees, and the carrying of flowers, fruits or plants into or from the grounds of the Garden, are prohibited, except by written permission of the Director-in-Chief of the Garden.

2. Leaving or depositing paper, boxes, glass or rubbish of any kind within the grounds of the Garden is forbidden.

3. Dogs are not allowed within the limits of the Garden except in leash.

4. It is forbidden to take fish from within the Garden, or to molest in any way squirrels, birds, snakes, frogs, toads, turtles or any other wild animals.

5. Throwing stones or other missiles, playing ball, football, tennis, or other game is prohibited.

6. It is forbidden to offer for sale food, candy, newspapers, books, tobacco, beverages, flowers or any other objects, without written permission from the Director-in-Chief and the Commissioner of Parks for the Borough of the Bronx.

7. Boating or rafting on the ponds, lakes and streams is forbidden.

8. Trucking, or the driving of business wagons of any kind, is forbidden on the roads of the Garden, except on those designated for such purposes. 
I. Public Conservatories, Range $\mathrm{I}$.

2. Elevated Railway Station.

3. Power House.

4. Bedford Park Avenue Entrance.

5. New York Central Railroad Station.

6. Mosholu Parkway Entrance.

7. Museum Building.

9. Southern Boulevard Entrance.

10. Herbaceons Grounds.

11. Morphological Garden.

2. Economic Garden.

13. Viticetum.

14. Deciduous Woodlands.

15. Hemlock Forest.

16. Bronx Park Entrance.

17. Gorge of the Bronx River

18. Water-fall.
19. Boulder Foot-bridge.

20. Long Driveway Bridge

2I. Lake Driveway Bridge.

22. Lakes.

23. Fruticetum

24. Woodlawn Road Entrance.

25. Salicetum.

26. Upper Driveway Bridge.

27. Bronx River.

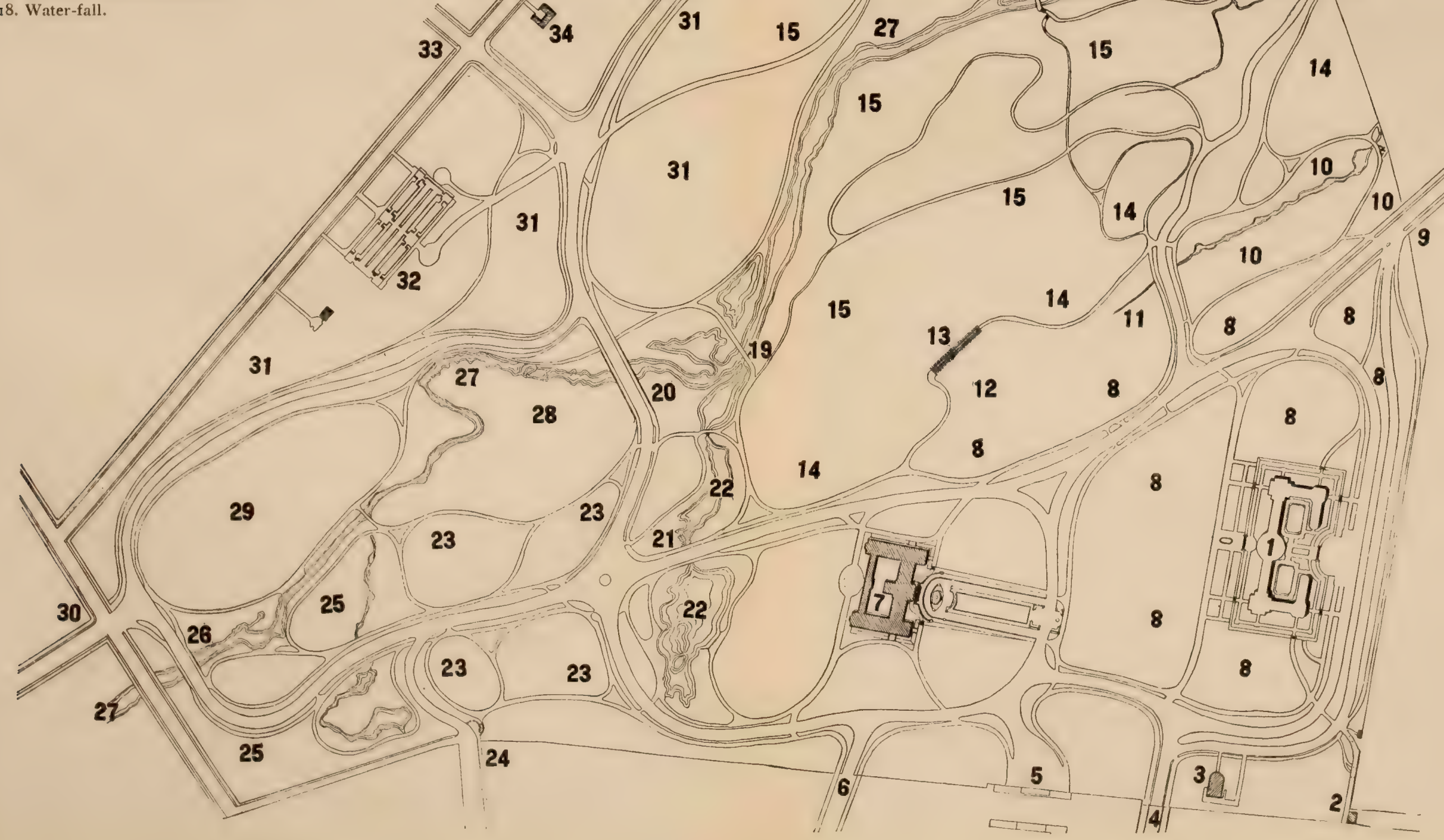





\section{(89)}

9. It is forbidden to accept or solicit passengers for any cab, carriage, or other conveyance, at any point within the grounds of the Garden without written permission from the Director-in-Chief of the Garden and the Commissioner of Parks for the Borough of the Bronx.

ro. Visitors are not allowed within the Garden after eleven o'clock at night nor before six o'clock in the morning, except upon driveways and paths designated for their use between those hours. 


\title{
APPENDIX \\ NATIVE TREES OF THE HUDSON RIVER VALLEY*
}

\author{
By Norman TAYLoR
}

The valley of the Hudson River contains most of the trees native in the northeastern United States. It is probable that all species which grew there at the time of Henry Hudson's visit in 1609, grow there today, although, owing to the clearing of land for agricultural purposes, and to the cutting of forests for wood, the number of individuals of most kinds has been much reduced.

In the following account, the trees known to grow naturally in the counties of New York and New Jersey which border the Hudson River have been included. A few of the species may not occur immediately within the topographical area of the valley itself but all the others might have been seen by the explorers.

\section{White Pine}

Pinus Strobus

The white pine, one of the most beautiful and the best known of our native evergreens, is a tall tree reaching a maximum height of 200 feet in some parts of the country; but in the Hudson Valley it is never so tall as this. The trunk is continuous, but in some rare cases it forks. The bark is fissured on the old trunks, but smoother and greenish-red on the young ones. The system of branching is very characteristic and exceedingly graceful. The upper branches are somewhat erect, but the middle and lower ones stand out

* This descriptive list of trees growing naturally near the Hudson River has been prepared at the request of the Hudson-Fulton Celebration Commission.

N. L. B. 


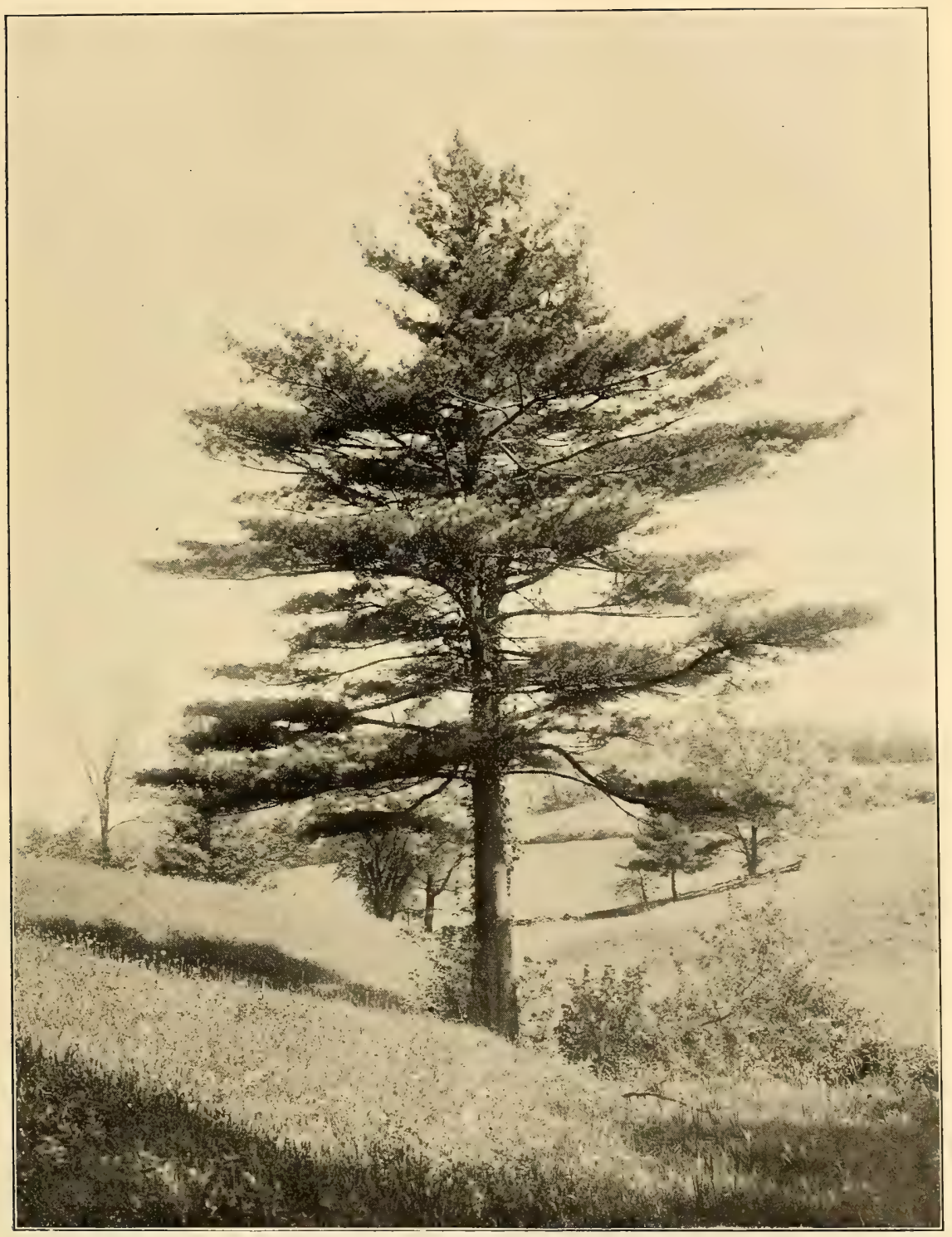

WHITE PINE

New Baltimore, Greene County, N. Y. 

straight from the trunk, or even droop a little at their tips when old. As in all pines the leaves are very slender and sharp-pointed, whence the name "pine-needles." Unlike all the other Hudson Valley pines this species has five of these needles in a cluster; there is a little tubular sheath enclosing the bases of the leaves when young. In the white pine the leaves are from 3 to 5 inches long and pale green or bluishgreen in color.

The flowers, which appear in May or June, and the subsequent seeds, are found at the bases of scales, the pistillate of which collectively form the well known "pine-cone." During the second year the scales of the cone loosen and release the winged seeds.

The white pine prefers sandy slopes and is found in all the counties bordering the Hudson Valley; rare and local on Staten Island, but abundant northward. Its timber is very valuable and few forests of it remain uncut. (Plate I3I.)

\section{Pitch Pine}

PINUs RIGIDA

The pitch pine, a round-topped but often irregularly shaped evergreen, attains a height of 50 or 60 feet. The bark is coarse, irregularly and deeply fissured when old, and red-brown in color. The branches are stiff and stand out straight from the trunk, in age becoming twisted and irregular.

The bright green leaves are arranged in clusters of three, enclosed at the base by a sheath, and persistent for 2 or 3 years. They are stout, sharply but closely toothed and from $2 \mathrm{~T} / 2$ to 5 inches long.

The flowers come out in spring, the pistillate or "cones" being almost without stalks and arranged in clusters along the sides of the branches. They are scarcely more than $21 / 2$ inches long and globose or ovoid in outline. The scales of the cone, which are armed with strongly recurved prickles, spread to release the seed during the second season.

The wood of the pitch pine is used for a variety of pur- 
poses where coarse lumber is needed. As a source of turpentine it has been superceded by the southern long-leaved pine. We find it growing freely throughout the lower part of the Hudson Valley, and it forms most of the "pine-barrens" of Long Island and New Jersey. (Plate I32.)

Short-leaved Pine Pinus echinata

On Staten Island and in adjacent New Jersey the shortleaved pine reaches its most northerly known stations. The trunk is tall and somewhat tapering, and usually bears numerous branches that are slender and droop at the tip. The old bark is roughly fissured and usually reddish in color.

The leaves of the short-leaved pine are mostly in clusters of twos or threes. The bases of the leaves are enclosed by a tubular sheath which stays on as long as the leaf still clings to the branch; in this pine the leaves often persist for three or even five years. The "needles" are from 2 to 5 inches long and sharp-pointed, their margins are closely and finely toothed, thus feeling rough to the touch.

The flowers come out in April or May and the pistillate or "pine-cone" are almost always found at the sides of the branches on short stalks. Occasionally they may grow on the ends of the branches. Two or three, sometimes four, grow together, and after they spread their scales, which are prickle-tipped, they often hang on the branches for several years.

In North Carolina this evergreen is often tapped for turpentine, and it is used very generally for woodworking. It grows in sandy or clayey situations from Texas to Florida and northward to southern New York.

\section{Scrub Pine}

Pinus virginiana

In the lower Hudson Valley the scrub or Jersey pine as it is sometimes called is scarcely more than 40 feet tall, but in the west it is often Ioo feet in height and 3 feet in diameter. The bark is reddish-brown and splits into large plates. The branches, several of which arise as successive whorls on the trunk, are slender and often drooping at their tips. 


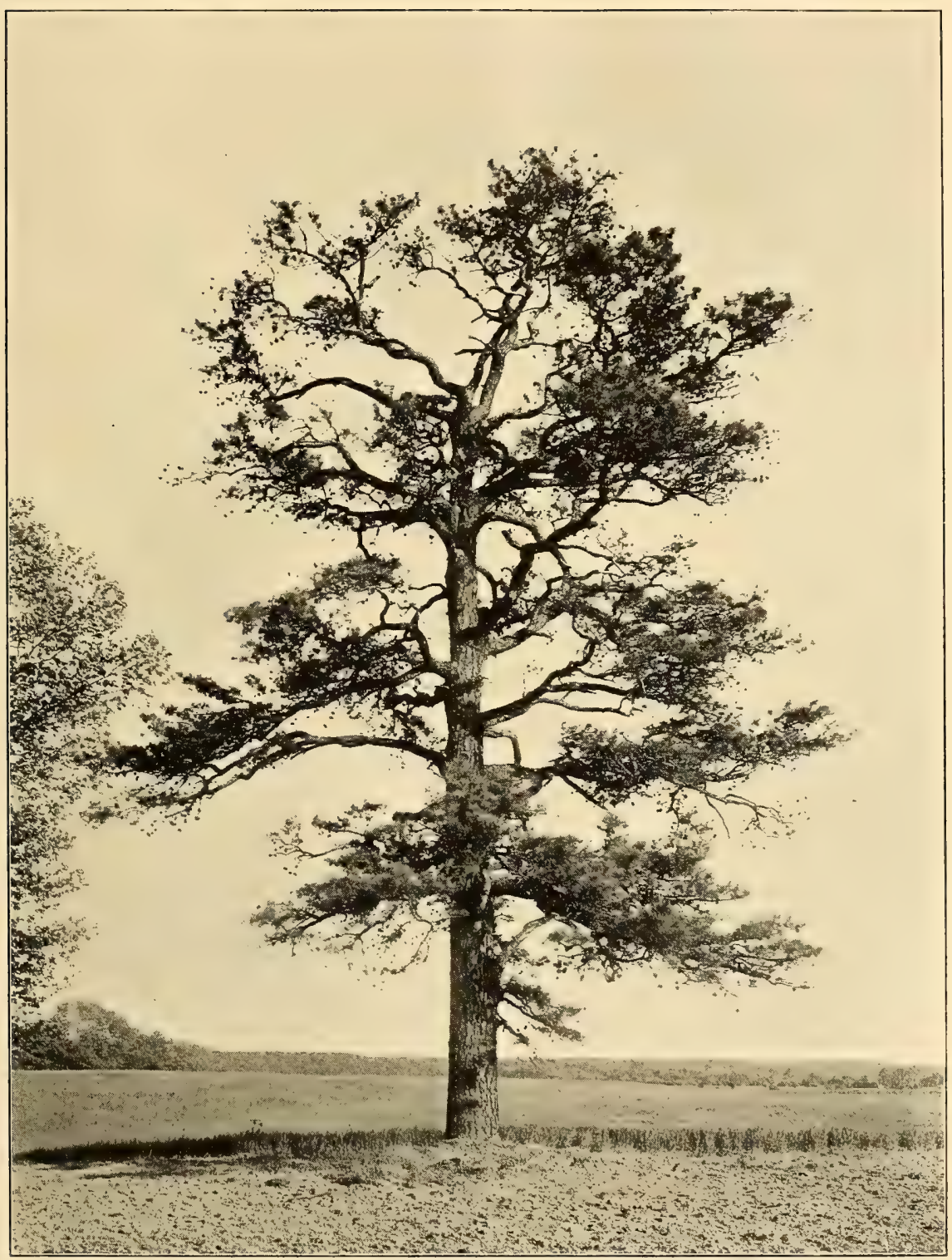

PITCH PINE

New Baltimore, Greene County, N. Y. 

The leaves of the scrub pine are twisted and this character serves to distinguish it from all the other pines of the Hudson Valley. The "needles" are from an inch and a half to two and a half inches long and arranged two in a cluster, their bases being enclosed in a persistent sheath.

The cones are without a stalk and usually attached to the side of a branch but sometimes at the end of it. When closed they are conical in outline, but become ovoid when the scales loosen to release the seers. The scales are prickletipped.

Commercially the tree is of little importance, the wood being soft and weak. It has little decorative value, except in picturesque masses, as it is more or less scraggy. It is much valued as a reforester, for it quickly covers burned or worn out areas. It reaches its northernmost limit on Staten Island and adjacent New Jersey.

Red Pine

Pinus RESINOSA

In favorable situations the red pine often attains a height of $\mathrm{I} 2 \mathrm{O}$ feet, and a trunk diameter of 3 to 4 feet. The tall straight trunk is clothed with scaly reddish bark that is only shallowly fissured.

The sharp-pointed "needles" are arranged in clusters of two, and their margins are minutely toothed. They are from 5 to 7 inches long, slender and flexible. The infertile flowers bloom in May, followed later by the fertile flowers and "cones." The latter are oblong in shape, from $2 \frac{1}{2}$ to $3 \mathrm{~T} / 2$ inches long, and composed of numerous scales that are turned backward at their tips, but are without prickles. These blunt-tipped scales of the cone distinguish this tree from all the other pines of the valley, except the white pine, from which the red pine differs in having only two leaves to a sheath instead of five.

The red pine is occasional in the upper Hudson Valley, and a record exists of its having once grown at Inwood on Manhattan Island. It is distributed from Nova Scotia to Minnesota and southward to the mountains of Pennsylvania. 


\section{American Larch}

LARIX LARICINA

The tamarack or larch is the only Hudson Valley conifer which loses all its leaves during a single season. It is a round-topped tree when young, but in age the branches often become contorted and consequently the whole tree is scraggy in appearance. The leaves are narrow, triangular in section, and bright green in color, becoming yellow before they fall in the autumn. They are usually not more than $\mathrm{I} / 2$ inches long and arranged in isolated little clusters. The flowers come out in spring and the pistillate or cones are scarcely more than three quarters of an inch long. They mature during the first season.

The larch usually grows in cold bogs where it may form dense forests. It reaches its southerly limit in Pennsylvania and West Virginia. The wood is much used for railway ties, ship construction and for telegraph poles.

\section{Swamp Spruce}

PICEA MARIANA

Within the Hudson Valley region the spruce, with the larch, seems to be confined to low bogs. Far north the tree grows on slopes and attains a height of roo feet, it is never so tall as this in our area. The bark is thin, closely fissured and brownish in color. As in all the spruces the leaves are four-sided; in this sort they are not more than a half inch long, sharp-pointed, and bluish-green in color. They are usually scattered on the hairy twigs. The pistillate flowers or cones are fastened to a strongly incurved stalk. They are oval in outline and composed of numerous small scales which are notched at the top. The tree may often be seen with cones several years old still clinging to the branches.

The wood of the swamp spruce is soft and is occasionally used as lumber, but it is now an important source of paper pulp. It grows practically throughout the northeastern part of the continent, coming down as far south as Pennsylvania and West Virginia.

The red spruce (Picea rubens) also growing in the Hudson Valley may be distinguished from the swamp spruce 
by its lustrous green leaves, by its early falling cones, and by the scales of the cones, which are scarcely ever notched. The red spruce is also used in making paper pulp and its sap furnishes the commercial spruce gum. It grows in a narrow belt from New Brunswick to Tennessee. Both these spruce trees are essentially northern plants, and in the Hudson Valley are more common near the mountains than southward.

\section{Hemlock Spruce}

Tsuga CANADENsis

The hemlock, one of our slow-growing evergreens, reaches its greatest development in the northern part of the continent. It frequently forms exclusive forests under favorable conditions, but southward the trees become scattered and intermingled with other kinds. One of the most southerly groves is that within the grounds of the Botanical Garden where the tree has practically exclusive control of a tract of some 35 acres. It is common along the Palisades.

The tree is sometimes as high as I 20 feet, with a stout trunk covered with a coarse roughly ridged bark. The branches stand out straight from the trunk when old or droop slightly at their tips. The arrangement of the twigs and leaves in a practically flat plane with the branch gives the tree a very characteristic and beautiful facies. Unlike the spruce the leaves of this hemlock are flat; they are bluish green on the under side and dark olive green on the upper. They are seldom more than $2 / 3$ inch long and rounded at the tip.

The cones mature the first season and shed their seeds during the winter; they are smaller than the cones of the pines, scarcely ever being more than $3 / 4$ inch long. They are usually found attached by a short stalk to the tips of the young branches.

The rough coarse lumber of the hemlock is used only for general construction purposes, and the tree is of economic importance almost solely on account of its bark which is an important agent in tanning leather. 
Balsam Fir

ABies baLsamea

The balsam fir occurs but sparingly in the lower Hudson Valley, it being chiefly a northern tree and abundant in the Adirondacks. It forms, when isolated, a broad, symmetrical tree of cone-like shape scarcely exceeding $75 \mathrm{ft}$. in height. The trunk is covered with a smooth gray bark which has numerous resinous blisters spread throughout it. The resin exuded is the well-known Canada balsam of commerce. The branches are arranged in successive and sometimes widely separated whorls; in age they droop slightly at their ends. There are usually two kinds of leaves on the balsam fir, those on the cone-bearing branches and those found only on branches not cone-bearing. On the former they are about $1 / 2$ inch long and sharp-pointed, but on the sterile branches they are twice as long and usually rounded at the tip.

The cones, which stand erect on the branches, instead of drooping as they do in most of our evergreens, are from 2 to 4 inches long and composed of numerous roundish scales. The tree may often be found with only the naked stalk of the cone clinging to the branch; as the scales fall off, from the top downwards, thus releasing the seeds, while the stalk is still fast to the branch.

This evergreen, which in the Hudson Valley region prefers moist situations, has been lately used in making paper, but for general purposes its wood is too soft and coarse-grained.

\section{Red Cedar}

JUNIPERUS VIRGINIANA

Because of its use in making moth-proof chests, and in the manufacture of lead-pencils, the red cedar or juniper, is one of the trees that comes more closely in touch with everyday affairs than almost any other Hudson Valley evergreen. It is common throughout the area in soil that will maintain scarcely any other trees, loves rocky and exposed places and will stand any amount of abuse from the elements.

The tree is tall, straight, and spire-like, with the lower branches somewhat spreading and the upper always erect. The trunk, which is covered with shedding, fibrous bark, is 


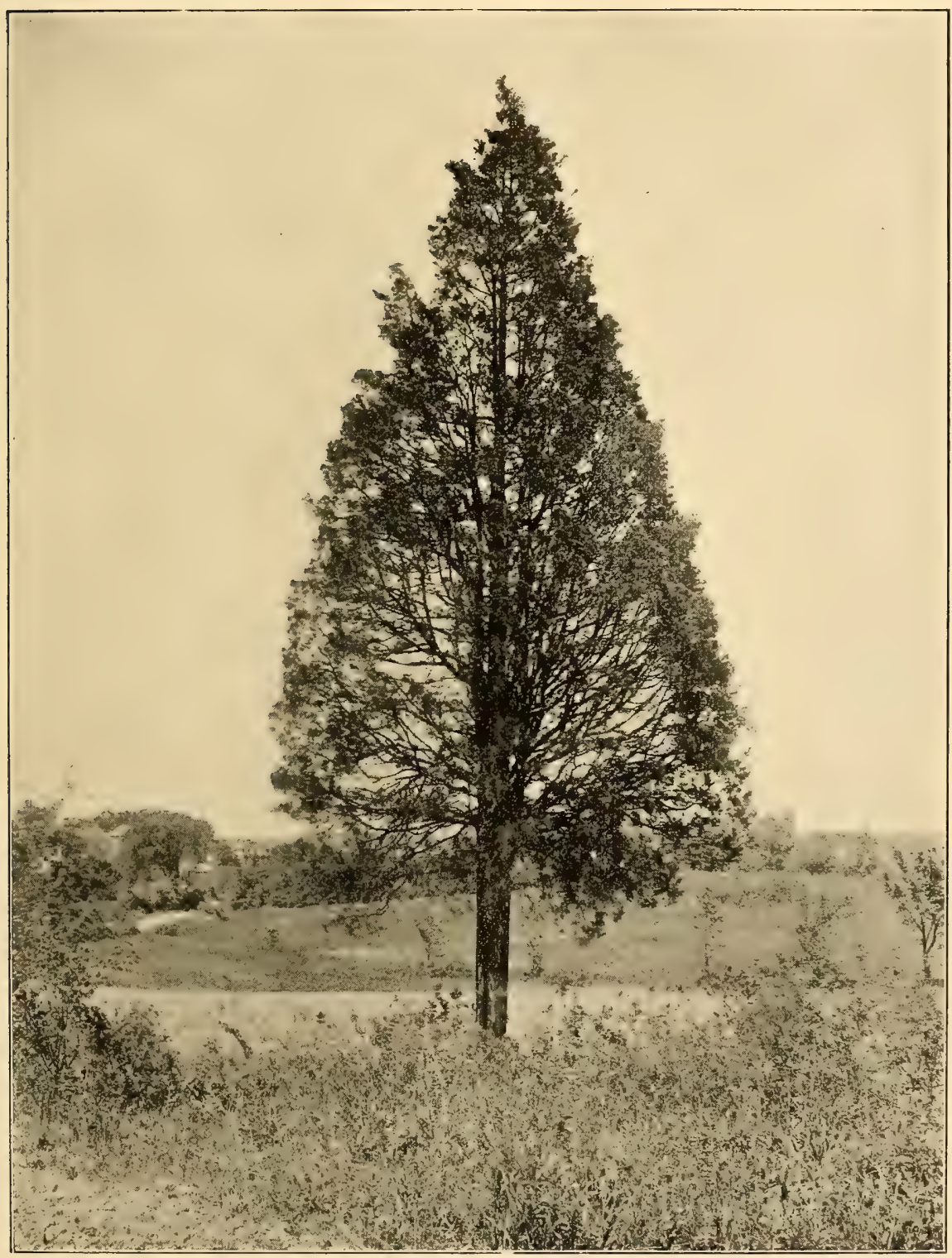

RED CEDAR

New Baltimore, Greene County, N. Y. 

fluted and often buttressed at the base. It has two kinds of leaves; those on the vigorous young shoots are awl-shaped, about $3 / 4$ in. long, and spreading from the twig. On the old branches the leaves are reduced to tiny scales which are pressed flat against the branches.

The flowers come out in early spring; those which subsequently form the fruits are never found on the same tree as the none-fruiting flowers. The fruits, which are cones, become pressed into a bluish berry-like structure, are $1 / 4$ inch in diameter, and almost smooth. (Plate I33.)

A single tree of the juniper (Juniperus communis) formerly grew near the south shore of Staten Island, where it may have been planted; on hillsides from Poughkeepsie northward we find the low juniper (Juniperus nana) as a round shrub scarcely over three feet high.

\section{Arbor-Vitae}

Thuja occidentalis

The arbor-vitae, or tree of life, is popularly much confused with the white cedar. It may be readily distinguished by its cones which are oblong and composed of several loose scales, instead of being spherical and with more or less compressed scales. In other respects the resemblances are striking and the differences not very apparent.

In favorable situations it may reach a height of $60 \mathrm{ft}$. The trunk is continuous or sometimes divided, fluted and often conspicuously buttressed at the base. The horizontal branches frequently curve upwards at the tip. The small scale-like leaves are pressed closely to the frond-like, usually fan-shaped branchlets.

The flowers are usually reddish-brown, come out early in May and mature during the season. The cones are cinnamon-brown, ripen and shed their seeds in the autumn, but cling to the branches during the following winter.

Shingles, fence-posts and many other articles are made from the wood of the arbor-vitae, and the highly aromatic twigs and leaves are much prized. It grows in moist situations from New Brunswick to West Virginia and westward 
to Minnesota. It is common in the Highlands of the Hudson. Owing to its popularity for decorative planting it has become the progenitor of at least fifty different horticultural varieties.

\section{White Cedar}

Chamaecyparis Thyoldes

The white cedar, a tree from 70 to $80 \mathrm{ft}$. in height, is the swamp evergreen par excellence. It occurs from Maine to Florida and often forms exclusive forests; it grows in many parts of New Jersey. The horizontal branches which become more erect near the top give to the tree a spire-like conical shape. The branchlets are usually arranged in flat fan-like clusters and thus give a very characteristic appearance to the whole tree.

As in the red cedar there are two kinds of leaves; those on the young shoots are sharp-pointed, ridged on the back, and spreading from the stem. But the greater number of the leaves are pressed flat against the stem, are scarcely more than $1 / 2$ inch long, and more scale-like than leaf-like. They turn russet brown during the winter and may drop off the second year but many of them cling to the branches for several years.

Unlike the red cedar, this tree has cones that are truly cone-like and not so compressed as to resemble berries. The cones are scarcely more than $1 / 4$ inch in diameter, almost spherical, gray-green at first but subsequently bluish-purple or reddish-brown.

The wood of the white cedar is not nearly so fragrant as that of the red cedar, but it is used in ship-building and for a variety of construction purposes.

\section{Swamp Poplar}

Populus heterophylla

The swamp poplar is common only in the southern part of the Hudson Valley. A few trees are known to grow in the Highlands but above this point it is rare. It grows plentifully along the Atlantic seaboard as far south as Georgia, and prefers moist or inundated situations. 
In the north the tree is scarcely more than $50 \mathrm{ft}$. in height; in the south it is often twice this size. The trunk, which is covered with gray-brown bark, is mostly continuous, and bears towards the top the slender spreading branches. The leaf-blades, which are hoary when very young, subsequently become bright green and smooth. The leaf stalk is round, and consequently the leaves do not quiver in the breeze as they do in nearly all the other Hudson Valley poplars.

The flowers are of two kinds, those which subsequently produce fruit and those which do not. Almost always the two kinds are found on different trees, and they come out in April and May, usually before the leaves. The flower cluster, or catkin, is about 2 or 3 inches long. The fruits mature in May or June, and are filled with the seeds which are closely invested with silky, white or orange hairs.

The wood is of little economic importance, although under the name of black poplar it has been used in interior decorating and finishing.

\section{Balsam Poplar}

Populus balsamifera

The balsam poplar, more or less of a swamp tree, occurs in the extreme northerly part of the Hudson Valley. It is known to be plentiful northward into Newfoundland and Hudson Bay, but becomes scarcer southward. It is a tall tree reaching a height of 100 feet and a trunk diameter of 4 feet. under favorable conditions. The bark and young twigs are reddish-gray; and the buds are conspicuously resinous.

\section{Balm of Gilead}

Populus candicans

The Balm of Gilead poplar, which may be distinguished by its bright green and smooth young leaves, with hairy stalks, is not known as a wild tree in the Hudson Valley. There are numerous specimens of this tree in the area but they are presumably derivatives of cultivated trees. The home of the Balm of Gilead is doubtful, but it has been stated to be Michigan and the country to the northwest. 
The Carolina poplar and the aspens may be readily distinguished from all the other native Hudson Valley poplars by their flattened leaf-stalks. To this flattening and consequent weakening may be traced the characteristic quivering of the leaves in the breeze.

The necklace poplar, as it is also called, is a tree rarely higher than 120 feet. The trunk is covered with smooth gray-green bark when young but in age the bark becomes rough and fissured. The branches are more or less spreading and stout. From the aspens of the Hudson Valley the Carolina poplar can be distinguished by its broadly triangular or delta-shaped leaf-blades, which are long-pointed at their tips. The flowers are so clustered as to form the familiar catkin, a peculiarity of all poplars. They bloom in April or May. Those catkins which subsequently bear the fruits elongate greatly after the blooming period.

The Carolina poplar grows best near water and it is found from Quebec to Florida and westward. It is common in the Hudson Valley.

The well-known Lombardy poplar (Populus italica) characterized by its rigidly erect branches, grows in the Hudson Valley only as an escape from cultivation. It is an Asiatic tree.

\section{American Aspen}

Populus tRemuloides

The American aspen or quaking aspen is a tree occasionally reaching a height of Ioo feet and a trunk diameter of 3 feet but in the Hudson Valley it is much smaller. The bark is pale yellow, becoming whitish. The spreading branches are remote, often contorted, and give the tree a round-topped outline.

The leaf-blades are dark green; oval in outline, with a rounded or wedge-shaped base and sharp-pointed tip. The teeth on the margin are small and have a tendency to be incurved. The leaf-stalk is flat and about as long as the leaf-blade. The gray-green flowers bloom in April and 
May, followed by the fruits about a month later, when the stalk of the catkin becomes greatly elongated.

The American aspen is a rapid grower, and consequently the wood is soft and of little commercial importance, except as a source of paper pulp. Tannin is extracted from the bark. It grows best on moist gravelly soil or hillsides in the area, but it is found quite generally throughout the northern part of the continent. It is common along the upper Hudson, and extends southward to Staten Island.

\section{Large-toothed Aspen}

Populus grandidentata

The tree may be distinguished from the common aspen by its leaves which are broader than in the latter. The teeth on the margin of the leaf-blade are at least twice as large as those on the aspen, and they are not incurved. The buds of the aspen are usually quite smooth but in the large-toothed aspen they are uniformly clothed with dense hairs.

This tree prefers moist soil near swamps or streams, and it is confined to the eastern part of Canada and the United States. It is known to grow throughout the Hudson Valley.

\section{Black Willow}

SALIX NIGRA

Most of the willows of the Hudson Valley are mere shrubs, but the black willow is a tree 30 to 40 feet high. There are a few more that very rarely become trees, although their characteristic habit is shrub-like. The bark of the black willow is dark brown or nearly black, but sometimes it is lighter brown tinged with orange. The branches are stout and spreading, giving the tree an open irregular head.

The leaves, which are alternately arranged on the reddish twigs, have lance-shaped blades from 3 to 6 inches long and are finely toothed on the margin. In age the leaf-blades may become scythe-shaped.

The flowers are clustered to form the well-known catkin. In the black willow they are found on short twigs, and bloom with the appearance of the leaves in early spring. 
The wood of the black willow is of little use except for fuel. The tree is found usually at the edges of streams, and grows plentifully from New Brunswick to Georgia and westward.

The weeping willow (Salix babylonica) is common in the Hudson Valley. It is an Asiatic tree, however, and rarely establishes itself as a wild element in our flora.

The white willow (Salix alba) which is botanically related to the weeping willow, is a European tree that is as much at home in this country as our native willows. It may be distinguished from the black willow by its leaves, which are whitish beneath.

Butternut

Juglans CINEREA

The butternut is a tree occasionally reaching a height of 80 feet in favorable situations. The trunk is scarcely ever continuous but divides about the middle and spreads out into several widely-spreading branches. The bark is usually brownish in color, coarse, and roughly fissured.

The leaves are compound, that is, they are composed of from I I to i 7 leaflets all attached to a common, hairy leafstalk. Each leaflet is more or less broadly lance-shaped and has an inequilateral base, which is attached directly to the common leaf-stalk, as the leaflets are themselves stalkless.

In the butternut the flowers bloom when the leaves are partly grown. They are in spike-like or catkin-like clusters. Those which are found in spike-like clusters subsequently develop into the fruits or "butternuts." The nut is ovalpointed, 4-ribbed and irregularly sculptured, and the sticky husk enclosing the nut is greenish and contains a violent yellow-green dye or stain.

The tree grows best in rich soil, either along streams or on low hillsides, and is found from Maine to Alabama and westward. It is common along the top of the Palisades and northward throughout the Hudson Valley, uncommon on Staten Island. It is of considerable economic importance for the wood is used in cabinet-making, the inner bark has 


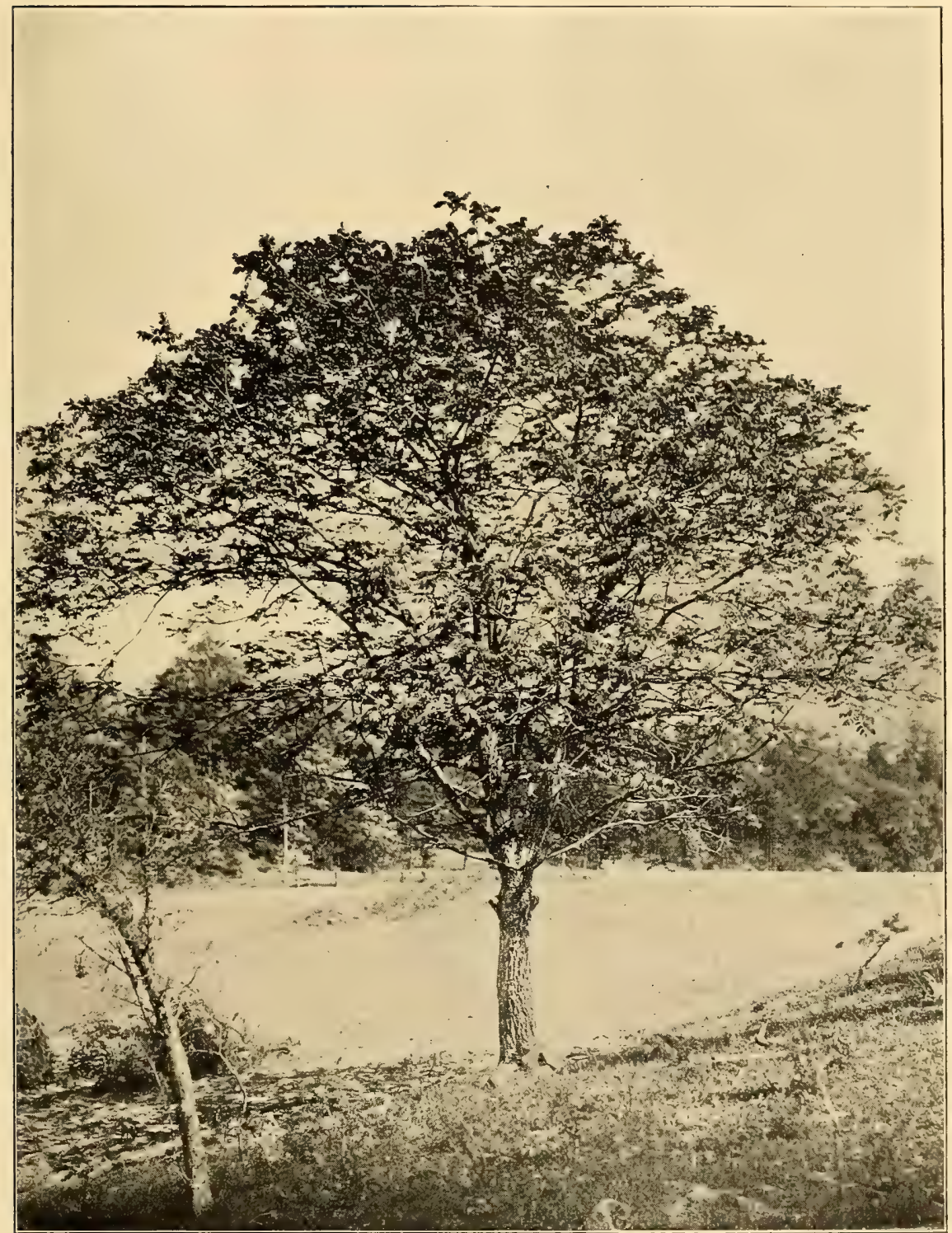

BUT'IERNUT

New Baltimore, Greene County, N. Y. 

medicinal properties and the outer bark yields a good sugar. (Plate I34.)

Black Walnut

JUGLANS NIGRA

Closely related, botanically, to the butternut is the black walnut. It is taller than the former, frequently reaching a height of 130 feet. The bark is coarse and prominently ridged; and it is a darker brown than in the butternut. The leaflets on the black walnut are more numerous, frequently exceeding 20 to a single common leaf-stalk. They are unequal at the base, practically stalkless, and their margins are sharply small-toothed.

As in the butternut the flowers are arranged in catkins or in spike-like clusters. Those which subsequently develop the fruits are yellowish-green tinged with red. Unlike the butternut the fruit of the black walnut is never 4-angled or ribbed. It is almost perfectly round, the shell slightly sculptured, and covered with a thick husk.

The wood of the black walnut has become famous for its beautiful markings, the so-called figured trees being of almost fabulous value for the manufacture of furniture. Extensive forests of it once flourished throughout the eastern part of the United States, but it is now comparatively scarce. It grows in the vicinity of West Point and in the Highlands generally, southward to Staten Island, but it is less common than formerly.

\section{Mocker-Nut Hickory}

HICORIA ALBA

In the autumn the mocker-nut will be found retaining its foliage longer than most other hickories. It is a tall tree, often reaching a height of 90 feet, and a trunk diameter of 3 feet. The trunk is usually continuous in the forest, but branched and forked when the tree grows in the open. The irregularly fissured close bark is characteristic and serves to distinguish it from the shag-bark hickories, where the bark is regularly fissured and splits off in large plates.

In the mocker-nut, as in all hickories, the leaves are com- 
pound, being composed of from 5 to 9 hairy leaflets, all attached to a common hairy leaf-stalk. The leaflets are oblong or lance-shaped, sharp-pointed at the tip, and wedgeshaped at the base. They are practically equilateral. In May or June the catkin-like flowers appear, followed in the fall by the well-known edible mocker-nut. The splitting of the husk of the mocker-nut serves to distinguish it from the pignut, in which the husk of the nut does not split.

The tree grows naturally from Maine to Florida, Nebraska and Texas, and it was at one time common on Manhattan Island. The hard, strong wood is indiscriminately classed with the other hickories by lumbermen.

\section{Bitter-Nut}

HICORIA CORDIFORMIS

Because of its inequilateral and curved leaflets, the bitternut may be easily distinguished from the preceding, with which, in other respects, it might be confused. It is a tall, quickly growing hickory, quite commonly distributed from Massachusetts to Georgia and westward; and is found in fair abundance along the Hudson Valley. The wood is largely used for fuel, and also for making implement handles and hooks. Its thin-shelled nut is very astringent.

\section{Shagbark Hickory}

HiCORIA OVATA

In the Hudson Valley the shagbark, or shellbark as it is sometimes called, is one of the two hickories in which the bark splits off in long plates. The whole trunk is covered with the pieces of bark clinging at their upper edges and free from the trunk at the lower, thus giving the trunk its strikingly shaggy appearance.

It rarely reaches a height of I oo feet, and usually does not have a trunk diameter of more than 2 to 3 feet.

There are usually only 5 leaflets in this kind of hickory, but sometimes 7 leaflets may be found. The leaflets are almost equilateral, and wedge-shaped at the base. The catkin-like flower clusters come out in May followed by the fruits in the fall. The nut, which is the common hickory 


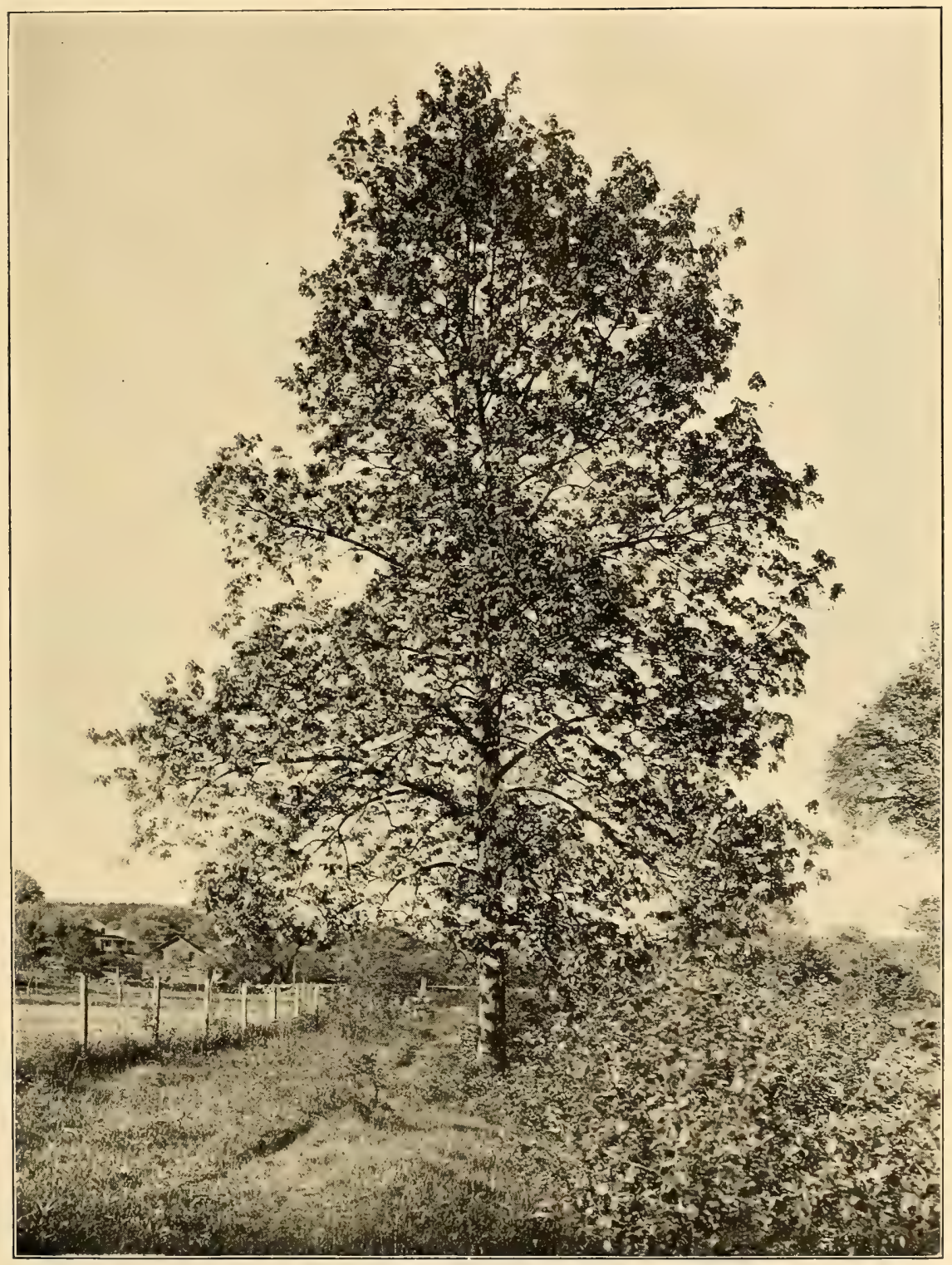

SHAGBARK IICKORY

New Baltimore, Greene County, N. Y. 

nut of commerce, is slightly flattened at the top, 4-sided and closely invested with a husk which splits all the way down to the base.

The range of this valuable tree is from Maine to Georgia; in the Hudson Valley it is common. The hard tough wood is much prized in making tool handles. (Plate I35.)

\section{Small-fruited Hickory}

HiCORIA MICROCARPA

There are two Hudson Valley hickories that have shaggy bark. The small-fruited hickory may at once be distinguished by the husk of its smaller nut which does not split all the way to the base, as it does in the common shagbark hickory. The splitting plates of the bark are smaller, and consequently the trunk is not so distinctly shaggy.

The small-fruited hickory, which is a large tree, often reaching a height of 80 feet, grows commonly in the same situations as, and often with, the shag-bark hickory; it is known to occur only from New York to North Carolina and westward to Missouri. It is comparatively common on Staten Island but scarcer northward. (Plate I36.)

\section{Pignut Hickory}

HICORIA GLABRA

The pignut prefers drier ground than most of the other hickories. It is often as much as Ioo feet in height and with a trunk diameter of 3 to 4 feet. The bark is close, sometimes shallowly fissured, and is usually of a grayish color.

The compound leaf is composed of 3 to 7 leaflets; very rarely 9 leaflets will be found. Being practically without individual stalks, the leaflets are attached by their bases to the common leaf-stalk of the leaf. The leaflets are smooth above, and smooth below except at the forking of the principal veins where a tuft of hairs may often be found. The tree flowers in May, and the fruits develop about October. The nut, which is the common, and usually bitter, pignut of the markets, is almost spherical, sometimes slightly compressed and is closely invested by a husk which splits very tardily, if at all. 
From New York to Florida and westward is the natural home of the pignut and it is common along the Hudson Valley.

\section{American Hornbeam}

CARPINUS CAROLINIANA

Of all the native trees of the Hudson Valley the wood of the hornbeam is undoubtedly the hardest and least easily worked. The tree is never more than 30 to 40 feet in height and the trunk is covered by a close-fitting, smooth, bluishgray bark. The tough, spreading branches, together with the trunk, are often fluted and have a characteristic sinewy appearance.

The oval or oblong, sharp-pointed leaf-blades are dull green in color, from 2 to 5 inches long, and coarsely toothed. On the upper side the veins are deeply impressed, thus making the leaf-blade distinctly roughened. The leaf-stalk is hairy and slender, and scarcely more than $1 / 2$ inch long.

There are two kinds of flowers on the hornbeam, those which subsequently develop into the fruits and those which do not. Both kinds are arranged in catkins, and bloom before the leaves expand, usually in April. The fruit is a small nut, scarcely more than $1 / 8$ inch in diameter, which is enveloped in a flat 3-lobed miniature leaf. Sometimes one or both of the lobes of this small leafy envelope may be wanting.

In moist bottom lands and often associated with the red maple, the hornbeam is in its natural element, although it is sometimes found in drier situations. The tree grows freely from Maine to Florida and westward, and is very common in the Hudson Valley.

\section{Hop Hornbeam}

OSTRYA VIRGINIANA

Although the wood of the hop hornbeam is almost as hard as the American hornbeam it is more easily worked, and is used for making mallets, handles of tools and other implements. Unlike the American hornbeam the bark of this tree is rough, and distinctly, but closely, fissured or roughened. 


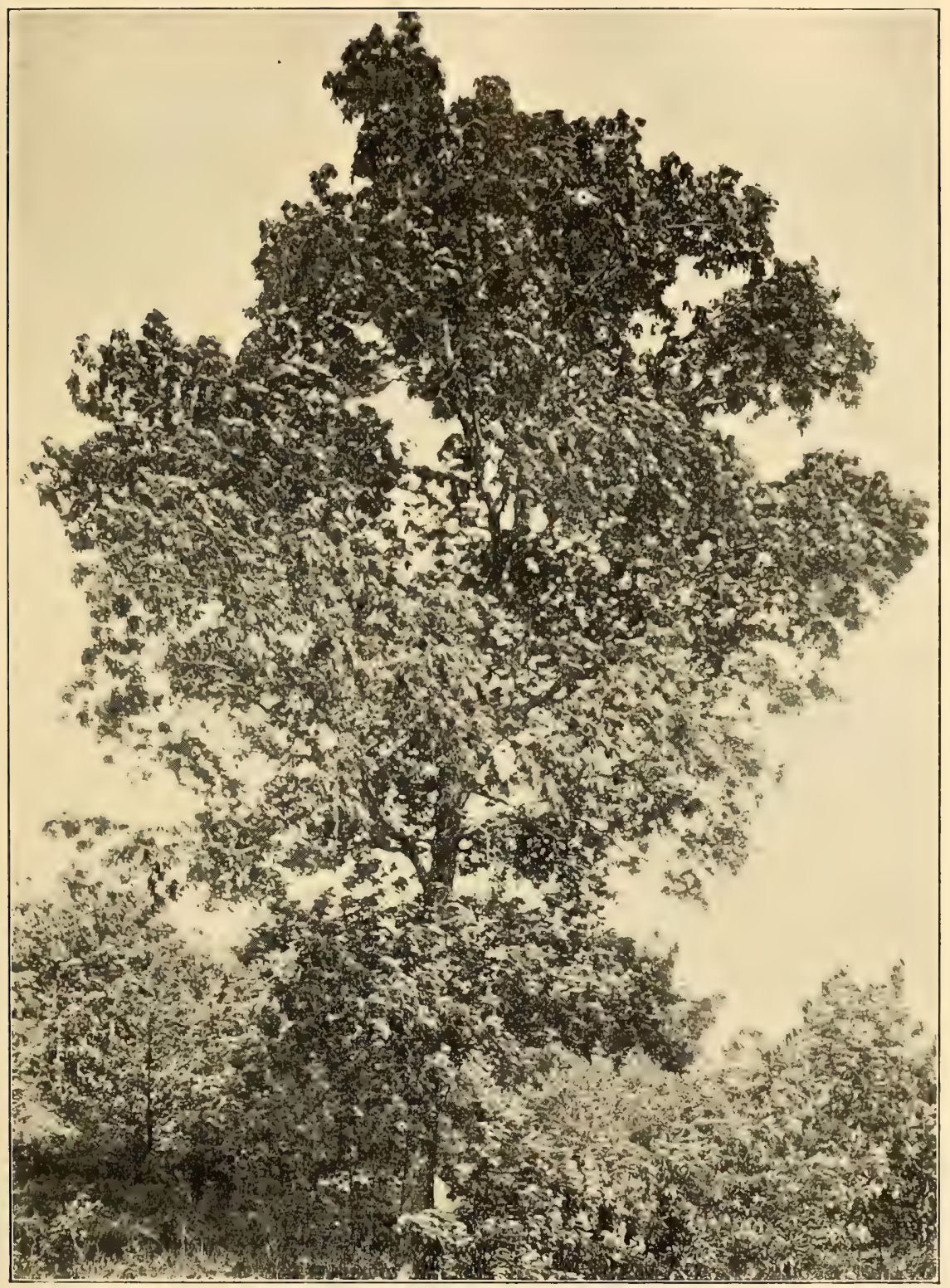

SMALL FRUITED HICKORY

New Baltimore, Greene County, N. Y. 

The tree rarely attains a height of 60 feet. The oblongpointed leaf-blades are coarsely toothed on the margin, and furnished with conspicuous tufts of hair on the under side at the juncture of the principal veins. A small tuft of hair tips the marginal teeth, when the leaves are very young.

Before the tree becomes covered with foliage, the catkinlike clusters of flowers bloom. The fruits follow, usually maturing during the summer. The fruit consists of a small nutlet completely enclosed by a bladder-like structure, and in this it differs from the American hornbeam in which the nutlet is surrounded by a small leaf-like wing.

This tree prefers dry gravelly slopes and ridges and is found growing wild from Cape Breton to Florida and westward. It is common in the upper Hudson region particularly near the country bordering the Catskills, becoming scarcer southward.

\section{Gray Birch}

Betula POPUlifolia

The brilliant white bark of the gray birch and paper birch serves at once to distinguish them from all the other Hudson Valley birches. In the gray birch, or white birch as it is often called, there are usually 2 to 5 trunks in a cluster. The tree rarely exceeds 40 feet in height.

The poplar-like leaves of the gray birch serve to distinguish it from the other white-barked birch. In the former the leaf-blades are delta-shaped and the tip of the blade runs out into a fine point. They are usually 2 to $3 \frac{1}{2}$ inches long, somewhat heart-shaped at the base, and the margins are coarsely toothed; these large teeth are themselves more finely toothed.

About the time the leaves unfold the catkin-clustered flowers bloom, followed subsequently, in the fertile flowers, by the fruits. These are a collection of scales, each scale enclosing a small winged seed.

Many common articles are made from the gray birch and it is extensively used in making charcoal. The tree occurs freely from Quebec to Pennsylvania and Ontario. It is common along the Hudson. 
Paper Birch

BETULA PAPYRIFERA

The familiar birch-bark canoe of the Indian was made from the impervious bark of this paper- or canoe-birch, as it is often called. As in the gray birch the bark is white, but often the lower part of the trunk of the paper birch becomes darker colored, particularly when the tree is old. In the Hudson Valley the tree is seldom over 80 feet in height.

The oval-shaped leaf-blades with the margin irregularly but not coarsely toothed, serve to distinguish this tree from the preceding. From $2-4$ inches is the usual length of the leaf-blade, and the top sometimes runs out into a fine point. In April and May the flowers open, either with or before the leaves. The sterile, non-fruiting catkins are usually clustered in twos or threes, but the fruit producing catkins are mostly solitary. The fruits are somewhat similar to those of the gray birch.

From Labrador to Alaska, southward to New Jersey and northern Montana is the natural range of the paper birch. It occurs sparingly southward and is known to grow along the Hudson Valley near the Catskills. (Plate I37.)

River Birch

BETULA NIGRA

From all the other birches of the Hudson Valley that have dark colored bark the river birch may be distinguished by its lack of an aromatic sap. The other dusky-barked birches all have the characteristic odor of birch-beer and other derivatives of their wintergreen-flavored sap. Under favorable conditions the river birch attains a height of 80 or 90 feet, and if growing in the open it develops into a freely branching, oblong-outlined tree. The reddish-brown bark is thick and irregularly segregated into small scales. The leafblades are sharp-pointed at the tip, oval in outline, and either wedge-shaped or blunt at the base. They are dark green and shining above and woolly on the veins beneath. In April and May the catkin-like flowers bloom, followed in June by the fruits. 


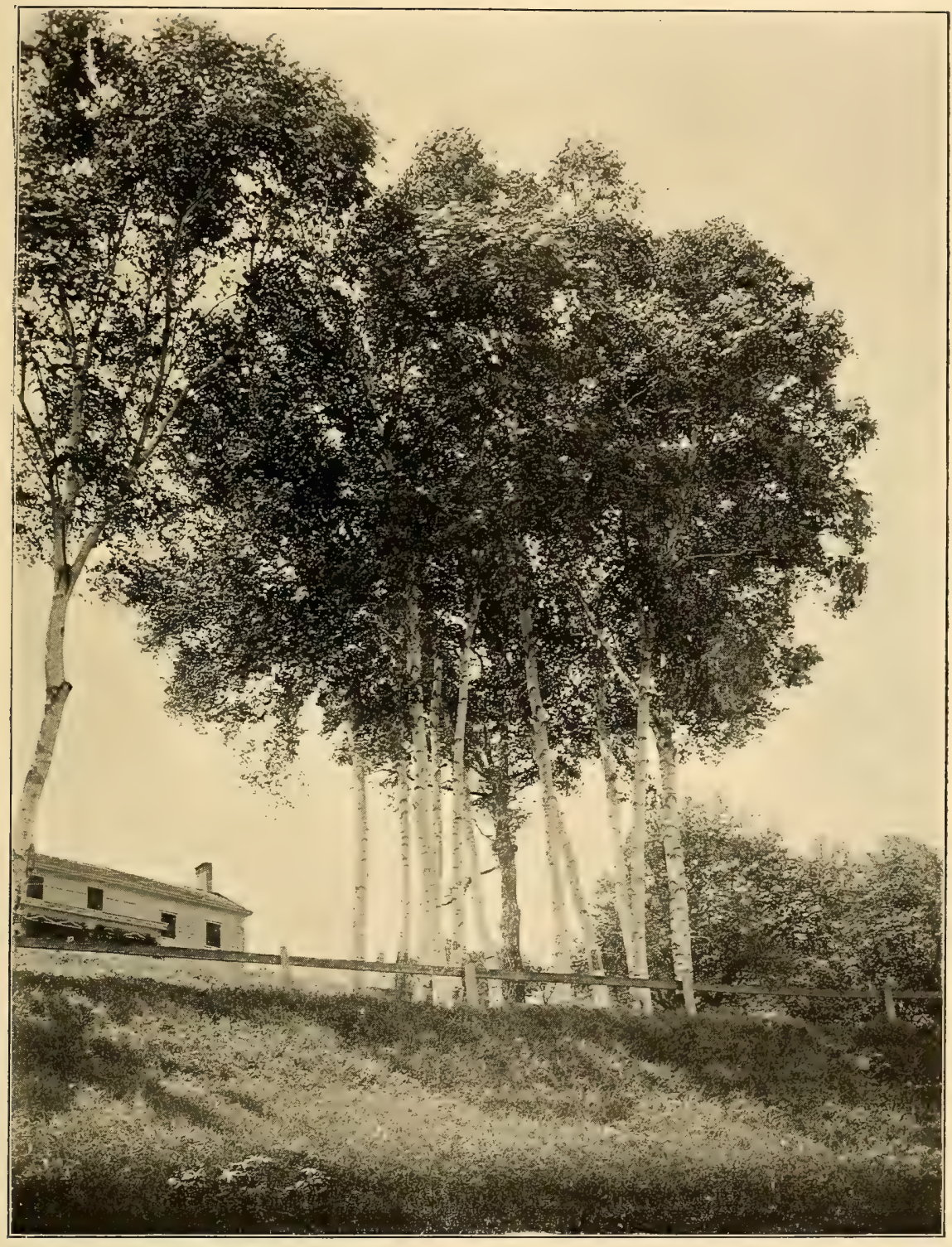

PAPER BIRCH

New Baltimore, Greene County, N. Y 

Various kinds of woodenware are manufactured from the wood of the river birch, and it is used for fuel. As its name indicates it prefers moist places along river banks, and it grows wild from Massachusetts to Georgia and westward. In the Hudson Valley it is known to grow near the Catskills, and southward to Staten Island.

\section{Cherry Birch}

Betula LENTA

Birch-beer, betul-oil and a flavoring extract, all of which are derived from the aromatic sap of the cherry birch, make it the best known of all the native birches. Under favorable conditions the tree often attains a height of 70 feet, and it is more or less symmetrically ovoid in outline. The nearly black bark of the tree has suggested the name of black birch, and it is known by this name in many places. The name sweet birch is derived from its aromatic sap. The ovaloblong leaf-blades are from $2 \mathrm{I} / 2$ to 5 inches long, sharppointed at the tip, and more or less heart-shaped at the base. The margins are sharply but not coarsely toothed.

Sometime before the leaves appear the tree is covered with its drooping and erect catkins of flowers. The pendulous non-fruiting kind are golden-brown, when mature, and the blending of these golden flowers with the reddish twigs produces beautiful color harmonies in the early spring. The erect, fertile catkins produce the fruit about two months after the flowers reach maturity. As in all the birches the seeds are prominently winged.

The cherry birch is confined to the region from New Brunswick to Georgia and Iowa. It is exceedingly common throughout the Hudson Valley.

\section{Yellow Birch}

Betula lutea

Although it has many characteristics in common with the cherry birch, the yellow birch can generally be identified by its yellowish or reddish-yellow bark. It is a tree sometimes as high as 90 feet and in the open it develops a broad rounded top. The bark of the branches and branchlets and 
sometimes of the trunk peels very readily and the curled up edges of these peelings give a very characteristic appearance to the whole tree.

Unlike the cherry birch, the oval-shaped leaves of this kind, are coarsely toothed and the larger teeth are themselves more finely toothed. It can be distinguished from the river birch by its stalkless catkins of flowers. In the latter sort the catkins are always stalked. The sterile catkins are usually found in clusters of from 2 to 4 . The fertile, or fruit-producing catkins are always solitary and usually fastened to the twig at its juncture with a leaf-stalk.

Agricultural implements, woodenware and furniture are all made from the wood of this tree. It grows wild from Newfoundland to North Carolina and westward, and is found along the upper Hudson.

\section{Southern Yellow Birch}

Betula Alleghanensis

This is related to both the cherry and the yellow birch. It is smaller than the latter and about the same size as the former. The bark on the trunk is sometimes peeled and sometimes merely fissured. It is usually of a reddish-yellow color.

The fertile catkins of this birch are scarcely more than $\mathrm{I} / 2$ inch long and more or less oval or globose-oval in outline. In the common yellow birch they are elliptic in outline and longer than those of this tree.

Lumbermen use the wood of this birch indiscriminately with that of the yellow birch and for like purposes. It grows in woodlands from Massachusetts to southern New York and westward. Trees of this birch are known to grow in the Highlands of the Hudson, and, when better known, it will doubtless be found elsewhere.

New York Alder

Alnus nOVEBORACENSIS

Nearly all the alders are typically shrubs, but specimens of this species are sometimes distinctly tree-like. So far as known the tree grows only on Long Island and Staten Island. 
The tree is some 25 feet high, having a trunk covered with a smooth brownish bark, and young brownish hairy twigs. The thin leaves are more or less oval in outline from $3 \mathrm{~T} / 2$ to 5 inches long, and acute at both ends, or sometimes they may be bluntish at the tip. The flowering catkins are of two kinds, sterile and fertile. The latter produce the fruits which cling to the branches throughout the following winter. The nut is winged.

Our native alders are of little economic importance.

American Beech

FAGUS GRANDIFOLIA

Its smooth, bluish-gray bark, silky-golden buds and its lustrous green leaves, which turn bright yellow in autumn, all make the beech one of the most distinctive and beautiful trees of the American continent.

It sometimes surpasses 100 feet in height and the trunk often exhibits a tendency to be fluted. The leaf-blades are oblong or oval-oblong, rough and with numerous veins, some of which terminate in the coarse marginal teeth. The flowers appear after the leaves unfold. Those which do not produce fruit are arranged in catkins and the fertile flowers are found usually two together on a short stalk. They have practically no petals. The fruit is a small nut completely surrounded by a prickly shell-like husk which splits and thus releases the seed.

The wood of the beech is much used for a variety of purposes and particularly in the manufacture of creosote. The kernel of the nut is sold in the Canadian market. The tree is confined to the eastern half of the continent and is common in the Hudson Valley.

The copper beech, a dark-leaved form of the European beech (Fagus sylvatica), is much planted for ornament, but it is not known to have established itself as a wild element in out native flora. 
American Chestnut

Castanea dentata

Most of the chestnut trees in the Hudson Valley are affected by a fungus disease that has failed to yield to the ordinary methods of fighting tree-diseases. If the disease keeps up its present activity, a few years hence will see the practical extinction of one of the largest and most useful trees of North America. In the open it often forms a roundtopped tree more than 90 feet across. The trunk is closely invested with a coarse, deeply fissured bark, and is often as much as Io feet in diameter. The lance-shaped or elliptic leaf-blades are sometimes as long as 8 inches and are furnished with coarse, sharp-pointed marginal teeth. Usually about the Fourth of July the tree is covered with its golden-brown catkins of flowers, making the tree a conspicuous feature of the landscape. The upper part of most of these catkins is sterile but the lower part of them subsequently develop into the well-known chestnut.

The chestnut is known to grow only east of the Mississippi and from central New York to Georgia. It is, or was, common throughout the Hudson Valley. The wood is of great economic importance and the bark is extensively used in the tanning of leather. (Plate I38.)

\section{Red Oak}

QUERCU'S RUBRA

Although the wood of the red oak is inferior to that of the white, it is largely used for interior decorating. The tree sometimes reaches a height of $\mathrm{I} 30$ feet with a trunk diameter of 5 feet. The stout spreading branches give the tree a broad round-topped outline. At first the young twigs are greenish becoming successively reddish and brown. The thin leaf-blades are green both sides, lobed about halfway. to the middle of the blade, and the divisions are always tipped with a strong bristle. As in all oaks the flowers are of two kinds, sterile and fertile. In the red oak the sterile are arranged in catkin-like clusters, and the fertile are usually solitary or in twos. The latter subsequently develop into the well-known acorn. In this oak the acorn is oval but with 


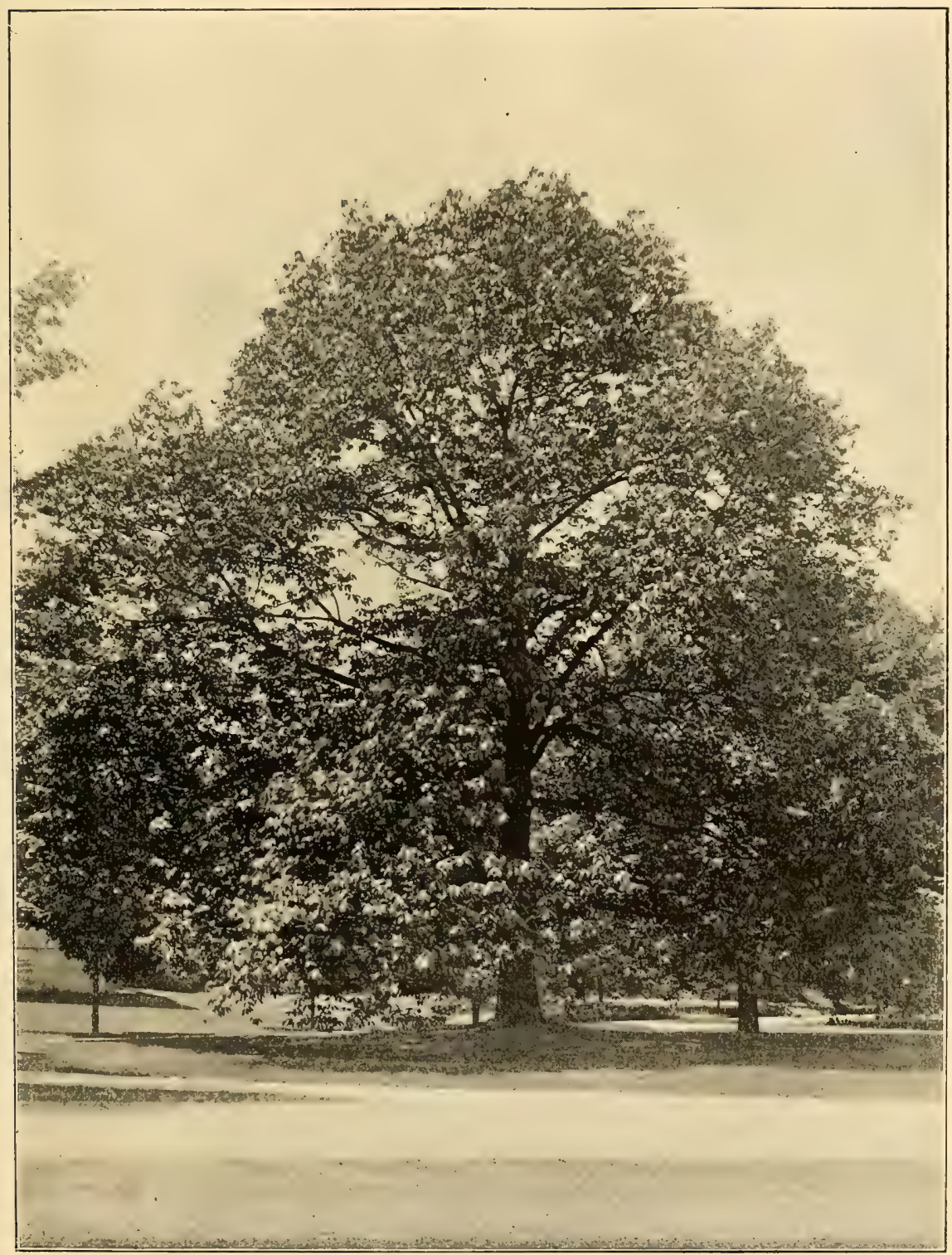

AMERICAN CHESTNUT

Vassar College Campus, Poughkeepsie, N. Y. 

a flat base, and usually $3 / 4$ to $I \frac{1}{4}$ inches long. The base is surrounded by a flat saucer-shaped cup, which is hairy on the inside.

The red oak is found growing wild from New Brunswick to Georgia and westward. It is common throughout the Hudson Valley.

\section{Swamp Oak}

QUERCUS PALUSTRIS

The coarse, rough wood of this oak make it undesirable for the fine work for which the wood of the red oak is used, and consequently it is used mostly for making shingles and clap-boards, and in rough construction work. On the whole it is a smaller tree, and has a more restricted distribution, although it is exceedingly common throughout the Hudson Valley.

The reddish, close bark is often scaly and split into small plates which are flattened against the trunk. The greenish young twigs turn reddish-brown when old. The blade of the leaf is oblong in general outline, but the bristle-tipped lobes divide it almost to the center. At its base the leafblade is narrowly or sometimes broadly wedge-shaped. The drooping lower branches, especially in older trees, are exceedingly characteristic.

The widely cultivated swamp oak has acorns decidedly different from those of the red oak. They are short-stalked, solitary or in small clusters, and nearly hemispherical; scarcely ever more than $1 / 2$ inch in diameter. The cup encloses only about one quarter of the acorn, and it is hairy on the inside. (Plate I39.)

\section{Black Oak}

QUERCUS VELUTINA

A conspicuous charactertistic of the black oak serves as a ready means of distinguishing it from all the other bristletipped sorts. The inner bark, easily disclosed by cutting in about an inch, is of a bright orange color. It is the titular head of all the bristle-tipped kinds, as they are often collectively known as the black oaks, and in this species the 
name is well taken for the bark is very dark in color, almost black.

The leaf-blade is ovate in general outline, but its lobes divide the blade almost halfway to the middle. From its wedge-shaped base to the bristle-tipped apex the blade is sometimes as long as Io inches, and the veins and sometimes the whole surface of the leaf-blade is hairy. When the leaves are about half unfolded the flowers appear, followed subsequently by the acorns. These are solitary or in pairs, often striped, or covered with fine reddish hairs. The cup encloses almost half the nearly globose nut.

For ordinary construction purposes the wood of the black oak is of very little value. The bark, however, is used as a yellow dye and in tanning leather. The tree grows freely from Maine to Florida and westward, and is common throughout the Hudson Valley. (Plate I40.)

Gray Oak

QUERCUS BOREALIS

This little-known oak occurs sparingly in the northern part of the Hudson Valley, and also in the mountains as far south as the Carolinas. It has some characteristics in common with the red and scarlet oaks; its acorns have flat saucershaped cups, similar to those of the red oak. One characteristic that may distinguish it from these trees is the fact that its leaves usually hang on longer in the autumn than do the leaves of the red and scarlet kinds. The tree is difficult to identify. The gray oak is alleged to grow further north than any other oak.

\section{Scarlet Oak}

Quercus coccinea

This tree takes its name from the brilliant scarlet coloring of its young leaves and the magnificent coloring of its autumnal foliage. When mature the leaves become bright green and shining. The tree often attains a height of 70 feet and a trunk diameter of 3 feet.

The broadly oval leaf-blades are divided almost to the middle by their lobes which are from 5 to 9 in number and 


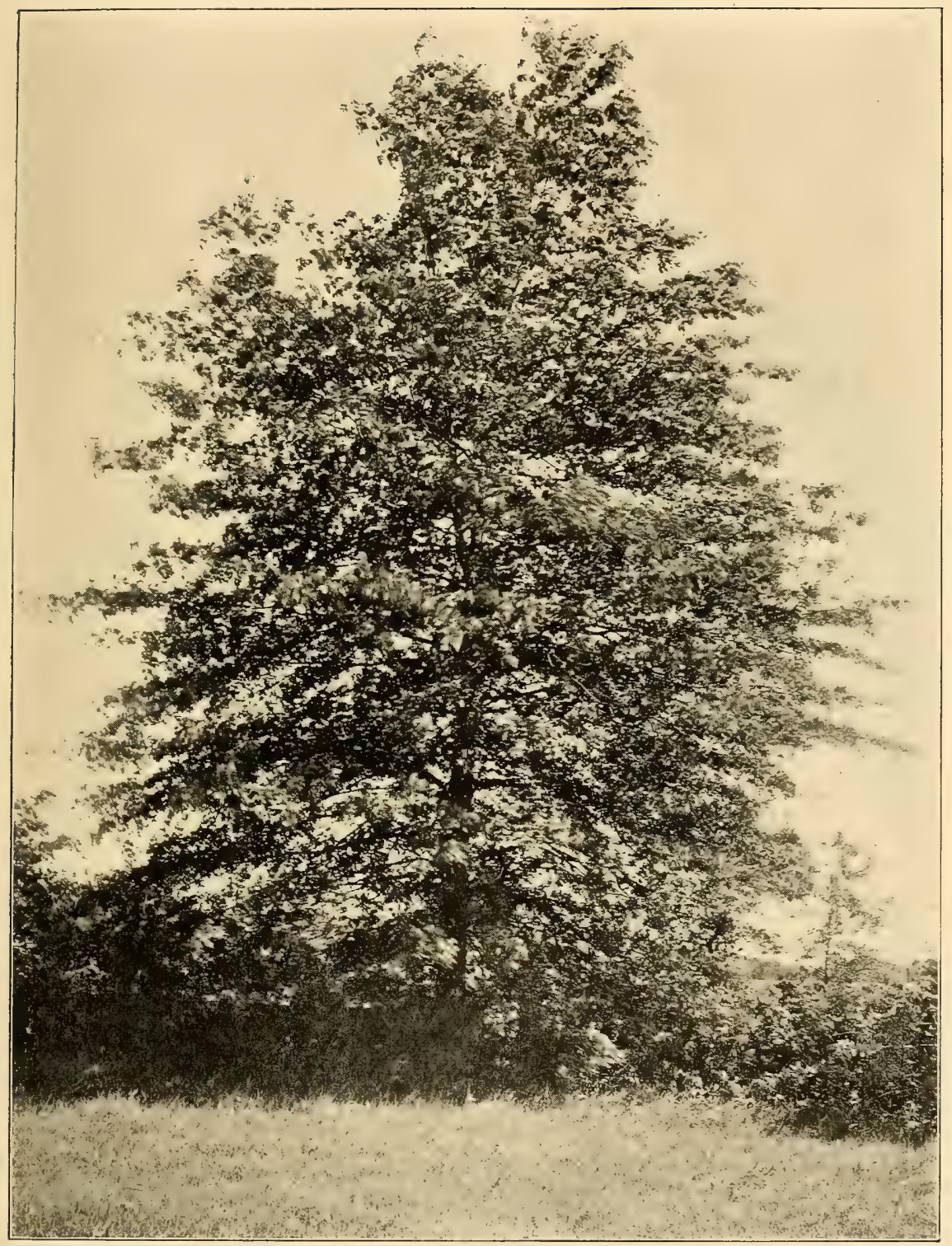

SWAMP OAK

New Baltimore, Greene County, N. Y. 

always bristle-tipped. From the blunt base to the acute, bristle-tipped apex the blade is usually from 5 to 8 inches long. On the under side of the blade they are paler than on the upper, and often furnished with tufts of rusty-colored hairs at the juncture of the more prominent veins. The flowers appear when the leaves are half unfolded, followed in the autumn of the second season by the acorns. These are practically stalkless, solitary or two in a cluster. The acorn is ovoid, from $1 / 2$ to $3 / 4$ of an inch in length, and enclosed for $1 / 3$ or $1 / 2$ of its lower part by the cup.

The scarlet oak grows best in dry sandy situations from northern New York to Georgia and westward to Iowa. In the Hudson Valley it is a fairly common tree. Its wood, which resembles that of the red oak, is used for much the same purposes, but is not so valuable.

\section{Black-Jack Oak}

QUERCUS MARILANDICA

From all the bristle-tipped oaks that have lobed leaves the black-jack oak can be easily distinguished by its peculiar leafblades. They are much broader above the middle than below it. In the Hudson Valley it is found only on Staten Island and adjacent Long Island and New Jersey. Further south it reaches a height of 40 feet.

The leaf-blades which are narrowed at the base, and conspicuously widened upward, are from 3 to 6 inches long. There are mostly three blunt, but bristle-tipped lobes, at the apex of the blade, which on the under side is usually covered with short brownish hairs. In April or May the flowers appear followed in the autumn of the second year by the acorns. These are hemispherical and from $1 / 2$ to $3 / 4$ inch long, and enclosed for their lower half by the thin cup.

The wood of the black-jack oak is little used except for fuel and in the manufacture of charcoal. The tree has much value for decorative planting, but is of very slow growth. 
The popular name willow oak is truly descriptive of this tree. It has the leaves of a willow and it is the only Hudson Valley bristle-tipped oak that is entirely without lobing in the leaves. The tree prefers rich bottom lands and its northern limit of growth is in the southern extremity of the Hudson Valley. On Staten Island there are some big trees of the willow oak.

The lance-shaped leaves closely resemble a typical willow leaf, and are from 2 to 5 inches from the sharp-pointed base to the bristle-tipped apex. In texture the leaf-blade is thick and leathery. Soon after the leaves unfold the flowers appear, followed in the second season by the acorns. These are mostly solitary, almost round and not more than $1 / 2$ inch in diameter. Only the base of the acorn is enclosed by the reddish-brown cup, which is hairy on the inside.

The wood is used sparingly in the manufacture of wagons, but the tree is valuable for ornamental planting from Philadelphia southward.

\section{Yellow Oak}

Quercus MuhlenbergiI

The chestnut oak is also one of the names used for this tree and it is well chosen for the leaf is something like the chestnut leaf. In the most favorable situation the tree may be as high as 160 feet, but in the Hudson Valley it is never so tall as this. The bark is light brown and the twigs, at first green, become dark brown in age. The oblong, lanceshaped leaf-blades are from 4 to 8 inches long, sharp-pointed at both ends, and with several small marginal lobes or roundish teeth. The lobes and tip of the blade are not bristle-tipped. In the spring, appearing with the leaves, the flowers come out, followed in the succeeding autumn by the acorns. These are practically stalkless, solitary or two in a cluster. The nut is ovoid, $1 / 2$ to $3 / 4$ inch long and its lower half enclosed by the woolly cup.

The wood of the yellow oak is very hard, not easily seasoned, and is mostly used for rough construction work, 


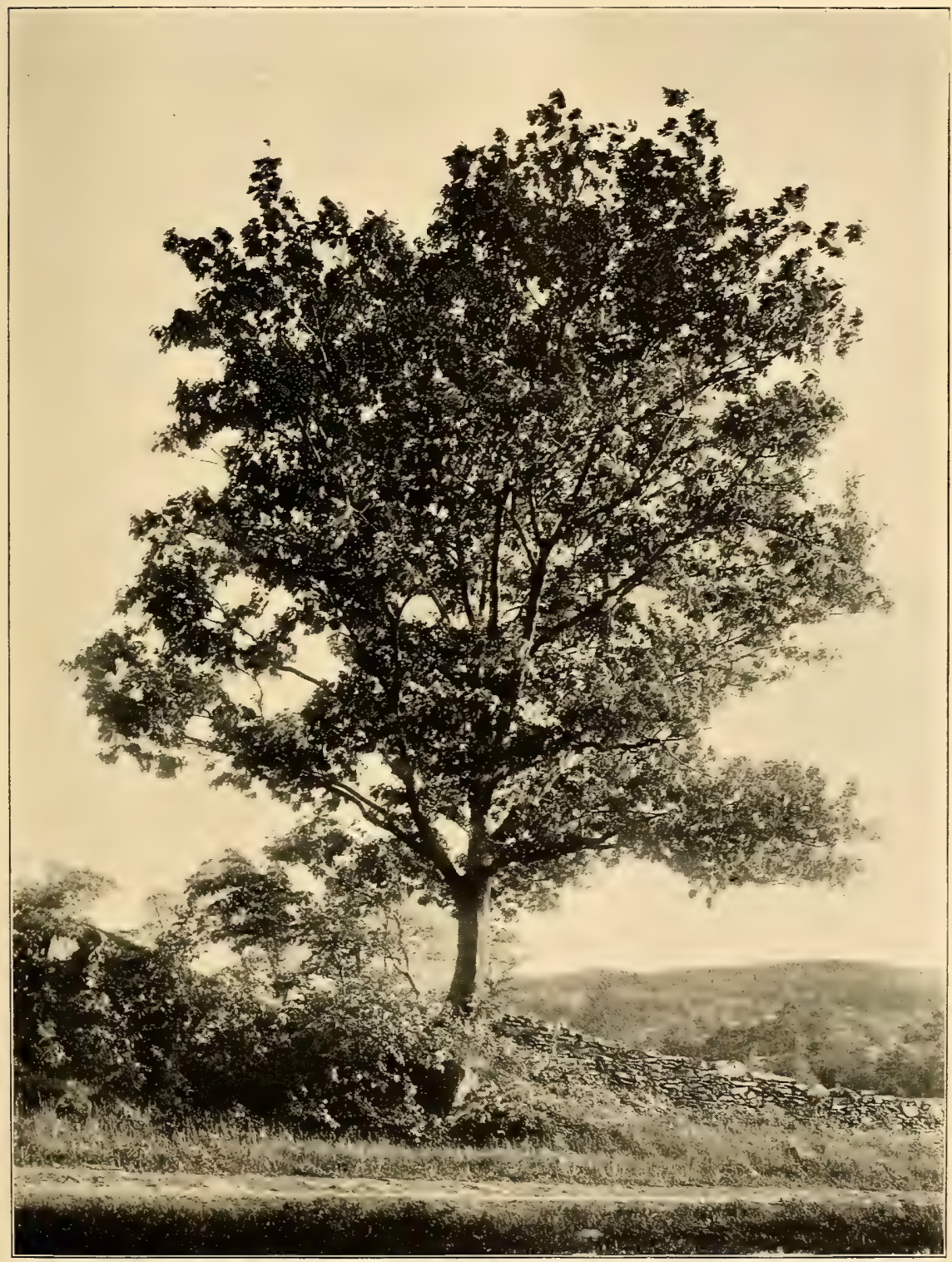

BLACK OAK

New Baltimore, Greene County, N. Y. 

such as railroad ties and fencing. The tree grows naturally from New York to Alabama and westward. It is common in the Hudson Valley particularly in the Highlands.

\section{Alexander's Oak}

QUERCUS AlEXANDERI

This oak is rare in the Hudson Valley. Trees have been observed at West Point and Hyde Park, but it is doubtful if it is found south of these points. It is otherwise known from Vermont to Michigan and Iowa. From the yellow oak, to which it is botanically allied, it can be distinguished by its leaf-blades which are broadest above the middle, and have shallow lobes or teeth. The cup of its acorn encloses only the base of the nut, in contrast to the yellow oak where the nut is half enveloped by the cup; its bark is somewhat flaky.

\section{Rock Chestnut Oak}

Quercus Prinus

As in the two preceding kinds this oak has leaves that strongly resemble the leaf of a chestnut. The trunk often becomes forked a short distance above the ground and the tree is often as high as 70 feet. The exceedingly coarse deeply-fissured bark is used in tanning leather. The oblong or lance-shaped leaves are from 6 to 8 inches from the narrow base to the equally narrowed apex. Neither the tip of the blade nor the numerous, rounded marginal teeth are bristletipped. When the leaves are about one third unfolded the flowers appear, followed subsequently by the acorns. From the other chestnut oaks this sort differs in having its acorns at the end of a stout stalk. The nut is ovoid or oblong and from $\mathrm{I}-\mathrm{I} \mathrm{I} / 2$ inches long; its lower half is enclosed by the hairy cup.

The hard, close-grained wood is hard to cure and is used mostly for railroad ties, fencing and so forth. The tree is confined to a wide belt ranging from central New York to Georgia, and as its name implies prefers rocky situations; it is common in the Hudson Valley. 


\section{( II 8 )}

Swamp White Oak

QUERCUS BICOLOR

This oak often attains a height of 90 feet in the forest but isolated specimens are usually lower and broader. The tortuous branches and trunk are invested by a red-brown, scaly bark, which on the trunk is deeply furrowed with confluent fissures.

The leaf-blades are lobed, but not deeply so, and in general outline the blade is broadest above the middle. Neither the lobes nor the apex of the blade are bristle-tipped. The leaf-blades are green above and more or less woolly and pale beneath. In April or May the flowers appear followed in the succeeding autumn by the fruit. The nut is slenderstalked, ovoid, about $3 / 4$ of an inch long and its lower half is immersed in the woolly cup.

The tree prefers moist places and is found from Quebec to Georgia and westward. Its wood is sold indiscriminately by lumbermen for the same purpose as white oak and it is exceedingly valuable.

\section{Bur Oak}

QUERCUS MACROCARPA

In some situations this tree attains a height of I 70 feet, but it never becomes as tall as this in the Hudson Valley where it is local and found only in the northern part. The brown or reddish bark is deeply fissured and split into irregular plates.

The upper half of the leaf-blade is broader than the lower half and divided almost to the middle by the lobes. The terminal lobes are longer than the lateral ones, and are coarsely blunt-toothed. Neither the apex, lobes nor teeth are bristle-tipped. The upper surface of the leaf-blade is smooth and green, the lower grayish and hairy. According to the latitude the flowers appear from March to June, in the Hudson Valley early in May. The stalkless fruits mature the same autumn, singly or in clusters of 2 or 3 . The nut is almost round or sometimes oblong, and varies from $1 / 2$ to 2 inches long according to latitude. It is about half immersed in a cup which is conspicuously fringed at the 


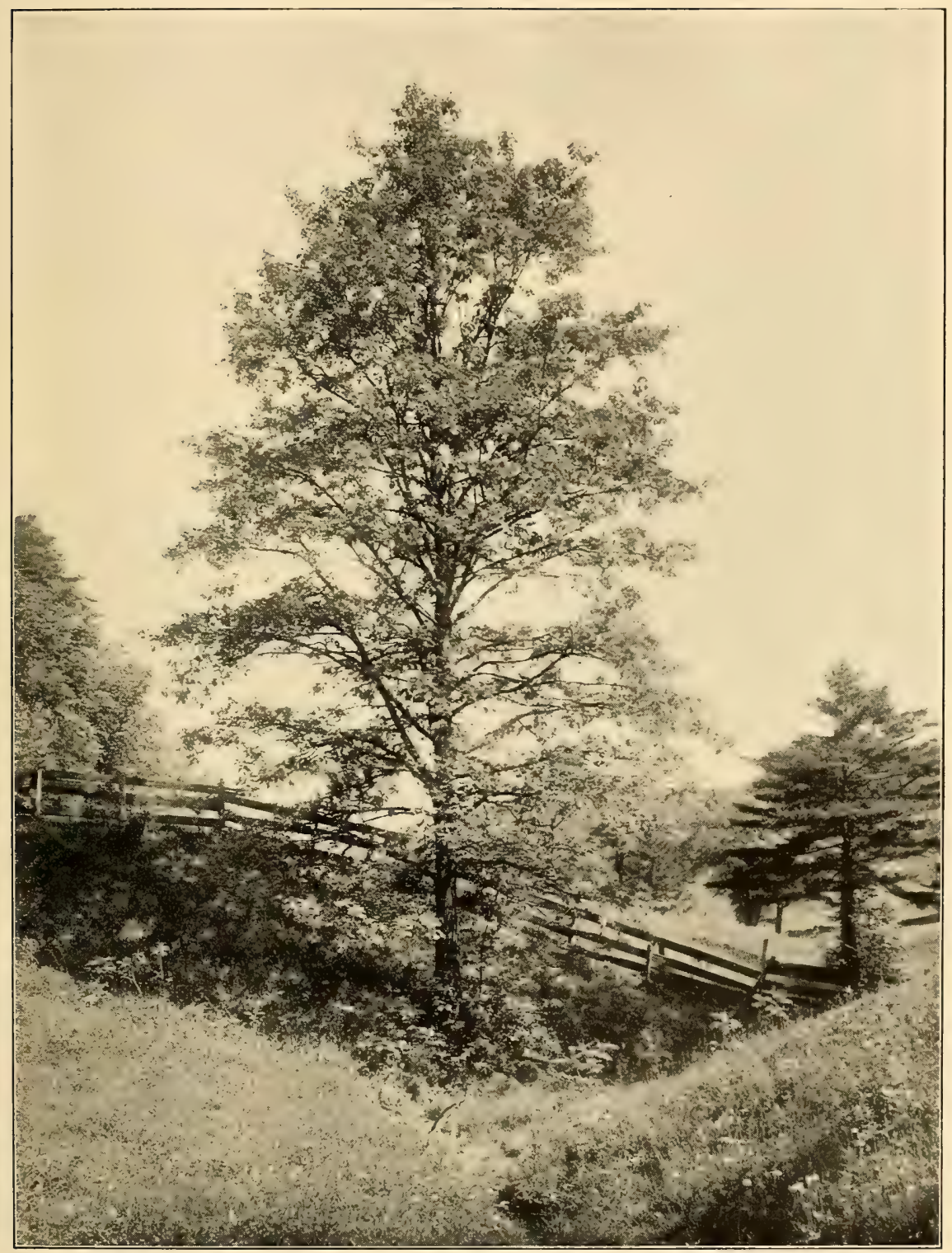

BUR OAK

New Baltimore, Greene County, N. Y. 

upper edge. This fringe or burr on the cup gives the tree its name and serves to distinguish it from all the other oaks in the Hudson Valley.

Commercially the tree is very important, its wood being used for a variety of purposes. It occurs from New Brunswick along the mountains to Tennessee and westward, where it reaches its greatest development. (Plate I4I.)

\section{Post Oak}

Quercus STEllata

The post oak reaches its northernmost limit on Staten Island and the adjacent territory in New Jersey and Long Island. It does not attain its full dimensions in this region and never reaches 100 feet in height, a stature credited to it in southern Ohio. The flat-ridged bark is coarse, and grayish-brown in color.

A peculiarity of its foliage furnishes the reason for the name stellata, meaning star or star-like. The leaves are closely clustered, which, with their deep lobing, give the leaf clusters enough resemblance to a star to make the name appropriate. The divisions of the leaf-blade extend almost to the middle, and a striking feature of the lobing is that the middle lobe is longer than those above and below it. The acorn which is often as long as I inch is ovoid in outline, and the nut is usually half enclosed by the woolly cup.

The wood of the post oak is resistant to rotting agencies when under ground and is much used for work of this nature, and in cooperage.

\section{White Oak}

QUERCUS ALBA

From a commercial point of view this is probably the most valuable tree of the American continent. Its wide spreading branches and majestic trunk very actively suggest the idea of great architectural strength. The tree is frequently as high as 150 feet, but in the open usually shorter than this and correspondingly more widely spreading. It takes its name from the shallowly fissured light gray or whitish bark.

The deeply lobed leaf-blades are not bristle-tipped, and as 
in the post oak there is a tendency for the middle lobe to be longer than the lobes above and below it. The base of the blade is sharply wedge-shaped. When the leaves are about one third unfolded the flowers appear, followed in the same autumn by the usually stalkless acorns. The nut is ovoid or oblong and about $3 / 4$ of an inch long, covered only for its lower fourth by the woolly cup.

The tree is very common within its area of distribution, which extends from Quebec to Florida and westward. It is well represented in the Hudson Valley by many magnificent specimens.

\section{American Elm}

ULMUS AMERICANA

The American or white elm is the largest and most widely dispersed of our native elms. The well-known habit of branching gives the tree a distinctive and beautiful outline, which is particularly attractive in winter. The branches are without corky ridges, which distinguishes another native elm, and are usually reddish-brown. The leaf-blades are smoothish above, oval in outline, abruptly pointed at the apex, and from 2 to 5 inches long. The base of the blade is usually inequilateral, and the leaf margins are conspicuously toothed.

Some time before the leaves unfold the flowers appear. As the word is usually understood they are without petals. In early summer the little clusters of fruits mature. Individual fruits consist of a seed with a wing surrounding and closely investing it. In the American elm the seed-wing is smooth on its face but conspicuously hairy around its edges.

In New England the elm has been planted for decorative purposes more extensively than any other tree. It grows wild from Quebec to Florida and westward, and is very common in the Hudson Valley. Besides its decorative value the American elm is prized for its valuable wood which is much used for making ships, floors, and so forth. (Plate 142.)

Slippery Elm

ULMUS FULVA

The highly mucilaginous inner bark of this tree has given it its common name of slippery elm. It is not so tall as 


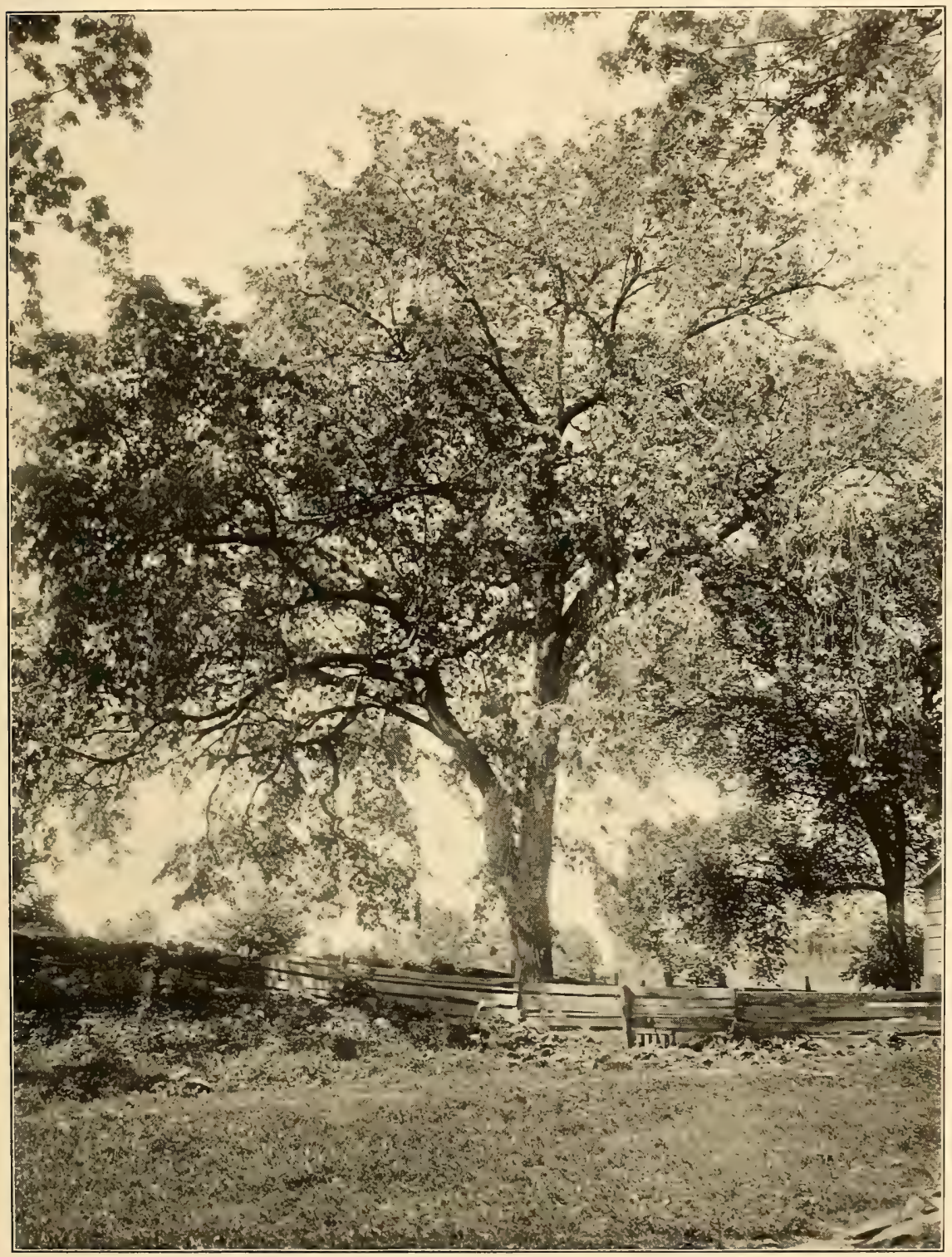

AMERICAN ELM

New Baltimore, Greene County, N. Y. 

the American elm, and more local and rare in its distribution. The outer bark is darker and more deeply fissured.

In general outline the leaves much resemble those of the American elm but they are larger, more conspicuously toothed on the margins, and very prominently roughened on the upper surface. Its flowers are very similar to those of the better known tree but the fruits have one characteristic that is strikingly different from the preceding kind. The wing of the seed is quite smooth on its edges, and on the face it is hairy only immediately over the seed.

The slippery elm is found from Maine to Georgia and westward. It is fairly common along the Hudson, especially northward. The slippery elm lozenge is made from the precipitation of the mucilage which the tree secretes so extensively in its inner bark. The wood is also valuable for construction purposes.

Cork Elm

Ulmus Thomasi

This is the least known and most locally distributed native elm. It attains a height of 80 or 90 feet in favorable situations. The trunk is stout, and clothed by the thick fissured bark. The lower branches are often conspicuously drooping, and the young branches have prominent corky wings along the sides.

The oval-outlined leaf-blades are sharp-pointed at the tip, and rounded at the nearly equilateral base. The marginal teeth are prominent, incurved and the large teeth are themselves toothed. Before the leaves unfold the flowers appear, followed in early summer by the fruits. These differ from both the American and slippery elm in having the seed-wing hairy on its margin and also its entire surface.

Railroad ties, bridges, and agricultural implements are all made from the wood of this tree. It grows wild from Quebec and Ontario to northern New York, Tennessee and westward. In the Hudson Valley it is rare, and only definitely known in the northern part.

The English elm (Ulmus campestris) is widely planted 
for ornament but is not known to have established itself as a wild element in our native flora.

\section{Hackberry}

Celtis occidentalis

In the Hudson Valley this is not a common tree and frequently escapes notice as there it never attains its full dimensions; but further south and west it becomes 60 feet in height. The rough, often corky-winged bark is gray-brown and becomes scaly when old. The smooth leaf-blades are 2 to 4 inches long, oval in outline, with a fine-pointed tip, and a rounded or heart-shaped, inequilateral base. Sometimes there are marginal teeth and sometimes the margins are quite smooth. Just as the leaves unfold the small greenish flowers come out, usually at the base of a leaf-stalk. They subsequently develop into a fruit which is berry-like, but has a hard bony stone. The outside skin of the fruit may be red, or orange, but more frequently black.

In the Hudson Valley the hackberry is of little commercial importance as its scarcity precludes regular supply. Geographically the tree has a wide range, extending from the Atlantic coast to the Great Plains.

\section{Rough-leaved Hackberry}

Celtis CRAssifolia

The rough-leaved hackberry is more rare than the common kind. Very few trees are known to occur in the Hudson Valley, but one good specimen occurs along the east bank of the river at the southern end of the Highlands. The tree may be distinguished from the common hackberry by its rough leaf-surface. In other respects it is closely related to the preceding species.

\section{Red Mulberry}

MORUS RUBRA

This is the only native mulberry that grows in the Hudson Valley. The Old World white mulberry, so much grown for the silkworm industry, occurs only as an occasional escape from cultivation. The native species is a tree from 60 to 80 feet in height, with a trunk diameter of 3 to 4 feet. The long-fissured bark often splits off in plates. 
For variety of leaf-shapes it is doubtful if many known trees equal the red mulberry. When young the leaves are often deeply lobed, sometimes one-sidedly so, and sometimes they are without lobes. The mature leaf-blade is usually oval in outline, with a square or heart-shaped base and an acute-tipped apex. The margins are prominently toothed. The catkin-clustered flowers come out with the leaves, the fertile clusters followed in early summer by the juicy fruits. These are really a conglomeration of many fruit-units all going to form what is popularly termed the fruit.

The wood has some commercial value, and the tree deserves wide planting for its decorative value. It is found from central New York to the Gulf of Mexico and westward. In the Hudson Valley it is local and rare in the southerly portion, and probably wanting northward.

\section{Sweet Bay}

MAgNolia VIRGINIANA

In the southern states this often becomes a tree exceeding 50 feet in height, but in the Hudson Valley, it is not known to be more than a shrub or a shrub-like tree. On Staten Island and in adjacent New Jersey it grows in swamps.

The plant may be identified by its leathery lance-shaped or oval leaf-blades which are conspicuously white, silky-hairy, on the under side. Beautiful white, fragrant flowers appear in June and the conspicuous red fruits later in the summer.

\section{Tulip Tree}

LIRIODENDRON TULIPIFERA

One of the most attractive trees for decorative planting in the eastern states is the tulip tree. Its giant columnar trunk is often free of branches for 50 or 60 feet but it may have branches lower than this in some specimens. The tree frequently exceeds $\mathrm{I}_{5} \mathrm{O}$ feet in height and is usually broadly oblong in outline.

The characteristic leaves give a striking distinctiveness to the tree. They are broadly heart-shaped at the base, and conspicuously notched at the apex; and the lobes are at first shallowly and subsequently deeply divided. The blade is 
shining and gives to the foliage its lustrous green color. In May or June the beautiful flowers appear. They are always solitary at the ends of young twigs, and their tulip-like form has given the tree its popular name. The orange-yellow or greenish-yellow color of the flowers is very conspicuous, and, as the flowers frequently exceed $\mathrm{I} / 2$ inches in depth, the tree is very attractive in full bloom. The cone-like fruits develop the same autumn and shed their seeds after the tree has become bare.

It is often known as the yellow poplar, saddle-leaf or white-wood, and under the latter name it is much used for carpentry. The native home of the tulip tree is from Massachuetts to Florida and westward. In the upper Hudson Valley it is rare and it is probable that most of the trees above Poughkeepsie are cultivated or derivatives of plants once cultivated. South of this point it is common. (Plate I43.)

\section{Sassafras Tree}

SASSAFras SASSAFRAS

In central New York and Massachusetts which are the northern limits of the sassafras it is often a mere shrub but occasional trees are seen and they frequently exceed 30 to 40 feet in height. Further south the tree attains a height of 80 or 90 feet. Even on young trees the bark is very coarselyfissured and brownish in color.

There is a bewildering variety of leaf shape on most sassafras trees. On the same twig one often finds unlobed oval-shaped leaf-blades, intermixed with leaves lobed on one or both sides. When fully mature they usually have two prominent lateral lobes and a terminal one. In all forms the base of the blade is more or less wedge-shaped. At the ends of the twigs, and appearing with or before the leaves, the yellow-green flowers are clustered. Each cluster is at first enclosed by a green bud. The fruits are almost round, more or less fleshy and scarcely more than $1 / 2$ inch in diameter. They ripen in August or September.

Oil-of-sassafras is extracted from the roots and bark, and 


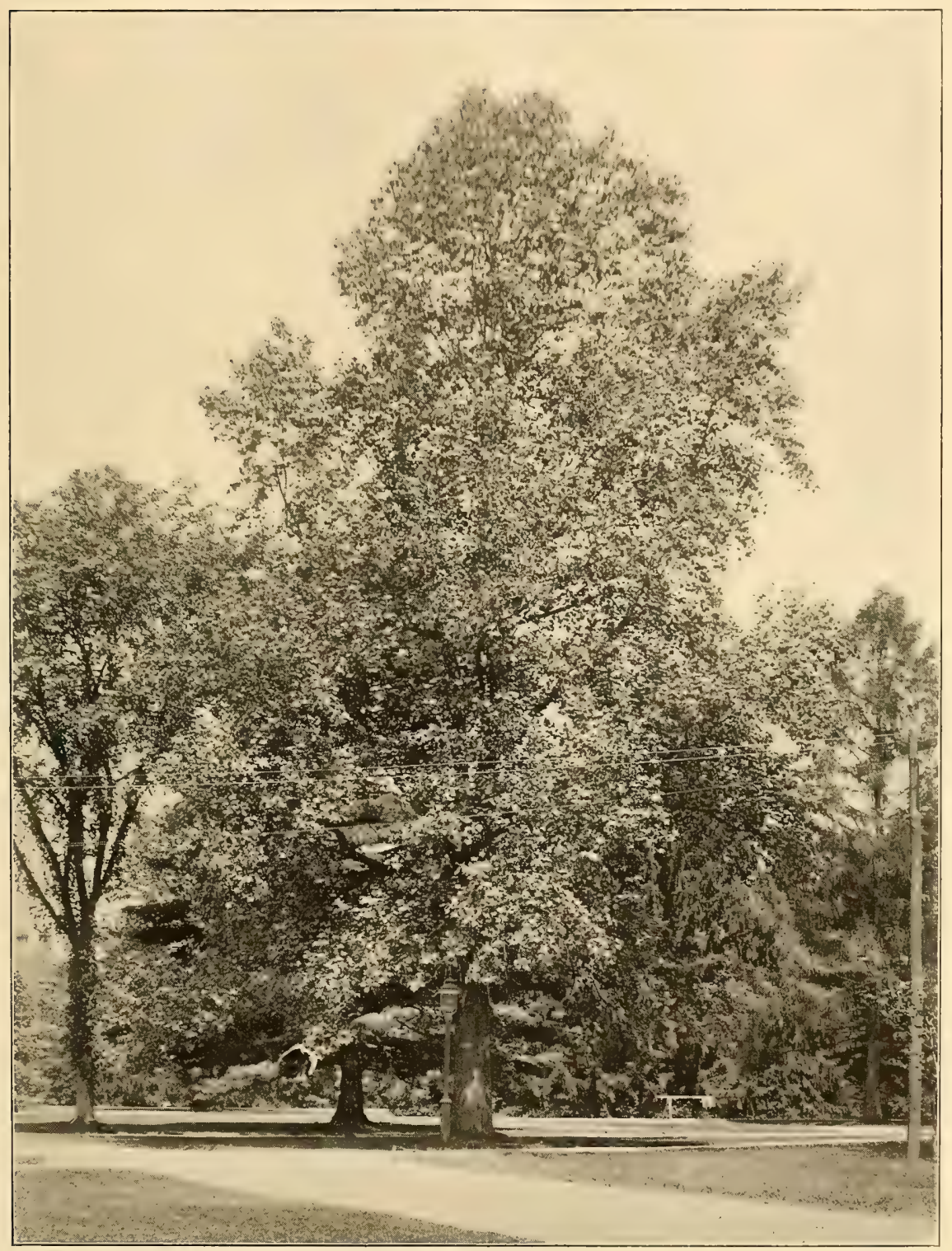

TULIP TREE

Vassar College Campus, Poughkeepsie, N. Y. 

medicinal properties are credited to the bark of the root and the pith of the twigs. The wood is used in making pails and buckets, and for fence posts. It is common along the Hudson but most of the specimens are more shrubby than treelike.

Sweet Gum

Lrquidambar Styraciflua

Of all the trees included in this list it is doubtful if one of them surpasses in brilliancy of coloring the gorgeous autumnal tints of the sweet gum. In the Hudson Valley it becomes a tree Ioo feet high or more. Its branches are ascending, and when very young covered with dense brown hairs, which subsequently fall away.

The characteristic star-shaped leaf-blades have a conspicuous tuft of hairs at their base on the under side of the blade. The lobes of the leaf are all pointed and the terminal and two upper lobes are conspicuously larger than the lower lobes. Both the fertile and infertile flowers of the sweet gum are arranged in globular little heads. The infertile heads are clustered on slender stalks which are all joined to a main flower-stalk, while the fruit-producing flower-heads are solitary on a short stalk arising at the base of the infertile flowerstalks. The fruit matures in the autumn and is about $I \frac{I}{2}$ inches in diameter; its whole surface is crowded with a collection of stout recurved prickles.

The wood of the sweet gum is used for a great variety of purposes, street paving-blocks being one of them. It grows naturally from Connecticut to Florida and westward. It is common in the lower Hudson Valley but rare or perhaps wanting north of the Highlands. (Plate I44.)

\section{Button Wood}

Platanus occidentalis

Peter Kalm, a discriminating historian and traveller, writing in 1749 , relates that in the northern part of New York City, large groves of the button wood flourished. To-day it is a common tree throughout the Hudson Valley and is found very generally distributed in the eastern states.

The peeling of the outer bark and consequent exposure of 
large patches of the light gray inner bark is a conspicuous feature of this tree. The young branches, leaf-stalks and leaf-blades are all covered with a coating of white wool which falls off later. The broadly oval leaf-blades are coarsely-toothed or lobed, heart-shaped at the base, and sharp-pointed at the tip. Usually they are from 4 to 7 inches long, but vigorous young leaves are often twice this size. The little ball-like clusters of flowers have given the tree the frequently used name of button-ball. Usually the sterile and fertile flowers are arranged in separate flowerballs but sometimes a single ball may contain a mixture of both kinds of flowers. The fruit is scarcely more than I inch in diameter, ball-like, and yellow-brown in color.

The wood of the button wood, or sycamore as it is often called, is used for making tobacco boxes, ox-yokes and other articles and also for interior finishing. (Plate 145.)

\section{American Mountain Ash}

SORBUS AMERICANA

Throughout most of its range this plant is more shrub-like than tree-like, but in the far north it often attains a height of 25 feet.

The leaves are compound, that is, composed of from I 2 to I 8 lance-shaped leaflets all fastened to a common leafstalk. Each leaflet is acute at both ends and sharply toothed. The flowers are scarcely more than $1 / 8$ inch in diameter but some hundreds of them are arranged in a broad flat-topped cluster that is frequently 3 or 4 inches across. In the fall the tree is conspicuous with its brilliant scarlet berries.

The tree is too small and weak-wooded in the Hudson Valley to be of any commercial importance, but its brilliant autumnal coloring and its clusters of white flowers make it a splendid tree for decorative planting.

\section{American Crab Apple}

Malus CORONARIA

The only native apple tree to grow wild in the Hudson Valley is this crab apple. All the ordinary apple trees are derived from the European apple, and in some places this 


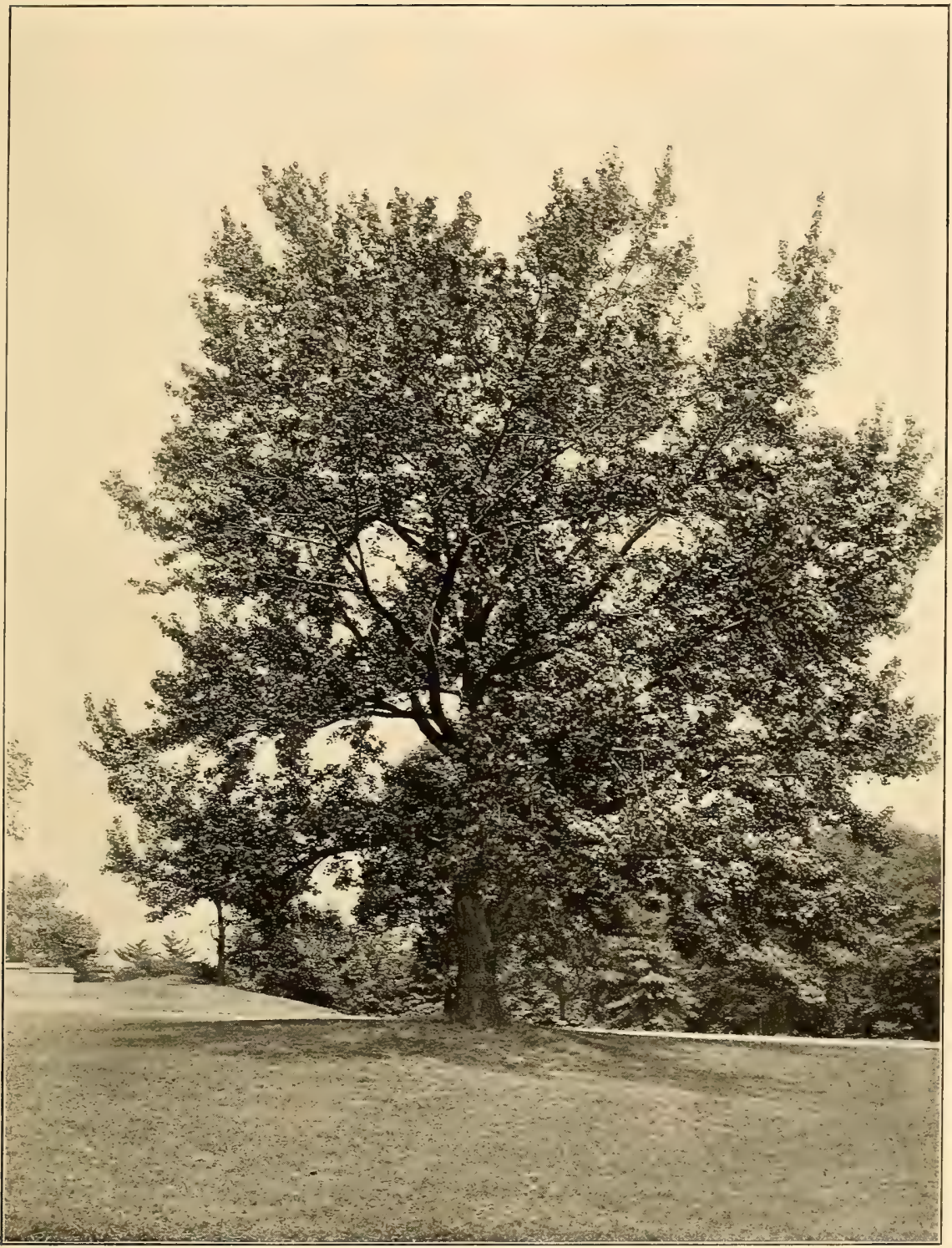

SWEET GLM

New York Botanical Garden 

has escaped from cultivation and is now practically wild.

The crab apple is a tree sometimes as high as 25 feet, and its stout spreading branches often form a round-topped tree that is almost as wide as this. The oval-oblong leaf-blades are mostly rounded at the base and rounded or pointed at the tip. The marginal teeth are numerous and sharp. The flowers are usually clustered and make a magnificent showing in the early spring. The fine whitish or rose-colored petals, exhaling a delicate fragrance, are the most conspicuous feature of the flowers. In mid-summer the crab apples are ripe. They are usually about $1 / 2$ inch in diameter, fragrant and greenish-yellow in color.

The natural range of the tree is from Ontario south to the District of Columbia and westward. It is evidently rare in the Hudson Valley but grows in northern New Jersey. A few tool handles and domestic articles are made from its wood.

\section{Serviceberry}

AMELANCHIER CANADENSIS

The illustration gives a very fair idea of the shape of the serviceberry. The tree is seldom more than 40 feet high and often forms a symmetrical round crown. The shallowly fissured bark is dark reddish-brown and the twigs are the same color when old, and quite smooth. The leaf-stalks and young leaves are usually slightly hairy but become smooth when mature, except that the under side of the leafblades are sometimes persistently hairy. The leaf-blades are from $2 \mathrm{~T} / 2$ to 4 inches long, oblong or oval-oblong in outline, and shallowly heart-shaped at the base. On the margins the leaves are somewhat coarsely toothed.

When the leaves are about one third grown the white flowers cover the tree. They are clustered and often the clusters droop. The fine white petals are arranged not unlike a star, and they are blunt at the tip and narrowed towards the middle of the flower. About July or August the reddish-purple fruits ripen. There are from 4 to Io seeds in each fruit, which is not more than $5 / 8$ inch in diameter. 
Tool handles and machinery are sometimes made from the wood of the serviceberry and the fruit is often eaten. The tree grows wild from New Brunswick to Florida and is common in the Hudson Valley region. (Plate I46.)

\section{Swamp Serviceberry}

AMELANCHIER INTERMEdia

The swamp serviceberry is a smaller tree than the preceding and it has other distinguishing characteristics. It rarely forms such a symmetrical tree as the common serviceberry, and is usually spindly or scraggy when growing in a crowded forest; it may often be found with several trunks arising from the same point, and is more commonly a shrub than a tree.

When the leaves and twigs are very young they are covered with a growth of dense white wool, but most of this wool is shed as they grow older. In outline the leaf-blades are elliptic or oblong, and they are very rarely heart-shaped at the base. The margins are toothed except towards the lower end of the leaf-blade where the teeth are often wanting. Before the leaves are fully expanded the flowers come out. They are very similar to those of the common serviceberry. The fruits of this sort are somewhat larger than the preceding, and dark purple-black when ripe.

The swamp serviceberry is of little economic importance. It has a similar range to that of the serviceberry and is very common all along the Hudson.

Cock-spur Thorn

Crataegus Crus-galli

Most of the thorns are mere shrubs but a few are small trees. They are armed with curved or straight prickles. The cock-spur thorn is often a tree 20 feet high or more with smooth, spreading branches. The leaf-blades are elliptic or sometimes wider above the middle, dark green and leathery when old. The leaf-margins are conspicuously toothed at the apex but smooth at the base. In early summer the tree is covered with a profusion of white flowers. These are usually arranged in little clusters of 7 or 8 . In 


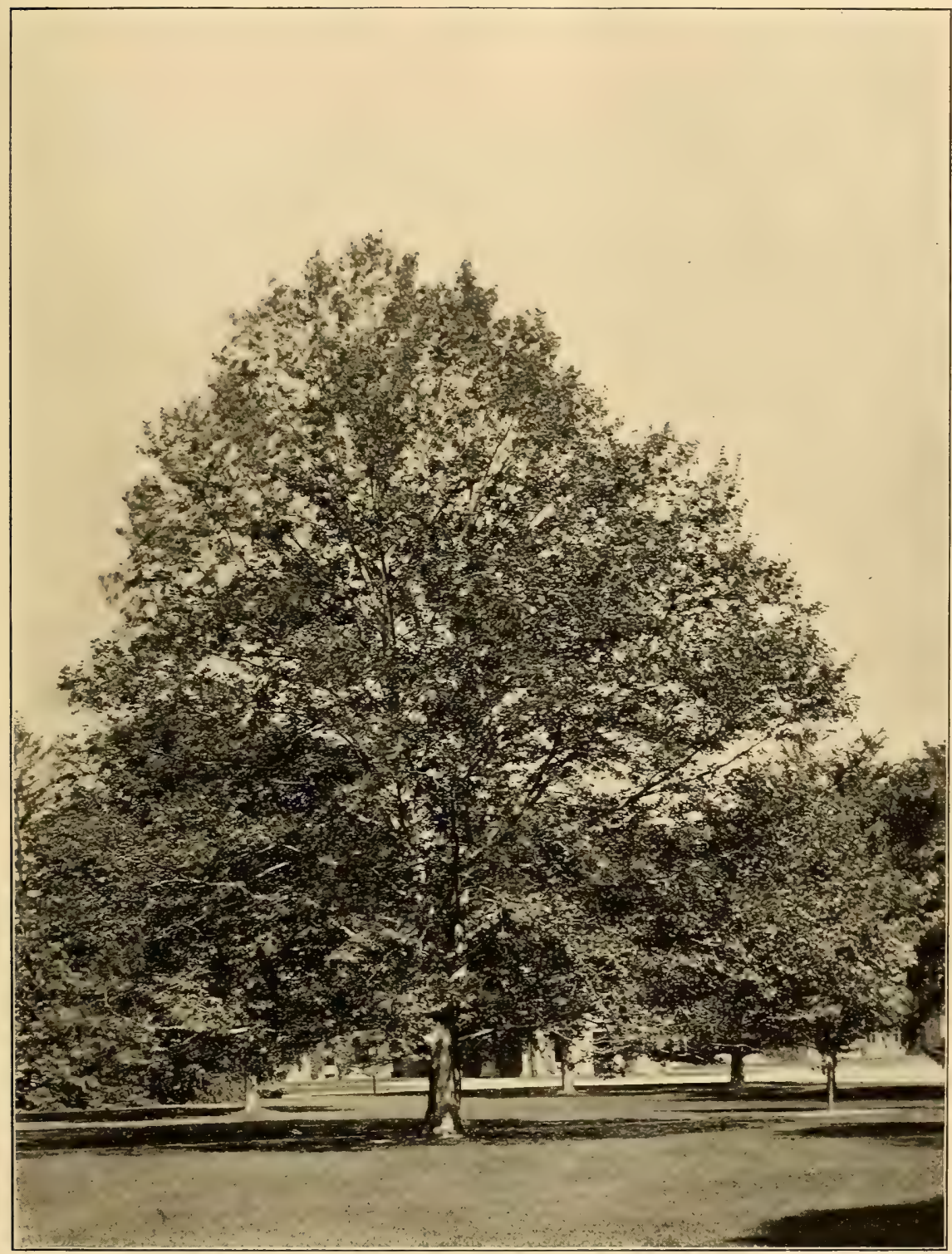

BUTTONWOOD

Vassar College Campus, Poughkeepsie, N. Y. 

the fall the dull red apple-like fruits make the tree very attractive. These miniature apples are about $1 / 2$ inch in diameter and contain usually only 2 stones, imbedded in the greenish flesh.

The tree is of little economic importance except for decorative planting. It is found wild from Lake Champlain to Georgia and westward. It is common in the lower and central Hudson Valley.

The English Hawthorn (Crataegus Oxyacantha) is botanically related to the cock-spur thorn and may be distinguished by its jagged leaves, and its usually single stone imbedded in the yellow flesh. It is known in the Hudson Valley only as an escape from cultivation.

\section{Large-fruited Thorn}

Crataegus punctata

The shallower double-toothing of the leaf-margins of this thorn is very distinct from the toothing of the leaves of the cock-spur thorn. The fruits are brick-red and almost always contain 3 or 4 stones, imbedded in the greenish-yellow flesh. The tree attains a height of 25 feet or more.

It grows from Quebec southward to Georgia and is fairly common along the Hudson Valley.

The waxy thorn (Crataegus pruinosa) is not a very large tree and is found growing from the Thousand Islands to the southern Appalachians. From the preceding sorts it can be distinguished by its leaf-blades which are broadest towards the base. The fruit is waxy and purple-green in color. It is common in the area covered by this list.

Round-leaved Thorn

Crataegus Rotundifolia

This is credited with a distribution further north than any other North American thorn. It is also widespread, growing as far south as Virginia and westward to Wisconsin.

It frequently attains a height of 20 feet and forms a beautiful round-topped tree. The dark red-brown bark is scaly on the trunk but smooth on the twigs. The prickles are from I to 3 inches long and usually curved. The leaf-blades 


\section{( 130$)$}

are oval and roundish in outline and lobed or coarsely doubletoothed on the margins. In late spring the beautiful clusters of white flowers make the tree very attractive. About October the dark red fruits ripen, and they are usually about $\mathrm{I} / 2$ inch in diameter and almost round. Imbedded in the dry yellow flesh are usually 2 to 4 stones.

Thin-leaved Thorn

Crataegus tenuifolia

In early spring this thorn is a conspicuous feature in the landscape as its young leaves are bronze-red. The tree is often 25 feet high or more, and usually has a large round crown. On the trunk the bark is scaly and gray-brown but the twigs are smooth and reddish-brown. The ellipsoid or oval leaf-blades are coarsely double-toothed on the margin, green on the upper surface and somewhat paler on the lower. The leaves have a tendency to be broadest towards their bases. The many-blossomed clusters of flowers are attractive in the early summer, followed in August or September by the small apple-like fruits. These are crimson, pear-shaped or oblong and not more than $3 / 4$ of an inch in diameter. In the acid yellow flesh there are usually 4 , sometimes 3 or 5 , stones imbedded.

The thin-leaved thorn grows wild from western New England to Virginia and westward. It is fairly common in the upper and central part of the Hudson Valley.

The twin-mountain thorn (Crataegus pentandra) differs from the thin-leaved thorn in having mostly 3 stones imbedded in the flesh of the fruit. It rarely exceeds 15 feet in height. It is known to grow in the central part of the Hudson Valley.

Pringle's Thorn

Crataegus Pringlei

This is one of the most variable thorns of the region. The lobing of the leaves is often very different on separate plants but usually the leaf-blades are coarsely double-toothed or lobed. The many-flowered clusters of blossoms are very beautiful in the early summer and the fruit matures later 




SERVICEBERRY

New Baltimore, Greene County, N. Y. 

than that of most of the thorns. It is red, hairy, and is often eaten, but is too acid to be generally liked.

In Dutchess County Pringle's thorn is common but north and south of this it is apparently rare in the valley.

Red-fruited Thorn

Crataegus mollis

This well-known thorn is often called the red haw. It grows from Quebec to Tennessee and westward and is common along the Hudson Valley. It often attains a height of 35 feet and forms a broad round-topped tree.

The broadly oval leaves are sharply and deeply toothed, cut square or heart-shaped at the base and sharp-pointed at the tip. On the upper surface the leaf-blades are finely hairy, and on the lower surface woolly hairy. The curved prickles are not more than $2 \mathrm{~T} / 2$ inches long. After the flowers, which form many-blossomed clusters, mature, the fruits ripen. The latter are usually ripe by September, and have a yellow acid flesh. The outside of the fruit is crimson. There are commonly 5 stones imbedded in the flesh but occasional fruits are found with only 4 stones.

Brainerd's Thorn

Crataegus Brainerdi

So far as the Hudson Valley is concerned this is a localized plant. In the region about Dutchess County it is common, but beyond this it is rare. However it grows freely in western New England and is common in Pennsylvania. From all the preceding thorns it may be distinguished by its fruits. Those previously mentioned have the stones of their fruits without pits, but this sort has its fruit-stones pitted. Individual stones may sometimes be found lacking this characteristic but most of them are at least shallowly pitted.

\section{Long-spined Thorn}

Crataegus macracantha

This is a common and widely dispersed plant. It seldom attains a height of more than 25 feet and forms an irregular, broad head. Its long, curved prickles, frequently exceeding 4 inches, gives the tree its common and technical names. 


\section{( 132 )}

In outline the leaf-blades are oval, sharp-pointed at the base and similarly shaped at the tip. The lower quarter of the leaf-margin is mostly quite smooth, but from this point upwards the margins are conspicuously but finely double-toothed. Towards the tip the teeth often give way to distinct lobes. The many-flowered clusters of blossoms make the tree very attractive for planting. These are followed by the fruits which ripen about September. In outline the fruits are almost perfectly round. Imbedded in the sweet, pulpy, yellow flesh are 2 or 3 stones that are conspicuously and deeply pitted.

\section{Wild Yellow Plum}

Prunus Americana

A tree sometimes reaching a height of 35 feet. The numerous branches are wide spreading and armed with prickly spurs. On the trunk the bark is split up into dark brown plates and on the branches it is reddish and smoother. The elliptic-oval leaves are from 2 to 5 inches long, rounded at the base and rather sharp-pointed at the tip. The leafmargins are finely but sharply toothed. On the upper side the leaf-blade is dark green and smooth while the lower surface is paler and hairy, at least on the nerves or veins.

In May the tree is covered with the profusion of white flowers that has occasioned its popularity for decorative planting. The fruit follows, maturing about the middle of September. It is not quite round, about I inch in diameter and orange or bright red in color. The acid, yellow flesh is not much used, except for preserving, and imbedded in it is the oval, flattened stone.

The tree grows naturally from New York to Florida and westward. In the Hudson Valley it is more common towards the southern end than northward. Beyond its decorative value and the use of the fruits for preserves, the wild yellow plum is of little economic importance.

The common garden plum (Prunus domestica) grows wild in the Hudson Valley only as an escape from cultivation. The flowers appear in April or May with the leaves and its well-known fruit is too familiar to need description. 
If the wild red cherry were a longer-lived tree it would be splendid for decorative planting. Its profusion of early bloom and the great number of bright red fruits make it exceedingly attractive. In favorable places it attains a hieght of 30 feet and a trunk diameter of ro inches. The oblong or lance-shaped leaf-blades are from $3 \frac{\mathrm{T}}{2}$ to 5 inches long, and finely, but doubly, toothed on the margins. In April or May the tree is a riotous mass of bloom, the flowers being arranged several in a cluster. The 5 petals are somewhat broader upward than toward the center of the flower. The round fruits are smooth and bright red, being much eaten by birds, although the flesh is bitter and rather thin. Imbedded in it is the round and slightly rigid stone.

On account of its soft wood the wild red cherry is little used except for fuel. It grows from Newfoundland to Georgia and westward, and is common along the Hudson, particularly northward.

The common sweet cherry (Prunus Avium) is often found growing wild in the eastern states, presumably spread by birds. The plant is a native of Europe.

\section{Wild Cherry}

Padus serotina

The arrangement of the flowers of the wild cherry and the choke cherry is very different from those of the other cherries and plums. Those previously mentioned all have their flowers arranged in clusters with the individual flowerstalks arising several in a bunch. In the wild and choke cherry there is a general flower-stalk, rather long, and attached to this are numerous small individual flower-stalks. The flower cluster is thus oblong and contains from 30 to 40 flowers or even more.

The wild cherry is often 80 feet in height with a trunk covered wtih dark red-brown bark. The oblong-oval leaves are from 2 to 5 inches long and taper-pointed at the tip. Along the margins the leaf-blade is toothed and the teeth are distinctly incurved. The white flowers cover the tree in May 
or June, followed later by a drooping cluster of fruits. These are purple-black when ripe, about $1 / 3$ to $1 / 2$ inch in diameter, and with an astringent flesh in which is imbedded the oblong, pointed stone.

Alcoholic liquors are sometimes flavored with the fruits of the wild cherry, which are also used for preserving. The tree is common from Nova Scotia to Florida and westward, and is plentiful throughout the Hudson Valley.

Choke Cherry

Padus virginiana

The choke cherry is similar to the wild cherry, but usually smaller. In our region it rarely develops a trunk but occasional trees may be found. They never exceed 25 feet. From the flowers of the wild cherry they have practically no distinguishing characters, but the fruit is smaller and reddish instead of black-purple. The teeth of the leaf-margins are not incurved as those of the wild cherry, but spreading. Without seeing either flower or fruit the trees may be distinguished by this character of the marginal teeth of the leaves.

As a shrub the plant flourishes over a large part of the continent but as a tree it is rare. It is common in the Hudson Valley, particularly along roadsides, where its white clusters of flowers make it very attractive in the spring.

Honey Locust

GLEDITSIA TRIACANTHOS

This often forms a magnificent spreading tree that exceeds I 20 feet in height. Its trunk, which is commonly 2 to 4 feet in diameter, is covered with a coarse, brown bark. The zigzag twigs are often armed with stout branching prickles that frequently exceed 4 inches in length. The leaves are doubly compound; that is, there is one main leaf-stalk to which are attached from 4 to 18 pairs of secondary leafstalks and these minor stalks usually have from 7 to Io pairs of leaflets attached to them. All the leaf-stalks are hairy. The leaflets are ovate or elliptic, short-stalked, and not more than $I I / 2$ inches long. They often "fall asleep" at night, 
when they will be found face to face, instead of spread apart. Both sterile and fertile flowers are found on the honey locust, and they are both somewhat irregularly unequal, arranged in finger-shaped clusters and greenish in color. They contain great quantities of nectar and are much visited by bees. The subsequent fruits are pea-like but much longer than ordinary garden peas, frequently exceeding a foot in length. The seeds are flat and oval.

The durability of the wood of the honey locust when underground has made the tree much prized for fence posts and railroad ties. It grows wild from Ontario to Pennsylvania and Florida; most of the trees in the Hudson Valley are presumably naturalized as it seems not to have been ancestrally wild in the valley. To-day it is common.

The locust (Robinia Pseudacacia) is not a wild tree in the Hudson Valley but has become naturalized from its frequent cultivation. Its trunk is covered with deeply-fissured bark, and often forks into several main branches. The flowers are in clusters, white, and are much like a common pea. The pods are quite smooth. Naturally the tree is confined to a narrow belt stretching from southern Pennsylvania to Georgia. Its wood is very hard and durable.

The clammy locust (Robinia viscosa) may be distinguished from the preceding by its smaller stature, red or pinkish flowers, and hairy pods. Its natural range is confined to a small area in Tennessee and North Carolina; the many wild trees in the Hudson Valley are escapes from cultivation.

Staghorn Sumach

RHUS HIRTA

Most of the sumacs are shrubs, but an occasional tree 30 feet high may be found. The bark on the trunk and larger branches is smooth and brown; very rarely it splits up into small plates.

The compound leaves are from 16 inches to 2 feet long, hairy, and composed of from I I to 3 I leaflets, all attached to the common, reddish, or greenish-red leaf-stalk. The leaflets are themselves practically stalkless, lance-shaped or 
oblong and sharp-pointed at the tip. The margins are finely toothed. There are two kinds of flowers, fertile and sterile, and they are usually found on separate trees, but occational trees have both kinds on the same plant. Both kinds of flowers grow in large clusters, and the fertile flowers bloom about ten days later than the sterile. The fruits are in dense clusters, and when ripe the fruit-cluster is covered with a quantity of dark red hairs, thus giving the plant a beautiful color scheme in the early fall and late summer.

This sumac is common throughout the eastern states. The wood is of little value, but the bark and leaves are rich in tannin.

The scarlet sumac (Rhus glabra), a closely allied plant, is smaller than the staghorn sumac and it may be distinguished by its perfectly smooth leaves which are conspicuously whitish on the under side. It, too, is very common, as a shrub, but it rarely becomes a tree in the Hudson Valley.

\section{American Holly}

ILEX OPACA

It is only in the extreme southern part of the Hudson Valley that we find the holly. On Staten Island and Sandy Hook the tree was formerly abundant. In favorable situations it reaches a height of 50 feet and a trunk diameter of 2 feet.

Its well-known, prickly-margined leaves are from 2 to 5 inches long, quite stiff and leathery. There are two kinds of flowers on the holly, fertile and infertile and they are almost never found on the same trees. Both kinds are white and rather inconspicuous. It is mostly from the fertile trees that the Christmas sprays are picked with their profusion of bright red berries. Inside the berries there is a small prominently ribbed stone.

The whiteness and compactness of its wood make the holly desirable for turnery and it is also used in cabinet work and interior finishing. The tree is a slow grower. 
Most of our native maples are large trees, at least 50 feet high or more; but the striped maple and the mountain maple are more frequently shrubby than tree-like. So far as the Hudson Valley is concerned these two kinds, and one other, differentiate themselves, also, from all the other maples by the arrangement of their flowers. In the tall growing kinds there are several flower-stalks that arise at one point, so that there is no real flower-cluster; only several individually stalked flowers. In the striped and mountain maples there is a rather long common flower-stalk which bears numerous stalklets that support the flowers. The whole flower-cluster is often 4 or even 6 inches long.

The striped maple takes its name from the striping of its young bark. It is prominently marked by white or greenishwhite stripes, but these become fainter on the old wood. The broad 3-lobed leaves are often 5 inches long, heartshaped at the base and usually yellowish-green on the upper surface. From the mountain maple it can readily be distinguished by its drooping flower-clusters.

The plant occurs mostly as a shrub within the Hudson Valley, but a few good-sized trees are found in the Catskills and farther north it attains a height of from 30 to 40 feet. South of Kingston it is rare in the Hudson Valley.

\section{Mountain Maple}

ACER SPICATUM

Of the eastern North American maples this species is the smallest. It is usually shrubby and in the Hudson Valley it is doubtful if it attains a greater height than 25 feet. It is a shade-loving plant and in favorable places it is exceedingly common. The leaves are from $3 \frac{1}{2}$ to $4 \mathrm{~T} / 2$ inches long and either 3 -lobed or partially 5 -lobed. The margins of the lobes are coarsely toothed. The comparatively stiff and erect flower-cluster is a prominent feature of the mountain maple and this character serves as a ready distinction between it and the preceding kind. The fruits, as in all maples, are two-winged, to the imaginative suggesting an old time 
key. In the mountain maple they are reddish and the wings are not spreading while in the striped maple the wings are widely spreading and bright green.

The mountain maple is common from northern New York to Georgia and westward. In the Hudson Valley it is very common from the Highlands northward. 'It is too small to be of economic importance.

\section{Silver Maple}

ACER SACCHARINUM

This is one of the most beautiful and widely planted maples used for ornamental purposes. It frequently attains a height of 120 feet and a trunk diameter of 3 feet. On the old trunks the bark is split into thin scales but the young branches are clothed with a smooth bark.

The leaf-blade is roundish in general outline, but is deeply 5 -lobed to beyond the middle. They are bright green on the upper side, whitish or gray beneath. Long before the leaves appear the tree is covered with its flowers. They are greenish-red, but have no petals. Each individual flowerstalk is so short that the flowers appear to be stalkless and attached several together along the sides of the twigs. The typical "key" fruits have widely diverging wings.

The silver maple grows plentifully from New Brunswick to Florida and westward. It is common throughout the Hudson Valley. The brittleness of its wood has limited its use in the arts and manufactures.

\section{Red Maple}

ACER RUBRUM

The natural home of the red maple is in swamp lands, and often in the spring, before the foliage appears, the brilliant red flowers give a characteristic ruddy tinge to many of our swamps. The tree is often I 20 feet in height and with a trunk 3 feet in diameter. On the old branches and trunk the bark splits off in rough plates; the younger branches are smooth-barked. The 3 - or 5-lobed leaves are from 2 to 6 inches long and the lobes are more or less sharp-pointed. The silver maple and the red maple are the only tall kinds 


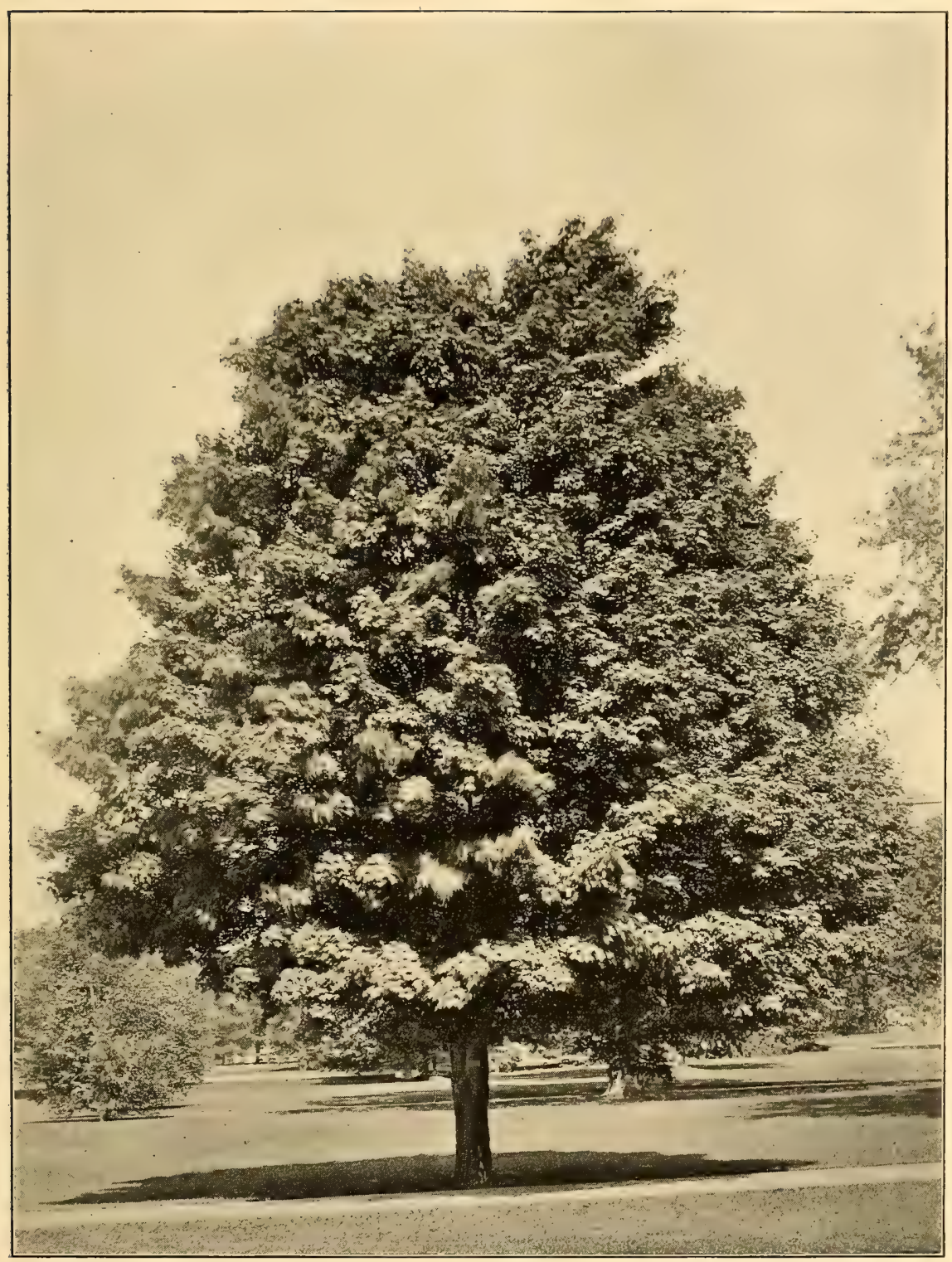

SUGAR MAPLE

Vassar College Campus, Poughkeepsie, N. Y. 

that flower before the leaves develop, and from the former the red maple may be distinguished by its stalked flowers. The fruits are also red, and the foliage turns bright red in the autumn, so the tree is well-named.

Throughout the eastern states the tree is common and in the Hudson Valley it may be found in great quantity. Its wood is largely used in the manufacture of furniture. Scarlet maple and swamp maple are names often used for this tree.

Sugar Maple

ACER SACCHARUM

Maple sugar and maple syrup have made this the most widely known of all our native maples. It rarely exceeds I 20 feet in height, and when perfectly developed it has a great dome-like crown. The brown channelled bark of the old trunk does not split off in plates. The leaf-blades are roundish in outline, 3-or 5-lobed and sometimes as wide as 6 inches across the broadest part. On the upper surface they are dark green, on the lower paler or even bluish-green. Unlike the two preceding kinds the flowers of the sugar maple do not come out until the foliage is well developed. They are greenish-yellow and very conspicuous. The wings of the "key" fruits are almost parallel and strongly veined.

The tree is confined to the region east of the Mississippi and its tributaries, and is common in the Hudson Valley particularly northward. The wood is valuable for decorative finishing of all kinds, and the tree may be annually tapped for its sap, from which maple syrup and sugar are made. From I 2 to $\mathrm{I} 3$ quarts a year per tree is an average yield of syrup. (Plate 147.)

\section{Black Maple}

ACER NIGRUM

In some localities this tree seems to usurp the place of the sugar maple, to which it is very closely allied. In the Hudson Valley the black maple is rare and local. It frequently attains the same stature as the sugar maple and its flowers and fruits are very similar to those of the better known tree. 
The wings of the "key" fruit of the black maple are scarcely parallel, tending, rather, to diverge when old. The most distinctive difference between the two trees is the leaves. In the sugar maple the under-side of the leaf-blades is paler than the upper; in the black maple the leaf is uniformly green throughout.

The black maple grows from Quebec to Georgia and westward. Its wood is used for the same purpose as that of the preceding, and a little sugar is made from its juice.

The Norway maple (Acer platanoides) is our most widely planted foreign maple. In the Hudson Valley it occurs wild only as a very rare escape from street or garden plantations. It is a native of northern Europe.

\section{Ash-leaved Maple}

Acer Negundo

This tree takes its common name from its compound leaves which are somewhat like those of the ash. In the Hudson Valley it is the only maple that has a leaf composed of from 3 to 5 leaflets all joined to a common leaf-stalk. The tree often attains a height of 50 feet or more and the trunk is clothed with a thick-ridged and scaly brown bark. The leaflets, one or two parts of which with a terminal one are attached to a common leaf-stalk, are thin, oval or lanceshaped, and often irregularly or one-sidedly lobed. Either with the leaves or a trifle before them, the bright green flowers bloom. The flowers are without petals, and arranged in clusters similar to those of the striped maple and rock maple. When the tree is in fruit the cluster elongates greatly. The wings of the "key" fruits are divergent at various angles.

The ash-leaved maple grows from New York along the mountains to Alabama and westward. As a wild plant it is not definitely known in the Hudson Valley but it may be found in the northern part and it is much planted for ornament. The wood is soft and weak and is used to a limited extent in the manufactures. Paper pulp is made from it. 


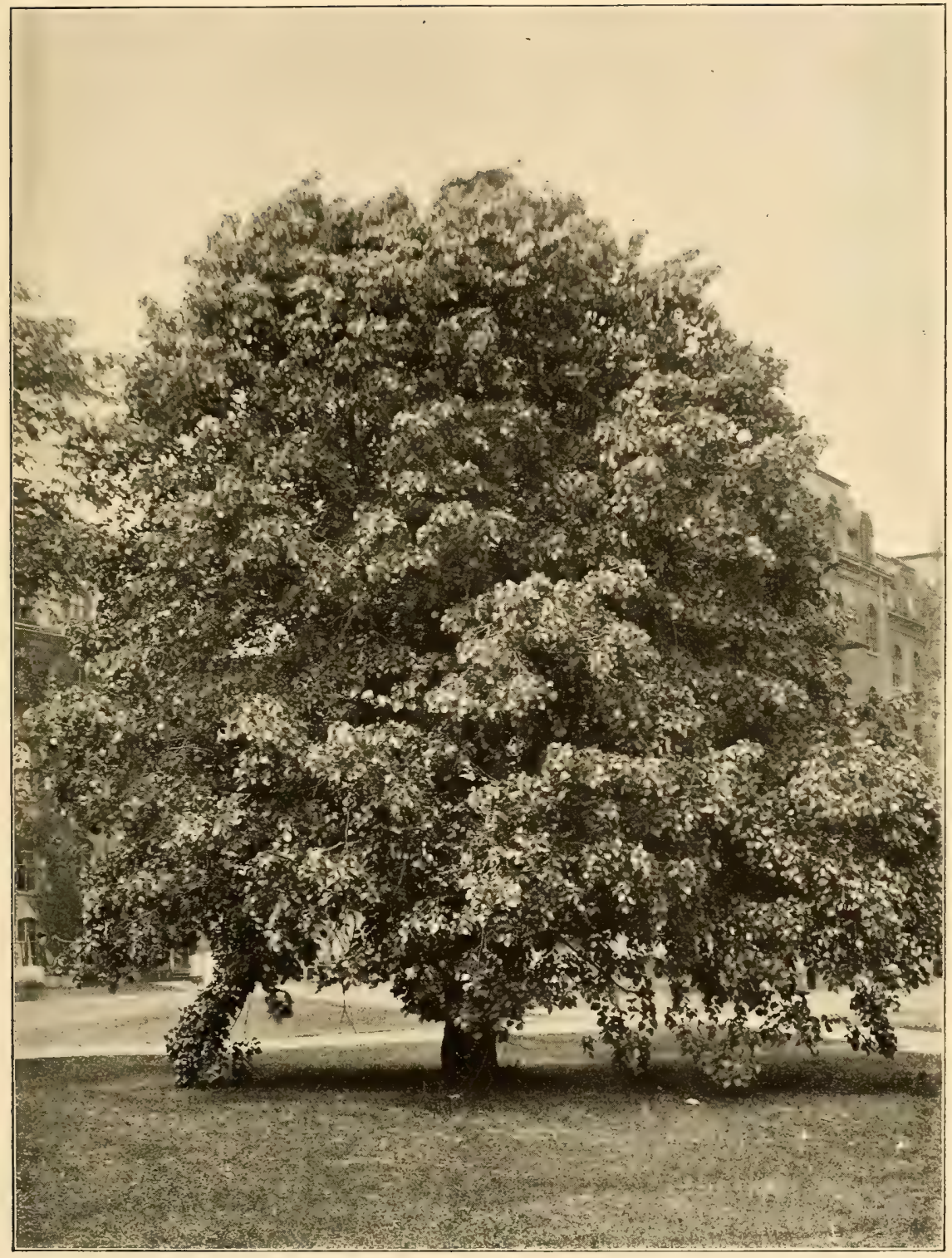

AMERICAN LINDEN

Vassar College Campus, Poughkeepsie, N. Y. 

American Linden

Tilia americana

When growing in the open the linden is apt to develop into a broad round-topped tree, but in the forest it is taller and more slender, often attaining height of $\mathrm{I}$ Io feet and a trunk diameter of 3 feet. The old bark is dark gray and furrowed into flat ridges. In outline the leaf-blades are oval or roundish, sharp-pointed at the tip and more or less unequally heart-shaped at the base. The blade is from 5 to 8 inches long and about $2 / 3$ as wide.

The stalk of the flower-clusters in the linden tree are peculiar, and make it comparatively easy to distinguish it from all the other trees of the Hudson Valley. To the lower third or half of the flower-stalk is fastened a leaf-like organ which is from 5 to 8 inches long and about $1 / 5$ as wide. These leaf-like flower-bearing organs occur indiscriminately mixed with the true leaves. There are from 5 to 20 flowers in a cluster, and they subsequently develop into the ovoid fruit containing a good sized seed.

The tree grows naturally from New Brunswick to Georgia and westward. It is common all along the Hudson. The soft wood is largely used for furniture, carriages, and woodenware; it is also a productive source of wood-pulp for paper manufacture. (Plate I48.)

\section{Hercules Club}

Aralia spinosa

In the south this plant often becomes a tree 25 feet or more in height. Towards its northernmost limit it becomes increasingly scarce. A few small trees have been found in the extreme southern part of the Hudson Valley, which may, however, have escaped from cultivation. All the woody parts of the plant are covered with short stout prickles. There is some popular misunderstanding of the leaves of the Hercules club. The leaf is very large and composed of a great many leaflets, which are attached to leaf-stalks that are themselves joined to the main or central leaf-stalk. The whole leaf is from 2 to 4 feet long; the leaflets scarcely more than 3 or 4 inches long, oval, thick and sharp-pointed. The 
midrib on the under-side of the leaflets is often prickly. There is a huge flower-cluster sometimes 4 feet long, composed of hundreds of tiny white flowers. The fruits are black.

The tree is valuable for its decorative effect, but the wood is soft and weak.

Sour Gum

Nyssa Sylvatica

This tree is often known as tupelo and pepperidge, and loves moist swampy places. It grows commonly in such situations from Maine to Florida and westward and under favorable conditions it attains a height of 140 feet. The branches are widely spreading and often the lower branches are conspicuously drooping. The leaves which turn brilliant crimson in the autumn, are more or less oval in outline, but usually broadest above the middle. They are taper-pointed at the tip, roundish at the base, and from $2 \mathrm{r} / 2$ to 6 inches long. There are two kinds of flowers which appear about May. The sterile flowers are arranged in many-blossomed clusters, the fertile or fruit-producing in clusters of 3 . The dark blue or purple fruits, usually arranged in clusters of 3 , are about $1 / 2$ inch in diameter and contain a many-ribbed stone.

The wood of the sour gum is soft, but very tough and hard to split. For this reason it is much used in making wheels, rollers and ox-yokes. The sour gum requires a moist situation for favorable development, and if such a place can be found for it the tree is well worth planting for decorative effect. (Plate 149.)

Flowering Dogwood

CyNOXYLON FLORIDUM

This tree scarcely ever exceeds 40 feet in height, but it is one of the most showy and popular trees of the eastern states. The old bark is dark brown or nearly black in color, and is split up into small scales or plates. The leaf-blades are oval or elliptic in outline, and more or less sharp-pointed at both ends. The leaf-margins are shallowly toothed or quite smooth. 


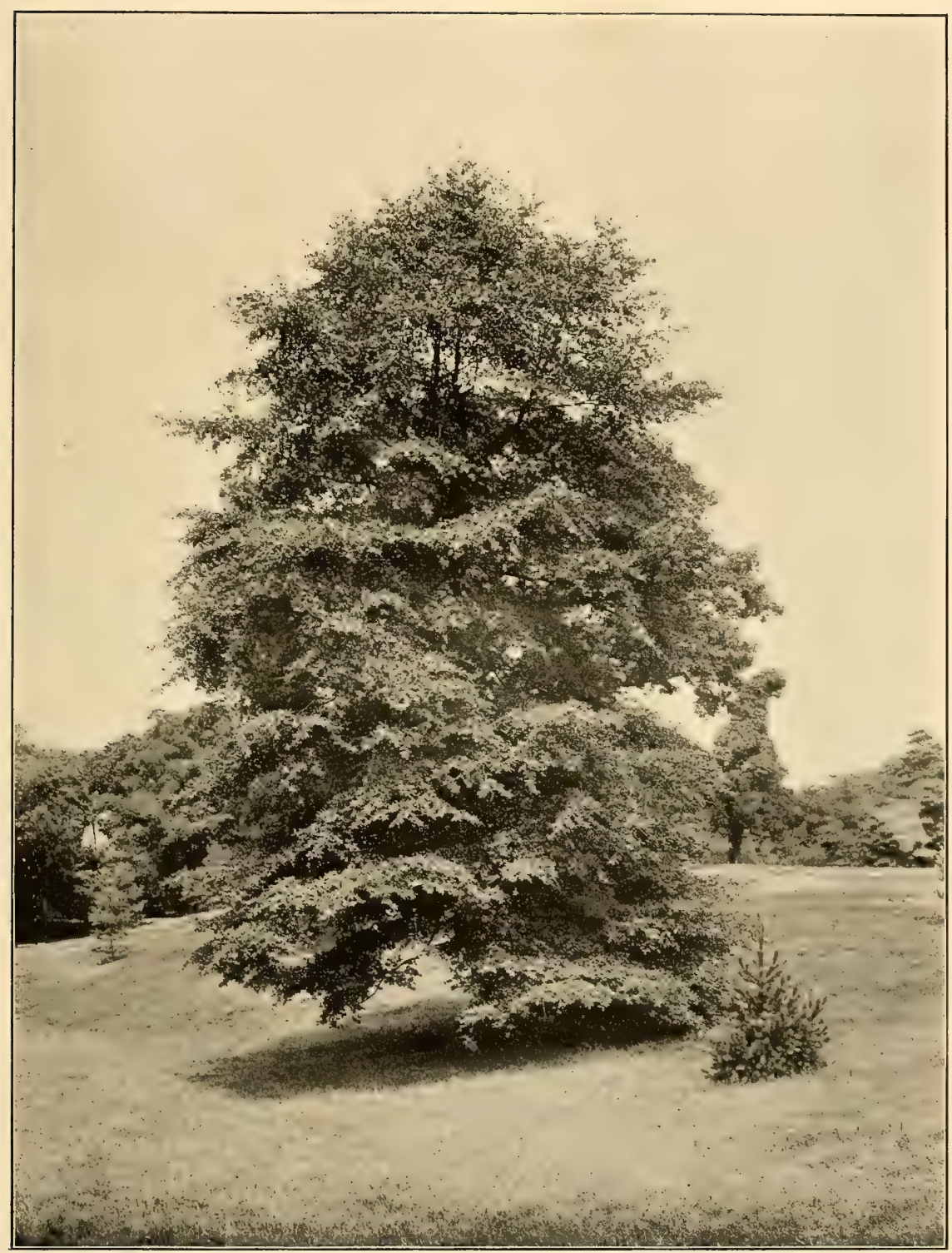

SOUR GUM

New York Botanical Garden 

In early spring the tree is covered with what appear to be large white flowers. There are 4 of these petal-like leaves, each one notched at the tip, and they are really nothing more than a sheath which covers the small greenish flowers. These may be found at the point where the large white, petal-like leaves converge, and after the latter have withered the true flowers bloom. They are followed later by the bright red fruits which contain a hard stone.

Owing to its showy whiteness in the spring and the beauty of its branching the dogwood is much planted in lawns and parks. It grows wild from Massachusetts and Ontario to Florida and west; and is very common throughout the Hudson Valley. Its wood is much used in making parts of machinery, and tool-handles.

\section{Persimmon}

DIOSPYROS VIRGINIANA

It is only in the southern part of the Hudson Valley that we find the persimmon. Its range of distribution is from Rhode Island to Florida and westward, and it is only near Long Island Sound, on Staten Island and adjacent New Jersey that the tree is known to occur with us. Here they are scarce and local. In the north the tree is never more than 40 to 50 feet in height, but southward it becomes twice this size. The thick bark is dark brown or almost black, and somewhat irregularly fissured. When very young the leaves are hairy but they are quite smooth in age. In outline they are oval or oblong and from 3 to 7 inches long, sharp-pointed at the tip and more or less rounded at the base. There are two sorts of flowers, appearing about May or June. The fertile are solitary and the infertile are arranged in little clusters; both are greenish in color. The fruit is orange or reddish-orange in color, about an inch in diameter, and often persists late into the winter. The wood is used for the manufacture of shoe-lasts.

When growing in its favorite habitat the black ash attains 


\section{( 144 )}

a height of 90 feet and a trunk diameter of 20 inches, but most of the trees in the Hudson Valley are smaller than this. The thin, scaly bark is gray in color, and slightly fissured. The compound leaves are from 10 to 16 inches long and are composed of from 7 to I I leaflets. The latter are practically without stalks and this characteristic is peculiar to this ash, all the other Hudson Valley ashes having stalked leaflets. The flowers are borne in many-flowered clusters. The individual flowers are without petals or covering of any kind. The fruits are clustered and each one is surrounded by a wing, the upper end of which is notched.

The wood of the black ash is very durable underground and it is much used for fence posts. It is also used in basketmaking, interior finishing and cabinet-work.

\section{Red Ash}

Fraxinus PENNSYlVANica

This common and widely dispersed tree grows from Vermont to Florida and westward, and is plentiful throughout the Hudson Valley. Its average height is from 50 to 60 feet, and it not infrequently attains a trunk diameter of 5 feet. The bark is thick and furrowed, and usually brownish in color.

In the red ash there are 5,7 , or 9 thin, finely toothed leaflets that compose the compound leaf. They are in pairs, with a terminal one, and each leaflet is distinctly stalked, green on both sides, and from $\mathrm{I} / 2$ to $2 \mathrm{I} / 2$ inches long. In this ash the fertile and sterile flowers are borne on different trees. In both the sterile and fertile there are no petals and the flowers are greenish in color. From the fertile flowers subsequently develop the fruits which are winged; the wing is broader above the middle than below it and slightly notched at its tip. It may be from $I$ to 2 inches long.

The wood of the red ash is much used in carpentry and wagon building, and the tree is desirable for street planting as it grows rapidly. (Plate I 50.)

Darlington's Ash (Fraxinus Darlingtonii), a tree related to the red ash, is known to grow wild from Massachusetts to 


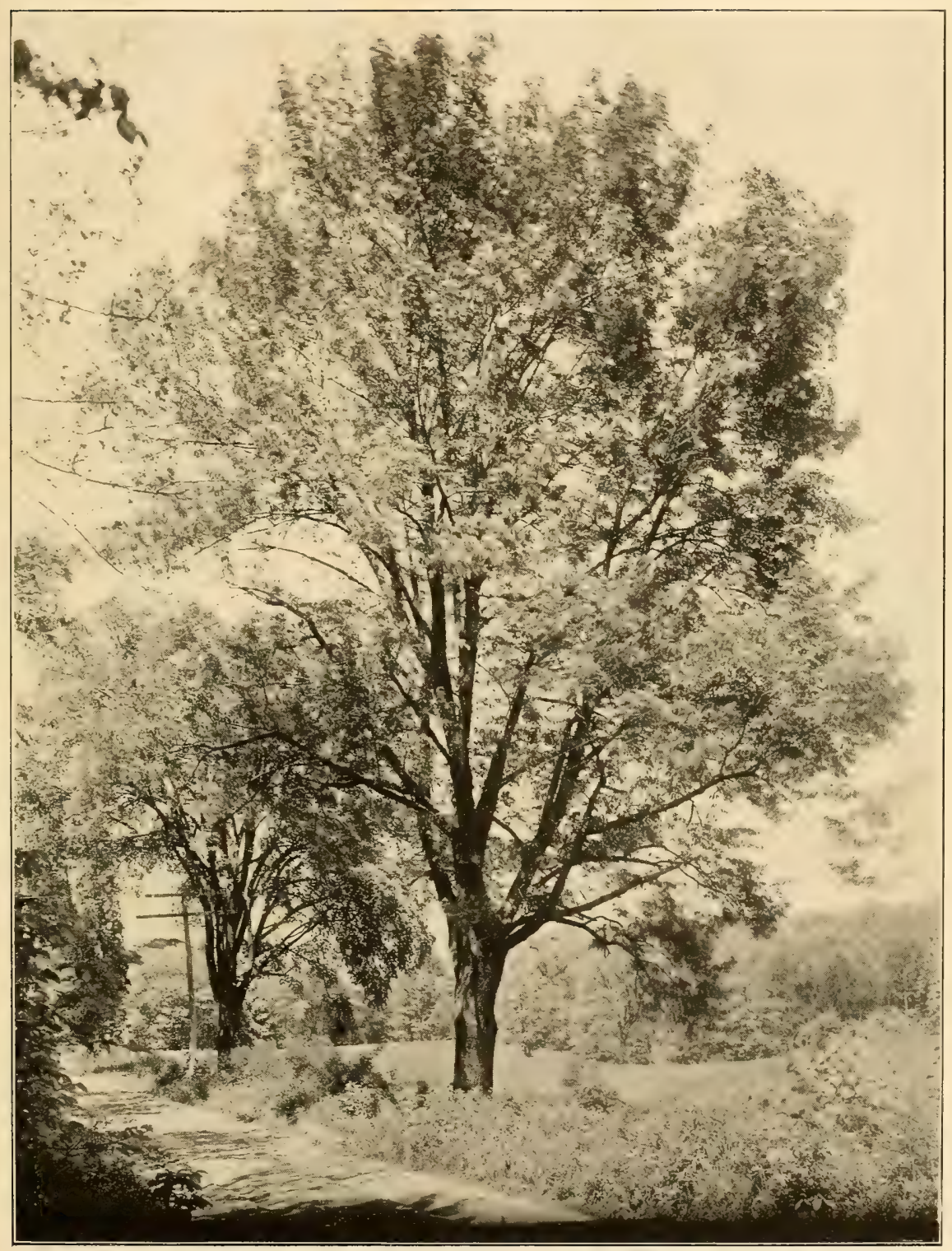

RED ASH

New Baltimore, Greene County, N. Y. 



\section{( 145 )}

central New York and southward, and may be distinguished by its fruits. In Darlington's ash the wings of the fruit are narrow, and practically parallel-sided, while in the red ash the wings are broader above the middle, the sides of the wing converge downward, and they are not parallel.

Michaux's Ash

Fraxinus MichauxiI

As yet this tree is little known and its distribution not fully determined. It is known to grow from southern New York to North Carolina and specimens grow in the grounds of New York Botanical Garden, at Closter, New Jersey, and on Staten Island. Its general features resemble the red ash and its chief distinctive characteristics are the greater thickness of its leaflets and the greater width of the fruit. Their margins are practically smooth while in the red ash the margins of the leaflet are more or less toothed, except in rare instances.

\section{White Ash}

Fraxinus Americana

Probably the best known and one of the most widely distributed of our native ashes. The tree prefers rich hillsides and in such situations often reaches a height of $\mathrm{I} 20$ feet. Its bark is thick, grayish-brown and irregularly fissured.

There may be from 5 to 9 , usually 7 , leaflets composing the compound leaf and each leaflet is distinctly stalked. They are sharp-pointed at the tip, rounded or acutish at the base, from 3 to 6 inches long and fine toothed or smooth on the margins. The under face of the leaflet is paler than the upper and is either hairy or quite smooth. As in the red ash the fertile and infertile flowers are, in the majority of cases, borne on different trees. Sometimes, however, both kinds of flowers may be found on the same tree, but in different flower-clusters. The fruits are winged above and the margins of the wing are either parallel or converge slightly downward. The seed-bearing part of the fruit is full and round, the wing arising from its upper end, and not running down the side of the seed. 
Button Bush

Cephalanthus occidentalis

Almost all the plants of the button bush are shrubs, but occasional trees may be found. In the grounds of the New York Botanical Garden a plant was cut out that had died, apparently from old age, which was a good sized tree of 25 feet or more. On old trunks the bark is dark brown or nearly black, and deeply fissured. The leaves are arranged in pairs or threes on the twigs. The blade is oval in outline, sharp-pointed at the tip and rounded or wedge-shaped at the base. In July the compact, ball-like clusters of creamy white flowers almost cover the plant. The fruits ripen late in the autumn and are arranged in densely compact ball-like heads, usually $3 / 4$ of an inch in diameter.

The button bush prefers swamps and the edges of streams and is common over the greater part of the United States. In the Hudson Valley it is common, but mostly as a shrub.

\section{Sweet Viburnum}

ViBURNUM LENTAGo

This plant is often known as nannyberry and grows in rich soil from Ontario to Georgia and westward. It is common in the Hudson Valley, where it occurs as a shrub or a tree in about equal proportions. As a tree it reaches a maximum height of 30 feet and a trunk diameter of 8 to Io inches.

The leaves, which are in pairs along the twigs, are bright green, smooth on both sides, oval or elliptic in outline, very rarely becoming roundish. The margins are sharply toothed, and the leaf-blade is $2 \mathrm{I} / 2$ to $5 \mathrm{~T} / 2$ inches in length from its sharp-pointed base to the taper-pointed tip. The small white flowers are borne in large, almost stalkless clusters, and the collection of petals in the individual flowers are united at their bases.

In September its buish-black edible fruits ripen. They are scarcely $1 / 2$ inch in diameter, covered with a bloom and contain a flat oval stone. The beauty of its autumnal foliage makes the plant desirable for decorative effects. Otherwise it is of little economic importance. 


\section{( 147 )}

Black Haw

VIBURNUM PRUNIFOLIUM

The black haw is more frequently a shrub than a real tree, although occasional specimens attain a height of 30 feet. It grows from Connecticut to Georgia and westward, and is very common along the lower Hudson, more rare northward. The stiff, spreading branches are usually armed with numerous prickle-like branchlets. The leaf-blades are smooth, from $I \frac{1}{2}$ to 4 inches long, and essentially oval in outline. They are somewhat sharp-pointed at both ends and the margins are finely toothed. They are not taper-pointed at the tip and this serves as the chief distinction between it and the nannyberry. As in that species the flowers are arranged in an essentially stalkless flower-cluster. The petals are white and united below. The fruit is much the same as that of the nannyberry and is edible, usually being most prized after it has been frozen.

The plant is greatly in demand for decorative effects, and the bark of the roots and trunk is astringent. The wood is brittle and of little economic importance. 


\section{INDEX}

Abelia, Chinese, 73

Abies, 4I balsamea, 96

Abutilon fiber, 2x

Acacia, Australian, 15 three-horned, 80

Acalypha hispida, ro

Acanthopanax, Maximowicz's, 7 I

Acanthorhiza aculeata, 4

Acanthus Family, 59

Access, means of, $x$

Acer, $8 \mathrm{r}$

Negundo, 140

nigrum, 139

pennsylvanicum, 137

platanoides, 140

rubrum, $\mathrm{x}_{3} 8$

saccharinum, $\mathbf{1}_{3} 8$

saccharum, 139

spicatum, 137

Acids, vegetable, 24

Aconite, 26, 52

Acrocomia media, 4

Aceranthes, two-leaved, 52

Actinidia Family, 63 toothed, 63

Adam's needle, 49

Adelia, 72

Aesculus, 8I

Agaric, white, 25

Agathosma apiculata, 14

A gave, 5, 8

americana, 8

Queen Victoria's, 8

sisalana, 8

thread-bearing, 8

Agrimony, 53

Ailanthus, 80

Family, 80

Akebia Family, 63

five-leaved, 63

Albuminoids, 24

Alder, 65, 76, 77, IIO, III

dye, 77

European tree, 77

hoary, 77

Japanese, 77

New York, I Io

smooth, 65

speckled, 77

white, $7 \mathrm{I}$

Family, 7 I
Algae, 28, 30

blue-green, 28

brown, 28

fossil, 36

green, 28

red, 28

Alkanet root, 22

Alkaloids, vegetable, 24

Allamanda, 7

Henderson's, 7

Allspice, 22

Almond, 23, 25, 26

Russian, 68

Alnus noveboracensis, 1 ro

Aloe, 7,8

Alum root, 53

Amaranth Family, 50

Amaroids, 24

Amaryllis Family, 5, 14, 16, 49

Amelanchier canadensis, 127 intermedia, 128

Amsonia, willow-leaved, 57 broad-leaved, 57

Andreaea, $3 \mathbf{I}$

Anemone, 52

Angelica tree, Japanese, $7 \mathbf{r}$ variegated Chinese, $7 \mathrm{I}$

Angiosperms, 32 fossil, 37

Anice, star, 26

Anona cherimolia, 9 muricata, 9

Anthocerotes, 30

Anthurium, $7 \mathbf{I}$ Veitchii, 6

Apple, 25, 68, 126

crab, 79, 127

American, I26

prune-leaved, 80

Siberian, 79

Soulard's, 8o

European, 126

Family, 68, 79, 80

thorn, 68

true, 79

Apricot, 68

Aquatic leaves, 6I

plants, ro, Ir, 47

roots, $6 \mathrm{I}$

stems, 6I

Araceae, $\mathbf{x}$ I

Aralia, 82, I4I

heart-leaved, 56 


\section{( I49)}

Aralia spinosa, I4I

Araucaria, 14

Bidwillii, $\mathbf{I}_{4}$

brasiliana, 14

excelsa, 14

Arboretum, deciduous, 3, 74

Arborvitae, 46, 97

Chinese, 46

common, 46

Japanese, 46

Aroid Family, 6, II

Aroids, II

Arrow-arum, green, 48

Arrow-grass Family, 48

Arrow Head, 48

-root, 5,24

Family, 5

flour, 24

-wood, 73

coast, 73

Artemisia, 60, 74

Artichoke, Jerusalem, 25, 60

Artocarpus incisa, 6

Arum Family, 48 arrow-, green, 48

Asarum, 50

Ascobolus, 33

Ash, 82, 143-145

American mountain, 126

black, I43, I44

Biltmore, 82

Darlington's, I44, I45

European, 82

green, 82

Michaux's, I45

mountain, American, 126

prickly, 69

red, 82, x44, I45

Texas, 82

white, 82, 145

Asparagus, 25, 49

Aspen, 100, I0I

American, 75, 100, I0I

large-toothed, IOI quaking, roo

Asphodel, 49

Aster, 60

Aucuba japonica, $\mathbf{6}$

Australian plants, I4

Avens, 53

Azalea, $7 \mathrm{I}$

\section{Baccharis, 74}

Bacteria, 27

Balm, horse, 58 of Gilead, 99

Balsam, 55

Canada, 4r, 96

fir, 96
Balsam of fir, $4 \mathbf{x}$

Bamboo, 4, ro Chinese, 4

Bambusa vulgaris, 4

Banana, 12, 12, 24, 25

Family, 12, 13

flour, 24

Banyan tree, 6

Baptisia, 54

Barbados nut, ro, 26

Barberry, 65, 66

European, 65

Family, 52, 65

large-toothed, 66

neat, 65

Thunberg's, 65

Basswood, 82

Bay, 22

Bayberry, 64 Family, 64

Beard-tongue, $5^{8}$

Bean, 25, 54

calabar, 26

Indian, 82

Tonka, 26

Bedstraw, 59

Beech, 78, 83, III

American, 78, III

copper, III

European, 78, III purple-leaved, 78

Beet, 25 Family, 65, 77

sugar, 25

-tops, 25

Beer, 23

birch, 109

Begonia, ro

foliosa, ro

nelumbiifolia, ro

Rex, ro

rotundifolia, ro

Bell flower, Carpathian, 5c

creeping, 59

Family, 59

Hosts, 59

Japanese, 59

Bellwort, 49

Benzoin, 66

Bergamot, 58

Betel nut, 26

Betony, 58

Betul oil, 109

Betula, 76 alleghanensis, 1 ro

lenta, ro9

lutea, rog

nigra, 108

papyriferz, 108 


\section{( 150$)$}

Betula populifolia, xo7

Beverages, 22 alcoholic, 23

malt, 23

non-alcoholic, 22

Bicuculla, 52

Bindweed, 63 small, 57

Birch, 23, 26, 76, 107-1 10

beer, 109

black, 77 , ro9

canoe, 76 , 108

cherry, ro9, 1 I0

Family, 65, 76

gray, 107, 108 paper, 76, 107, 108

poplar-leaved, 77

red, 76

river, $76,108, \mathrm{rro}$

sweet, $77,83,109$

white, European, 76

American, 76

Japanese, 76

yellow, 76, 109, 1 го

southern, I ro

Bird-of-Paradise plant, $\mathbf{I}_{3}$

Birthwort Family, 50, 63

Bishop's cap, two-leaved, 53

Bitternut, 26, ro4

Bittersweet, 26, 63

Blackberry, 53, 67

Black lead, 36

Bladder green, 70

-nut, 70

Family, 70

senna, woody, 69

Bleeding heart, 52 wild, 52

Bluets, 59

Bocconia, cordate, 52

Boehmeria nivea, ro

Boneset, 26, 60

Borage Family, 57 flowers, 26

Border screens, 87

Bottle-brush, 15

$$
\text { tree, } 15
$$

Bougainvillaea, I6

Box, 55

elder, 8r

Family, 54, 69

tree, 69

Bracken, 47

Brake, 47

Bread-fruit, 6 Kafir, I 8

Bridges, 86

Brier, cat-, 62

green-, 62
Brier, sweet-, 67

wild, 67

Bromelia Pinguin, 12

Bronx River, 3 gorge of, 3,84

Broom, common, 68 dense-flowered, 68 white, 68

Brunnichia, 63

Bryophyta, 27, 30

Buckbean, 26

Family, 57

Buckeye, 70, 82

Family, 70, 8I

fetid, 82

Ohio, 82

small-flowered, 70

Buckthorn, Dahurian, 70

Family, 70

purging, 70

sea, 7 I

Buckwheat, 50

Family, 50, 63

Buddleia, 72

variable, 72

Buffalo berry, $7 \mathbf{I}$

Bullrush, 48

Bunchflower Family, 49

Burdock, 60

Burgundy pitch, 42

Burnet, 53

Burning bush, 69

Burr-reed Family, 48

Bush clover, 22, 54 two-colored, 68

Buttercup, 52

Butternut, 76, 102, 103

Button-ball, 79, 126

Button-bush, I46

Button-wood, 79, 125

Buxus, 55

Cactus, 7-9, 55

Family, 7, 10, 55

hedgehog, 9

Turk's-head, 7

Calamites, 36

Calamus, 23, 26 buds, 25

Calathea, 5

Calcareous tufa, 3 I

Calla lily, II

Callicarpa, Japanese, 72 purple, 72

Callistemon citrinus, 15

Camphor, 15 tree, 15

Camellia, 15, 70

Candy-tuft, 52 
Candy-tuft, evergreen, 52

Canterbury bells, 59

Canna Family, 12, 50

Canthoceros, 70

Caper Family, 52

Caraway, 23, 56 seed, 22

Cardamon, 26

Cardinal flower, 6o blue, 60

Carex, 48

Carludovica palmata, 4

Carnegiea, 7 gigantea, 9

Carrion flower, 7

Carpet-weed, $5 \mathrm{I}$ Family, 5I

Carpinus caroliniana, 106

Carrot, 25, 56 Family, 56, 57 wild, 56

Cascara, 26

Cassava plant, 24 flour, 24 starch, 24

Cassia, 54

Castalia, II

Castanea, 78 dentata, 112

Castor oil, 23 plant, 23 seed, 23,26

Catalpa, 82 Kaempferi, 82

Cat-brier, 62

Catchfly, $5 \mathbf{I}$

Catnip, 58

Cat's-foot, 60

Cat-tail Family, 48

Cauliflower, 25

Cedar, 23, 96-98 bastard Chinese, 80

Deodar, 44

Indian, 44

Japanese, 44

low, 45

Mt. Atlas, 44

red, $23,45,96,98$

stinking, I4

Celery, 56 white, $46,97,98$

seed, 22

Celtis, 78 crassifolia, 122 occidentalis, $\mathbf{x 2 2}$

Century plant, 5,8

Cephalanthus occidentalis, $\mathbf{1} 46$

Cephalaria, 59

Cephalotaxus, 45
Cereus, 7

giant, 9

Cercis-leaf, 65,79

Family, 65, 66, 79

Cercidiphyllum, 65

Ceropegia Sandersoni, I6

Cestrum Parqui, 7

Chamaecyparis, 45 obtusa, 45

pisifera, 45

thyoides, 98

Chamomile, German, 26

Roman, 26

Charcoal, I07, 115

Chenille plant, 9

Chenopodium, 50

Cherimoyer, 9

Cherry, 68, I33 choke, I33, 134 ever-blooming, 80

Japanese flowering, 80

rose-bud, 80

sweet, 80

common, I33

western sand, 68

wild, 26, 133,134

red, 133

Chestnut, 25, 77, 78, 83, II 2, I17

American, 78 , $\mathrm{rI} 2$

horse-, 26, 70, 8I

Japanese, 78

Chewing gum, 22

Chickweed, 5 I

Chicle-gum, 22

Chicory Family, 60

Chimonanthus, 66

Chinquapin, 65

Choke berry, 68

Chocolate, 6, 22, 23

beans, 6

fruit, 23

germs, 23

nibs, 23

seeds, 23

tree, 6,23

Chrysanthemum, 60

Cibotium Barometz, I9

Cinchona, 26

Cinquefoil, 53

Cinnamon, 22, 23, 26

Cinnamomum Camphora, 15

City ordinances, 88,89

Clammy weed, 52

Clerodendron, late flowering, 72

Clot burr, 6o

Cloth, 2I grass, to

Clover, 54 bush, 22, 54 


\section{( 152$)$}

Clover, red, fiowers of, 26

Cloves, 22, 23

Coal, 36,38

Coca, 26

Cocaine plant, 9

Cochineal, 8 insect, 8

Cocoa, 6, 23 breakfast, 23

-butter, 23

cake, 23

liquor, 23

Coco de Mer, I7 des Maldives, 17

Cocos Weddelliana, 4

Cocothrinax argentea, 4

Codiaeum, xo

Coffee, 22, 59 -tree, Kentucky, 80

Cohosh, blue, 52

Colchicum, 26

Colic root, 26

Colocynth, 26

Colt's foot, 60

Columbine, 52, 87

Comfrey, 57 rough, 57 tuberous, 57

Compound-leaved plants, 60

Cone-bearing plants, 32 fossil, 35-37. trees, collection of, 40

Cone-flower, 6o, 87

Conifers, resin of, 22

Conservatories, 2-19

Conservatory court, 17

Convallaria, 49

Coontie, 18, 24 flour, 24

Copaiba, 9 tree, 9

Copaiva officinalis, 9

Coral, 36

Corallines, 28

Cordaites, 36

Coreopsis, 87

Coriander, 22

Cork, 24 -tree, Chinese, 80 Japanese, 80

Corn, 24, 25

Cornel, 7 I

Cornus, $7 \mathbf{I}$

Corokia Cotoneaster, 16

Corylopsis, 67

Costus, 13

Cotinus, 69

Cotton, 21 plant, 2 I
Cotton oil, 23

seed, 23

-wood, 74, 75 eastern, 75

Cowslip, 56

Cranberry-tree, 72 dwarf, 72

Cranesbill, 54

Crataegus Brainerdi, $13 \mathbf{I}$ Crus-galli, 128

macracantha, $13 \mathrm{I}$

mollis, $\mathbf{x}_{3} \mathbf{I}$

Oxyacantha, 129

Pringlei, 130

pruinosa, 129

pentandra, 130

punctata, 129

rotundifolia, 129

tenuifolia, 130

Creeping charlie, 56

Creosote, III

Crinum, 5

Crocus, 87

Croton, Io

Crowfoot Family, 52, 65, 66

Cubebs, 26

Cucumber, 63 one-seeded bur, 63 star, 63

Culver's root, 58

Cupressus, 44

Currant, 66, 67 golden, 66

Custard-apple Family, 9

Cycadofiliacales, 36

Cycads, 18 fossil, 35,37

Cycas circinalis, $\mathbf{x} 8$ revoluta, 18

Cyclanthus Family, 4

Cynoxylon floridum, 142

Cyperus Papyrus, Io

Cypress, 44

American, 44

bald, 44

Hinopi, 45

pond, 44

Sawara, 45

swamps, 44

Daffodil, 49, 87

Dasylirion, 8

Date palm, 4

plum, 82

Trebizond, 7 I

Day flower, 49

lily, 49

Deal, white, 42

Deciduous arboretum, 74

Decodon, 55 
Delphinium, 26

Dendrology, North American, 20

Dendrophycus, 36

Desert plants, 7-9, 17, 60, 6r

Deutzia, 66 slender, 66

Diatoms, 28, 33

Dicotyledons, $32,47,50$ fossil, 35

Dictyolites, 36

Diervilla, 73

Digitalin, 58

Digitalis, 58

Diospyros, 82

Dirca, $7 x$ virginiana, 143

Dittany, 58

Dock, 50

Dogbane Family, 21, 57

Dog-berry, $7 \mathrm{I}$

Dog-rose, 67

Dog-wood, 71, 83, I42, I43

Family, I6, 7 I

flowering, 16,142 officinal, 7 I

panicled, $7 \mathrm{I}$

red-osier, $7 \mathrm{I}$

Douglas spruce, 40, 4r

Dracaena, 5

Dragon, green, 48

Drainage, 87 -head, false, $5^{8}$

Drosera, 14

Drugs, 20, 25 crude, 26

Duckweed, 48 Family, 48

Dutchman's pipe. 63

Dye stuffs, 22

Ebony Family, 82

Echeveria, 8

Echinocactus, 7

Economic botany, museum of, 20 garden, 3, 62

Egg plant, 58

Elderberry, 73 box, $8 \mathbf{r}$

Elecampane, 22, 60

Elemi, 23

Elm, 78, 79, 120, 12I

American, 78, 120, 121

Chinese, 78

cork, 78, I2I

dwarf, 65

English, 121

Family, 65,78

late-flowering, 78

rock, 78
Elm, Scotch, 78

slippery, $26,78,120, \mathbf{2 2 1}$

water, 78 pointed, 78

white, 120

winged, 78

Wych, 78

Encephalartos, 18

Endogenous plants, 13, 14. 47

Entrances, 85

Enzymes, 24

Epimedium, red; 52

Epiphytes, II, 16

Equisetum, 31, 34

Ergot, 25

Erythroxylon Coca, 9

Eucalyptus, 15, 23, 26

Euonymus, 69

Evening primrose, 56

$$
\text { Family, } 56
$$

Exochorda, large-flowered, 67

Exogenous plants, 13, I4, 47

Fagus, 78 grandifolia, III sylvatica, III

Fennel, 23

Fern, II, I3, I8, 19, 27, 31, 32, 47 cinnamon, 47

Clayton's, 47

floating, II

fossil, 36,37

lady, 47

leaf stalk of, 34

ostrich, 47

root of, 34

royal, 47

American, 47

shield, 47

staghorn, 19

sweet, 64

tree, 16 , 19

Feverwort 59

Fibers, 20, 2r, 25

articles manufactured from, $2 \mathrm{I}$

plants, 62

wood, 24

Ficus, 6

benghalensis, 6

Carica, 15

elastica, 6

Fig, 6, 15

-marigold, 9, 5 I

Roxburgh's, 6

Figwort, 58 Family, 58, 82

Filbert, 65

Fir, 4I, 42, 96 balsam, 4r, 96 


\section{( I 54)}

Fir, red, 41, 42

Siberian, 42

silver, 42 Japanese, $4 \mathrm{I}$

Nikko, 42

Nordman's 42

Sicilian, 42

Vietch's, 42

white, 42

Flag, blue, 49

sweet, II, 48

yellow, 49

Flavoring agents, 22

Flax, 2I, 54

Family, 54

New Zealand, 15

seed, 23

Fleabane, 60

Floating-heart, water lily, 57

Flower clusters, 60, 6I

Flowering plants, 32

Flowerless plants, 27-32

Fly poison, 49

Fodder plants, 22

Foods, 20, 25

Food plants, 62

Forsythia, 72

Fossil botany, Museum of, 35-38

Fossils, methods of formation, 38 carbonization, 38

incrustation, 38

petrifaction, 38

Fothergilla, 67

Fountain, 20

Four-o'clock, 5 I

Family, 5 I

Foxglove, 58 purple, $5^{8}$

Fragaria, 53

Frankincense, 23

Fraxinella, 54

Fraxinus, 82 americana, $\mathbf{1 4 5}$

Darlingtonii, 144

Michauxii, 145

nigra, 143

pennsylvanica, 144

Frog-fruit, wedge-leaved, 58

Frostweed, 55

Fruit-bearing plants, 32

Fruit forms, 6o-62

$$
\text { juices, } 23
$$

Frullania, 34

Fruticetum, 3, 63-74

Fumitory Family, 52

Funaria, 3I

Fungi, 27, 28, 30, 33, 34

alga-like, 29

bracket, 29
Fungi, imperfect, 29

parasitic, 29

saprophytic, 29, 30

spore sac, 29

stalk-spored, 29

symbiotic, 29

Fustic, young, 69

Gale, sweet, 64

Galium, 59

Galls, oak, 22

Gamboge Family, 9

Garget, 5x

Gasteria, 7

Gater tree, $7 \mathbf{I}$

Gelsemium sempervirens, $\mathbf{x}$

Gentian, blind, 57

Family, 57

Thibet, 57

Geranium, 54

Family, 54

Gesneria, 10

Gill-over-the-ground, 58

Ginger, 22, 23, 26

Family, 12, 13

plant, 13,22

wild, 23,50

short-lobed, 50

Shuttleworth's, 50

Ginkgo biloba, 46

Ginseng, 56 Family, ro, 56, 71, 22

Gleditsia, 80 triacanthos, 134

Globularia, 59 Family, 59

Glossopteris, 37

Glucosides, 24

Goat's-beard, 53

Golden bell, 72

Goldenrod, 60

Gooseberry, 25, 66, 67

Family, 66

Goosefoot Family, 5o

Gossypium, 21

Gourd, 63 Family, 63

Grain-of-Paradise, 26

Grains, 24

Grape, 63

Family, 63

Oregon, 66

Graphite, 36

Grass, 10, 22, 48

blue, 48

cloth, Io

Family, 4, ro, 48

Japanese plume, 48

orchard, 48 
Grass, red-top, 48 reed canary, 48 rib, 59 variegated, 48

ribbon, 48 sweet vernal, 48 sour, 54 tall fescue, 48 timothy, 48

Grevillea, I4

Green-brier, 62 -felt, 28 -slime, 28

Ground ivy, 58

Groundsel bush, 74

Guides, 88

Gulf weed, 28

Gum, chewing, 22 chicle, 22 sapodilla, 22 sour, 142 spruce, 95 sweet, 79,125

Gums, 20

Gum trees, I5

Gutta percha, 2I

Gymnosperms, 32, 36

Gypsophils, 5I

Hackberry, 78, 122 rough-leaved, 122 southern, 78

Haematoxylon campechianum, 9

Hakea, 14

Hardhack, 26, 67

Haw, black, 73, 147 red, 13 I

Hawthorn, 68, 79 English, 129

Hawk-weed, 60

Haworthia, 7

Hazel-nut, 65 beaked, 65 European, 65

Heartsease, 26

Heath Family, 7x

Hedge nettle, 58

Heliconia, $\mathbf{3} 3$

Hemlock, 22, 23, 83, 95

Carolina, $4 \mathbf{I}$

forest, 40,8$\}-85$

ground, 45

grove, $3,4 \mathrm{I}, 83,95$

spruce, $4 \mathrm{I}, 83,95$

Canadian, 4I, 83

Carolina, 3, 4I

Japanese, 4I

Hemp, $2 \mathrm{I}$

bowstring, 5
Hemp, Manila, I2

Sisal, 8

Henbane, 26

Hepatics, 30, $3 \mathbf{I}$

Herbaceous grounds, 3, 46-63

economic collection, 62 morphological garden, $60,6 I$ systematic plantation, 47-60 viticetum, 62, 63

Herbarium, 39

Hercules club, r4r

Hibiscus syriacus; 70

Hickory, 83, 103-105

mocker-nut, ro3

pignut, 105

shagbark, 103, I05

shellbark, 104

small-fruited, ro5

swamp, 76

water, 76

Hickory nut, 25 common, 104

Hicoria alba, 103

glabra, ro5

cordiformis, 104

microcarpa, 105

ovata, 104

Pecan, 76

Hoffmania, ro

Holly, American, 69, 136

crenate, 69

European, 69

Family, 69

serrate, 69

Hollyhock, 55

Honey locust, 80, r34, I35

Honeysuckle, 59, 63, 73

blue fly-, 73

bush, 73

Family, 59, 63, 72

fragrant, 73

golden-veined, 73

Morrow's, 73

narrow-leaved Albert, 73

Standish's, 73

Hops, 26

Horse-balm, 58

Horse chestnut, 26, 7o, 8I

Horseradish, 25

Horsetail, 31, 32, 34

Horticultural Society, 39

exhibits, 39

meetings, 39

Hornbeam, 76, ro6

American, 76, 106, 107

hop-, 76, 106

Japanese, 76

Hornwort Family, 52

Hound's tree, $7 \mathbf{I}$ 


\section{( 156 )}

House-leek, 8, 53

Huariqui, 8

Huckleberry, 72

Hudson River Valley, Native Trees of the, 90

Humble plant, 9

Hyacinth, grape, 49

blue, 49

water, II

Hybrids, $6 x$

Hydrangea, 66

Family, 63, 66

hortensis, 15

large-flowered, 66

oak-leaved, 66

Hydroid, 36

Hydrophyllum, 57

Hymenocallis, 5 caribaea, 5

Hypericum, 70

Hyssop, 58

Ibervillea sonorae, 8

Iceland moss, 25

Ilex opaca, 136

Indian root, 56

India rubber, $2 x$

articles manufactured from, 2 I instruments for collecting, $2 \mathrm{r}$ sources of, 21

Indigo, 22 false, 68

Innocence, 59

Insectivorous plants, I4

Insect powder, 23

Ipecac, 26

American, 26

Iraga boku, 45

Iris, 87

Family, 49

German, 49

Japanese, 49

Siberian, 49

Irish moss, 25

Isoetes, $3 \mathbf{I}$

Ivy, ground, 58 Japanese, 63 poison, 69

Ixora, ro

Jack-in-the-pulpit, $\mathbf{x}, 48$

Jacob's ladder, 57

Jamestown weed, 58

Jatropa Curcas, ro

Jessamine, night-blooming, 7 yellow, 16

Jewel-weed, 55

Family, 55

Jimson weed, 58
Judas tree, American, 68 Asiatic, 68

Juglans, 75 cinerea, 102 nigra, 103

Juices, fruit, 23

Jujube tree, 70

Juniper, 45, 64, 96, 97

Chinese, 46

common, 45

Irish, 45

low, 97

prostrate, 46

Savin, 45

Juniperus, 45

communis, 97

nana, 97

var. pyramidalis, 46

Jute, 2 I

virginiana, 96

Kaffir bread, 18

Kaffir's head, 18

Kagoma utsugi, 67

Karamume, 66

Katzoura, 65

Kelp, great, 28

King nut, 76

King's sword, 49

Kinnikinnik, 7 $\mathbf{I}$

Knotweed, 50

Japanese, 50

Sakhalin, 50

Laboratories, 39

Lactuca, 60

I.ady's mantle, 53

Lamb's quarters, 50

Lantern Slides, 39

Larch, 44, 94

American 94

Chinese, 45

European, 44

golden, 45

Japanese, 44

Larix, 44 laricina, 94

Larkspur, 52

Laurel, 26

cherry, 26

Family, 66, 79

Lavender, sea, 56

Lead, black, 36

Leaf forms, 60

aquatic, $6 \mathrm{r}$ compound, $6 \mathrm{x}$ insertion, $60,6 \mathrm{x}$ margins, $60,6 \mathrm{I}$ mosaic, $6 \mathbf{x}$ 


\section{( 157 )}

Leaf movements, 60 position, 6I simple, 60 venation, $60,6 \mathrm{I}$

Leatherwood, $7 \mathbf{I}$

Lectures, 38 hall, 38 public, 38 school, 38

Lemna, 48

Lemon, 14, 23, 54, 69

Lepidodendron, 36, 39

Leptobryum, $3 \mathrm{I}$

Lettuce, 25,60 water, II

Library, 39

Lichens, 27, 29, 30, 34

Licorice, 22 plant, 22

Lignite, 38

Lilac, 23, 72

Himalayan, 72

Pekin, 72

Rouen, 72

Lilium, 49

Lily, 49

blackberry, 50
calla, ri

day, 49 yellow, 49

Family, 5, 8, 14, 49

lemon, 49

plantain, 49

pond, large-yellow, 5I red-disked, $5 \mathrm{I}$

true, 49

Lily-of-the-valley, 49

Family, 49

Linden, 26, $14 \mathrm{I}$

American, 82, I4I

cordate, 82

Family, 82

flowers, 26

Japanese toad-, 49

silver, 82

white, 82

Linen, 21, 54

Linseed oil, 23

Linum, 54

Lippia, 58

Liquidambar, 79

Styracifua, 125

Liriodendron Tulipifera, 123

Liver-leaf, 52

Liverwort, 34

Lizard's tail, 50

Family, 50

Loasa Family, 13

Lobelia Family, 6o
Local flora, 3 :

Location, I

Locust, 135

bristly, 68

clammy, 135

honey, 80, 134, 135

Japanese, 80

tree, 80

Lodoicea maldivica, 17

Logania Family, 72

Logwood, 22

tree, 9

Loosestrife, clethra-like, 56

Family, 55, 56

fringed, 56

purple, 55

swamp, 55

Lopseed, 59 Family, 59

Lorillard Mansion, 3, 77, 83, 84

Lovage, 23, 56

Lycopodium, 3 I

Lycopods, $3 \mathbf{I}$

Maackia, 80

Mace, 22

Madder, 22

Family, 10, 59

Madeira nut, 76

Magnolia, 50, 123

Family, 66, 79

Fraser's, 79

virginiana, 123

Maguey, 5

Mahogany Family, 8o tree, 9,80

Mahonia, 65, 66 Japanese, 66

Maiden-hair tree, 46 Family, 46

Malus, 79 coronaria, 126

Mallow, 55

crimson-eye, 55

Family, 55, 70

marsh, 55

rose, 87 swamp, 55

Mammee-apple, 9

Mandrake, 26, 52

Mangrove, 22

Man-in-the-ground, 26

Maple, 25, 70, 8I, 137-140 ash-leaved, 8I, I40

black, 139, 140

European, 8I

Family, 70, 8x

Ginnala, 70

goosefoot, 8 I 
Maple, mountain, 137,138

Norway, 140

red, $81,83,106,138$

rock, $8 \mathbf{r}$

scarlet, $\mathbf{1} 39$

silver, $x=8$

striped, 81,137

sugar, 25, 81. I 39, I40

swamp, I39

sycamore, $8 \mathrm{I}$

white-barked, $8 \mathrm{I}$

Marshmallow, 26

Mastic, 23

Masticatories, 22

Maté, 23

Matrimony vine, 72

Mayapple, 52

Maranta arundinacea, 5

Marigold, 26

fig-, 7,5 I

Meadow beauty, 55

Family, 56

-rue, 52

-sweet, willow-leaved, 67

Means of access, I

Medicinal plants, 62

Medusa, 9 Philippine, 9

Meetings, 39

Horticultural Society, 39

Torrey Botanical Club, 39

Mesembryanthemum, $5 \mathrm{I}$

Mezereon Family, 13, 7I

Micorhiza, 29

Microscopes, collection of, 39 exhibit, 32

Mignonette Family, 52 white cut-leaved, 52 yellow cut-leaved, 52

Mildew, 29

Milfoil, 26, 56

Milkweed, 7, 57

common, 57

Family, 57

hairy, 57

swamp, 57

Milkwort Family, 54

Mimosa Family, 9, 21, 53, 54 pudica, 9 resins from, $2 x$

Mint, 22, 58, 59 creeping whorled, 58 curled, 588

Family, 58

pepper-, 23 spear-, 23, 58

Miscellaneous specimens, 23

Mock orange, 66,67

Mocker-nut, ro3, ro4
Moneywort, 56

Monk's hood, 52

Monocotyledons, 5, 32, 47 fossil, 35

Monstera, 6

Moon flower, 63

Moonseed, Canada, 63 Family, 63

Moosewood, 7r, 8I

Morel, 25, 29

Morning glory, 63

bush, 57

Family, 57,63

Morphological Garden, 60, 6r

Morus rubra, 122

Moss, 27, 30, 31

black, $3 x$

Florida, I I

Iceland, 25

incrusted, 38

Irish, 25

peat, 31

sea, 33

scale, 30,34

Spanish, $\mathbf{x}$

true, $30,31,34$

Motherwort, 58

Mould, 29

Moutan, 65

Mucillage, 55, 121

Mulberry, 25, 122

Family, 21, 63, 65, 79

resins from, 21

red, $79,122,123$

Tartarian, 65

white, 79, 122

Museum, 2

approach to, 20

botanical, 2, 20

economic botany, 20-26

fossil botany, 35-38

systematic botany, 26-35 local flora, 34, 35

microscope exhibit, 32-34

synoptic collection, 27-32

Mushroom, 25, 29

Muskmelon, 63

Musk root, 23

Mustard, 22, 23, 26

Family, 52

Musa textilis, 12

Myrrh, 23

Family, resins from, $2 \mathbf{I}$

Myrtle Family, 15

Myxomycetes, 27

Nannyberry, $146, x 47$

Narcissus, 49

Neowashingtonia robusta, 16 
Nepenthes, 12

Nettle Family, 5o hedge, $5^{8}$ slender, 50 stinging, 50 -tree, American, 78 wood, 50

Neviusia, 67

Nicotiana, 22

Nightshade, 58

Nine-bark, 67

Nopalea coccinellifera, 8

North meadows, 3, 84, 85

Nut, Barbadoes, Io bitter-, I04 mocker-, 103, 104 physic, ro pig-, ro4

Nutmeg, 22, 23

Nuts, 62

Nyssa sylvatica, I42

Oak, $65,77,83$, II2-120

Alexander's, 117

black, $78, \mathrm{xI}_{3}, \mathrm{II}_{4}$

black-jack, II 5

bur, 77,118

chestnut, II 6, I17 rock, 77, II 7

cork, 24

galls, 22

gland-bearing, 78

gray, II4

iron, 77

Japanese silkworm, 77

large-toothed, 78

laurel, 78

live, II

mossy cup. 77

pinnatifid-leaved, 77

post, 77, II $9, \mathbf{2} 20$

red, 77, II 2, II 5

Schnecks, 78

scarlet, 78, II 4, II 5

sessile-flowered English, 77

shingle, 78

swamp, 78, II 3

toothed, 77

Turkey, 78

white, 78, I12, I18, II9 swamp, 77, II 8

willow, II6

yellow, II6, II7

Oenothera, 56

Oils, by-products of, 23

fixed, 23

volatile, 23

Olea europaea, 15

Oleander, 15
Oleaster, $7 \mathbf{I}$

Family, 7I

oriental, $7 \mathbf{I}$

Olive, 16,23

Family, 15, 72, 82

oil, 23,76

tree, 15,72

Onion, 25, 49

Ooze, 33

Opuntia, 7, 55

Orange, $14,23,25,54,69$

flowers, 26

mock-, 66,67

Osage, 79

trifoliate, 69

Orchid, 13, 14, 50

Family, 16, 17

Ordinances, city, 88,89

Orpine Family, 52, 53

Orris root, 23

Ostrya virginiana, I06

Oswego tea, 58

Oyster plant, 60

Pachysandra, trailing, 54 terminal, 55

Padus virginiana, I 34

Paeonia, 52

Paeony, 52, 87 moutan, 65 tree, 65

Palm, 4, 5, 16, 17, 24, 25 cocoanut, 4,25

$$
\text { double, } 17
$$

corozo, 4

date, 4

fan, 16

Chinese, 4

royal, 4

sago, 18,24 fossil, 37

silver-top, 4

sugar, 25

Palmetto, 16

saw, 22, 26

Panama hat plant, 4

Papaya, 6

Papaw, 6

Paper, 24, 25, 96

plant, Egyptian, ro

pulp, 94, 95, Ior, I40, I4 I

straw, 25

wood and fiber, 21, 24

Parachute flower, I6

Parasites, 60, 6r

Park features, $85-87$

Parrot's feather, II, 56

Parsley, 25

Parsnip, 56 


\section{( I6o )}

Parsnip, golden meadow-, 56

Paths, 85

Paulownia, 82

Pea, 54, 63

Family, 54, 63, 68, 80

tree, 68

Chamelegro, 68

common, 68

pigmy, 68

small-leaved, 68

Peach, 26, 68

dwarf, 68

three-lobed, 68

Peanut, 25

Pear, 68

Peat moss, $3 \mathbf{I}$

Pecan nut, 76

Pedicellaria, showy, 52

Pelargonium, 54

Pennyroyal, 23, 26

Pencil tree, 74

Pepper, 23

black, 22

Pepperidge, I 42

Peppermint, 23

Pereskia, 7

Persimmon, 82, 143

Philadelphus, 66

Philippine Medusa, 9

Philodendron, 6, II, 80

Phlox, 87

Britton's, 57

Family, 57,58

garden, 57

ground, 57

white-flowered, 57

hairy, 57

Phoenix dactylifera, 4

Phoenicophorium sechellarum, 4

Phormium tenax, 15

Physic nut, xo

Phytolacca, $5 \mathbf{I}$

Phytopsis, 36

Picea, 42

mariana, 94

rubens, 94

Pickerel weed, 49

Family, 49

Pie plant, 50

Pieris, Japanese, $7 \mathrm{I}$

Pignut, 76, 104-106

Pigweed, 51

Pine, I4, 21, 22, 23, 40, 43, 64, 91-93, 95

Austrian, 44

Bank's, 43

bull, 44

Canadian, 44

Cembra, 43
Pine, Corean, 43

Corsican, 43

Family, 13-r 5, 64 resins from, 21

Himalayan, 43

jack, 43

Japanese black, 44 red, 43

Jersey, 92

long-leaf, 2r

long-leaved, 92

Macedonia, 43

Norfolk Island, 14

pitch, 91

red, 44,93

Scotch, 44

variegated, 43

screw, 6

scrub, 92, 93

short-leaved, 92

small-flowered, 44

Swiss stone-, 43

Table mountain, 44

Tyrolese mountain-, 43

umbrella, 44

white, 43, 90, 93

yellow, 44

Pineapple, 6, II, I2

Family, 9, 11, 12

Pines, 6

Pinetum, 3, 40

Pink, 5 I

Family, 5I

swamp, 49

Pinus, 43

echinata, 92

resinosa, 93

rigida, $9 \mathbf{1}$

Strobus, 90

virginiana, 92

Pipewort Family, 49

Pitch, Burgundy, 42

Pitcher plants, 14

East Indian, 12

Plan, general, 2

Plantain, 12

Family, 59

lily, 49

Rugel's, 59

wild, 13

Plane tree, 79

American, 79

Oriental, 79

Plant constituents, 24

Platanus occidentalis, 125

Plum, 68, 132, 133

date, 82

garden, $\mathbf{r}_{32}$

Family, 64, 68, 79, 80 
Plum, wild yellow, 132

Plumalina, 36

Plumbago Family, 56, 57

Podophyllum, 52

Poke, 25, 5 I root, 26

Pokeweed Family, 5I

Polanisia, 52

Polemonium, 57

Polygonum, 50

Polypody, 34 spores, 34

Pond cypress, 44 lily, red-disked, 5 I yellow, $5 \mathrm{I}$ scums, 28,33

Pond's extract, 67

Pond-weed Family, 48

Pontederia, 49

Poplar, 24, 74, 75, 85, 98-100 balm of Gilead, 99 balsam, 99

black, 99

Bolle's, 75

Carolina, 74, 75, 100

Italian, 75

Lombardy, 75, I00

necklace, roo

silver-leaf, 75

Simon's, 74, 75

swamp, 98

white, 75

Wobst's, 74

yellow, 79

Poppy, 26

Family, 52

Mexican, 52

oriental, 52

water, II, 48

Populus, 74

balsamifera, 99

candicans, 99

deltoides, 100

grandidentata, ror

heterophylla, 98

italica, 100

Porter, 23

tremuloides, 100

Portulaca, 5I

Potato, 24, 25, 58

Family, ro, 58, 72

flour, 24

sweet, 24, 25

Power house, 19

Prickly pear, 55 eastern, 55

Primrose, 56

European, 56

Family, 56
Primula, 56

Privet, 72

California, 72

Propagation, forms of, 60, 6I

Prunus americana, $\mathbf{1}_{32}$ Avium, $\mathbf{1 3 3}$

domestica, $\mathrm{x}_{32}$

pennsylvanica, 133

Pseudolarix, 44

Pseudotsuga mucronata, 40

Ptelea trifoliata, 68

Pteridophytes, 27, 31, 35, 36

Puffball, 29

Pulp, 94, 95, ror, 140, 14:

Pulque, 8

Purposes, 2

Purslane, 5 I

Family, 5I

Pusley, 5I

Quaker-lady, 67

Quassia, 26

Queen's root, 26

Quercus, 77

alba, II 9

Alexanderi, 117

borealis, II4

bicolor, 118

coccinea, $\mathrm{II}_{4}$

macrocarpa, $\mathbf{1 1 8}$

marilandica, II 5

Muhlenbergii, II 6

palustris, $\mathrm{II}_{3}$

Phellos, II 6

Prinus, II7

rubra, 112

stellata, $\mathbf{1} \mathbf{9}$

velutina, II 3

Quillworts, 3r

Quince, 68

Ragweed, 6o

Family, 60

giant, 60

Ramie plant, ro

Raspberry, 53, 67 purple-flowered, 67

Rattlesnake-master, 56

Red root, 70 top, 48

Reeds, incrusted, 38

Reseda, 52

Resins, 20-23, 43

Resinoids, 24

Retinospora, 45

Rhabdocarpon, 36

Rhododendron, $7 x$

Rhubarb, 26, 50 
Rhus glabra, 136

$$
\text { hirta, } 135
$$

Rib-grass, 59

Rice, 25

River woods, $3,84,85$

Roads, 85

Robinia, 80

$$
\text { Pseudacacia, } 135
$$$$
\text { viscosa, } \times 35
$$

Rock cress, Alpine, 52 -rose, 55

Family, 55

Rodgersia, 53

Rondeletia, 10

Roots, aquatic, 6I

Rope, 2I

Rose, 53, 67

box, 68

Cherokee, 15

climbing, 63

dog, 67

Family, 53, 63, 67, 68

hips, 26

Japanese, 67

pasture, 67

red-leaved, 67

of Sharon, 70

Watson's, 67

Rosemary, 16

Rubber, 2 I plant, 6

Rubus, 67

Rue, 54 Family, 14, 54, 69, 80 meadow-, 52

Ruellia, hairy, 59

Rumex, 50

Rush, common bog, 49 common wood, 49

Family, 49

slender, 49

Rusts, 29

Rye, 24

Sabal Palmetto, I6

Saccharum, 25 officinarum, xo

St. Johnswort, 70

Family, 55

Safflower, 26

Sage, 22, 58

Sagittaria, 48

Sago, 24

flour, 24

palm, $x 8,36,37$

starch, 18

Sahuaro, 9

Salicetum, 74

Salix, 74
Salix alba, ro2 babylonica, 102 nigra, IоI

Salvinia, II

Sambucus, 73

Sandalwood, 23, 26

Sandzaki, $7 \mathbf{I}$

Sansevieria, 5

Sap green, 70

Sapodilla, 22

Family, 2r

gum, 22

Sargasso weed, 28

Sargassum, 28

Sarracenia, 14

Sarsaparilla, 26

Sassafras, 23, 26, 79, 124 medulla, 26

oil of, 124

Sassafras, 124

Saururus, 5C

Saxifrage Family, 53 heart-leaved, 53

Menzie's, 53

shield-leaf, 53

Scale moss, 30

Scolithus, 36

Screens, border, 87

Screw-pine, 6

Scythian lamb, 19

Sea lavender, 56 moss, 33

Seaweeds, 27, 28, 33

brown, 28

fossil, 36

green, 28

red, 28

Sedge, I0, 22, 48

cat-tail, 48

Family, ro, 48

fox, 48

Fraser's, 48

Gray's, 48

tussock, 48

Sedum, 53

Seed-bearing plants, 32, 47 dispersal, 6o, 6r plants, fossil, 36, 37

Seedless plants, 47

Sempervivum, 8, 53

Senega, 26

Senna, 26, 54

American, 54

bladder, 68

Family, 9, 54, 64, 68, 80

scorpion, 69

Sensitive plant, 9

Serviceberry, 68, 127, 128 swamp, 128 


\section{( I63)}

Shadbush, 68

Shagbark, 76, I03, ro4

Shellbark, 104

Shrubs, collection of, 63-74

Skunk cabbage, I I, 48

Sigillaria, 36, 37

Silicified wood, 38

Silkworms, 77

Silver fir, 42

Japanese, $4 \mathrm{r}$

Nordmann's, 42

Sicilian, 42

Veitch's, 42

Siroyama buki, 67

Sisal, \&

Slime moulds, 27, 32, 33

Sloe, 73

Smilax Family, 62, 63

Smoke tree, American, 69 European, 69

Smuts, 29

Snake-head, Lyon's, 58

Snakeroot, Canada, 26

Sneezeweed, 60

Snowball, Japanese, 73

Snowberry, 73

Snowflake, water, II, 57

Soap, 23

Soapberry Family, 70

Soapwort, 26

Solanum, 58

Solomon's seal, 49

Sorbus americana, I26

Sorrel, wood, 54

3our grass, 54 gum, I42 sop, 9

Spatterdock, 5I

Spearmint, 23, 58

Species, 6r

Speedwell, 58 gentian, 58 long-leaved, 58

Spermatophyta, 32

Spice bush, 66

Spices, 22

Spider lily, 5

Spiderwort, 49

Family, 49

Spikenard, wild, 49

Spinach, 25

Spindle tree, Bunge's, 69 winged, 69

Spiraea, 67 Thunberg's, 67

Sphagnum, 3 I

Spleenwort, 47

Spruce, 23, 24. 4I-43, 94, 95 blue, 42
Spruce, Coloradio, 42

Engelmann's, 42

gum, 95

hemlock, 4I, 83, 95

Canadian, $4 \mathrm{I}, 83$

Carolina, $3,4 \mathrm{r}$

Japanese, 4I

Norway, 42

oriental, 42

red, 94,95

Servian, 42

swamp, 94

tiger's-tail, 42

white, 42

Yesso, 42

Spurge, cypress, 54

Family, 9, Io, 21, 54

flowering, 54

Squash, 63

Staff-tree, European, 69

Family, 63, 69

Stagger-bush, 72

Stangeria, 37

eriopus, 18

Stapelia, 7

Staphylea, 70

Star anise, 26

Starch, II, I8, 24

arrowroot, 24

banana, 24

cassava, 24

chocolate seeds, 24

coontie, 24

corn, 24

grains, 24

palm, 24 sago, 24

potato, 24 sweet, 24

rye, 24

sago palm, 24

sweet potato, 24

wheat, 24

Starwort, water, 54

Statice, 56

Steeple-bush, 67

Stem forms, 6o, $6 \mathrm{I}$

aquatic, $6 \mathrm{I}$ root climbing, $6 \mathrm{I}$

tendril climbing, $6 \mathbf{r}$

tree climbing, $6 \mathbf{r}$

twining, $6 \mathrm{r}$

Stigmaria, 37

Stinkhorn, 29

Stonecrop, 8, 53

Family, 8, 52

great, 53 purple, 53

mossy, 53 
Stonecrop, Nevius', 53 poplar-leaved, 53

Siberian, 53

Siebold's, 53

white, 53

wild, 53

Stonewort, 26, 28

Storax Family, 72

Strawberry, 53

shrub, 66 Family, 66

Strelitzia, $\mathbf{1 3}$

Stuartia, 70

Sugar, II, 20, 25, 103

beet, 25

-berry, 78

cane, ro, 25

maple, 25, 8I, I39, 140

palm, 25

palm, 25

sources of, 25

Sumac, 22, 135, 136

Family, 2r, 69

resins from, $2 x$

fragrant, 69

mountain, 69

Osbeck's, 69

scarlet, $69,1_{3} 6$

smooth, 69

staghorn, 135, I36

Sundew, 14, 26

Sunflower, 60, 87

Sunplant, 5 I

Swallowwort, 57

Swamp pink, 49

Sweet bay, 123

brier, 67

fern, 64

flag, $\mathrm{II}, 48$

gall, 64

gum, 79, I25

pepper bush, North American, 72

$$
\text { Japanese, } 7 \mathbf{I}
$$

potato, 24, 25

flour, 24

Swietienia Mahagoni, 9

Sycamore, 126

Symphoricarpos, 73

Synoptic collection, 27-32

Syringa, 66, 72

Syrup, maple, 8I, I39

Systematic Botany, Museum of, 26

Systematic plantations, $47-60$

Tail flower, 6, II

Veitch's, 6

Talinum, small-flowered, $5 \mathrm{I}$

Tamarack, 94

Tamarind, 7,26
Tamarindus indica, 9

Tamarix, 71

Family, 7I

Tanner's tree, 69

Family, 69

Tannin, Ior, 136

Tanning materials, 22, 95, II 2, II 4 refuse, 22

Tansy, 23, 26; 60

Tanks for water plants, 17

Tape-grass Family, 48

Tapioca, 24

Tara, II

Taxaceae, 44

Taxus, 45

Taxodium, 44

Tea, 1 5, 23, 70

Family, 70

New Jersey, 23, 70

Oswego, $5^{8}$

Paraguay, 23

Teasel, 59

Family, 59, 6o

Tendril-climbing stem, $6 \mathrm{I}$

Thallophyta, 27, 35

Thea sinensis, 15

Theobroma, 23 Cacao, 6

Thistle, 60

Family, 13, 16, 6o, 64, 73

Thorn, 79, $128-\mathbf{r}_{31}$

apple, 68

Brainerd's, 131

cock-spur, 128, 129

large-fruited, 129

long-spined, I3 I

Pringle's, I30, I3 I

red-fruited, I3 I

round-leaved, 129

thin-leaved, 130

twin-mountain, 130

waxy, 129

Washington, 79

Thrift, 56

Thuja, 46

occidentalis, 97

Thyme, 22

Tick-seeds, 60 -trefoil, 54

Timothy, 48

Toad-lily, Japanese, 49

Tobacco, 22, 58

Tomato, 25, 58

Tonka bean, 22, 26

Torrey Botanical Club, 39

Touch-me-not, 55

Toxylon, 79

Traveler's tree, I3

Tree of Heaven, 80 
Tree of life, 97

Trees of the Hudson River Valley,

Native, 90

Trefoil, shrub, 69

$$
\text { tick-, } 54
$$

Trichosporum, 10

Trigonocarpon, 36

Tropical plants, 6, 9, II, 12

Truffle, 25, 29

Trumpet creeper, 63 Family, 63, 82

Tsuga, $4 \mathrm{I}$ canadensis, 4I, 95 caroliniana, $4 \mathrm{I}$

Tufa, calcareous, $3 \mathbf{I}$

Tulip tree, $79,83,123,124$

Tumion taxifolium, $\mathbf{I}_{4}$

Tupelo, 142

Turkey beard, 49

Turpentine, 21, 43, 92

Twine, $2 \mathrm{I}$

Twining stem, $6 \mathbf{x}$

Twin-leaf, 52

Ulmus, 78 americana, 120 campestris, I2I fulva, 120 Thomasi, I2I

Umbrellaworts, 5 I

Unicorn-plant, $5^{8}$ Family, $5^{8}$

Valerian, 59 Family, 59

Vanilla bean, 22

Variety, 6r

Vegetables, 62

Vetch, 54

Veronica, 58

Vervain, 58 Family, 57, 72

Viburnum, 72, 73, 146, 147 Chinese, 73

Lentago, 146 prunifolium, 147

Siebold's, 73

sweet, 126

woody, 73

Vines, 62

Violet, African, Io Family, 55, 56 Usambara, ro

Virginia creeper, 63 -willow Family, 66

Viticetum, 62, 63

Wahoo, 78

Walnut, 25, 75, 103
Walnut, black, $76, \cdot$ I03

English, 75

Family, 77

oil, 76

Water-hyacinth, II, 49 blue, 49

elm, 78

lily, II, I7

Cape Cod, $5 \mathrm{I}$

European, 51

Family, $5 \mathbf{I}$

floating-heart, 57

pink, 5 I

royal, $\mathbf{1} 7$

small white, $5 \mathrm{I}$

sweet-scented, 5 I

Waterleaf, broad-leaved, 57

Family, 57

purple, 57

Virginia, 57

Watermelon, 63

Water-milfoil, Chilian, 56

Family, $5^{6}$

-plantain, 48

Family, 48

-poppy, II, 48 Family, 48

-shield, 5 I

-starwort Family, -

-snowflake, II, 57

-target, $5 \mathrm{I}$

Waxberry, 64

Wayfaring tree, 73

Weigela, 73

Wheat, 24

White deal, 42

White wood, 79, 82

Wig tree, 69

Wild brier, 67

Willow, 64, 65, 74, 75, 85, тох, х16

black, 74 , IOI, IO2

Bashford's, 74

Family, 64, 75

golden, 74,75

Napoleon's, 75

purple, 74

Ural purple, 74

Virginia, 66

weeping, 74, 75, 102

white, ro2

yellow, 74 red-stemmed, 74

Willow herb, 55

Wine, 23

-berry, Japanese, 67

Wing nut, narrow-winged, 75 Rhoeas-leaved, 75

Winterberry, Virginia, 69

Wintergreen, 23, 25 


\section{(166)}

Wistaria, 63

Witch hazel, 66 Family, 66, 79

Withe-rod, 73 larger, 73

Wood, 20, 26 carbonized, 38 crude products of, 26 fiber, 24 silicified, 38 specimens, 26

Woodbine, 63

Wood-sorrel Family, 54, 55

Wormseed, 23

Wormwood, 6o, 74

Xanthorrhiza, 65

Yama doosin, 67

Yam Family, 62
Yantias, II

Yarrow, 60

Yeast, 29

Yellow-eyed-grass Family, 49 root, 65 wood, Amur, 8o

Yew, 45

American, 45

cluster-flowered, 45

Fortune's, 45

English, 45

Family, 13, 14, 44, 4\%

Japanese, 45

Young fustic, 69

Yucca, 8

\section{Zamia, 18}

Zantedeschia aethiopica, II

Zingiber Zingiber, 13 


New York Botanical/Descr

Work Botanical/Descriptive quide to

35185001149242 

